\title{
Savannah River Site Interim Waste Management Program Plan FY 1991-1992 (U)
}

May 1992

Prepared by

High-Level Waste Management Department Control Management

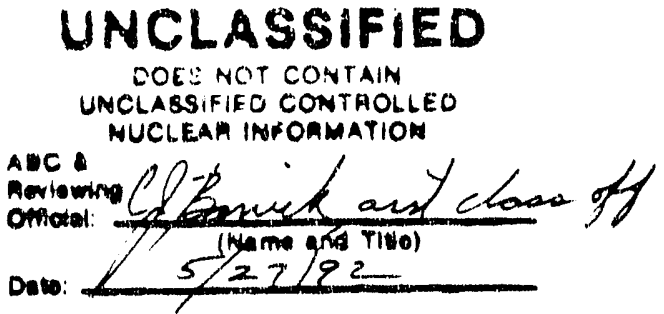




\section{DISCLAIMER}

This report was prepared as an account of work sponsored by an agency of the United States Government. Neither the United States Government nor any agency thereof, nor any of their employees, makes any warranty, express or implied, or assumes any legal liability or responsibility for the accuracy, completeness, or usefulness of any information, apparatus, product, or process disclosed, or represents that its use would not infringe privately owned rights. Reference herein to any specific commercial product, process, or service by the trade name, trademark, manufacturer, or othenwise, does not necessarily constitute or imply its endorsement, recommendation, or favoring by the United States Government or any agency thereof. The vieus and opinions of authors expressed herein do not necessarily state or reflect those of the United States Government or any agency thereof. 


\section{CONTENTS}

Page

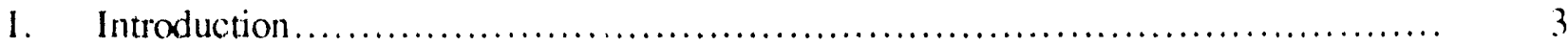

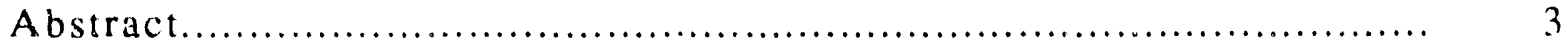

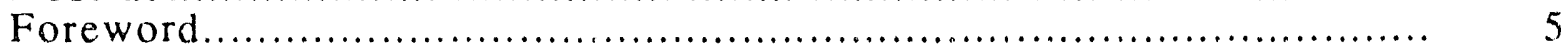

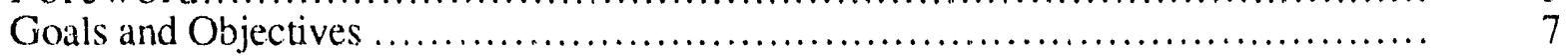

II. General Site Information. .................................................. 11

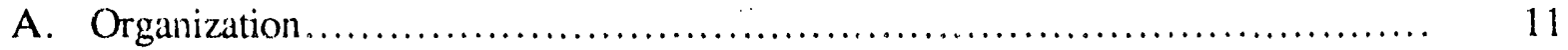

1.0 Site: Department of Energy ....................................... 11

SR Field Office Responsibilities .................................... 11

2.0 SRS Contractor Organizations ..................................... 16

Geographic Size..................................................... 16

Locations and Descriptions of Installations............................ 16

General Counsel Division ........................................... 19

Public Relations Division............................................ 21

Human Resources Division ......................................... 21

Financial Management and Information Systems Division ............... 21

Administrative Services Division ..................................... 21

Site Services Division .............................................. 21

Special Projects Division .......................................... 21

Reactor Restart Division ......................................... $\quad 22$

Nuclear Materials Processing Division..................................... 22

Waste Management and Environmental Restoration Division............. 23

Savannah River Laboratory ....................................... 24

Engineering and Projects Division..................................... 25

Environment, Safety, Health, and Quality Assurance Division............. 26

New Production Reactor Program....................................... 26

3.() Lead Responsibility for Waste Management Activities.................... 27

Waste Management Technology ...................................... 27

Waste Management Operations............................................ 27

Waste Management Works Engineering ............................... 27

Waste Management Program Control and Integration...................... 29

Waste Management Programs--Quality ................................. 29

Waste Minimization................................................. 29

B. Identification of Waste Management Facilities ............................. 29

1.0) Identification and Location of Facilities .............................. 29 
A. High Level Waste

1.0 Overview.

High-Level Waste Inventory

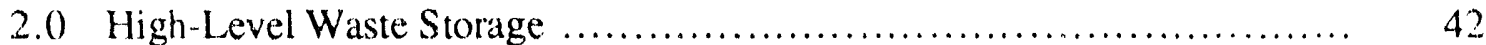

Waste Tanks.................................................... 42

Technical Approach to Leaks in Waste Tanks.......................... 42

3.0 Description of High-Level Waste Treatment Facilities ..................... 44

Tank Farm Evaporators .............................................. 44

Cesium Removal Columns ......................................... 44

4.0 High-Level Waste Transfer and Processing .......................... 48

Salt Processing ..................................................... 48

Sludge Processing ................................................. 51

Annulus Cleaning and Zeolite Removal .............................. $5 . \quad 5$

Implementation of Waste Transfer and Processing ..................... 5.3

5.0 Current and Future Plans

Replacement of the HLW Evaporator

Tank Farm Control Systems and New Control Room Plan

H-Area Division Box 7 (HDB-7) Containment Building ................ 55

New Waste Transfer Facility (NWTF) ............................. 55

B. Transuranic Waste................................................. 58

1.() Overview...................................................... 58

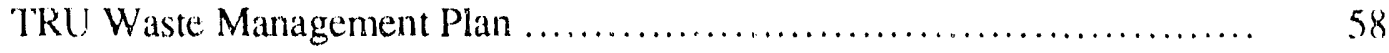

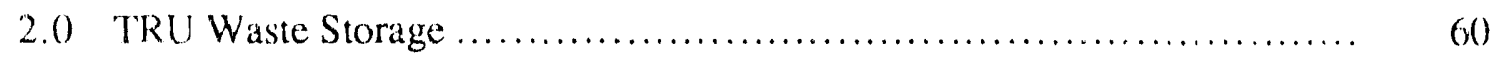

3.0 TRU Waste Treatment.............................................

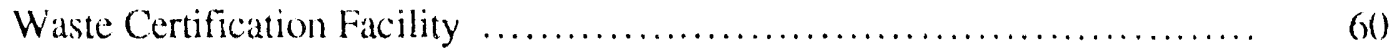

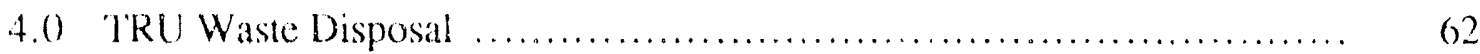

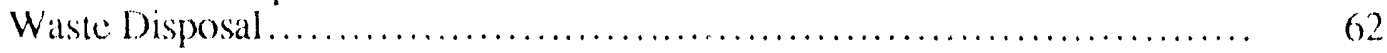

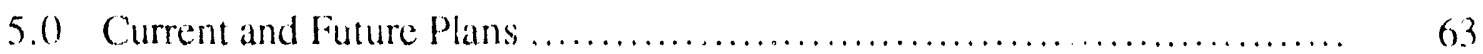

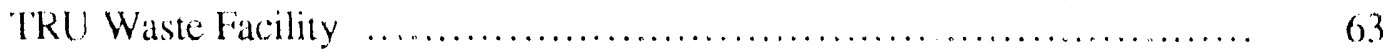

Alternative TRU Waste Processing Facility ............................ 64 
III. Radioactive and Mixed Waste Management (Cont'd)

C. Low-Level Liquid Waste .......................................... 64

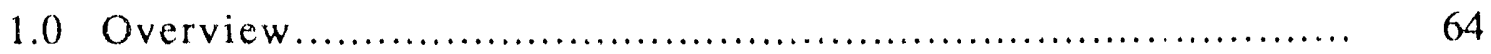

2.0 Low-Level Waste Storage ..................................... 64

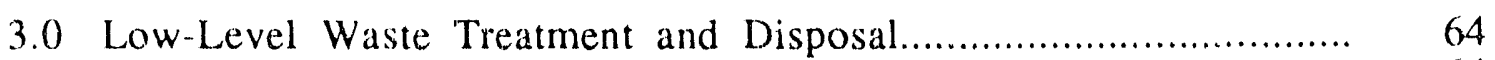

Low-Level Wastes ..................................................... 64

F/H Effluent Treatment Facility .......................................... 69

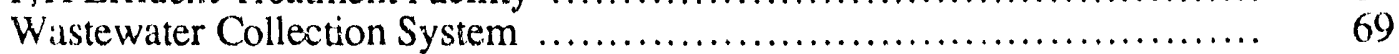

Treatment Facility ...................................................... 70

Interim Contaminated Cooling Water Control.......................... 70

Storm Water Monitors...............................................

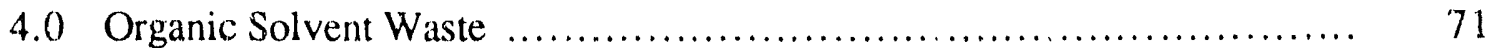

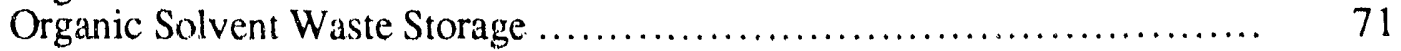

D. Low-Level Solid Waste ............................................. 72

1.0 Overview..................................................... 72

2.0 Low-Level Solid Waste Treatment.................................... 72

Low-Level Waste Compaction ........................................... 75

Landfill Mionitoring Program...................................... 75

3.0 Low-Level Solid Waste Disposal .................................... 75

Solid Waste Disposal Facility ......................................... 75

Rigid Containers for Solid Radioactive Waste ............................ 79

Engineered Low-Level Trench .........................................

Slit Trenches......................................................... 80

Greater Confinement Disposal Vault and Boreholes.......................... 81

Disposal Limits..................................................... 81

Offsite Waste Criteria.............................................. 83

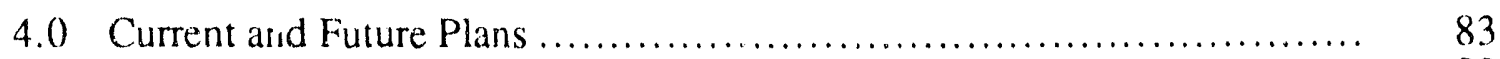

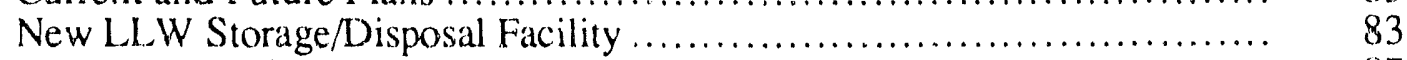

Waste Preparation Facility ............................................. 87

Consolidated Incineration Facility ................................. 87

E. Mixed Solid Waste ............................................... 93

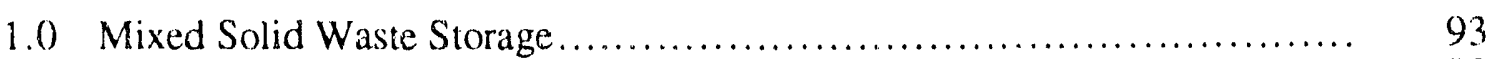

Mixed Waste Storage Buildings 643-29E and 709-2E .................. 93

Mixed Solid Waste Inventory .................................. 93 
IV. Nonradioactive Hazardous Waste ......................................... 99

A. Nonradioactive Hazardous Waste Storage ........................................... 99

1.0 Nonradioactive Hazardous Waste Buildings ........................... 99

2.0 Nonradioactive Hazardous Waste Inventory .......................... $1(0)$

V. Sanitary Waste............................................................... 103

A. Sanitary Waste Landfill ............................................ 103

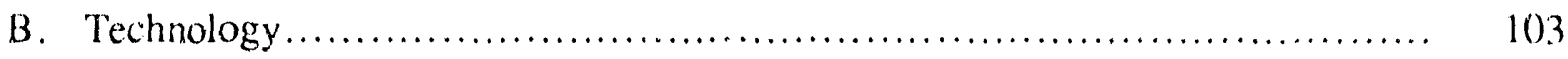

VI. Environmental and Monitoring Programs................................. 107

A. Liquid Radioactive Waste................................................... 107

1.0 Automatic Controls and Alarms ........................................ 107

2.0 Temperature ................................................... 107

3.() Liquid Level Measurement........................................ 107

4.0 Salt and Sludge Level Measurements .............................. 109

5.0 Hydrogen Monitoring.................................................. 109

6.0 Waste Sampling ............................................. 109

7.0 Waste Tank Leak Detection .................................. 110

8.0 Periscope and Direct Photography .............................. 110

9.0 Cooling System Leak Detection ................................. 110

10.0 Offgas Radioactivity Monitors................................... 111

11.0 Collection Sumps on Transfer Lines and Process Cells .................. 111

12.) Surveillance and Monitoring for Contamination ..................... 112

13.0 Radiation Monitors .......................................... 112

14.) Storm Water Monitors .......................................... $\quad 112$

15.0 Monitoring of Groundwater in Waste 'Tank Areas ................... 113

16.0 Dry Monitoring Wells ............................................. $\quad 113$ 
VI. A. Liquid Radioactive Waste (Cont'd)

17.0 Effluent Cooling Water Monitoring $\ldots \ldots \ldots \ldots \ldots \ldots \ldots \ldots \ldots \ldots . \ldots \ldots$

18.0 Realtime Detection Monitoring........................................ 113

19.0 Tritium Stack Monitoring...................................... 113

B. Solid Radioactive Waste ........................................... 117

1.0 Solid Waste Disposal Facility .................................... 117

2.0 Sumps and Rainwater Runoff Ditches ............................. 119

C. Site Administration Limits on Effluents...................................... 119

1.0 Radioactive ...................................................... 119

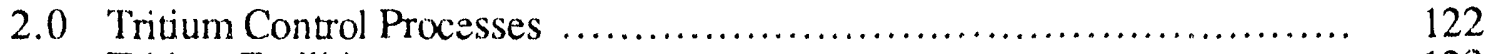

Tritium Facilities .................................................. 123

Replacement Tritium Facility ..................................... 123

Replacement Purification Facility .................................. 123

Storage of Tritiated Oil .............................................. 124

Improved Line Break Procedures........................................ 124

Replacement Tritium Facility ....................................... 124

Extraction of Tritium from Furnaces Directly into Tanks................. 124

Release Controls for Solid Waste..................................... 124

Reactor Facilities.................................................. 125

Moderator Detritiation Plant ................................... 125

400-D Rework Facility........................................ 126

Sealless Pumps .................................................... 126

Basins and Tritiated Groundwater Outcroppings ................... 126

3.0 Monitoring Programs for ETF Effluent .......................... 126

VII. Related Subjects............................................... 131

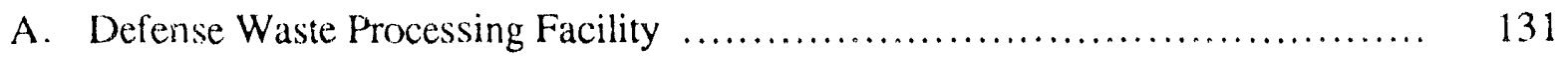

B. Waste Management Personnel Training.................................. 132

Operator Training ....................................................... 132

Mechanical Training .................................................... 134

Supervisory Training................................................... 134

Technical Staff Training ............................................... 134

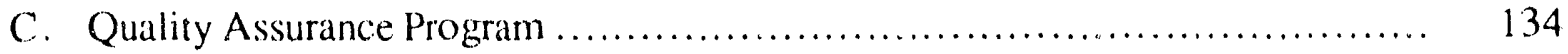

D. Radioactive Waste Documentation System ........................... 135 
VII. Related Subjects (Cont'd)

E. Discussion of Byproduct Ruling....................................... 135

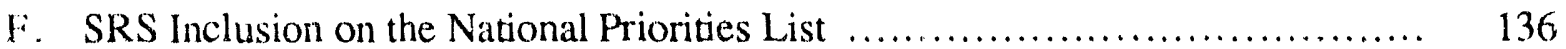

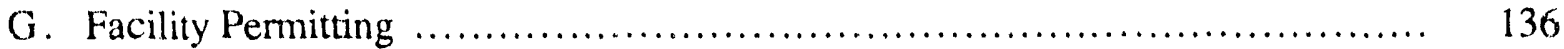

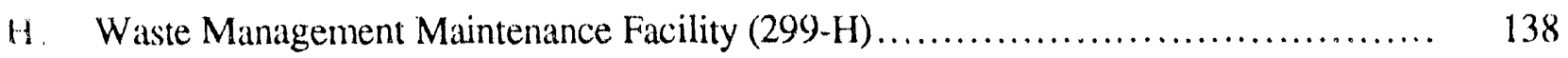

VIII. Appendixes .............................................................. 141

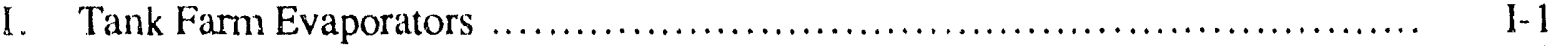

II. Cesium Removal Columns ............................................ II 1

III. Tank Construction and Operating History...................................... III

IV. 1991 Waste Reduction Report .......................................... IV 1 
-

1. INTRODUCTION 
-

BLANK 


\section{INTRODUCTION}

\section{A B S TRACT}

The primary purpose of the Waste Management Program Plan is to provide an annual report of how Waste Management's operations are conducted, what facilities are being used to manage wastes, what forces are acting to change current waste management systems, and what plans are in store for the coming fiscal year. In addition, this document projects activities for several years beyond the coming fiscal year in order to adequately plan for safe handling, storage, and disposal of radioactive wastes generated ai the Savannah River Site and for developing technology for improved management of wastes.

In this document, work descriptions and milestone schedules are current as of December 1991. 
BLANK 


\section{FOREWORD}

The Savannah River Site (SRS) was established in 1950 by the United States Atomic Energy Commission to produce nuclear materials for the national defense. The production of these nuclear materials resulted in radioactive waste byproducts and hazardous waste. As of December 31 , 1991, SRS has stored, in waste tanks, approximately 33.8 million gallons of radioactive high-level waste. This high-level waste (HLW) consists of approximately 3.8 million gallons of sludge, 14.7 million gallons of salt, ${ }^{*}$ and 15.3 million gallons of supernate. The HLW contains approximately 534 megacuries of beta-gamma radioactivity as of December 31, 1991. In addition to the liquid waste, approximately 623 thousand cubic meters of solid waste containing approximately 11 megacuries of radioactivity has been buried or stored in the SRS Solid Waste Disposal Facility. Included in this total is apf soximately 13,000) cubic meters of transuranic waste that contains approximately 850 kilocuries of radioactivity (as generated).

The plant, laboratory, and waste facilities wer: designed, built, and originally operated by E. I. du Pont de Nemours and Company under a contract with the Department of Energy (DOE) (previously the Atomic Energy Commission). Since April 1989, the plant, laboratory, and waste facilities have been managed by Westinghouse Savannah River Company under contract with the Department of Energy.

* The salt results from concentration of alkaline waste at SRS. 
BLANK 


\section{GOALS AND OBJECTIVES}

The goals and objectives of the Savannah River Interim Waste Program are to provide for safe and environmentally acceptable handling, storage, and/or disposal of radioactive, hazardous, and mixed wastes generated at Savannah River (SR) including:

- Development of a Waste Minimization Program that addresses all waste types;

- Storage, processing, and surveillance of high-level liquid waste in underground tanks;

- Conversion of liquid wastes by evaporation to less mobile salt cake;

- Preparation of feed for the Defense Waste Processing Facility (DWPF) by in-tank precipitation and extended sludge processing;

- Continuation of waste removal from Types I, II, and III tanks;

- Development of technology for tank decommissioning;

- Development of technology to redice the risk of radiation exposure and spread of contamination;

- Development of technology for improved management of low-level waste (LLW) to minimize long-term dose to man from disposal;

- Continued sitewide efforts in reduce the volume of waste generation;

- Continued field and laboratory studies designed to improve the model to predict dose-to-man exposure from radionuclides in buried waste;

- Continued demonstration of greater confinement disposal for intermediate-level waste;

- Retrievable storage of transuranic (TRU) waste;

- Continuation of the program to prepare and certify TRU waste so that it meets waste acceptance criteria for the Waste Isolation Pilot Plant (WIPP) in Carlsbad, New Mexico;

- Continuation of subsurface monitoring in and adjacent to waste storage and disposal sites and evaluation of data;

- Continuation of the preparation of applicable permits to comply with state and federal regulatory requirements;

- Development of technologies for treatment and disposal of mixed waste and hazardous waste;

- Implementation of new methods for handling and monitoring of sanitary waste;

- Continuation of the treatment and subsequent disposal of effluent streams; and

- Actively pursuing all aspects of environmental restoration. 
-

BLANK 
II. GENERAL SITE INFORMATION 
BLANK

$-10-$ 


\section{GENERAL SITE INFORMATION}

\section{A. ORGANIZATION}

\subsection{Site: Department of Energy}

\section{SR Field Office Responsibilities}

The U. S. Department of Energy--Savannah River Field Office (DOE-SR) is responsible for coordinating, planning, and directing operations at the Savannah River Site (SRS). DOE-SR oversees day-to-day operations of the facilities at SRS, reviews operating policies and procedures, performs appraisals, and conducts audits. The site is organized into several divisions (Figure II-1).

The Site Specific Plan (SSP) is the responsibility of the DOE-SR. The DOE-SR directs the management and implementation of all environmental restoration, waste management, corrective activities and technology development activities in the plan; and reviews and checks the budget request for Congress to ensure that there is sufficient funding for the SRS to meet its schedules and milestones of the activities in the SSP. DOE-SR also review's and approves all submittals related to environmental activities to agencies and organizations outside of the SRS.

Within the DOE-SR, the environmental restoration, waste management, corrective activities and technology development responsibilities for each organization are as follows:

- The Assistant Manager for Facility Operations (AMFO) organization has primary responsibility for the environmental compliance, operation, and management of the SRS non-reactor facilities.

- The Assistant Manager for Environment, Safety, and Security (AMES\&S) organization is responsible for directing, planning, and coordinating all SRS work related to environmental protection, health protection, safety, and quality assurance. In addition, the AMES\&S organization is providing independent oversight for environmental protection, health protection, safety, and quality assurance to activities in the SSP.

- The Assistant Manager for Engineering and Projects (AMEP) organization is responsible for engineering design and construction of the SRS facilities. It also has primary responsibility for the operation and management of all SRS Power Department facilities such as the powerhouses, sanitary treatment plants, and the Savannah River Laboratory (SRL).

- The Director of the Manufacturing Division, who reports to the AMFO, is primarily responsible for directing and managing the environmental compliance and operation of the Reactor Materials Facilities, Tritium Facility and Naval Fuels Facility.

- The Assistant Manager for Environmental Restoration and Waste Management (AMERWM) has the primary responsibility for directing all work associated with Environmental Restoration and Waste Management activities and implementing and managing the SSP. The AMERWM is also responsible for coordinating the planning, tracking, and reporting of activities for the SSP. 
The AMERWM will ensure the implementation of the SSP by:

- Providing technical oversight and direction to the contractor(s) for waste management planning and operations.

- Reviewing and approving all Environmental Restoration, Waste Management, and Technical Development reports and documents required by DOE-HQ or regulators.

- Coordinating the contractor(s) budget/ program submission to DOE-HQ for the Environmental Restoration and Waste Management operations and Technical Development activities.

- Reviewing detail procedures, policies and practices established by the contractor for compliance with DOE policy, and the safe and environmentally sound operation of the facilities.

- Annually updating the Waste Management plans for all Waste Management activities at SRS.

- Requiring the contractor(s) to perform monthly budget and status reports on all currently funded Waste Management and Environmental Restoration projects and Technical Development activities.

- The Director of the Environmental Restoration Division, reporting to the AMERWM, directs the efforts of the Environmental Restoration Branch and Environmental Compliance Program Management Branch. Responsibilities include planning, coordinating, and directing environmental programs for the Savannah River line and project activities, developing and implementing DOE-SR policies, and evaluating contractor's work.

- The Director of the Waste Operations and Technical (WO\&T) Division, reporting to the AMERWM, plans, coordinates, and directs the overall SRS low-level, transuranic, mixed, and hazardous waste management programs and related technology development program. Other duties include technical support for Environmental, Safety and Health (ES\&H) Activities for all waste management programs. The Division serves as the primary point of contact with DOEHQ for all activities associated with the SSP.

The principal areas of responsibility include:

- SRS Management Programs for low-level waste disposal, the Effluent Treatment Facility (ETF), the Consolidated Incinerator Facility (CIF), Sanitary Landfill Project, Waste Minimization, and the Transuranic Waste Storage and Processing Facility.

- Research and technology development activities in support of SRS, Environmental Restoration, and waste management programs.

- Technical Support in the area of Environmental, Safety, and Health and Quality Assurance for all waste management programs. 
- The Director of the HLW Division, reporting to the AMERWM, directs the efforts of the Defense Waste Processing Facility (DWPF) Branch, the DWPF Compliance Branch, and the HLW Tank Farm Branch. Responsibilities include startup and operation of the DWPF, Saltstone Facility, In-Tank Precipitation (ITP), and F-and H-Area HLW Tank Farms. This Division serves as the primary point of contact with DOE-HQ for all activities associated with HLW Operations at the DOE-SR Field Office.

- The Director of the Environmental Division (ED), reporting to the AMES\&S, oversees SRS compliance with federal and state environmental regulations and agreements and DOE environmental orders and policies; implements the National Environmental Policy Act (NEPA); provides advice and support to the Manager, DOE-SR, and to other DOE-SR Offices and Divisions on implementation of environmental requirements, environmental technology development, and natural resource management; and provides an overview of contractor quality performance of environmental requirements. The ED also coordinates all federal and state environmental regulations, agreements, and permits associated with the SSP and with the Waste Operations Branch (WOB) for planning, reporting, and funding.

ED is composed of two branches, the Environmental Compliance Branch (ECB) and Environmentail Programs Branch (EPB).

The ECB supports SRS operations and projects by the review, approval, and submission of documents related to environmental regulatory compliance (except NEPA) such as permit applications, monitoring reports, and project plans for environmental concerns.

This branch directs the development of engineering and scientific data related to regulatory permit requirements. The ECB conducts its work through implementation of the following seven general program areas:

- Water Supply Program

- Waste Management/Environmental Restoration Program

- Radiological Environmental Program

- Wastewater Management Program

- Air Program

- Environmental Emergency Response Program

- Audits and Appraisal Program

The EPB manages environmental studies and impact mitigation activities to support proposed and ongoing SRS projects. This work covers the following four general areas:

- NEPA Implementation

- Environmental Technology

Development

- Natural Resource Management

- Geoscience Management 
- The Director of the Project Management Division (PMD), reporting to the AMEP, maintains an overview of the total WSRC design and construction effort at SRS and has primary responsibility for interim waste management line item project management. PMD responsibilities include review of projects to ensure that all environmental requirements are fulfilled and appropriate permits are obtained. The PMD Project Management Manual directs staff to ensure that environmental considerations are part of project plans.

- The Office of Chief Counsel (OCC) provides legal advice to the Manager, DOE-SR, and in conjunction with ED, interprets the requirements of environmental laws and regulations as they apply to SRS.

- The Director of the Personnel and Management Evaluation Division (P\&ME), reporting to the Assistant Manager for Administration (AMA), is responsible for maintaining the Recornmendations and Findings Tracking System (RAFTS). This computerized database contains recommendations and findings from past inspections, appraisals audits, and other compliance evaluations performed by DOE-SR, DOE-HQ, the General Accounting Office (GAO), and regulatory agencies such as the Environmental Protection Agency (EPA) and South Carolina Department of Health and Environmental Control (SCDHEC). RAFTS is a. newly operational, sitewide system that contains evaluations of all SRS organizations. Findings or recommendations contained in the database are presently being verified to ensure that no findings are mistakenly closed. Two areas that are receiving expedited verification of previously closed findings are environmental and reactor safety issues. Once all environmental entries are verified, corrective actions on open findings can be implemented in an efficient manner. 
Savannah River Site

Interim Waste Management

Program Plan
II. General Site Information May 1992

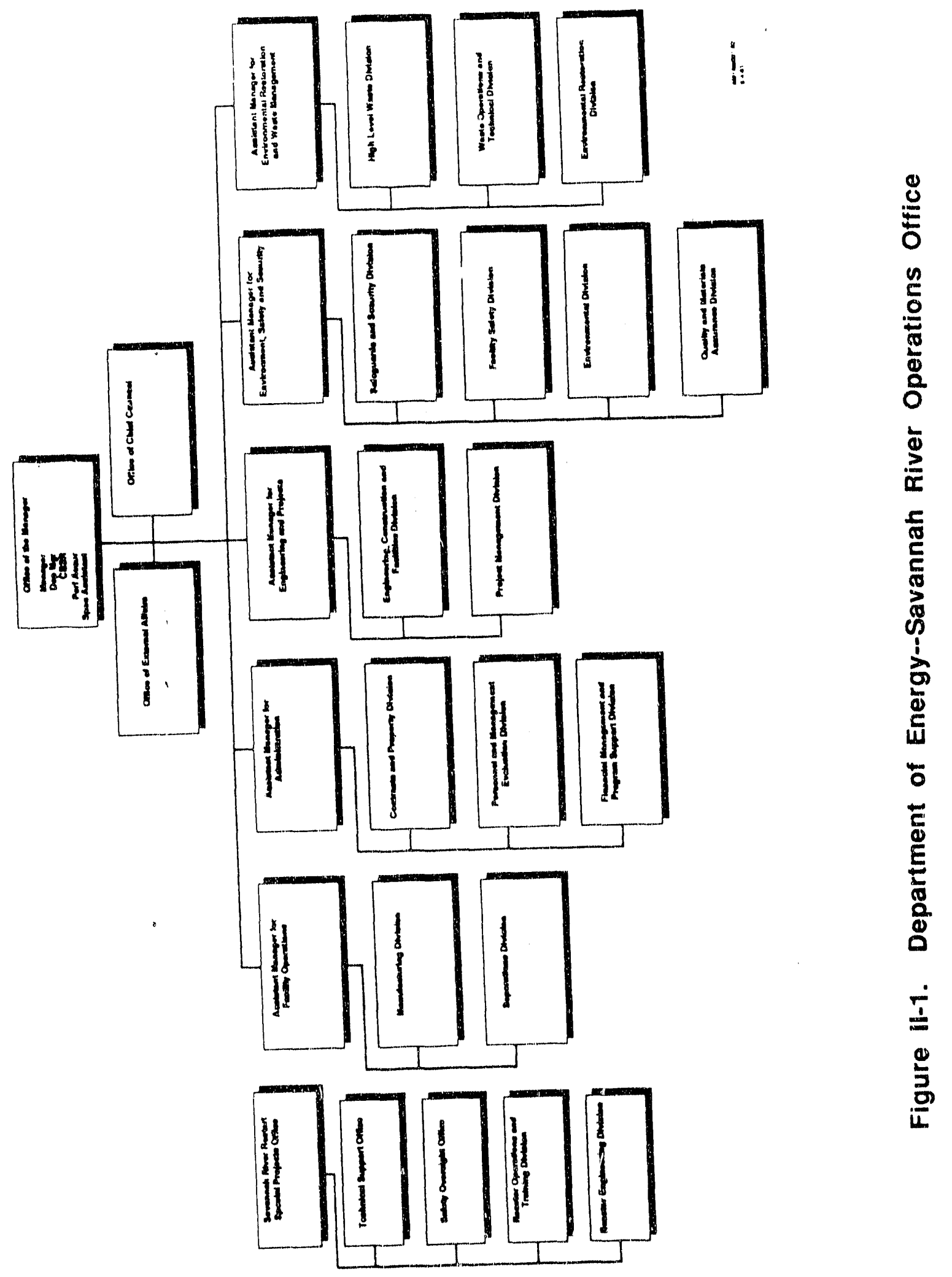




\section{Savannah River Site Interim Waste Management Program Plan}

\section{General Site Information}

May 1992

\subsection{SRS Contractor Organizations}

SRS contractors include: Westinghouse Savannah River Company (WSRC), the managing and engineering contractor; the Savannah River Ecology Laboratory (SREL), operated by the University of Georgia, which handles both basic and applied research designed to show how ecological entities (e.g., populations, terrestrial or aquatic systems, groundwater, etc.) function under both SRS-induced or relaxed stresses and natural conditions; Wackenhut Services Incorporated (WSI), which handles site security; U. S. Forest Service (USFS), which handles land management; and Bechtel Savannah River Company, which handles onsite construction activities (design and construction management). Each contractor is responsible for the safe, environmentally sound maintenance and management of its designated facilities, specific facility upgrades, operational support, waste management, and monitoring of operations and effluents for environmental compliance. Facility or building managers are responsible for managing their facilities in a safe, environmentally sound manner.

Most waste operations activities, environmental corrective and remedial actions, and decontamination and decommissioning (D\&D) of facilities, conducted at SRS are performed by or under contract to WSRC. WSRC has been assigned responsibility for management of the Interim Waste Program, implementation of the Environmental restoration Program, and management of the site. WSRC ensures that environmental design requirements are met and provides project support. WSRC also performs environmental research and development, provides an independent sitewide environmental surveillance program, remediates assigned facilities, and applies waste management technology to support operations and environmental restoration. WSRC is responsible for waste management and environmental compliance at its assigned facilities.

\section{Geographic Size}

SRS is located in south central South Carolina and occupies an almost circular area of approximately 325 square miles. The major geophysical feature is the Savannah River, which forms the southwestern boundary of the site and is also the South Carolina-Georgia border (Figure II-2). SRS occupies parts of three South Carolina counties--Aiken, Barnwell, and Allendale--and is closest to the major population centers of Augusta, Georgia and Aiken, South Carolina. The site is a controlled area with limited public access. The production facilities occupy less than eight percent of the SRS area. The remainder of the site is forested (approximately 80 percent) or is wetlands (Approximately 20 percent).

\section{Locations and Descriptions of Installations}

SRS comprises 18 production, service, and research and development areas scattered across the site. Figure II- 3 shows the locations of these areas. Each area is identified by a numerical and letter designation.

The primary facilities are the production facilities. The fuel and target components are mamufactured in the $3(0)-\mathrm{M}$ Area for shipments to the site reactors. The targets and fuel are placed in heavy-water-moderated production reactors for irradiation. Originally, the site operated five 


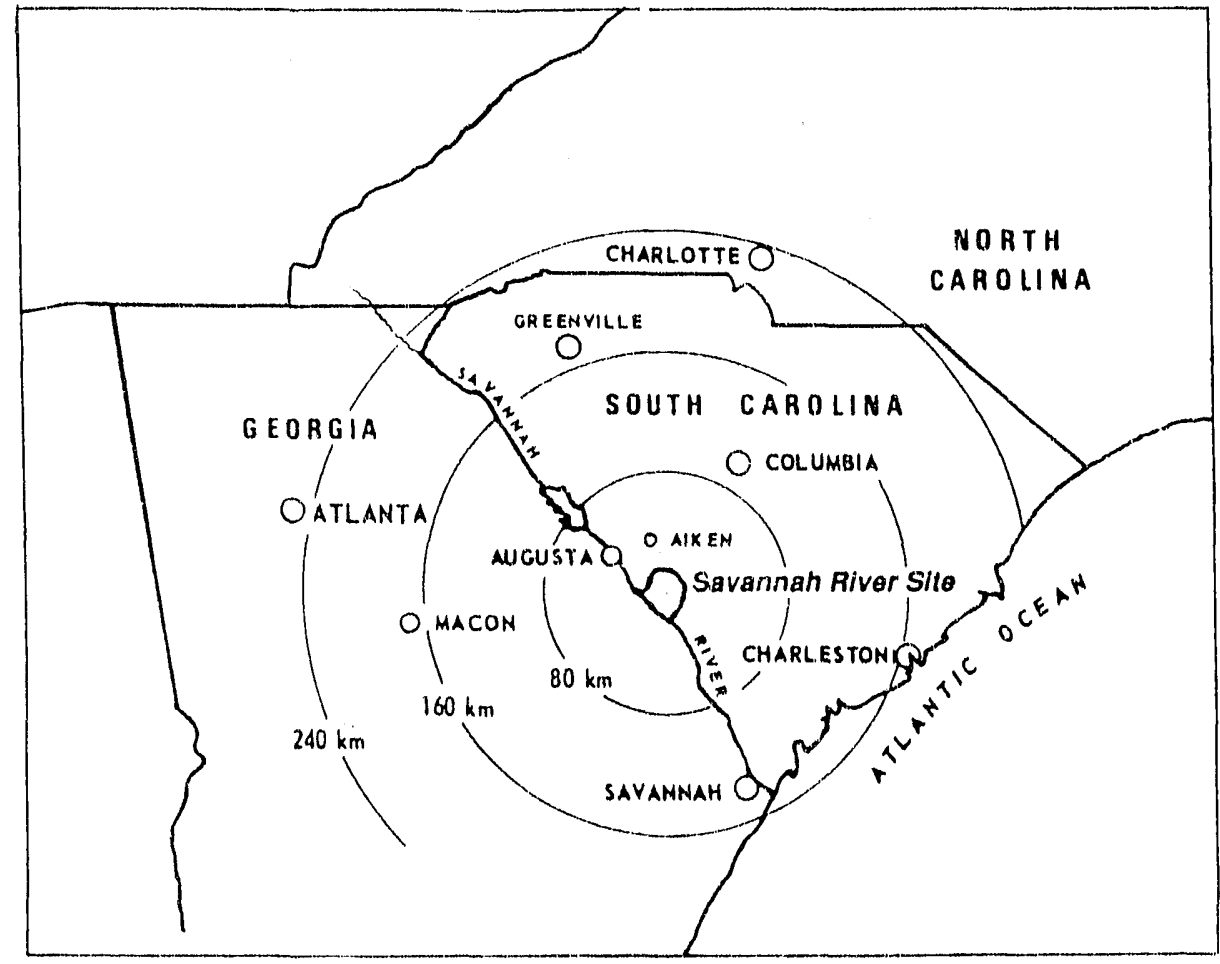

Figure II-2. Regional Location of SRS 


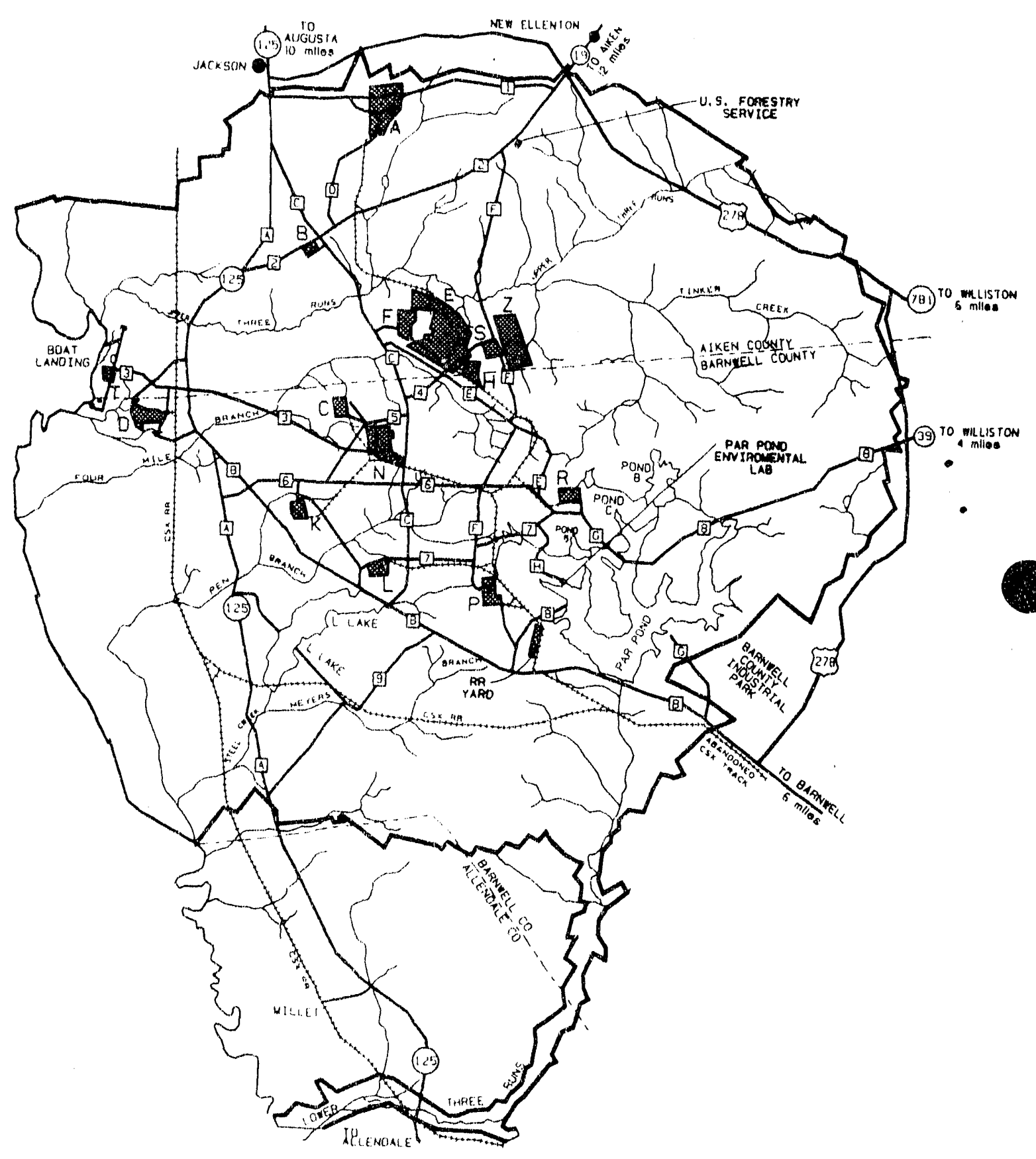

Figure II-3. Installation Sites at the Savannah River Site 


\section{Savannah River Site Interim Waste Management Program Plan}

\section{General Site Information \\ May 1992}

reactors. Currently, one of the reactors, located in the 100 -K Area, is being prepared for restart. The L Area Reactor is being prepared for warm standby. The P.Area Reactor is in cold standby. The reactors, located in $C$ and $R$ Areas, are in a shutdown status.

The SRS reactors operate at relatively low remperatures and pressures, and they do not produce electricity. The reactors are cooled by a heavy-water moderator, which is then circulated through heat exchangers in a closed loop. Inside the heat exchangers, water withdrawn from the Savannah River and onsite cooling reservoirs is used to remove heat from the heavy water without contacting it. The heavy water is then recirculated through the reactor vessel, and river water is released through an outfall to onsite streams or cooling ponds before returning to the river. The irradiated fuel is transported by shielded railroad cars to either the $200-\mathrm{F}$ or $-\mathrm{H}$ Area Canyons for the recovery of nuclear materials. The 200$)-\mathrm{F}$ and $-\mathrm{H}$ separations processes dissolve some of the irradiated components in acid and extract and separate the desired nuclear materials. Other products are extracted from irradiated components in separate processes in $\mathrm{H}$ Area. The liquid radioactive waste generated by the separation facilities is neutralized and stored in underground tanks until it can be processed into a glass waste form in the DWPF, currently under construction in the $2(0)-S$ and $-Z$ Areas. The glass waste form will be stored onsite until a federal geological repository is available. The nuclear material products are shipped to other DOE facilities for additional processing. The reactor, separations, and waste storage areas are at least four miles from the nearest site boundary. In addition to the underground radioactive waste storage tanks, SRS has a centrally lociated 196-acre site between F and H Areas for the disposal of solid low-level radioactive waste and the storage of transuranic (TRU) radioactive waste and mixed waste. The site also has storage buildings for nonradioactive hazardous wastes and mixed waste located in the Central Shops and U Areas along with a central sanitary landfill.

The site also contains many production support, research and development, and waste management facilities. There are three operational coal-fired powerhouses located in $A, D$, and $H$ Areas to generate electricity and steam. The largest powerhouse, which is located in the 400-D Area, produces electricity and exports process steam to $\mathrm{C}, \mathrm{F}, \mathrm{H}$, and $\mathrm{S}$ Areas through a sevenmile-long steamline. The heavy-water rework facility used to purify reactor moderator is also located in D Area. A semi-works facility used to study chemical and waste processing problems and to test production-scale equipment is located in the 600)-T Area. The 700-A Area includes the administrative facilities for DOFi and WSRC, SRL, and SREL.

WSRC is organized into fourteen divisions (Figure II-4). Following is a brief description of each division's responsibilities. Waste management activities are the responsibility of the Waste Management and Environmental Restoration Division.

\section{General Counsel Division}

The Gerieral Counsel Division provides legal advice to WSRC's management and interprets laws and contractual provisioni to licilitite SRS's compliance with legal requirements. 


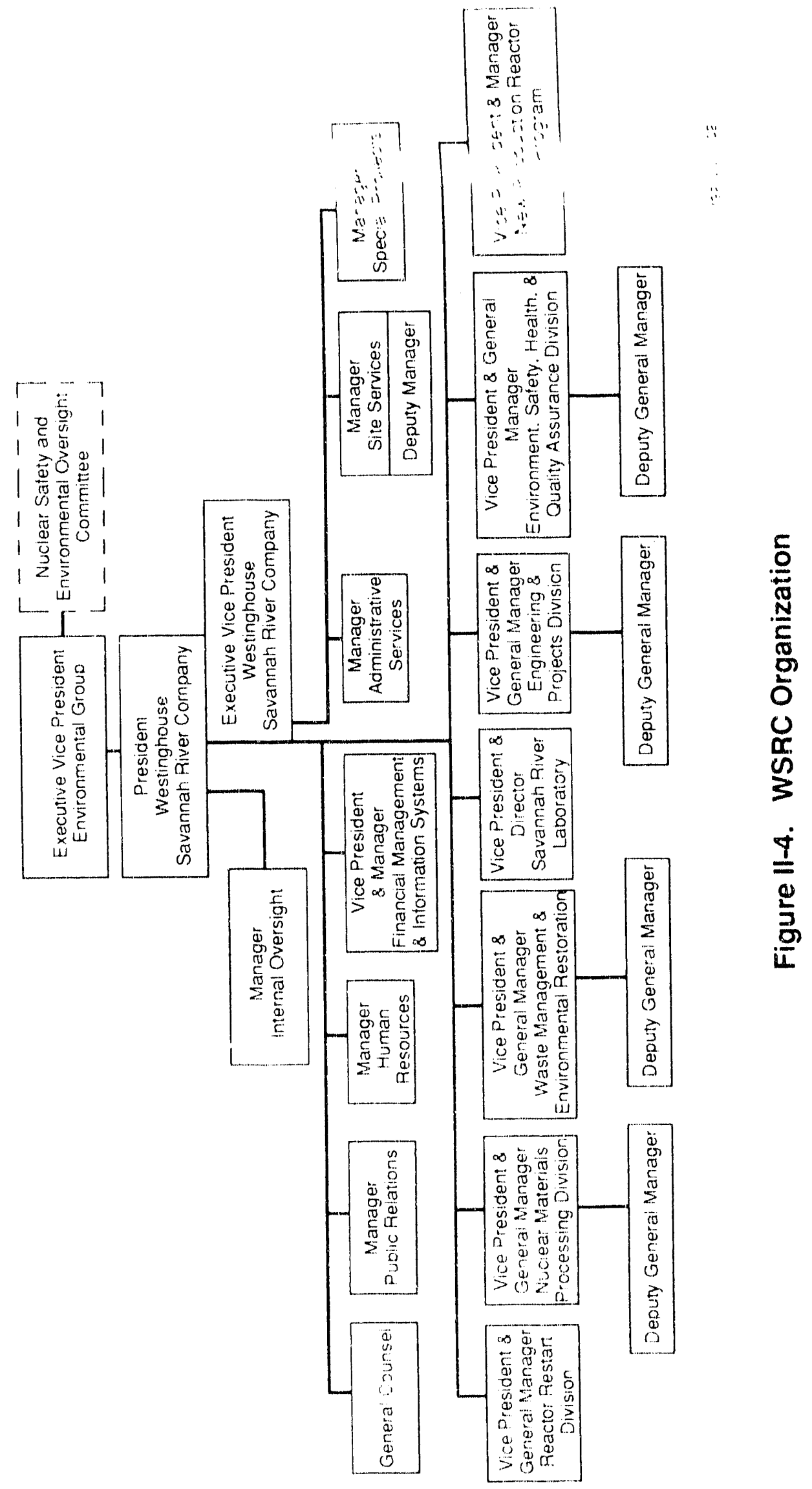




\section{Public Relations Division}

Public Relations coordinates community relations activities, including governmental communications and constituency building, community giving, and the visitors program; manages a speakers' bureau and develops communications materials to support all media and public information activities; develops and implements a community relations plan, required by Superfund legislation and public participation activities for Waste Management and Environmental Restoration; and coordinates proactive and reactive media and emergency response activities.

\section{Human Resources Division}

Human Resources is a staff support organization responsible for professional recruiting, general employment, compensation administration, the design and administration of employee benefits, employee assistance programs, equal employment opportunity, employee communication, the administration of employee relations policies and practices, and organizational and individual development and training.

\section{Financial Management anci Information Systems Division}

The Financial Management and Information Systems Division administrative operation supports the line organizations in achieving the site's mission. This organization includes Finance and Information Resource Management Departments. These departments provide a variety of services associated with accounting, budgeting, financial management, administration of employee benefits, invoice management and processing, capital investment management, computer, and telecommunication support.

\section{Administrative Services Division}

The Administrative Services Division consists of Training Integration; Planning, Support, and Analysis; Management Services; Procurement and Materials Management; and Strategic Programs.

\section{Site Services Division}

The Site Services Division consists of the Transportation, Quality Assurance, Central Services Works Engineering, Site Utilities, Training, Operations Integration, Facilities and Services, Fire Protection, and Digital Control and Systems Departments.

\section{Special Projects Division}

The special Projects Division is responsible for coordinating site production and cost effectiveness efforts. 


\section{Savannah River Site Interim Waste Management Program Plan}

\section{General Site Information}

May 1992

\section{Peactor Restart Division}

The Reactor Restart Division under the direction of its manager, is responsible for the safe restarting of $\mathrm{K}$ Reactor and maintenance of $\mathrm{L}$ Reactor on warm standby and P Reactor on cold standby.

\section{Nuclear Materials Processing Division (NMPD)}

NMPD is responsible for Reactor Materials, Separations, Nuclear Materials Processing, Tritium, Program Control and Integration, and Total Quality and Performance Improvement.

Reactor Materials, Separations, and Tritium are responsible for waste control and management.

Reactor Materials (RM). RM is responsible for providing fuel and targets to support SRS reactor operations. These activities must comply with Federal and State environmental regulations, DOE orders and Tiger Team findings, and SRS waste management goals. (The Tiger Team is an independent oversight group formed by the Secretary of Energy, Admiral James D. Watkins, to conduct assessments of the Environment, Safety, and Health programs at DOE facilities.)

The major activities associated with waste control and management needed to accomplish the RM mission are divided into the general categories of air effluents, solid wastes and wastewater effluents. The primary air effluent activities are the replacement of operations using chlorofluorocarbons (CFC) especially degreaser operations and the installation of improved radioactive air emissions monitoring systems. The primary solid waste activities are the operation of the 313-M waste comfactor; the excess chemical and material disposal program; the waste Filtration and Stabilization Facility (FIST) project; and the operation of two hazardous waste storage facilities: the Process Waste Interim Treatment/Storage Facility (IT/SF) and the Mixed Waste Storage Shed (MWSS). The primary waste water activities are the Liquid Effluent Treatment Facility (LE'TF) operations, the wastewater effluent toxicity reduction study, the M-Area process sewer repair and replacement program, and the M-Area storm sewer upgrade program.

Tritium. Tritium's responsibilities include identification, handling, packaging, short-term storage, and shipment of job-control (low-level radioactive), mixed, and hazardous waste. Waste volume reduction of low-level job control waste by compaction is an important part of Tritium's waste management program.

Waste minimization is also part of Tritium's waste management activities. Material substitution, procedural control of material entering radiological controlled areas, and revised work practices to eliminate the use of hazardous materials are all elements of Tritium's waste minimization effort.

Separations. Separations' responsibilities consist of activities ranging from treatment, handling, and storage to disposil operations. Waste management treatment activities in operating facilities include packaging and handling of low-level, intermediate-level, and TRU waste. 


\section{Savannah River Site Interim Waste Management Program Plan}

II. General Site Information
May 1992

\section{Waste Management and Environmental Restoration (WM\&ER) Division}

WM\&ER is divided into six departments, three of which deal with waste management: Defense Waste Processing Facility Operations, Interim Waste Program, and Environmental Restoration.

Defense Waste Processing Facility. DWPF immobilizes liquid high-level radioactive waste currently stored at SRS into borosilicate glass. This operation includes chemically treating two unique waste streams, mixing them with a ground borosilicate glass and then heating the mixture in an electric melter to 1130 degrees centigrade. The molten mixture is then poured into ten-feet-tall, two feet in diameter stainless-steel canisters and allowed to harden. The outer surface of the canisters is then decontaminated to the Department of Transportation (DOT) standards, welded closed, and temporarily stored onsite for eventual transport to and disposal in a permanent federal geological repository.

Interim Waste Programs. IW Programs manages all types of waste. Radioactive waste is categorized according to how it must be dealt with and managed according to standards established by the EPA and specified DOE orders. HLW requires considerable shielding, is long-lived and will be disposed of in a geologic repository. Low-level waste (LLW) is defined as that radioactive waste that is not HLW. LLW is normally solid waste that is containerized according to its radioactivity and disposed of onsite. TRU waste generated onsite generally requires little shielding, is extremely long-lived, and will also be disposed of in a federal geologic repository. Hazardous waste is defined by several environmental laws and managed according to requirements established by the EPA and states. Mixed waste is waste that contains both radioactive and hazardous components. It is managed to meet requirements for its radioactive and hazardous components imposed by the EPA, states, and DOE. Sanitary waste, which is neither radioactive nor hazardous, is managed according to established federal and state regulations (DOE 1989a).

The strategy for achieving SRS Waste Management objectives is to:

- Ensure that there is a method to dispose of the waste before the waste is generated.

- Reduce/minimize waste generation.

- Recycle/reuse consumed wastes in processes as much as practical.

- Segregate waste at point of generation such that uncontaminated waste or hazardous waste does not become radioactively contaminated.

- Segregate wastes at the generating location for temporary storage in permitted facilities as required.

- Incinerate to destroy hazardous wastes and reduce waste volume.

- Treat wastes to minimize mobility before final disposal.

- Dispose of newly generated wastes ultimately in monitored repositories.

- Maintain integrity of existing disposal sites to ensure performance objectives are met. 
Environmental Restoration (ER). ER is responsible for all aspects of assessment and cleanup of sites and facilities that are no longer a part of active operations but are contaminated with various quantities of hazardous, radioactive, or mixed waste materials. ER is also responsible for inactive waste sites which are nonhazardous and nonradioactive. ER performs two sets of activities: Remedial Actions and Decontamination and Decommissioning (D\&D). The Remedial Action tasks encompass 1) site characterization, analysis of cleanup alternatives, and selection of remedy; 2) cleanup and site closure; and 3) site compliance monitoring. D\&D is concerned with the safe caretaking of inactive nuclear facilities and either their decontanination or their complete dismantling and removal.

\section{Savannah River Laboratory (SRL)}

SRL's research and development activities centers on support for site waste management production operations, solution of production technical problems, and enhancement of existing production processes. The emphasis is on development and demonstration of technology for waste management operations. The majority of these efforts are driven by numerous and diverse new production waste management initiatives. This is accomplished through the use of engineering-scale facilities and laboratories.

SRL consists of seven units: Nuclear Reactor Technology and Scientific Computations, Chemical Processes and Environmental Technology, Defense Waste Processing and Hydrogen Technology, Laboratory Operations and Engineering, Consulting Scientists, Savannah River Research Center, and Safety Analysis and Risk Management. Waste Management activities are included under Chemical Processes and Environmental Technology, Defense Waste Processing and Hydrogen Technology, and Safety Analysis and Risk Management.

Specific SRL responsibilities include:

- Developing new products and processes consistent with DOE objectives and policies.

- Improving existing processes and products.

- Providing basic technical information for the design of equipment and operation of processes.

- Providing and keeping up to date:

- Technical Manuals that give the technical bases for plant processes.

- Technical Standards that give the limits within which plant processes must be operated.

- Safety Analysis Reports that provide an evaluation of hazards associated with each operation and bases for the Tiechnical Standards.

Systems Analyses that provide comprehensive assessments of system functions and processes. 


\section{Program Plan}

- Reviewing and approving Test Authorizations for nonroutine operations and operation outside the limits imposed by Technical Standards.

- Maintaining liaison on technical matters with DOE, other DOE contractors, and other laboratories.

- Operating the experimental facilities.

- Performing dose modeling and dose assessments.

- Providing technical assistance to Waste Management Operations when requested.

- Coordinating and carrying out advanced operational planning studies and maintaining liaison with other DOE planning groups.

- Coordinating environmental studies as related to SRS and maintaining liaison on environmental matters with DOE, other DOE contractors, other government agencies, and other environmental study groups.

\section{Engineering and Projects Division (E\&PD)}

E\&PD provides construction liaison for projects for which it is responsible. For smaller projects, design is also provided by E\&PD. The division assists as necessary in all site tasks requiring new or modified facilities.

E\&PD will provide site activity support by implementing such programs as:

- Full support to operations in restarting the reactors.

- Computer automation of the design and construction process, the project management system, and the work management system.

- A division quality improvement plan.

- Execution of a project management system that meets the requirements of DOE Order $47(00.1$ to include configuration management, design reviews, and document controls.

- Meeting established project completion schedules.

- Implementation of NQA-1, "Quality Assurance Requirement for Nuclear Facilities."

- Maintenance and restoration of aging facilities.

- Development of training and procedures. 


\section{Envirenment. Safety. Heglth, and Quality Assurance (ESH\&QA) Division}

The ESH\&QA Division provides support in areas that are essential for the safe, secure, and responsible operation of the site. ESH\&QA is divided into the following organizations: Health Protection, Environmental Protection, Safety, Quality Assurance, Analytical Laboratories, Safeguards and Security, Medical, and allocated ESH\&QA (administrative services).

The Environmental Protection Department's Environmental Restoration/Groundwater Protection Section (ER/GW) within the ESH\&QA Division is responsible for the coordination of all regulatory guidance on all environmental restoration and groundwater protection programs, all consent agreements, implementation of the Federal Facility Agreement, and integration of all RCRA/CERCLA activities.

The ESH\&QA overall plan is described in its mission statement: "To provide guidance, independent critical assessment and necessary support to WSRC divisions in order to achieve the highest standards of safety, quality, environmental and health protection, safeguards, security, emergency preparedness and medical services."

\section{New Production Reactor (NPR) Program}

The NPR Division is responsible for the following major activities:

- Completing HWR technology transfer for conceptual design.

- Performing engineering activities to provide a basis for technical validation of conceptual design.

- Supporting HWR-NPR safety review process and the establishment of safety requirements.

- Managing and providing support for the SRS portion of the programmatic NPR/ Environmental Impact Statement to meet NEPA requirements.

- Defining, managing, and performing, where appropriate, all development programs required to support the Heavy Water Reactor-New Production Reactor (HWR-NPR).

- Developing and validating required HWR-NPR management systems to ensure a continuity of project management beginning with Title I design through HWR-NPR operation.

- Providing direct support to the Office of New Production Reactor (ONPR) in the development of NPR program criteria, requirements, and procedures.

- Providing necessary project general management support.

- Initiating development of a QA program that satisfies the requirements of NQA-1 and DOE Order 57()()-6B.

- Initiating design for the Heavy Water Processing Facility. 
- Establishing the Configuration Management Plan for the program and developing the system architecture and interface requirements.

\subsection{Lead Responsibility For Waste Management Activities}

Five departments and one section within the SR Interim Waste Program (Figure II-5) are responsible for onsite waste management activities. These are:

\section{Waste Management Technology (WMT)}

WMT maintains continual surveillance of processes through technically trained personnel assigned to production areas. The department focuses on tank farm assistance, solid waste, hazardous waste and environmental programs, and inspection and video monitoring. WMT approves production operating procedures and work orders to change process facilities and issues Test Authorizations for management approval of significant deviations from normal operations.

\section{Waste Management Operations}

Waste Management Operations (WMO) is the custodian of all Waste Management facilities. These include the tank farms, the Solid Waste Complex now jointly called "E-Area," the maintenance facility, the Effluent Treatment Facility, the hazardous and mixed waste storage building, and the sanitary landfill. WMO has the responsibility of ensuring that maintenance and construction work is done safely and according to specifications. WMO approves maintenance and construction projects or work orders and job plans and is a member of each committee for acceptance of new or modified facilities.

\section{Waste Management Works Engineering}

Waste Management Works Engineering (WMWE) is responsible for providing the maintenance, electrical, and instrumentation support for Waste Management Facilities' Managers. WMWE's mission is to meet the needs of our customers by "Total Quality" engineering and operations support, maintenance and upgrading of existing facilities, safe and environmentally sound startup of new facilities, and operation of heavy equipment in the Waste Management area. WMWE's vision is to be recognized as the model of excellence in all their works. Their work will be accomplished in a way that provides individual involvement and team effort to ensure improvement of safety, environmental protection, quality, customer satisfaction and the capability to meet expanding needs. 


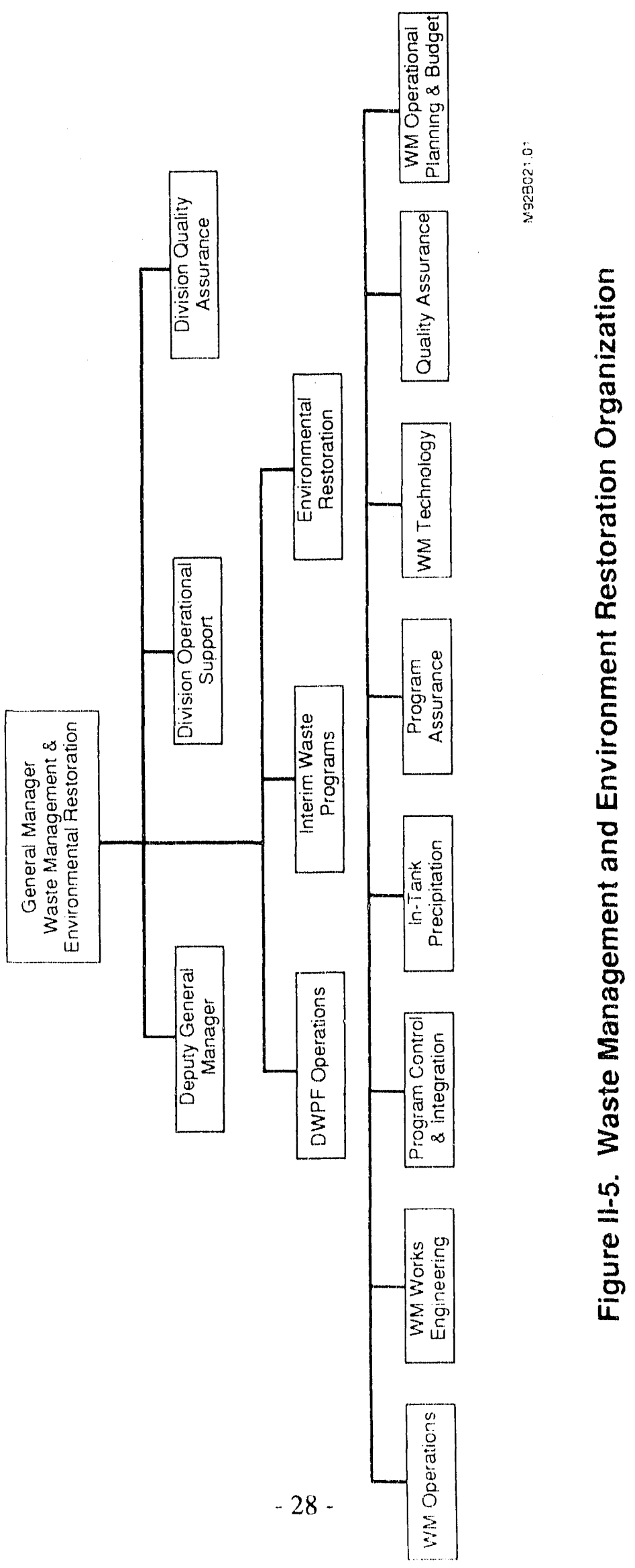




\section{Savannah River Site Interim Waste Management Program Plan}

II. General Site Information
May 1992

\section{Waste Management Program Control and Integration}

Waste Management Program Control and Integration (WMPC\&l) is responsible for the design liaison associated with the Interim Waste Management projects. WMPC\&I also provides budget, scheduling, environmental, and staff services to the WM-Program Management Team (PMT). The department provides input to all pertinent site planning documents/efforts for the PMT. Several key documents are the site integrated schedules for operations and projects, the site operational program plan, the site specific plan, and the annual budget submission.

\section{Waste Management Programs--Quality}

Waste Management Quality Assurance (WMOSA) assists the other five Waste Management departments in implementing a quality assurance program and serves an oversight function in quality assurance matters. WMQA personnel serve as consultants, perform independent inspections and surveillances of Waste Management activities, and review and approve Quality Assurance (QA) procedures, test procedures, procurement documents, and design input documents.

\section{Waste Minimization}

Waste Minimization is responsible for coordinating and leading the site in the Waste Minimization Program. The program is a comprehensive, organized effort to systematically reduce waste generation while meeting regulations and satisfying customer expectations. It is designed to eliminate or minimize pollutant releases to all environmental media from all aspects of the site's operation. See Appendix IV for the 1991 Waste Reduction Report on waste reduction activities, program performance, and waste reduction goals and objectives.

\section{B. IDENTIFICATION OF WASTE MANAGEMENT FACILITIES}

\subsection{Identification and Location of Facilities}

Figure 11-6 shows the location of Waste Management facilities. These facilities are provided to: 1) receive radioactive wastes generated by the routine and nonroutine operations of the various production and research facilities at the Savannah River Site, especially the fuel and target chemical processing facilities; and 2) store and process these wastes as required to: (a) prevent the escape to the environment (off or onplant) of any potentially harmful quantity of radionuclides, (b) avoid the exposure of plant workers and the public to potentially harmful levels of radiation emanating from these wastes, (c) keep the stored wastes in retrievable form to facilitate their eventual removal for conversion to more stable forms and placement in permanent disposal facilities, (d) prepare highlevel waste for feed to DWPF, and (e) minimize waste volumes.

Currently, SRS has 51 large subsurface-waste tanks for storing aqueous high-level radioactive wilstes. These tanks are localed in the Separations areas near the center of the plant. Twenty-two lanks are in F Area, and 29 are in H Area (Figures II-7 and II-8). Solid radionctive waste is stored 


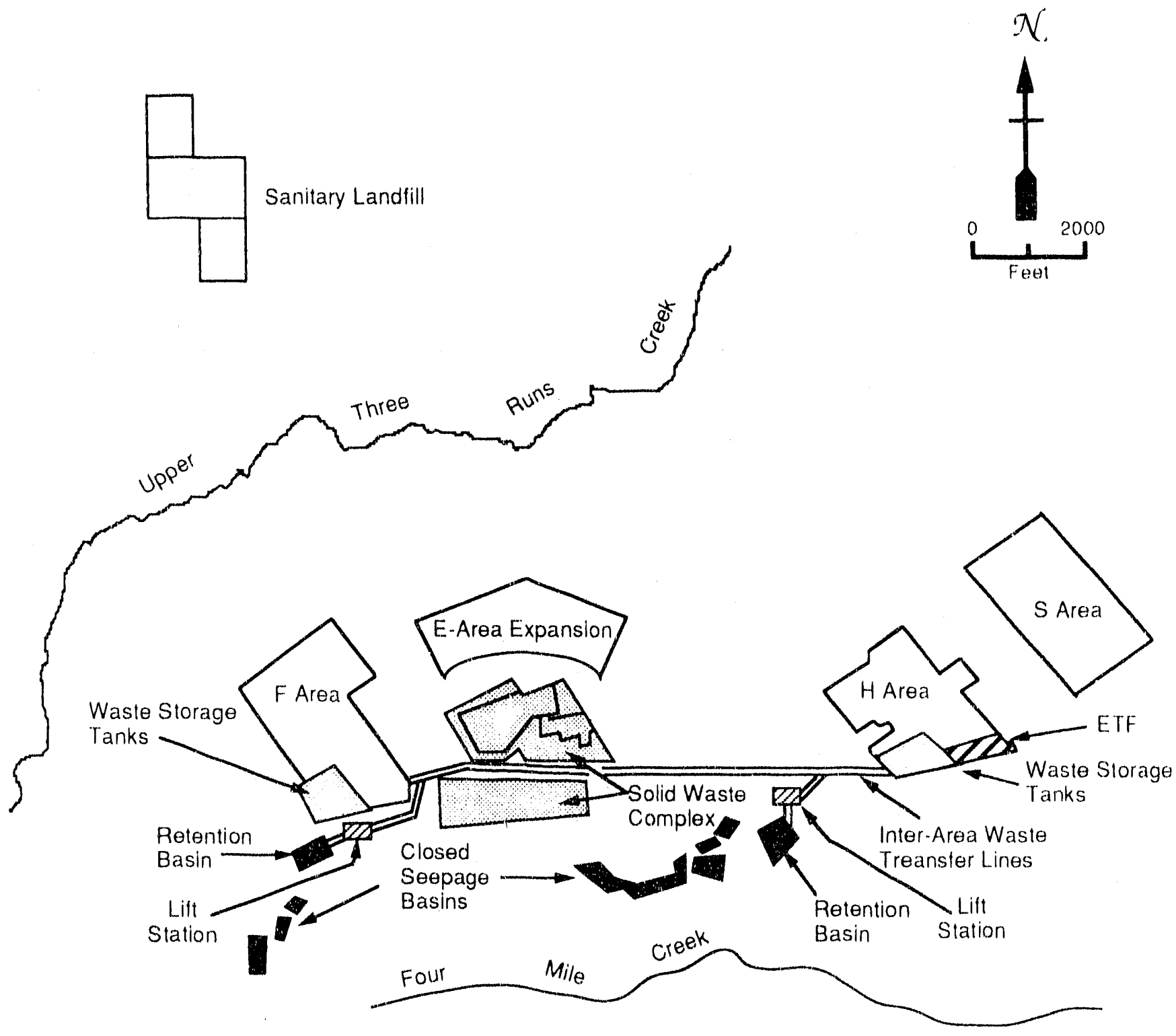

M9?B021.10

Figure II-6. Waste Management Facilities 


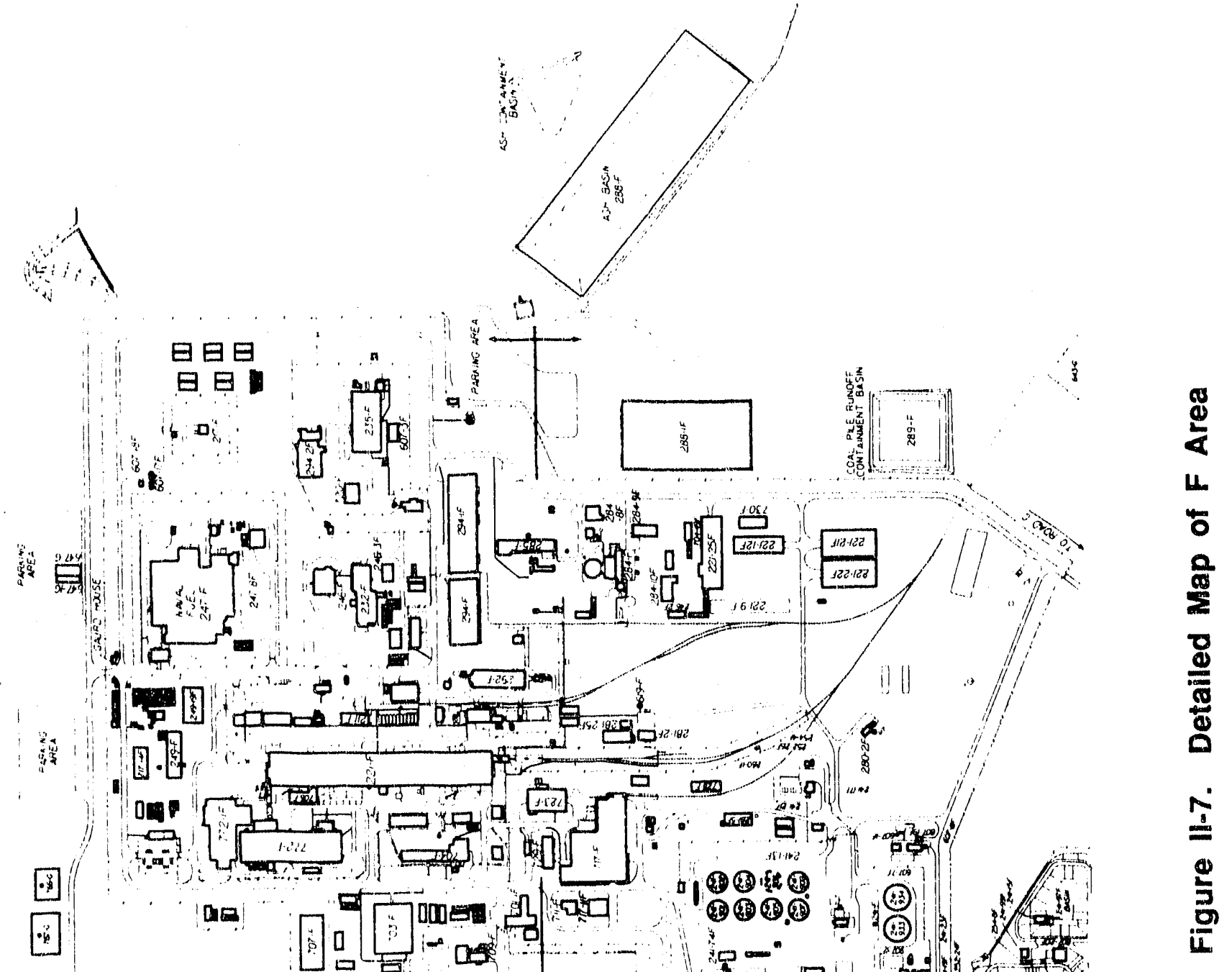


Savannah River Site Interim Waste Management

Program Plan
II. General Site Information

May 1992

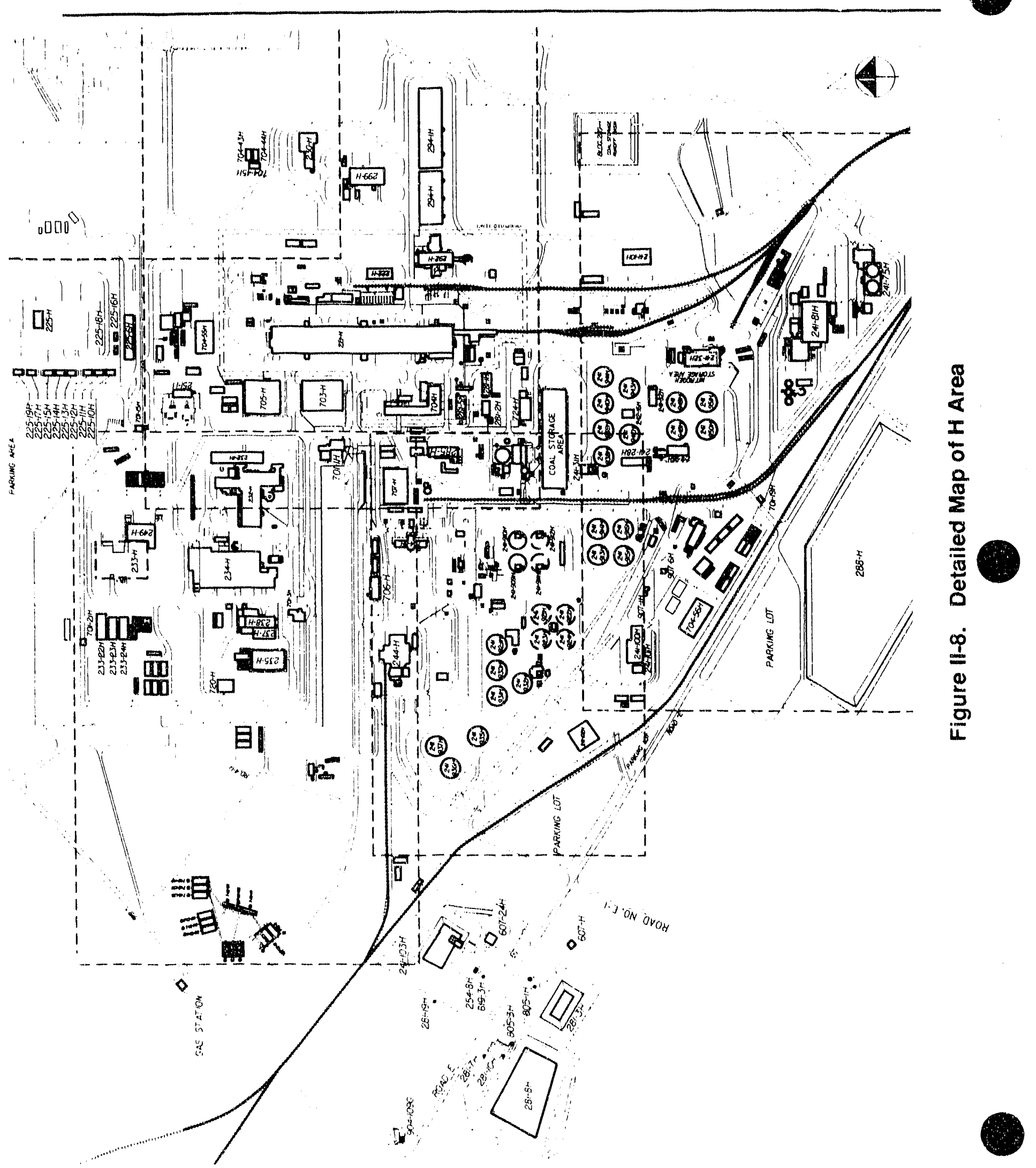


in or disposed of in the Solid Waste Complex (E Area), located between the two Separations areas. Other facilities under Waste Management custodianship are the:

- Retention basins near $\mathrm{F}$ and $\mathrm{H}$ Areas for holding liquid effluents with potentially higher radioactivity.

- ETF for treatment of low-level liquid streams.

- Maintenance Facility (299-H) for repairing contaminated equipment.

- Experimental Transuranic Waste Assaly lacility (ETWAF) and the Waste Certification Facility (WCF).

- Hazardous and mixed waste storage buildings.

- Solvent storage tanks.

- Sanitary and industrial landfills.

- Compactor for low-level solid waste.

- Landfill monitoring building for confirming that suspected clean waste is acceptable for disposal in the Sanitary Landfill.

- ITP and Extended Sludge Processing (ESP) for preparation of feed for DWPF.

- New Waste Transfer Facilities: HDB-8 and Low-Point Drain Tank to support tank farm to DWPF/ ETF transfers (Figure II-9). 


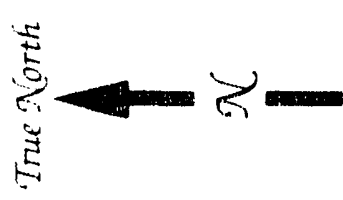

N
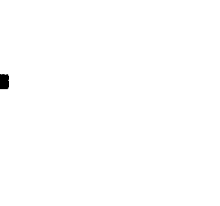

$\theta$

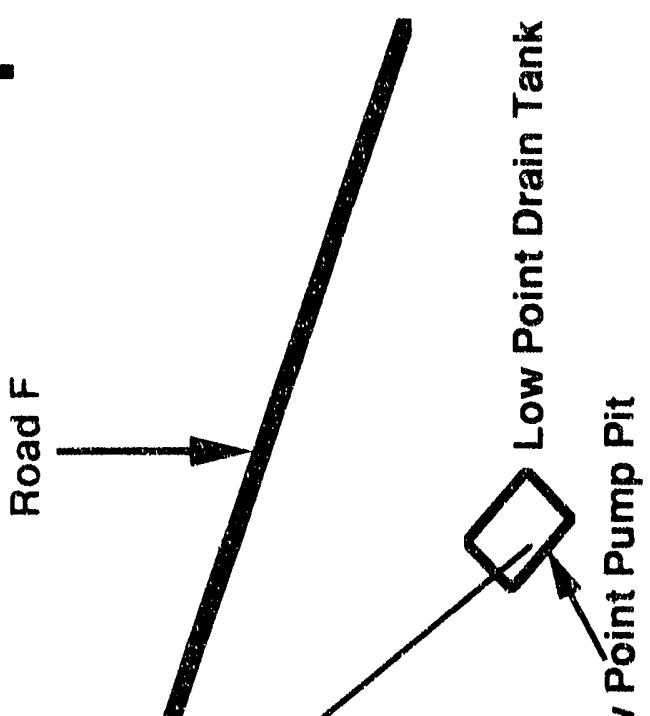

ס

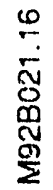

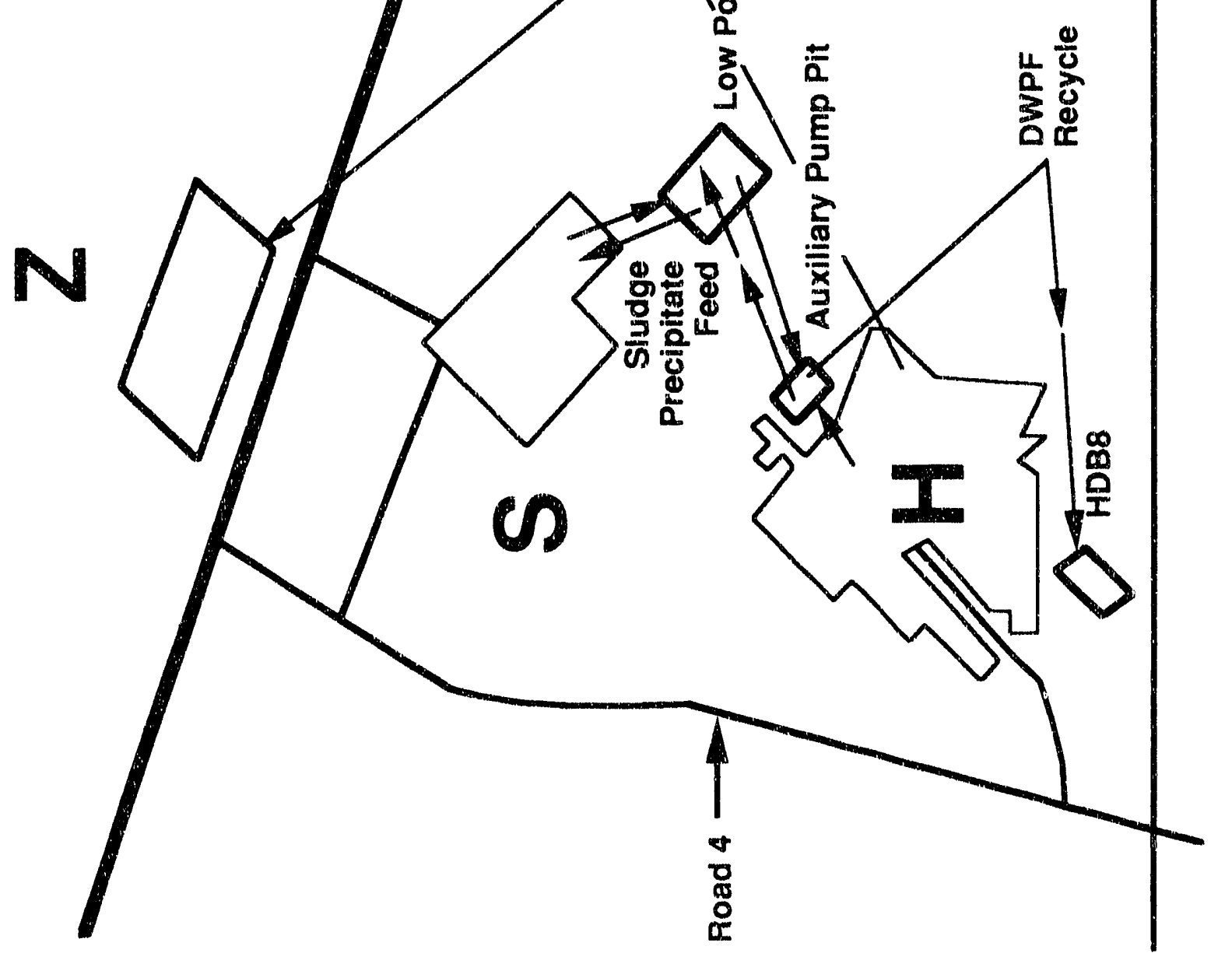

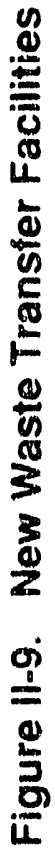


III. RADIOACTIVE AND MIXED WASTE MANAGEMENT 
BLANK 


\section{RADIOACTIVE AND MIXED WASTE MANAGEMENT}

This section describes radioactive and mixed waste management operations at this site, and includes descriptions of all systems and facilities used to store, treat, and eventually dispose of all such waste.

Radioactive waste is all solid, liquid, or gaseous material that contains radionuclides regulated under the Atomic Energy Act of 1954, as amended, and of negligible economic value considering costs of recovery. Radioactive waste is categorized as high-level waste (HLW), low-level liquid waste (LLW), and transuranic (TRU) waste.

Examples of hazardous waste, as defined by South Carolina Hazardous Waste Management Regulations, are lead, cadmium, and mercury. Hazardous waste that is also radioactively contaminated is designated mixed waste and is segregated for storage in South Carolina Department of Health and Environmental Control-permitted facilities until a treatment or disposal facility can be constructed. The Hazardous Waste/Mixed Disposal facility is designed to eliminate the storage of newly generated and untreated hazardous and mixed wastes. Construction on the Consolidated Incineration Facility is scheduled to begin in 1992; the incinerator will be used to detoxify and reduce the volume of radioactive, hazardous, and mixed waste. Buildings $643-29 \mathrm{G}$ and $709-2 \mathrm{G}$ are presently storing intermediate and low-activity mixed waste, respectively. HLW is also considered a mixed waste, as is some TRU waste.

\section{A. HIGH-LEVEL WASTE}

\subsection{Overview}

HLW is defined as the highly radioactive waste material that results from the reprocessing of spent nuclear fuel. It includes liquid waste produced directly in reprocessing and any solid waste derived from the liquid. HLW contains a combination of transuranic waste and fission products in concentrations requiring permanent isolation.

SR liquid waste, as received in the waste tanks, is made up of many waste streams generated during the recovery and purification of transuranic products and unburned fissile material from spent reactor fuel elements. These wastes are neutralized to excess alkalinity (pH 10) to 13) before being transferred to the million-gallon underground storage tanks.

In the storage tanks, the insoluble components of the waste (about $5-10 \%$ ) settle to form a layer of sludge on the tank bottom. Fresh waste contains many short-lived radionuclides. The radioactivity of fresh waste is reduced by about 65 to $80 \%$ in one to two years of storage from the decay of short-lived radionuclides. Table III-1 shows the current radionuclide inventory of HLW at SRS. The chemical composition of SRS HLW is shown in Table III-2. Flowcharts are shown in Figures III-1 and III-2. 
Table III-I. Current Radionuclide Inventory in High-Level Waste at SRS*

\begin{tabular}{|c|c|c|}
\hline & Radionuclide & $\begin{array}{l}\text { Radioactivity, } \mathrm{Ci} \\
\text { Total }\end{array}$ \\
\hline & ${ }^{90} \mathrm{Sr}$ & $1.29 E+08$ \\
\hline & $90 \mathrm{Y}$ & $1.29 \mathrm{E}+08$ \\
\hline & $99 \mathrm{Tc}$ & $2.37 \mathrm{E}+(05$ \\
\hline & $106 \mathrm{Ru}$ & $8.19 E+(13$ \\
\hline & $106 \mathrm{Rh}$ & $8.19 \mathrm{E}+05$ \\
\hline & $125 \mathrm{Sb}$ & $3.87 \mathrm{E}+05$ \\
\hline & $137 \mathrm{Cs}$ & $1.33 E+08$ \\
\hline & $137 \mathrm{~m} \mathrm{Ba}$ & $1.24 E+08$ \\
\hline & ${ }^{144} \mathrm{Ce}$ & $5.33 E+06$ \\
\hline & $144 \mathrm{Pr}$ & $5.33 E+06$ \\
\hline & $147 \mathrm{Pm}$ & $3.04 E+07$ \\
\hline & $233 \mathrm{U}$ & $2.48 \mathrm{E}-() 1$ \\
\hline & $235 \mathrm{U}$ & $2.62 \mathrm{E}-01$ \\
\hline & $238 \mathrm{U}$ & $2.19 \mathrm{E}+01$ \\
\hline & $238 \mathrm{Pu}$ & $1.60 \mathrm{E}+(06$ \\
\hline & $239 \mathrm{Pu}$ & $2.20 \mathrm{E}+(04$ \\
\hline & $240 \mathrm{Pu}$ & $1.04 E+04$ \\
\hline & $241 \mathrm{Pu}$ & $1.42 E+06$ \\
\hline & $242 \mathrm{pu}$ & $1.70 \mathrm{E}+(01$ \\
\hline & $244 \mathrm{Cm}$ & $1.47 E+(04$ \\
\hline Total & & $5.62 E+(08$ \\
\hline Specif & ty, $\mathrm{Ci} / \mathrm{L}$ & 4.26 \\
\hline
\end{tabular}

* Information is from Integrated Data Base for 1991: U.S. Spent Fuel and Radioactive Waste Inventories, Projections, and Characteristics. DOE/RW-(O)O6, Rev. 7, Prepared by Oak Ridge National Laboratory (October 1991). 
Table III-2. Typical Chemical Composition of SRS High-Level Liquid Waste

\begin{tabular}{|c|c|c|}
\hline Component & Sludge ${ }^{a}$ wt $\%$ & Supernate, ${ }^{b}$ wt $\%$ \\
\hline $\mathrm{NaNO}_{3}$ & 2.83 & 48.8 \\
\hline $\mathrm{NaNO}_{2}$ & - & 12.2 \\
\hline $\mathrm{NaOH}$ & 3.28 & 13.3 \\
\hline $\mathrm{Na}_{2} \mathrm{CO}_{3}$ & - & 5.21 \\
\hline $\mathrm{NaAL}(\mathrm{OH}) 4$ & - & 11.1 \\
\hline $\mathrm{Na}_{2} \mathrm{SO}_{4}$ & - & 5.99 \\
\hline $\mathrm{NaF}$ & - & 0.18 \\
\hline $\mathrm{NaCL}$ & - & 0.37 \\
\hline $\mathrm{Na}_{2} \mathrm{SiO}_{3}$ & - & 0.14 \\
\hline $\mathrm{Na}_{2} \mathrm{CrO}_{4}$ & - & 0.16 \\
\hline $\mathrm{Ni}(\mathrm{OH})_{2}$ & 1.94 & - \\
\hline $\mathrm{HgO}$ & 1.6 & - \\
\hline $\mathrm{UO}_{2}(\mathrm{OH})_{2}$ & 3.4 & - \\
\hline Iron Oxide & 30.1 & - \\
\hline Aluminum Oxide & 32.9 & - \\
\hline Manganese Oxide & 0.51 & - \\
\hline Calcium Carbonate & $4 .()$ & - \\
\hline Silicon Oxide & 5.9 & - \\
\hline Zeolite & 3.7 & - \\
\hline
\end{tabular}

a Analysis of insoluble solids (dry basis).

b Analysis of soluble solids (dry basis). 
Savannah River Site

Interim Waste Management

Program Plan
III. Radioactive and

Mixed Waste Managomont

May 1992

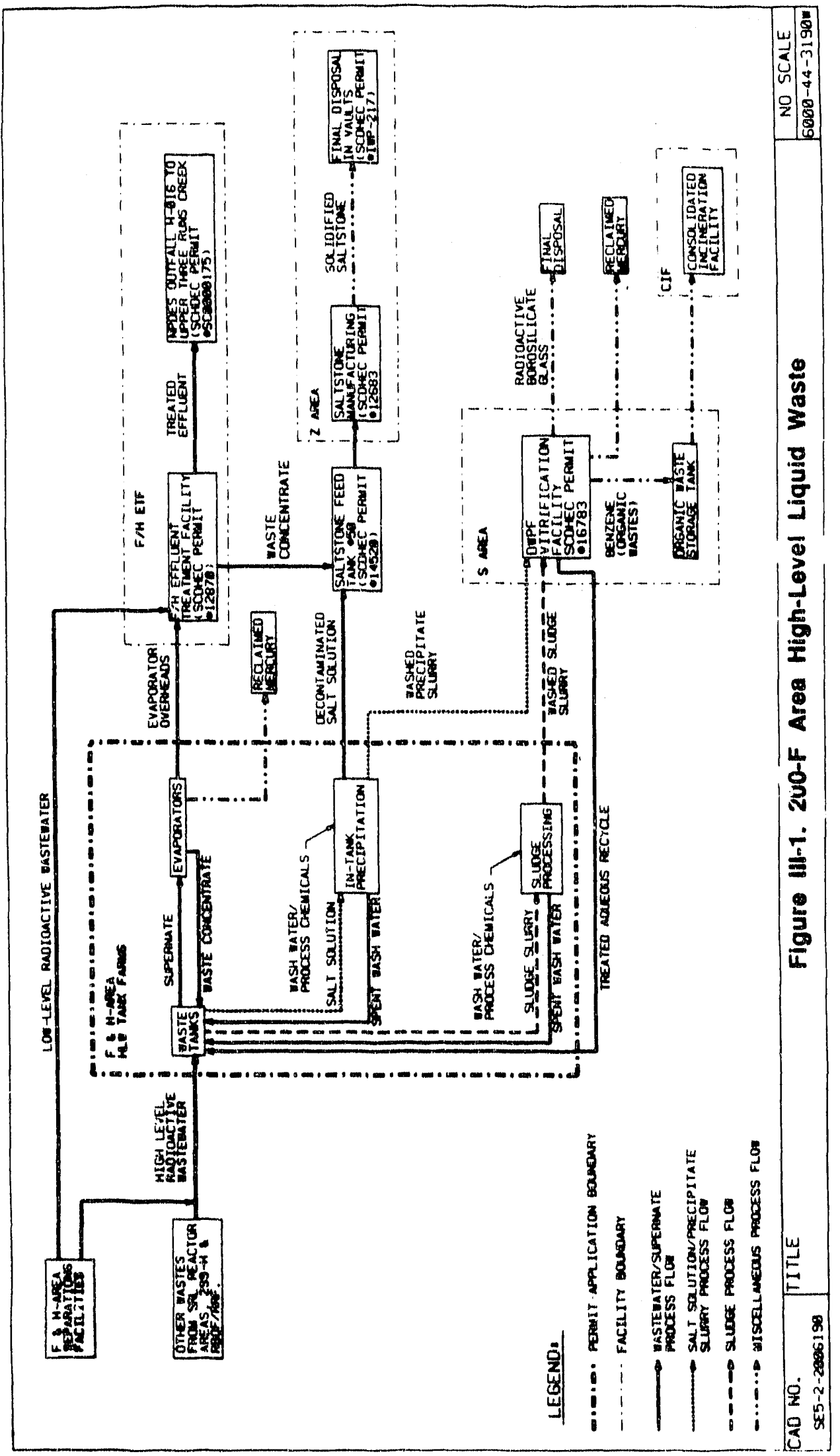




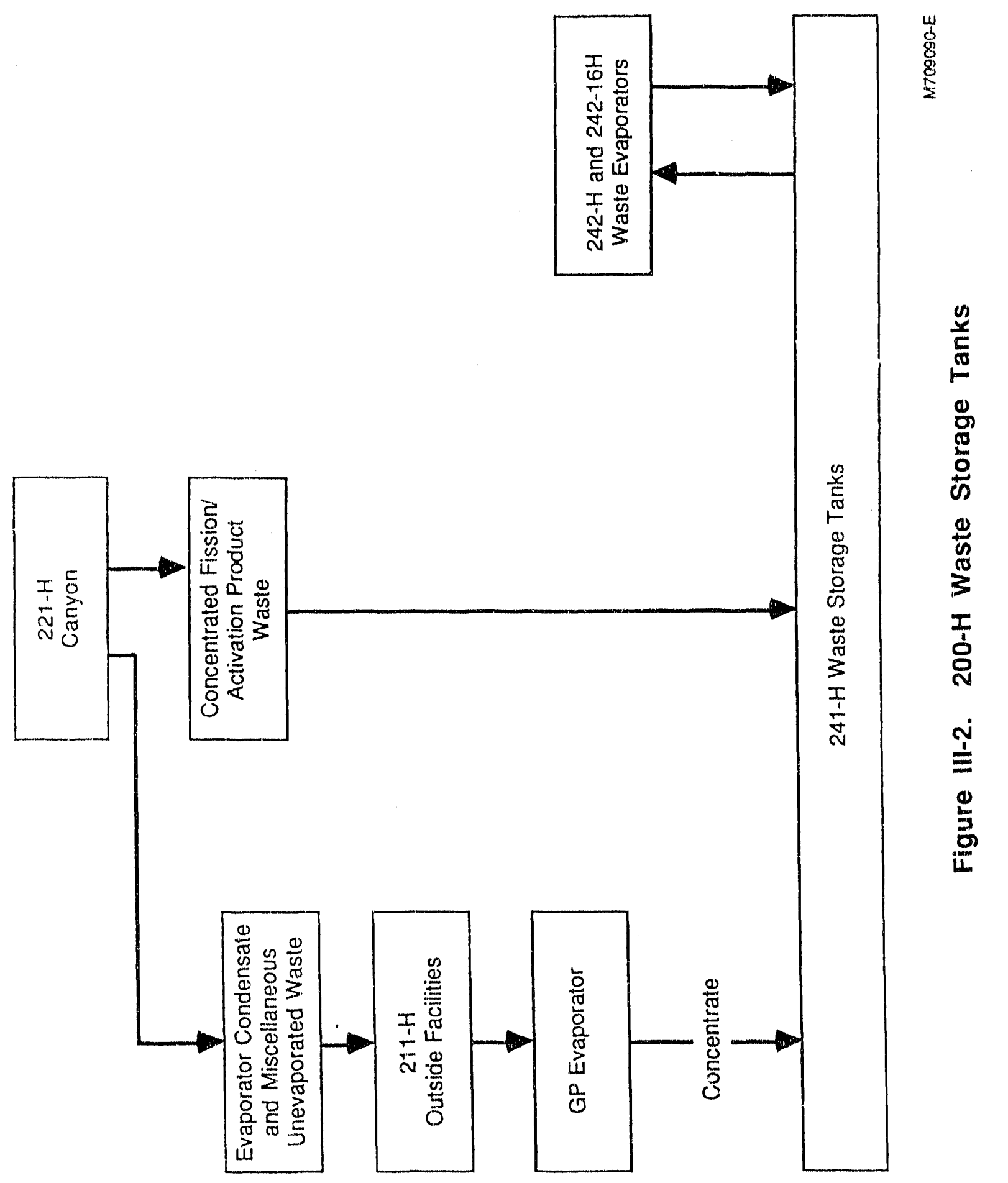




\section{High-Lovel Waste Inventory}

The volume of radioactive HLW liquid waste stored in underground storage tanks as of December 31, 1991, is shown in Table III-3.

\section{'Table III-3. HLW from Chemical Processing Operations (inventory as of 12/31/91)}

Waste Form

Volume (thousands of gallons)

Salt

Sludge

Supernate

Total

Activity (thousands of curies as of $12 / 31 / 91$ )

Total

\subsection{High-Level Waste Storage}

\section{Waste Tanks}

SRS has 51 large subsurface tanks for storing and processing aqueous high-level radioactive waste. The H-Area tank farm contains 29 of these tanks, and the F-Area tank farm contains the remaining 22 tanks. All of the tanks are built of carbon steel and reinforced concrete, but they were built with four different designs. Three designs (Types I, II, and III) have double steel walls and forced (water) cooling systems, and the fourth design (Type IV) has a single steel wall and does not have forced cooling. Type IV tanks are used for storing low-activity liquid waste.

Appendix III contains information on the construction and operating history of these tanks and the limits that have been imposed to protect them from corrosion.

\section{Technical Approach to Leaks in Waste Tanks}

Types I and II waste tanks built at SRS have been in service for over 30 years, and nine of them have leaked liquid waste from the free-standing primary tank into the secondary steel "pan" immediately below the tark. In general, the leaks in the primary tanks have resulted from hairline cracks a few inches long at or near seam welds. The cracks were induced by the high nitrate concentration in the waste solutions and residual stresses near weld sites. With one exception, Tank $16 \mathrm{H}$, the waste leaking from the primary tanks has been completely contained by the secondary pans and has not escaped into the ground. When Tank $16 \mathrm{H}$ leaked, the waste in the annulus rose above the top of the secondary pan and between 10 and 100 gallons of waste seeped into the surrounding soil through a construction joint in the concrete vault. Tanks built since the 
mid-1960s (designated Type III) have had the primary vessels stress-relieved to prevent stress cracking, and the secondary tanks are high enough to contain the full volume of the primaries. The outer walls of the primary tanks and the annular spaces between primary and secondary vessels are inspected frequently to ensure prompt detection of any new cracks which may occur or wastc leakage which may recur through existing cracks. Temperature and liquid level are monitored daily. Also, the concentration of chemical inhibitors added to the waste has been increased/ controlled to help minimize nitrate-induced stress corrosion. No Type III tanks have leaked after approximately 400 tank-years of service.

In December 1983, three penetrations were found in the $3 / 8$-inch-steel wall of Tank $20 \mathrm{H}$, a single-walled Type IV tank built in 1958. The penetrations are all above the liquid level. Groundwater monitoring wells indicated that no waste had leaked out of the tank; however, the penetrations are of concern for all the Type IV tanks because these tanks do not have secondary steel containment. If penetrations were to form beneath the liquid level in any Type IV tank, the waste could leak into the concrete encasement. Although the encasement would provide an impediment to radionuclide migration, it is not designed to contain the waste as are the annulus pans in the Types I and II tanks, or the full secondary containment in the Type III tanks. Thus, long-term storage of high-level waste in the Type IV tanks represents an unacceptable risk. More than $99 \%$ of the high-level waste has been removed from the eight Type IV tanks. Four of these tanks $(17 \mathrm{H}, 21 \mathrm{H}, 22 \mathrm{H}$, and $23 \mathrm{H})$ continue to receive dilute radioactive waste.

Because of the compromised integrity of the cracked tanks, it is planned to transfer the highlevel wastes from all pre-1964 tanks into stress-relieved Type III tanks as processing requirements permit. T'wenty-seven Type III tanks were built to accommodate the existing and future volumes of high-level waste. All of them are in service with the exception of one tank that remains empty as an emergency spare (Tank 46).

The program to retire the older tanks from service requires the capability to remove essentially all waste--supernate, salt, and/or sludge--from the tanks to be retired. Transfer of supernatant liquid from tank to tank has been done routinely for many years, utilizing steam-actuated submerged eductors (jets) and buried stainless steel pipelines encased in carbon steel jackets or concrete and transite. The technique of transferring salt and sludge from tank to tank has also been modified to use telescoping transfer pumps (TTP). Sludge was removed from seven tanks in 1966 through 1969 by a hydraulic mining and slurrying technique using once-through water at several thousand psi pressire. The practice was discontinued because so much added water was needed for thorough sludge removal that sufficient tank space to accommodate it was not available. The technique was modified to use waste supernate as the vehicle for breaking up and suspending the sludge. Several centrifugal slurry pumps were submerged in the tank being cleaned in lieu of the external pumps formerly used, which could be used only with clean water. This allows the slurrying operation to be repeated as often as necessary to suspend all the sludge without adding significantly to the waste volume. This technique was used successfully to clean two tanks, Tanks $16 \mathrm{H}$ and $17 \mathrm{~F}$, and to remove a portion of the sludge from two additional tanks, Tanks $15 \mathrm{H}$ and $18 \mathrm{~F}$. HLW was also removed from Tanks $19-20 \mathrm{~F}$ and 21,22 , and $24 \mathrm{H}$, although Tanks $21-23 \mathrm{H}$ continue to be used to receive RBOF waste and low-level wash waters. Sludge removal from Types I and II tanks is currently scheduled to continue through $20(0) 1$. 


\subsection{DESCRIPTION OF HIGH-LEVEL WASTE TREATMENT FACILITIES}

Processes that treat radioactive liquid waste routinely are evaporation and ion exchange. The evaporator overheads are treated in cesium removal columns (CRCs) before being transferred to the Effluent Treatment Facility, which became operational in October 1988. In addition, processes were developed to treat HLW to prepare it to be fed to the DWPF. (See sludge processing and salt processing information later in this section.)

\section{Tank Farm Evaporators}

Each waste tank farm ( $\mathrm{F}$ and $\mathrm{H}$ ) has two single-stage, bent-tube evaporators that are used to concentrate alkaline waste following receipt from the canyons. Waste that is higher in radioactivity is segiegated and allowed to age before evaporation. The aging allows separation of the sludge and supernate and also allows the shorter-lived radionuclides to decay to acceptable levels. Alkaline waste is also being segregated into low ruthenium waste and high ruthenium waste for processing in DWPF. The 242-F, 242-16F, and the 242-16 $\mathrm{H}$ evaporator systems process the low ruthenium waste; and the $242-\mathrm{H}$ evaporator system processes high ruthenium waste. Radioactive waste, as received and stored in the tank farms, can be reduced to about 20 and $25 \%$ of its original volume and immobilized as crystallized salt by successive evaporations of the liquid supernate. Such a dewatering operation has been carried on routinely in F Area since 1960 and in H Area since 1963. This operation is shown schematically in Figure III-3. Evaporator throughput and space recovered are shown in Table III-4. Since the first evaporator facilities began operation in 1960 , more than $103,401,(0)()$ gallons of space has been reclaimed. Eighty-two additional waste tanks valued at more than $\$ 33$ million each would have been required to manage this waste had evaporation not been used. The design and construction of the evaporators are described in Appendix 1.

\section{Cesium Removal Columns}

Each tank farm evaporator has a cesium removal column (CRC) located in a riser through the top of a waste storage tank. These columns are used to remove cesium from the condensate that results from the concentration of waste supernates (Figure III-4). In addition, one of the columns in H Area is used to remove cesium from aqueous wastes discharged by the resin Regeneration Facility (RRF) and the receiving basin for offsite fuel (RBOF). When the Evaporator overheads are above a prescribed radioactivity level, they are sent through the CRC to further reduce the Cs-137 content. If the Cs-137 concentration in the overheads is still above the prescribed level, the waste stream is recycled for additional evaporation. The evaporators achieve a condensate decontamination factor of greater than $10^{4}$. CRCs ion exchange resin can provide a decontamination factor for Cs- 137 of up to 20() . The cesium removal column effluent is sent to a hold tank where it is sampled, and, if the concentration is acceptable, the processed condensate is sent to the Effluent Treatment Facility. It maly also be sent to a waste tank. CRCs are described in Appendix II. 
Savannah River Site Interim Waste Management Program Plan
III. Radioactive and Mixed Waste Management

May 1992

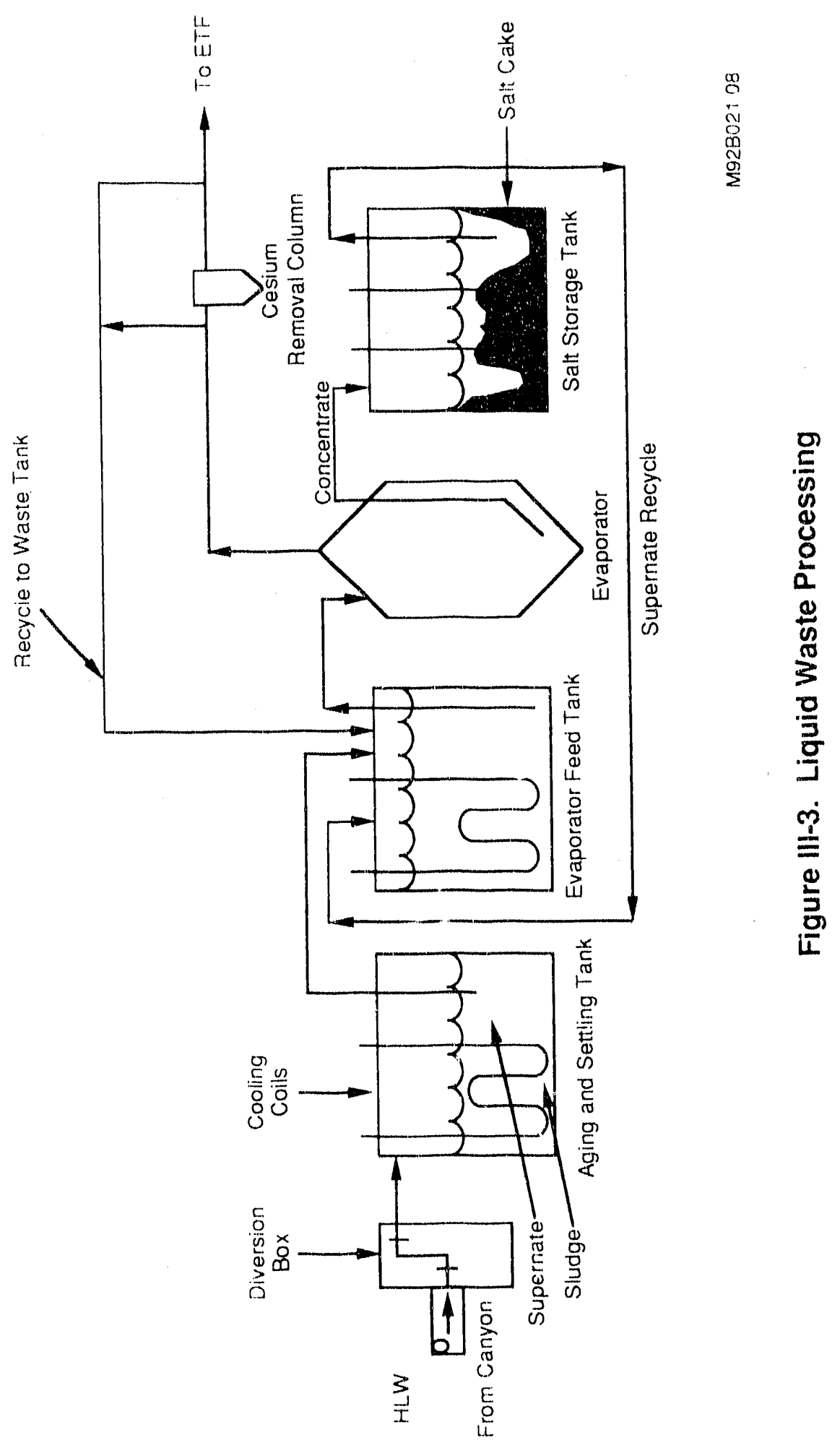


Table III-4. Tank Farm Evaporator Utilization (measured in thousands of gallons)

\begin{tabular}{|c|c|c|c|c|c|c|c|c|c|}
\hline \multirow{2}{*}{$\begin{array}{l}\text { Calcendar } \\
\text { Year } \\
\end{array}$} & \multicolumn{3}{|l|}{ F. Arca } & & \multicolumn{3}{|l|}{ Tolal } \\
\hline & Fecd, & Conc, b & $\begin{array}{l}\text { Space } \\
\text { Gain, }\end{array}$ & Fcad & Conc. & $\begin{array}{l}\text { Space } \\
\text { Gain } \\
\end{array}$ & Foed & Conc. & $\begin{array}{l}\text { Space } \\
\text { Gain }\end{array}$ \\
\hline $3 / 6(0) .8 / 61$ & 3,360 & 982 & 2,378 & - & - & - & 3,360 & 982 & 2,378 \\
\hline $9 / 61-1 / 62$ & 1,101 & 283 & 818 & - & - & - & 1,101 & 283 & 818 \\
\hline $2 / 62-12 / 62$ & 3,365 & 994 & 2,371 & - & - & - & 3,365 & 994 & 2,371 \\
\hline 1963 & 2,818 & 809 & 2,009 & 1,669 & 584 & 1,085 & 4,487 & 1,393 & 3,094 \\
\hline 1964 & 4,250 & 2,006 & 2,244 & 437 & 38 & 399 & 4,687 & 2,044 & 2,643 \\
\hline 1965 & 2,590 & 1,452 & 1,138 & 2,778 & 837 & 1,941 & 5,368 & 2,289 & 3,079 \\
\hline 1966 & 2,366 & 986 & 1,380 & 3,880 & 1,406 & 2,474 & 6,246 & 2,392 & 3,854 \\
\hline 1967 & 2,593 & 1,355 & 1,238 & 3,084 & 1,381 & 1,703 & 5,677 & 2,736 & 2,941 \\
\hline 1968 & 4,010 & $2,(0) 9$ & 1,879 & $5,(127$ & 2,345 & 2,467 & 9,037 & 4,354 & 4,346 \\
\hline 1969 & 4,627 & 2,755 & 1,643 & 5,971 & 3,008 & 2,821 & 10,598 & 5,763 & 4,464 \\
\hline 1970 & 4,953 & 2,549 & 2,262 & 4,934 & 1,769 & 3,081 & 9,887 & 4,318 & 5,343 \\
\hline 1971 & 4,332 & 2,199 & $2,(021$ & 4,640 & 1,817 & 2,733 & 8,972 & 4,016 & 4,754 \\
\hline 1972 & 4,106 & 2,562 & 1,475 & 5,499 & 3,795 & 1,637 & 9,605 & 6,357 & 3,132 \\
\hline 1973 & 5,933 & 3,846 & 1,968 & 7,914 & 5,744 & 2,114 & 13,847 & 9,590 & 4,082 \\
\hline 1974 & 5,971 & 3,860 & 1,676 & 8,279 & 6,792 & 1,081 & 14,250 & 10,652 & 2.757 \\
\hline 1975 & 1,835 & 961 & 684 & 1,721 & 1,310 & 247 & 3,556 & 2,271 & 931 \\
\hline 1976 & 1,857 & 1,030 & 780 & 4,315 & 2,962 & 1,106 & 6,172 & 3,992 & 1,886 \\
\hline 1977 & 1,594 & 880 & 552 & 1,568 & 1,219 & 269 & 3,162 & 2,099 & 821 \\
\hline 1978 & 2,739 & $1,7(04$ & 339 & 4,086 & 2,807 & 1,330 & 6,825 & 4,511 & 1,889 \\
\hline 1979 & 2,171 & 1,270 & 632 & 2,689 & 1,801 & $760)$ & $4,860)$ & 3,071 & 1,392 \\
\hline 1980 & 7,186 & 4,477 & 2,258 & 1,307 & 873 & 269 & 8,493 & 5,350 & 2,527 \\
\hline 1981 & 12,712 & 9,164 & 2,950 & 5,140 & 3,450 & 1,317 & 17,852 & 12,614 & 4,267 \\
\hline 1982 & 7,679 & 5,364 & 1,900 & 8,105 & 4,513 & 2,875 & 15,784 & 9,877 & 4,775 \\
\hline 1983 & 11,974 & 9,135 & 2,197 & 9,350 & 4,607 & 4,347 & 21,325 & 13,742 & 6,544 \\
\hline 1984 & 4,938 & 3,268 & 1,496 & 541 & 289 & 240 & 5,479 & 3,557 & 1,736 \\
\hline 1985 & 15,394 & 11,172 & 3,684 & 7,940 & 4,530 & 2,996 & 23,334 & 15,702 & 6,680 \\
\hline 1986 & $18,(0) 3$ & 14,536 & 3,462 & 13,091 & 9,996 & 3,062 & 31,094 & 24,532 & 6,524 \\
\hline 1987 & 18,518 & 14,859 & 3,085 & 9,671 & 7,177 & 1,910 & 28,189 & 22,036 & 4,995 \\
\hline 1988 & 11,526 & 9,878 & 1,233 & 8,919 & 6,141 & 2,233 & 20,445 & 16,019 & 3,466 \\
\hline 1989 & 5,006 & $4,4(1) 2$ & 558 & 3,943 & 2,141 & 1,721 & 8,949 & 6,543 & 2,279 \\
\hline 1990 & 3,196 & 2,832 & 363 & 1,638 & 937 & 648 & 4,834 & 3,769 & 1,011 \\
\hline $1 / 91-11 / 91$ & 3,151 & $2,8(0) 3$ & 337 & 2,727 & 1,429 & 1,284 & 5,878 & 4,232 & 1,622 \\
\hline Total & 185,854 & 126,382 & $53,230)$ & $140,86.3$ & 83,708 & 5()$, 170)$ & 326,717 & $212,(590$ & $103,4(0)$ \\
\hline
\end{tabular}

a Based on feed lank depletion and known (or estimated) reccipts into feed tank, including flushes, bottoms, and reject streams routed to feed tank from cvaporalor and CRC.

b Based on boutom tank accumulation, including descaling and flush watcr, and lift and bleed steam added to concentrate receiving tank. Also includes estimated volume of evaporator bottom discharge directly to feed tank, if any.

c. Through 1967, evaporator space gain was laken as total feed minus total concentrate produced, i.c., *.**. This in effece counted recycled off-specilication overheads as new evaporator feed and gave a falsely high space gain figure. Beginning in 1968, the error cited in ta was corrected. Beginning in 1974, additional correction was made to exclude from net space gain water added elsewhere in evaporator system (c.g., transfer jet dilution enroute to feed lank, CTS vent condensate, cte.) 


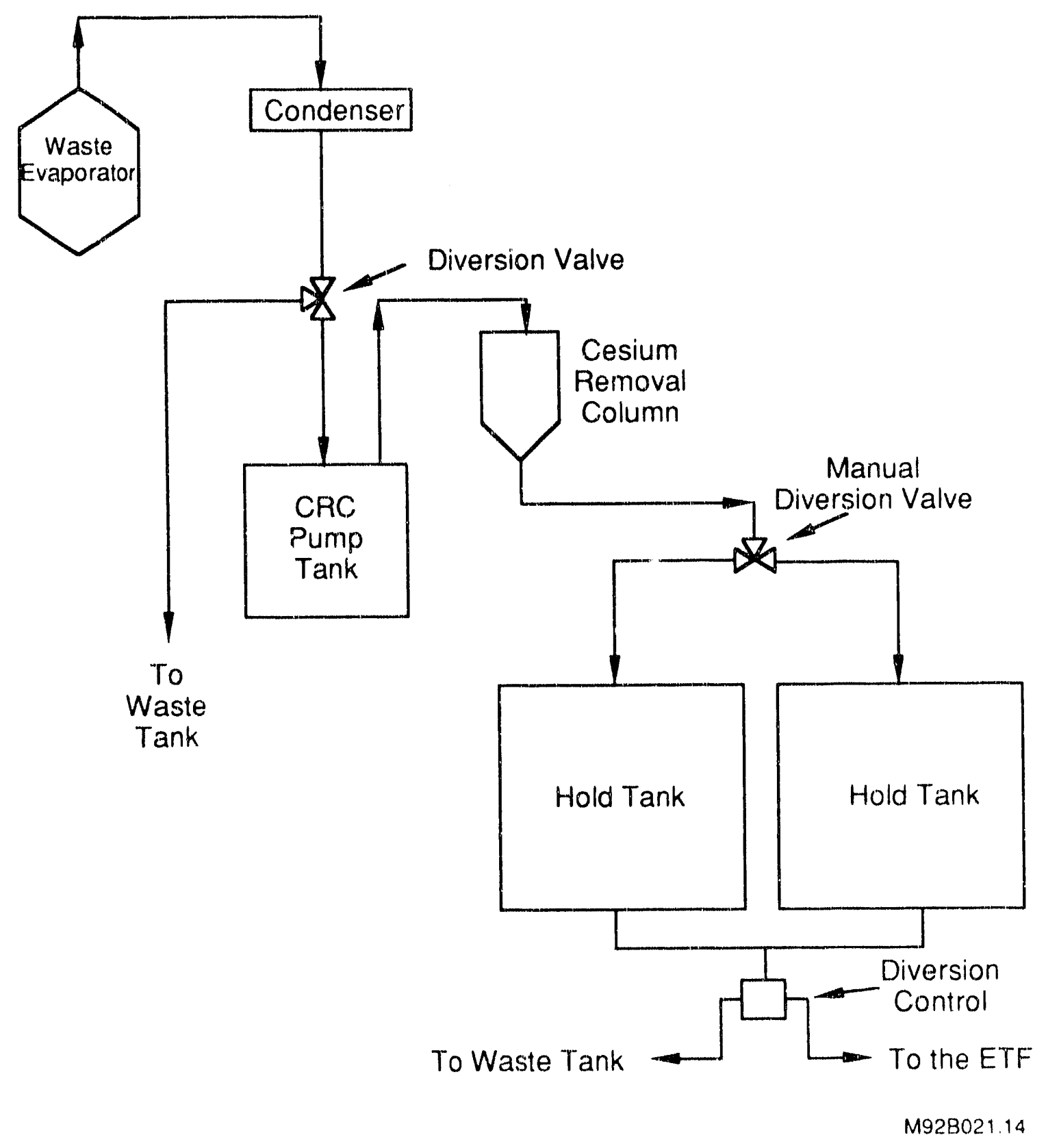

Figure III-4. Cesium Removal from Waste Evaporator Condensate 


\subsection{High-Level Waste Transfer and Processing}

The immediate objectives of the HLW Transfer and Processing Program are to: 1) transfer radioactive waste, including liquid, salt, and sludge, from the first three generations of waste tanks (Types I, II, and IV) into newer Type III tanks and 2) maintain space in the tank farm for fresh waste receipts from the separations facilities by removing salt cake stored in Type III concentrate receipt tanks. The long-term objective is to prepare this waste (and eventually the remainder of the waste in the Type (II tanks) for feed to the DWPF. The waste removal program includes removal of salt and sludge by mechanical agitators, spray washing the tank interior wall, and steam/water cleaning the tank annuli. The waste processing program includes decontamination of the salt and liquid for incorporation into saltstone and aluminum dissolution and washing the sludge for feed to the DWPF. The schedules of waste transfer and waste processing are closely linked with each other and with the DWPF schedule.

Processes and equipment for waste removal and waste processing were developed and demonstrated. Sludge removal by hydraulic slurrying and chemical cleaning with oxalic acid were demonstrated in Tank $16 \mathrm{H}$. Salt removal and sludge removal using mechanical agitation were demonstrated. Facilities in subsequent tanks for salt removal, sludge removal, and chemical cleaning were designed using data and experience gained from these demonstrations. To date, 3.4 million gallons of salt and 1.1 million gallons of sludge have been removed from Types I, II, and IV waste tanks.

The sludge and salt processing techniques were demonstrated in Tanks $42 \mathrm{H}$ and $48 \mathrm{H}$, respectively. Normal operatior of extended sludge processing began in Tank 42H late in CY 87 and was suspended in mid-1988 for equipment modifications. A general flow diagram for the Tank Replacement/Waste Transfer Program is shown in Figure III-5. The quantity of salt and slucige to be transferred to new tanks is shown in Table III-3.

To assist Waste Management with the Salt Removal Process, a new control systern will be added to Building $241-18 \mathrm{~F}$, and an upgraded control system will be added to $241-82 \mathrm{H}$. The control system consists of an operator's console, maintenance console, and support peripherals. Both the operator and maintenance consoles will have the ability to function as the online console at the same time. The console that is not performing control will be able to monitor the logic executed in buth the Instrument Control Room (ICR) and field units.

The automated system's major functions are process control, providing information to the operator, alarming, information gathering (e.g., shift report), data plotting, and record keeping.

\section{Salt Processing}

To eliminate the need for additional salt storage tanks, aged salt will be decontaminated for disposal as saltstone. The ITP waste decontamination process uses sodium tetraphenylborate to frecipitate cesium and sodium titanate to adsorb strontium and plutonium from the waste supernate as shown in Figure III-6.

The resultant slurry is then pumped through a complex microfiltration process that yields a high activity precipitate stream and a low-activity filtrate stream. The precipitate stream $(99.9 \%$ of the radioactivity, $10 \%$ of the volume) is then transferred to DWPF for incorporation into a borosilicate 
Savannah River Site Interim Waste Management Program Plan
III. Radioactive and Mixed Waste Management May 1992

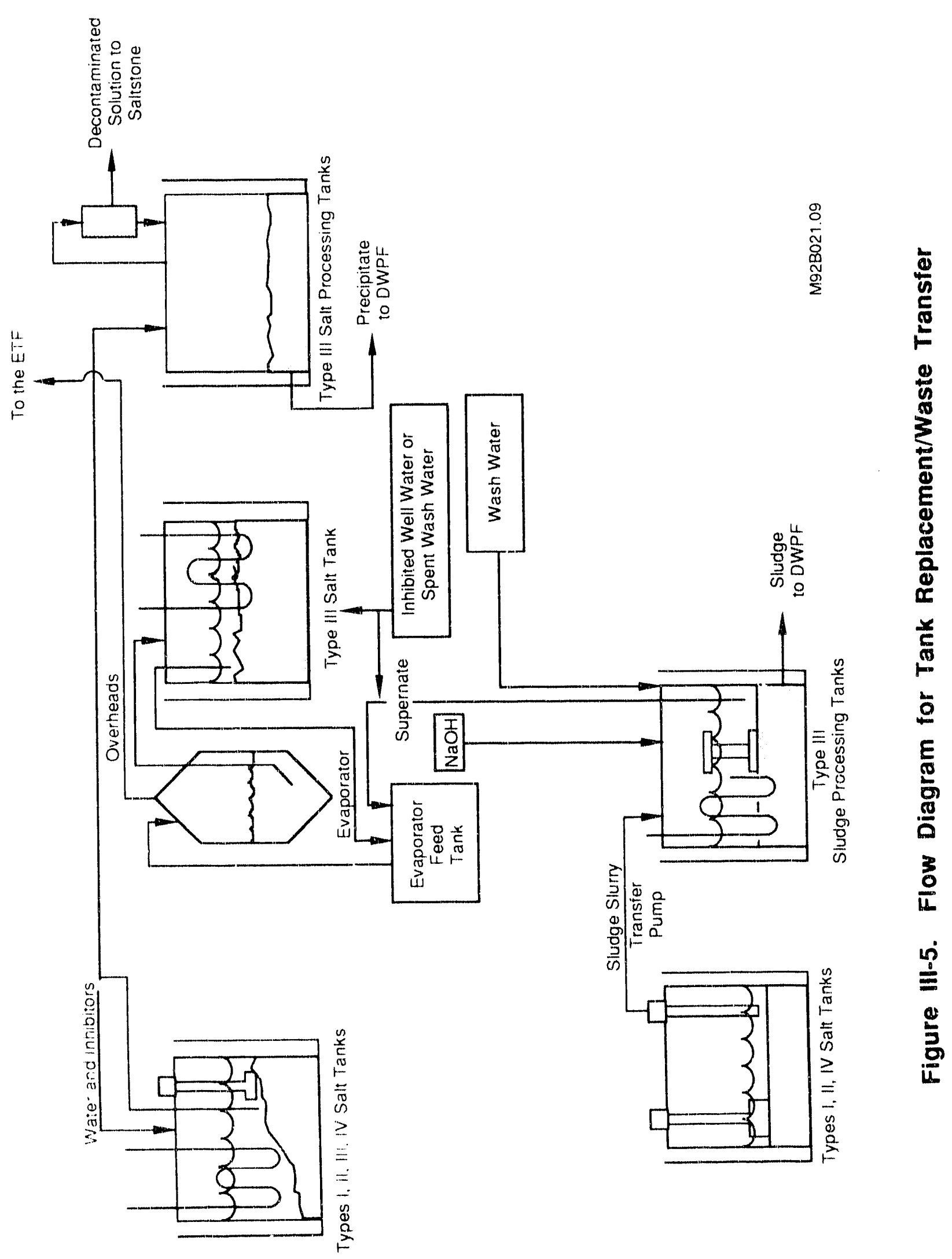




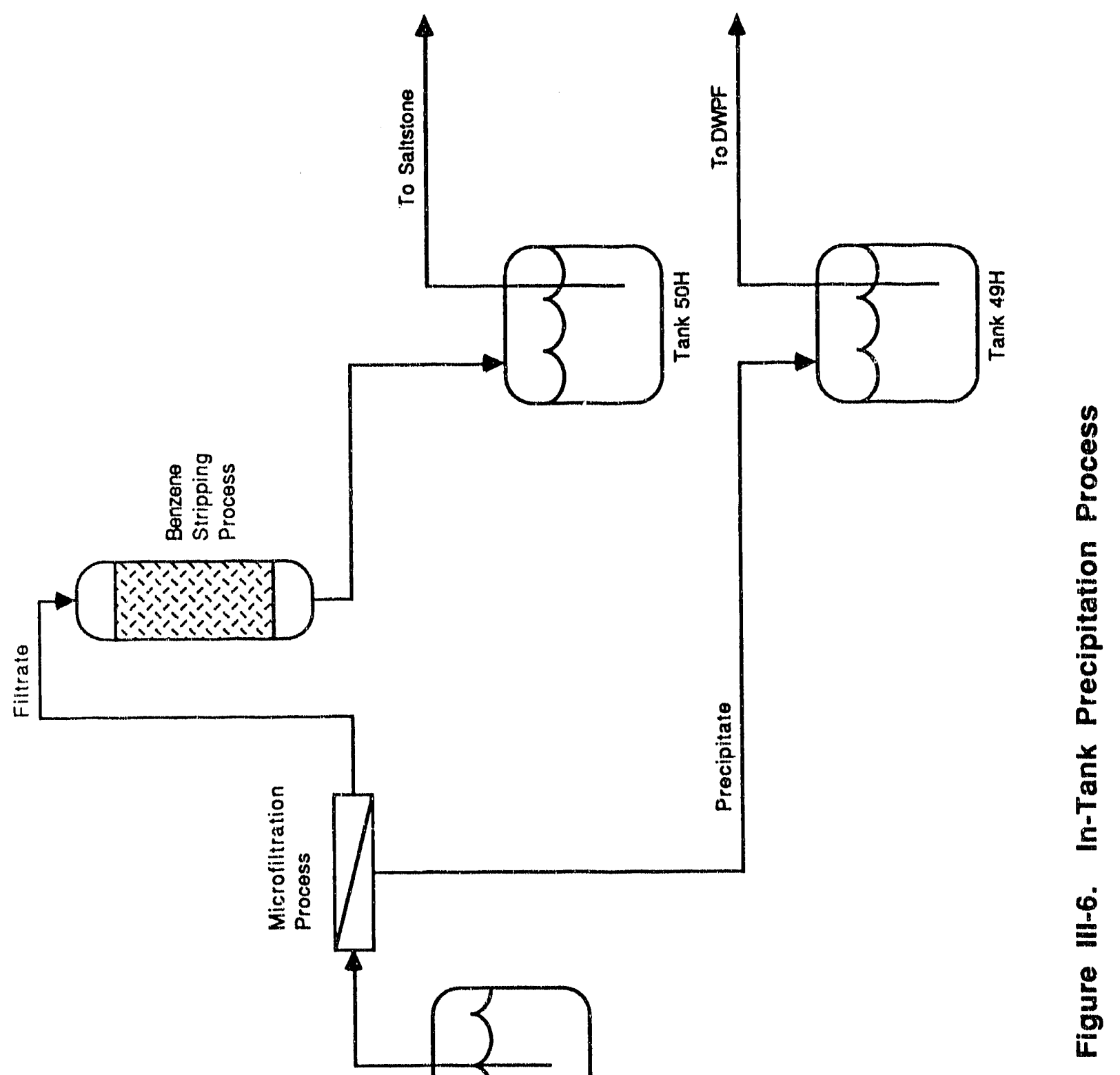


glass waste form. The filtrate stream ( $0.1 \%$ of the radioactivity, $90 \%$ of the volume $)$ is transferred to saltstone for incorporation into a cement, slag, and flyash-based wasteform.

A plant-scale demonstration of the ITP process was successfully completed in Tank $48 \mathrm{H}$ between January and April of 1983 using a half-million-gallon batch of radioactive salt solution from Tank $24 \mathrm{H}$. The filtrate from the demonstration was used for a demonstration of saltstone production and disposal.

In late 1987, continuing development work established that the organic chemicals used to decontaminate the salt solution posed a flammability concern in the processing tanks and at the cold feed storage area. In addition, it was also deternined that the amount of organics (specifically benzene) in the filtrate to be sent to Saltstone was unacceptable in light of proposed changes in environmental laws. A new project designed to provide environmental and safety enhancements to the ITP process was undertaken. The enhancement project provides nitrogen inerting of the processing and cold feed tanks and a benzene stripper for the filtrat ${ }^{*}$.

This process will eventually decontaminate 1.5 million gallons of saltcake annually. At this rate, processing will become current with waste receipts after approximately 15 years of operation. Demonstration experience is being used as the basis for design of long-term processing facilities.

ITP must interface with salt removal and saltstone production. Salt removal will be scheduled properly to provide a continuous source of feed for In-Tank Precipitation, which, in turn, provides feed for Saltstone production. Salt removal must also be scheduled to maintain space in the salt receivers and to allow sufficient aging of the salt in the tank farm so that key radionuclides can decay to acceptable levels.

\section{Sludge Processing}

To prepare the sludge for DWPF, some of it will be treated with $\mathrm{NaOH}$ to dissolve aluminum oxides, and all of it will be water washed to remove soluble solids.

A full-scale demonstration of the process was successfully completed in Tank $42 \mathrm{H}$ during FY $82-83$. About $77 \%$ of the aluminum and $>98 \%$ of the soluble salts were removed from a 125,000 -gallon batch of sludge from Tank $15 \mathrm{H}$. The upgraded facility for full-scale processing will use Tanks $40 \mathrm{H}, 42 \mathrm{H}$, and $51 \mathrm{H}$. Tank $42 \mathrm{H}$ is used for aluminum dissolution and sludge washing. Tanks $40 \mathrm{H}$ and $51 \mathrm{H}$ will be used alternately for sludge washing and feeding DWPF. Using two tanks at a time for sludge washing significantly reduces the water needed (Figure III-7) because the spent wash water from the first tank can be reused in the second.

Sludge processing began in Tank $42 \mathrm{H}$ in March 1987. The program is currently suspended to correct recurrent slurry pump seal water contamination problems. Plans are for each slurry pump to be modified to prevent future contamination incidents prior to resuming operations. Sludge processing will be scheduled in conjunction with sludge removal to facilitate the use of common equipment and to provide feed for the waste vitrification facility. 


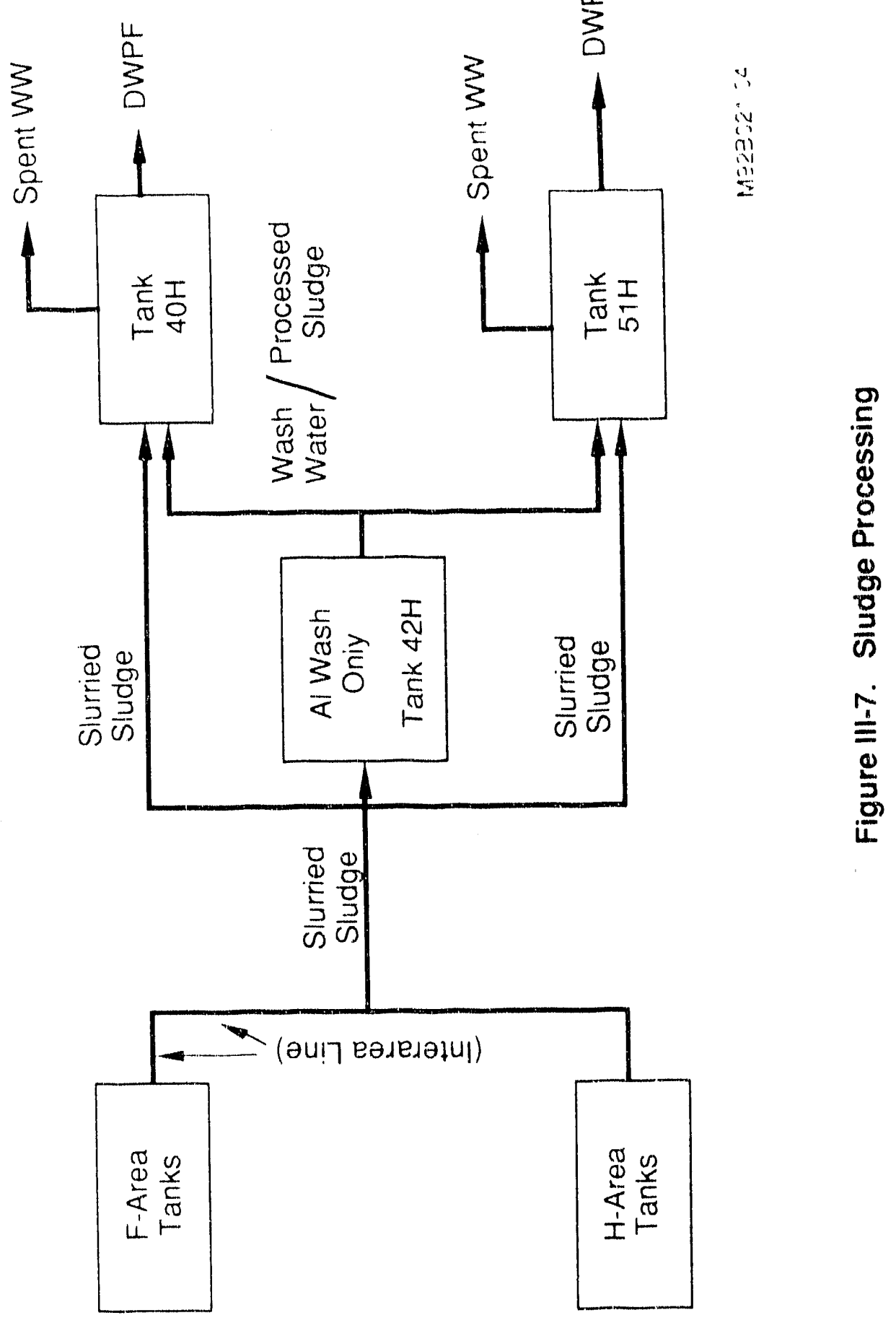




\section{Annulus Cleaning and Zeolite Removal}

Salt solution has leaked into the annuli of nine waste tanks; five are Type I tanks and four are Type II tanks. Annulus cleaning, using hot water washes and steam lances, was demonstrated in Tank $16 \mathrm{H}$; about $50 \%$ of the waste and $70 \%$ of the activity were removed from the annulus. Annulus cleaning using oxalic acid washes will be demonstrated in Tank $16 \mathrm{H}$ following the completion of sludge removal from Tank $15 \mathrm{H}$. Based on the siccessful demonstration, equipment will be installed to remove waste from the annuli using hot water and/or oxalic acid washes. The annuli of the Type I tanks will be flushed to check for leaks not previously detected.

A test in Tank 24H, completed in August 1983, showed that the spent zeolite could not be effectively removed with agitation alone, as is done for sludge removal. Two washes in Tank $24 \mathrm{H}$, with $8 \mathrm{wt} \%$ oxalic acid, have removed an estimated $23 \%$ of the activity and $36 \%$ of the solids. Tanks $19 \mathrm{H}$ and $24 \mathrm{H}$ may be cleaned at a later date if a practical method for removing the zeolite can be demonstrated.

\section{Implementation of Waste Transfer and Processing}

Attainment of the program goal to remove and process waste from 22 of the original Types I, II, and IV tanks required the sequential achievement of a number of secondary program goals involving SRS, SRL, and the design agencies. SRL developed chemistry standards to prevent corrosion in the DWPF feed tanks for sludge and precipitate; these standards called for the addition of inhibitors to these tanks, and refinements are being studied in the DWPF processes to handle the new inhibitors. Samples from ongoing waste removal will be analyzed extensively to allow more complete characterization of tank contents, and other tanks are being sampled selectively to answer specific questions. SRS personnel will continue to work closely with the design agencies to ensure that waste removal and sludge and salt processing facilities are expeditiously constructed.

Waste removal operations are to be performed in such a manner that normal containment of radioactivity is maintained, and releases to the environment are minimized. Process conditions will be maintained to prevent any physical damage to waste tanks due to corrosion or mechanical accident.

After waste removal and chemical dissolution, the storage tanks are expected to contain some radioactivity in residual heels, metallic scale, and insoluble deposits. However, the potential for radioactive liquids to leak from the tanks will have been essentially eliminated. The emptied tanks will be in a suitable condition for further cleaning, if necessary, or to be altered for other use or decommissioning.

The time schedule for waste removal not only must align with the schedule to provide feed for the DWPF, but must also be flexible and subject to adjustment based on SRS experience, SRL development studies, funding availability, and changing conditions. The schedule is also dependent on operating conditions in existing waste storage facilities, startup, and projected fecdrate, as well as current waste receipts. 
Process and equipment development in support of salt removal, sludge removal, and chemical cleaning is essentially complete. Design of sludge processing facilities required development of instruments for locating the sludge/supernate interface and measuring supernate conductivity. Prototype instruments were tested during the sludge processing demonstration, but refinements are required to lengthen their service life.

The majority of SRL development work for the HLW Transfer and Processing Program was directed at the salt decontamination process and chemistry standards for the DWPF processing tanks. Technical data developed by SRL, along with results from the plant-scale demonstration, have been used for design of long-term processing equipment.

\subsection{Current and Future Plans}

In addition to the current and future plans associated with the processing of high-level liquid waste, as noted in Section III.A.4.(), new facilities and facility upgrades are also scheduled for the tank farms. A few of the major projects scheduled are described in this section.

\section{Replacement of the HLW Evaporator}

This project will provide an evaporator system that will concentrate high-and low-level liquid radioactive waste to reduce the required storage volume. This evaporator will help to ensure that the materials production and waste solidification facilities at SRS are not limited by waste storage volume. The evaporator will replace the $242-\mathrm{H}$ evaporator and allow the $242-\mathrm{F}$ evaporator to be placed in a standby mode. The replacement evaporator will increase waste concentration and contamination control, reduce radiation exposure to personnel, and reduce operating costs.

The operation of the Defense Waste Processing Facility and the preparation of DWPF feed within the waste tank farm will produce over four million gallons of dilute LLW annually. The replacement high-level waste evaporator (RHLWE) will allow the tank farm to continue receiving canyon waste streams even with receipt of this considerable amount of new waste.

The new evaporator, which is scheduled to be on line by 1996 , is currently in the design stage; it is estimated to reduce operating costs by $\$ 3.6$ million each year. The RHLWE is described in Appendix I.

\section{Tank Farm Control System and New Control Room Plan}

Type III Tank Salt Removal, Phase II, will provide facilities to safely remove radioactive salt from Tanks $31 \mathrm{H}$ and $47 \mathrm{~F}$ beginning in 1996. In addition, sludge will be removed from Tank $47 \mathrm{~F}$. This waste must be removed on a schedule that permits continued receipt of fresh waste and that also satisfies the processing requirements of ITP, Extended Sludge Processing (ESP), and DWPF. Resulting salt solutions will be processed in the ITP Facility, and sludge solutions will be processed in the ESP Facility before treatment at the DWPF. These facilities are considered permanent and will be used over the life of these tanks ( 50 years). 


\section{Savannah River Site Interim Waste Management Program Plan}

\section{Radioactive and Mixed Waste Management May 1992}

This project is an integral step in Waste Management's strategy for Tank Farm Control (Figures III-8 and III-9). The project will provide a new control building (241-2H) and ECR/ICR (241$135 \mathrm{H}$ ) to service existing and future waste management facilities on the "old hill" (the area containing tanks 29-32 and 35-37) in II Area. A distributed control system (DCS) will be provided in the control building to monitor and control H-Area Tanks 29-32, 35-37, and all related tank farm support facilities such as pump pits, pump houses, diversion boxes, and storm water monitors. The system will : designed with sufficient capacity to expand and perform major control functions for all currently wentified future "old hill" projects (RHLWE, HLLW Processing Tanks). A DCS will also be provided to monitor and control F-Area Tanks 26, 27, 33, 34, 44-47, and the related tank farm support facilities in the $241-18 \mathrm{~F}$ control building expansion. Finally, a DCS will be provided to replace the existing CLASSIC System installed in the $241-82 \mathrm{H}$ control room to monitor and control the ESP Tanks 40, 42, and 51, ITP Tanks 48, 49, and 50, Tank 41, and all related support facilities such as cold feeds, low-point drain tanks, filter buildings, and the Nitrogen Purge/Benzene Stripping Facility.

\section{H-Area Diversion Box 7 (HDB-7) Containment Building}

To support increased waste transfers associated with salt removal, sludge removal, and DWPF startup, various routine jumper changes will have to be made in HDB-7. To be able to perform these changes in inclement weather, to reduce exposure to personnel, and to improve contamination containment, containment buildings will be built over HDB-7 and its associated pump pits (5 and 6).

These containment buildings will be equipped with overhead cranes that will run the full length of the buildings. This project should be completed by 1994 .

\section{New Waste Transfer Facility}

The New Waste Transfer Facility (NWTF) is located near the south side of the H-Area tank farm. The NWTF will replace another facility (HDB2), located 300 feet north of it, by providing for the transfer of radioactive slurries and solutions in $H$ Area. It will also serve as the receipt point for recycle waste transfers from the DWPF.

The NWTF will contain four pump pits (HPP 7-10) and one diversion box (HDB8) in a steelframe structure with an insulated, built-up roof and non-insulated metal siding for the high bay and low bay. The high bay enclosure will be 47 feet wide, 165.5 feet long, and 42 feet high, and will contain the four pump pits and one diversion box. It will be equipped with a top-running 20-ton/3ton traveling bridge crane and a one-ton monorail. The enclosed area will include space for a 40foot flatbed trailer. The low bay will contain the local instrumentation, field operations station, crane control room, electric control room, battery room, eyewash station, storage room for protective clothing and supplies, and the health protection monitoring system. The small concrete crane operator's room with shield windows will provide viewing and shielding for personnel during pump pit maintenance operations. Two CCTV monitors in the room will provide viewing of in-the-pit operations through the use of two portable cameras on manually positioned dollies.

The pump pits and diversion box will be the lowest points in the pipeline systems they will serve, and are the drain points for all the lines except the DWPF recycle waste, which drains to the auxiliary pump pit. In addition to the DWPF recycle waste stream, there are three waste streams 
Savannah River Site Interim Waste Management Program Plan

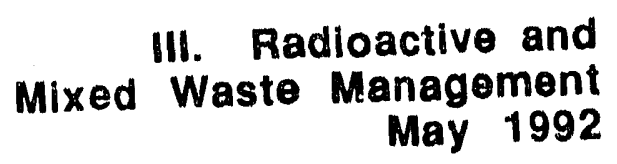

SPVTHOL-18QQM 241-18F

5. Yy falchemoval, Phase II S-2860

[i.d] Salt Remuval, Phase I S-3291

W. Luporator Instrument Upgrades, 242-16F S-3233

DS5 1) Data Acquisition System, 241-F S-3937

[-] Waste Removal S-2081
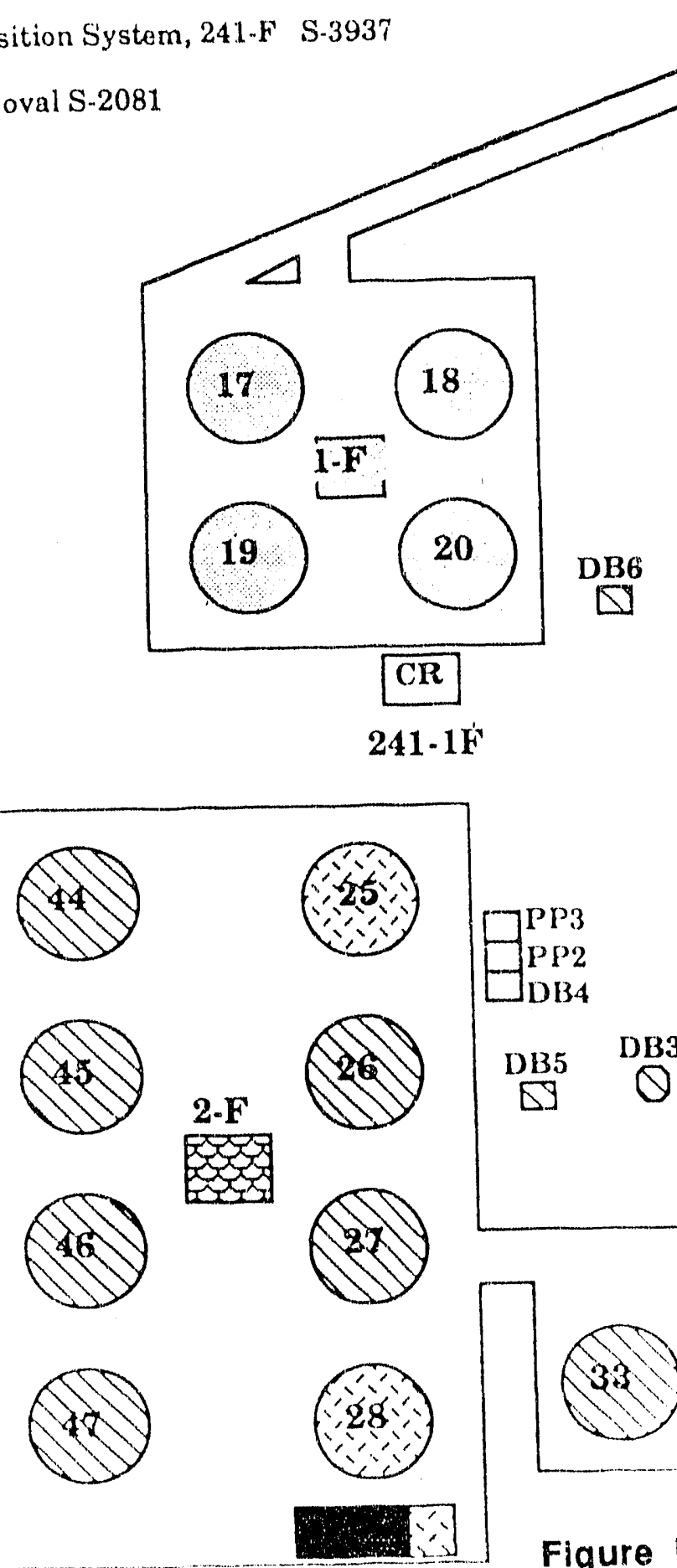

$241-18 \mathrm{~F}$

CII

$\square^{P P 3}$

PP2

$\square \mathrm{DB4}$

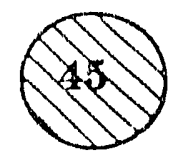

DB5 DB3

DBI
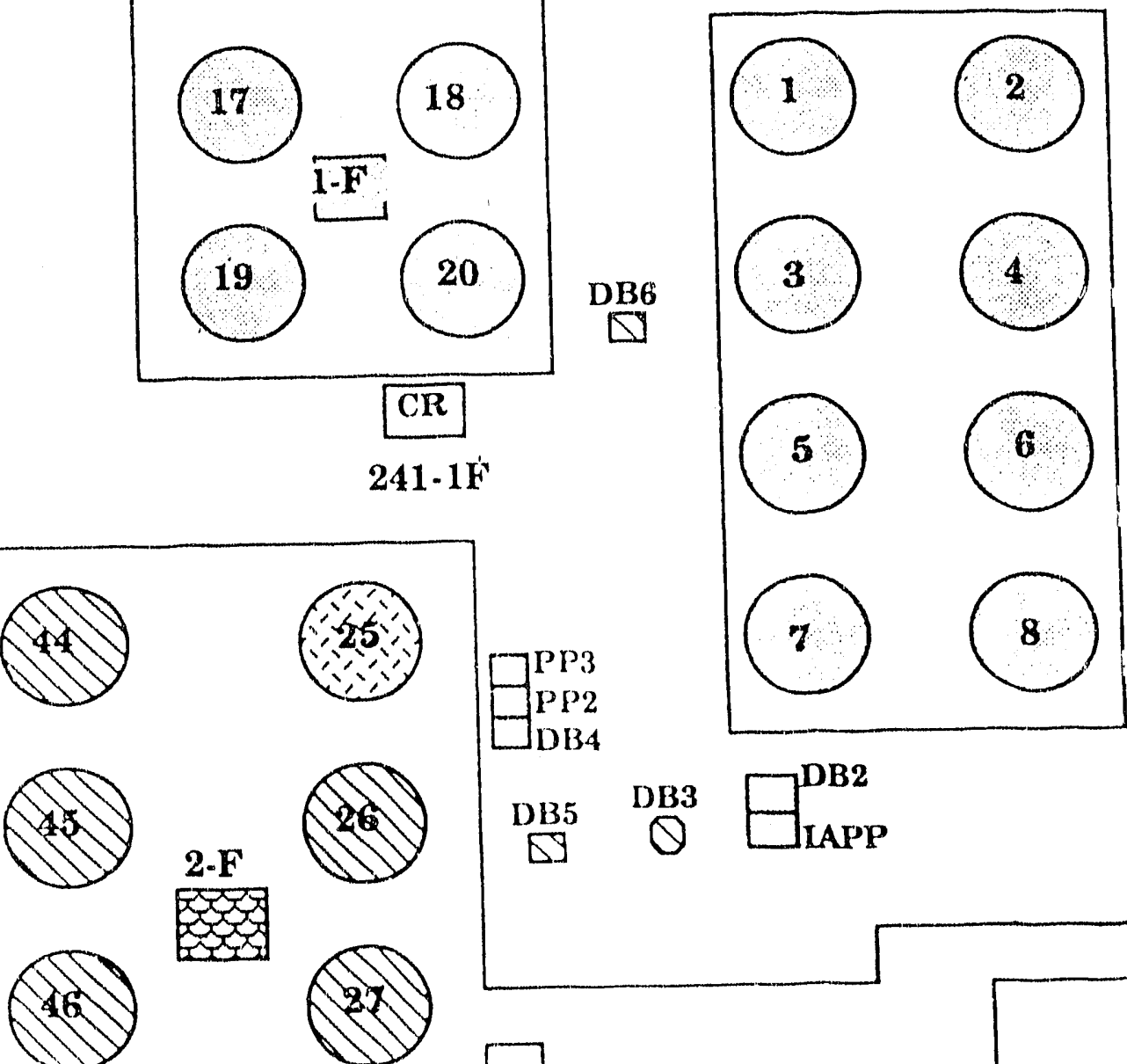

$\triangle \quad Q \quad$ LAPP

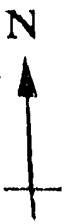

2.
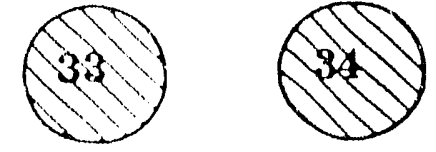

Figure III-8. F-Area 
Savannah River Site Interim Waste Management Program Plan
III. Radioactive and

Mixed Waste Management

May 1992
OWD HWL NEW CONTROLROOM

[i]1] Lcw Livel Wasto Processing Tanks S-2859

\】 Salt Removal, Phase II $\quad 8-2860$

[W] S-4062 RHLWE

\section{CONTHOL ROONLi41.1E}

Wla Evaporator Instrument Upgrade, 242-1H - S.2282

\section{CONTROL KOOMTEL-S2H}

Additional Evaporator Instrumentation, 242-16H S-2869

[ Control Room Upgrades, 241-H S-4003

E.*. Extended Sludge Processing $\mathrm{S}-2081^{*}$

$\square$ In Tank Precipitation S-3781*

EZ N2 Purge/Benzene Stripper S. $1588^{*}$

ETank 41 Salt Removal S-3782*

Low Point Pump Pit S.1780*

匀 HDB-8 S-3122

Data Acquisition System, 241-H S-2232

Control Ronm Expansion S.2463

Classic

Replacement

* The Classic Systems computer control for these facilities will be upgraded by Project S-2860 Salt Removal, Phase II

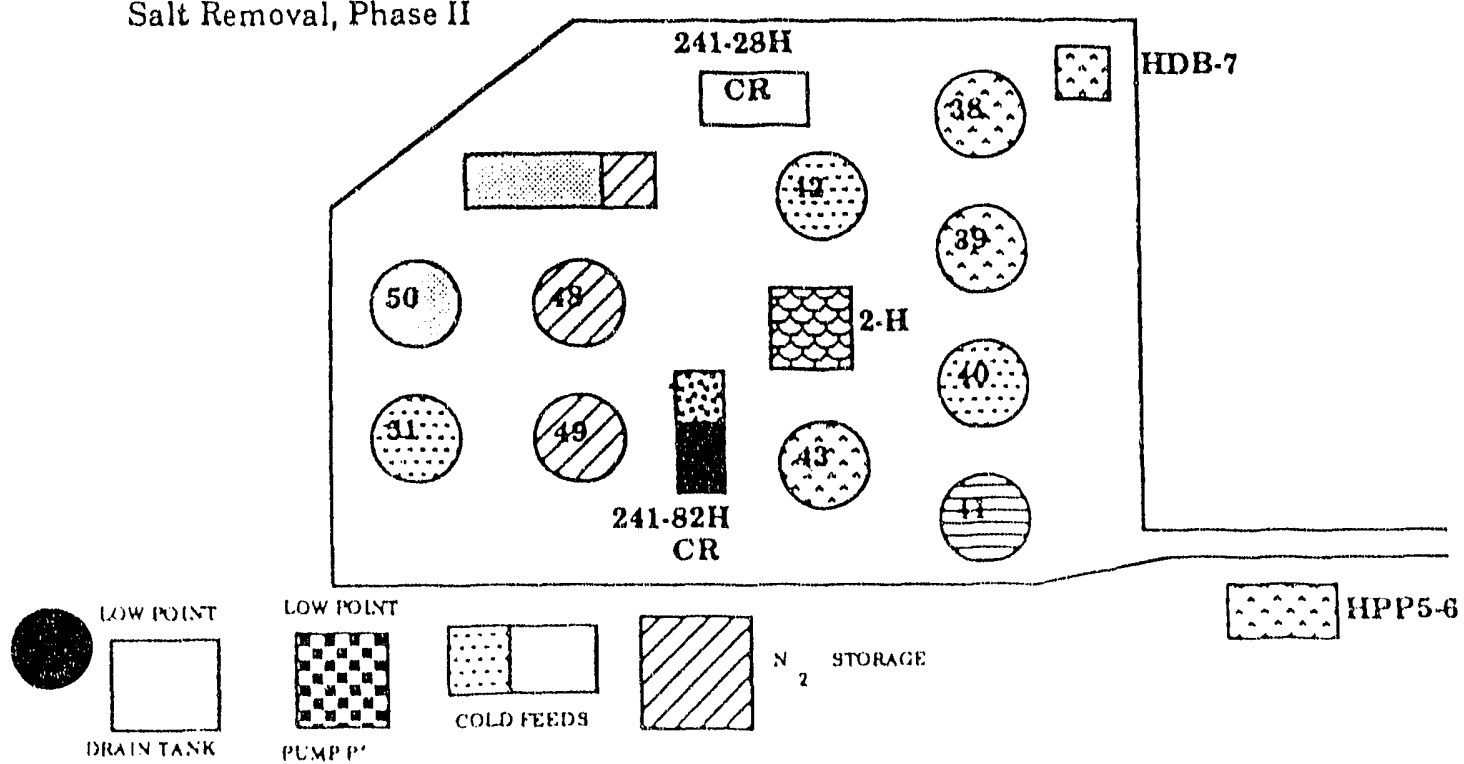

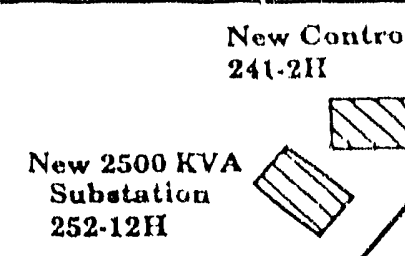
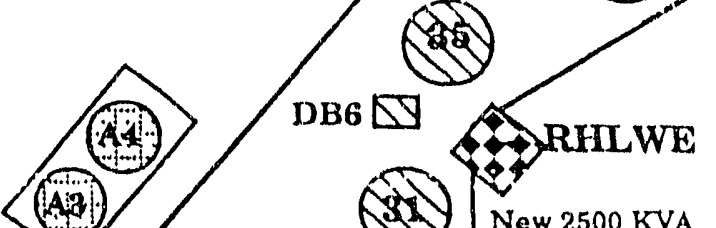

New $2500 \mathrm{KVA}$ Substation 252.16H
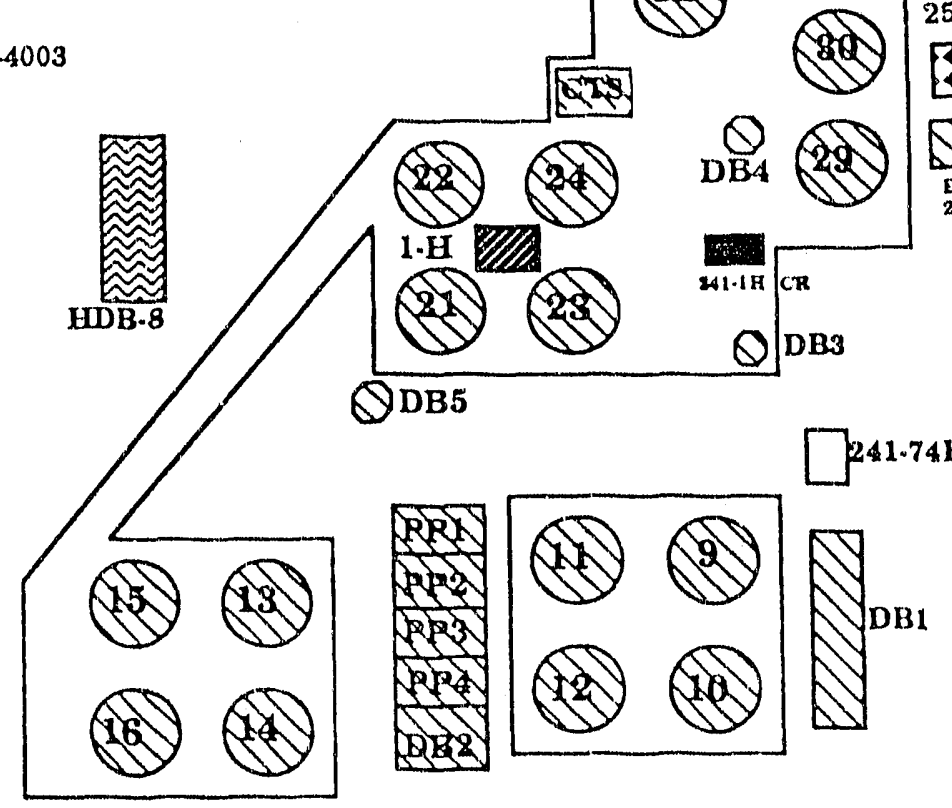

8.

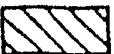

ECRICR $24.135 \mathrm{~K}$

DB5

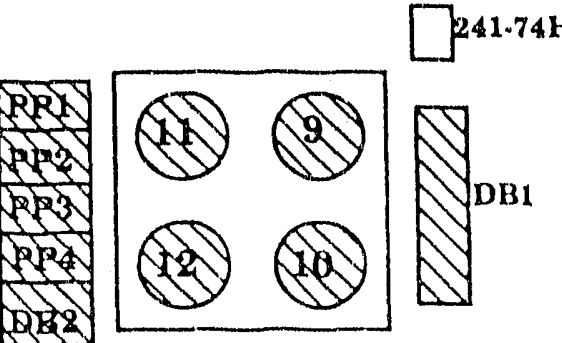

Figure III-9. H-Area 
Ihat will be transferred through HDB8 and HPP 7-10: intra-area transfers, interarea transfers, and high-heat waste transfers. These transfer lines will be jacketed pipes. Any leak in the core lines will be contained within the outer jacket and will flow into the leak detection boxes located at low points adjacent to HDB8.

\section{B. TRANSURANIC WASTE}

TRU waste is defined as waste without regard to source or form that is contaminated with alpha-emitting transuranium radionuclides with half-lives greater than 20) years and concentrations greater than $100 \mathrm{nCi} / \mathrm{g}$ at the time of assay.

\subsection{Overview}

Currently, all TRU waste $>10 \mathrm{nCi} / \mathrm{g}$ transuranics generated is being stored on TRU pads.* The TRU waste lower concentration limit was raised from $10 \mathrm{nCi} / \mathrm{g}$ to $100 \mathrm{nCi} / \mathrm{g}$ with the issuance of SR Order 5820.2 in November 1985.

TRU waste was originally buried in plastic bags and cardboard boxes in earthen trenches designated specifically for this waste. Beginning in 1965, TRU waste was segregated according to content, retrievable and nonretrievable, and additional containment was added for retrievable waste. Waste containing $\geq 0.1 \mathrm{Ci}$ per package was placed in prefabricated concrete containers and then buried. These retrievable containers were 6 feet in diameter by 6.5 feet high. Waste that did riol fit into the prefabricilted concrete containers (culverts) was encapsulated in concrete. TRU watste from the SRL. was buried in cubical concrete containers. Waste containing $<0.1 \mathrm{Ci}$ per package was buried unencapsulated in trenches designed for alpha waste.

In 1974, the storage procedures were modified to reflect new DOE criteria (DOE Manual Chapter 0511, entitled "Radioactive Waste Management") governing retrievable storage of solid TRU waste. TRU wastes contaminated to $>10 \mathrm{nCi} / \mathrm{g}$ are now stored and protected from contact with water-saturated soil in containers that can be retrieved intact and free of external contamination for at least twenty years from the time of storage. Plywood boxes placed in $3 / 8$-inch carbon steel containers, or polyethylene-lined galvanized drums, are used as primary containers. Polyethylenelined galvanized drums containing $>0.5 \mathrm{Ci}$ are additionally protected by closure in concrete culverts. In the past, containers have been stored on a concrete pad and covered with 4 feet of earth. SRS is no longer covering the filled pads with a soil overburden to reduce the waste retrieval costs.

\section{TRU Waste Management Plan}

A TRU Waste Management Plan (Figure 11l-1()) was developed to process and permanently dispose of all newly generated and existing retrievably stored TRU waste either at WIPP in southeastern New Mexico or in LLW disposal onsite.

* Containers are normally 5.5 -gallon drums, but boxes of larger size may be used to contain bulky items. 


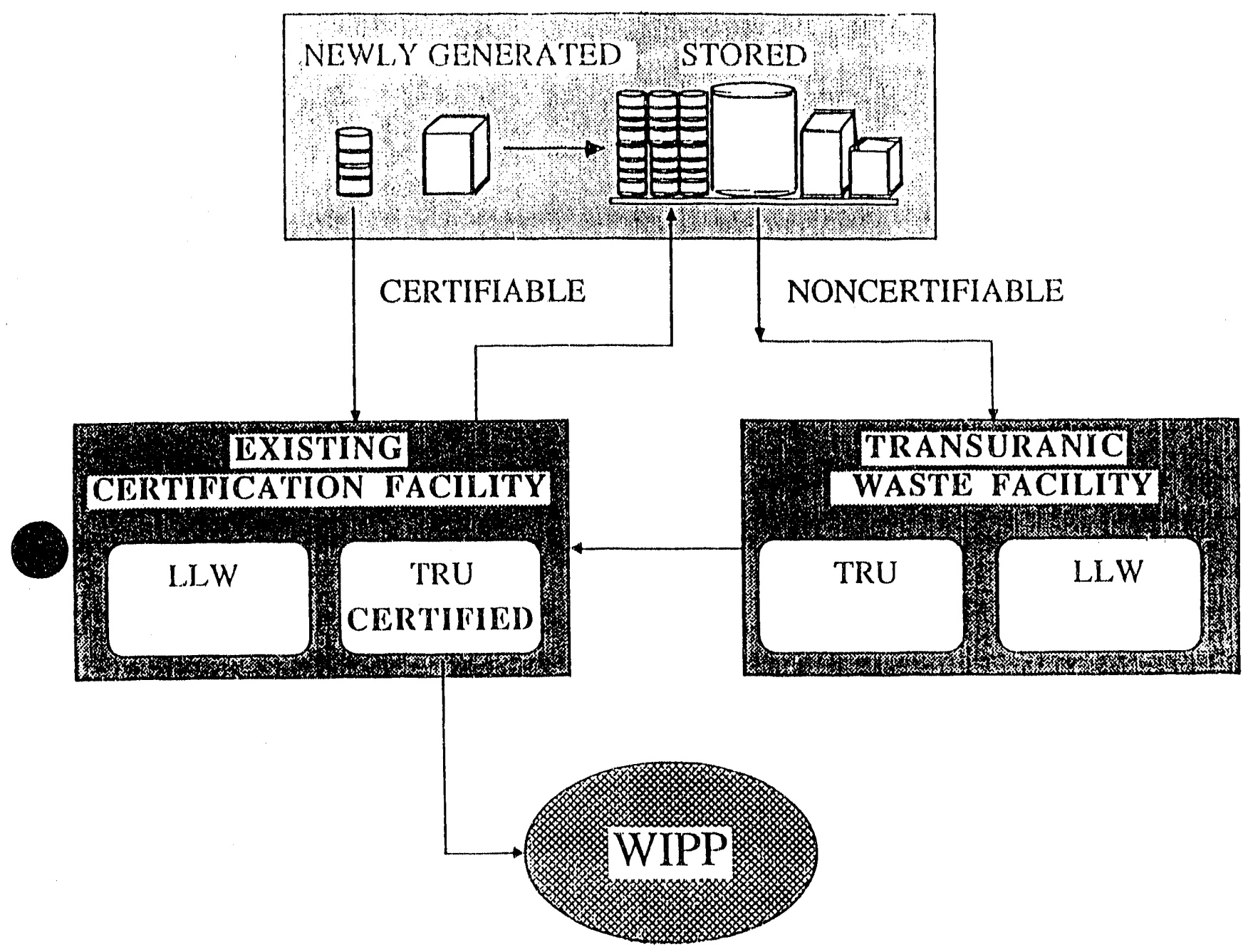

Figure III-10. SRS TRU Waste Management Plan 
The referenced plan included two new facilities: the Waste Certification Facility (WCF) and the TRU Waste Facility (TWF). The WCF will contain facilities to certify that TRU waste meets the WIPP Waste Acceptance Criteria (WAC) and to prepare it for shipment to WIPP. The planned TWF will include facilities and equipment to retrieve TRU waste from the Solid Waste Disposal Facility; to vent, purge, $x$-ray, assay, size reduce, and overpack drums; and to $x$-ray, assay, size reduce, and repackage bulky waste.

\subsection{TRU Waste Storage}

Recent changes to the TRU Waste Storage Facilities include construction of four additional TRU waste storage pads in the Solid Waste Complex, and the installation of protective structures over TRU pads storing vented waste containers. The additional storage pads were necessary due to the delayed start of the WIPP Disposal Facility. Protective structures will be added to prevent rainwater intrusion into vented TRU waste containers currently stored on the pads.

A Resource Conservation and Recovery Act (RCRA) Part B Permit Application is also being prepared for the TRU waste storage pads and the Experimental Transuranic Waste Assay Facility (ETWAF)/WCF. Practically all of the TRU waste placed on the TRU waste storage pads prior to January 199() is suspected to be co-contaminated with hazardous constituents. This mixed waste is currently being stored under EPA interim status. In accordance with SCDHEC regulations, this permit must be submitted and approved by SCDHEC prior to November 8, 1992, for continued operation of the TRU waste storage pads. Pads $1-5$ will be permitted as miscellaneous units under 40) CFR Subpart $X$, and pads 6-13 and the ETWAF/WCF will be permitted as container storage areas under 40 CFR, Support I.

\subsection{TRU Waste Treatment}

\section{Waste Certification Facility}

Beginning in April 1986, newly generated waste was received into the $30 \times 50$-foot ETWAF phase of the WCF from TRU waste generating facilities. The WCF will handle newly generated as well as retrieved waste processed in the TWF when it begins operation. Figure III-11 shows the floor plan for the second phase of the WCF.

In the ETWAF, drums are first weighed and assayed using the TRU Waste Assay System to determine whether the waste is contaminated to a level $>100 \mathrm{nCi} / \mathrm{g}$ and to determine other information required by the WIPP.WAC. This information is documented for each drum, and the records are retained. Drums that contain $<10() \mathrm{nCi} / \mathrm{g}$ are segregated and will eventually be sent to $\mathrm{LLW}$ disposal $(<10 \mathrm{nCi} / \mathrm{g})$ or greater confinement disposal $(>10$ and $<100 \mathrm{nCi} / \mathrm{g})$.

Each drum $>100 \mathrm{nCi} / \mathrm{g}$ is then $x$-rayed to verify that the contents meet the WIPP-WAC. The contents of each drum are recorded on video tape and the results of the $x$-ray are also recorded. Drums that do not meet all WIPP-WAC are either returned to the waste generator for repackaging or shipped to interim storage in the Solid Waste Complex for future processing in the TWF. WIPP-intended drums will be labeled and bar coded in compliance with WIPP-WVAC prior to shipment. These certified drums are in interim storage awaiting future shipment to WIPP. 


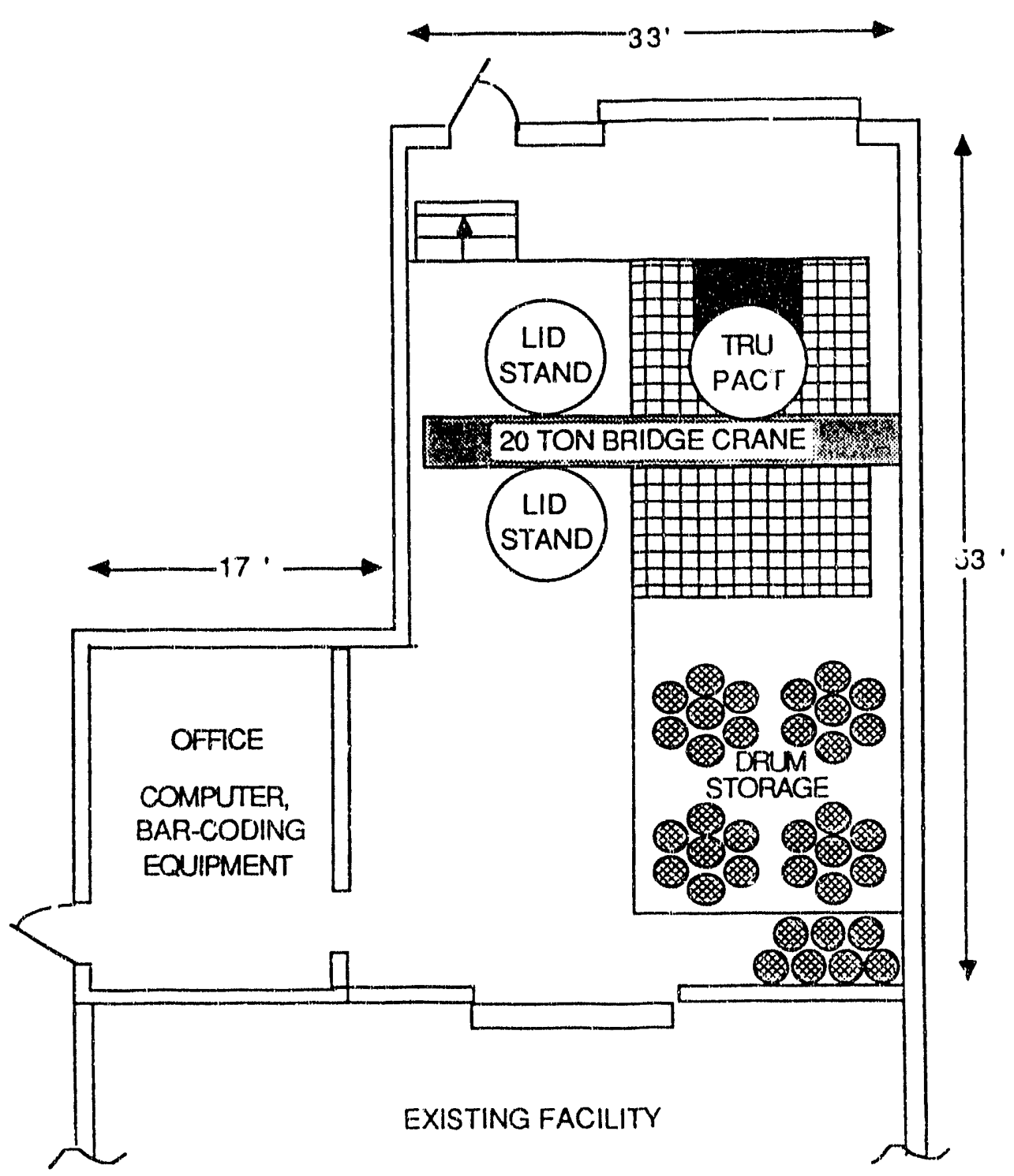

Figure III-11. Waste Certification Facility Floor Plan 
Construction of the second phase of the WCF was completed in 1988. This phase of the WCF includes facilities in which drums are barcoded, prepared for shipment, and loaded into the Transuranic Package Transporter (TRUPACT) for shipment to WIPP. Equipment to barcode, label, and band the drums into a seven-pack array will be procured prior to startup of the facility.

\subsection{TRU Waste Disposal}

All TRU wastes are currently being stored pending startup of WIPP in Carlsbad, NM. The higher activity (Pu-238) fraction of SRS waste cannot be shipped without processing to decompose or decontaminate the waste form. This is particularly true of the combustible waste, which has high hydrogen gas generation rates. However, as much as $70 \%$ of SRS TRU waste falls outside this category and can be shipped with just repackaging and/or certification per the current WIPP-WAC.

\section{Waste Disposal}

SRS will continue to package newly generated drummed TRU waste to meet the WIPP-WAC using the existing facilities. The waste which meets the WIPP-WAC and the TRUPACT-II transportation criteria will be placed into interim storage to await future shipment to WIPP. Waste that cannot be packaged to meet the WIPP.WAC, such as resins, sludges, HEPA filters, and waste too large to be packaged in a 55-gallon drum, will be placed into interim storage to be processed in the future in the TWF. Techniques to package these waste forms to meet the WIPP.WAC without processing in the TWF will also be investigated.

TRU waste shipped to WIPP will be transported in a new transport container, the TRUPACTII. The TRUPACT-II, designed for WIPP by Nuclear Packaging, Inc., has been granted a Certificate of Compliance $(\mathrm{C}$ of $\mathrm{C}$ ) from the Nuclear Regulatory Commission to transport specific payloads that have been packaged to detailed requirements as outlined in the $\mathrm{C}$ of $\mathrm{C}$ and supporting documentation. Prior to shipping waste to WIPP, SRS must revise the existing TRU waste certification program to comply with the TRUPACT $\mathrm{C}$ of $\mathrm{C}$ requirements. Revision of the program, once initiated, will require 18 to 24 months as a minimum. SRS waste that cannot be packaged to meet TRUPACT-II thermal power limits will be placed into interim storage to await processing in a future TRU waste treatment facility to be defined.

In addition to revising the waste packaging program, SRS must complete preparations for startup of the second phase of the WCF, which provides facilities to load 55-gallon drums into the TRUPACT-II. Activities to be completed include training of all personnel; purchase of barcoding, drum handling, and TRUPACT interface equipment; and preparation of operating procedures. Once preparations are complete, an Operational Readiness Review will be completed by DOE-SR, and the WIPP.WAC Certification Committee will audit the TRU waste certification program and the WCF operation. Currently, WIPP has not established a schedule for shipment of SRS TRU waste to WIPP.

The following section on Current and Future Plans provides a description of the TWF, which will prepare these wastes for shipment to WIPP beginning in 1998. Also presented are options for processing the higher activity watste fraction mentioned above. 


\subsection{CURRENT AND FUTURE PLANS}

\section{TRU Waste Facility (TWF)}

The TWF, an FY 1990 line item, was intended to be designed to retrieve and process TRU waste and prepare it for certification and permanent disposal at the WIPP.

A Title I design effort was completed in July 1990 at an estimated cost of $\$ 181 \mathrm{M}$, which represented a significant increase of the conceptual design cost of $\$ 73 \mathrm{M}$. The main reasons for this increase were compliance with $6430.1 \mathrm{~A}$ (vs. 6430.1), hazard classification change from low hazard to high hazard, and throughput increases, resulting from delays in the program due to delays in WIPP startup. Because of these reasons, the project was re-evaluated and alternative approaches were considered to better align project activities with the delays at WIPP and budgetary reductions.

A phased approach was developed, which allowed for retrieval of containers (drums, $<0.5$ $\mathrm{Ci} / \mathrm{drum}$ ) nearing their 2()-year retrievable life expectancy starting in 1994. This approach will also provide for facilities to be designed and constructed in conjunction with the testing programs at WIPP to be carried out through 1996 or 1997 . This facility will provide characterization, sorting, and segregating of $<(.5$ curies wastes for future shipment. A future Facility (FY 1996 line item) will provide for retrieval for the rest of the retrievably stored wastes $>0.5$ curies/container, perform some of the same tasks mentioned above, but in addition, provide a final waste form treatment such as vitrification and stabilization, if required, to meet future WiPP or other Federal Repository criteria. Currently, Tille I design for both parts of Phase I is about to begin.

Phase I retrieval will include the installation of a weather enclosure over the specific pad to be worked on. A telescoping excavator will remove the soil to within 6 inches of the drums. A HEAP-filtered vacuum truck will remove the remaining soil from around the containers. A specially designed lifting device, which encapsulates the drum, will be used to lift and remove the drums from the stack. The drum will then placed into an overpack, moved into a portable HEAP filtered containment facility where the drum will be punctured, using a special remote device, the head sampled for VOC concentration, purged with inert gas to change over the atmosphere in the drum, then fitted with a special carbon composite filter. The overpack will then be fitted with a lid and removed to new storage.

The second part of Phase I, a Low-Activity TRU Facility (LATF) will be constructed. The LATF will process the drums retrieved above. Drums will be received at the facility and placed into an airlock, where they will be routed to an assay system, and the radioactive isotope and concentration will be determined. This assay will determine whether or not the drum is low level or TRU waste and determine future processing. Drums which qualify as TRU waste will be $\mathrm{x}$ rayed, then moved into a processing cell where they will be opened. The contents will be segregated, characterized, sorted and repackaged for removal from the system. All waste will leave the facility through bagless transfer ports, either drums or WIPP waste boxes.

Phase II of the project will define a new line item which will provide the capability to treat the high-activity waste drums, boxes, etc. for shipment to WIPP or other repository. This treatment activity will be designed after WIPP startup and a better understanding of the requirements for the high-activity waste stream. 


\section{Alternative TRU Waste Processing Facility}

Institutional and unresolved technical issues may prevent disposal of wasteforms currently accepted in the WIPP-WAC. In addition, transportation requirements for shipping TRU waste to the WIPP in the TRUPACT-II include thermal power (decay heat) limits that are prohibitively low for solid organic waste contaminated with $\mathrm{Pu}-238$. Alternative treatment schemes are being evaluated to provide a wasteform ultimately acceptable at WIPP or as feed to the DWPF. However, this is not the current SRS TRU Waste Management Plan.

\section{LOW-LEVEL LIQUID WASTE}

\subsection{Overview}

Process waste streams may be designated as LL.W. This category includes much of the effluent cooling water from facilities involving nuclear materials or processes, spent cleaning solutions and rinse water from such facilities, purge water from storage basins for irradiated reactor fuel and target elements, surface water runoff from areas where there is a potential for contamination and distillate from the evaporation of a variety of process and/or waste streams, including the tank farm evaporators.

Until November 7,1988 , the F- and H-Area seepage basins received waste-water containing low-level radioactivity and hazardous waste from the $\mathrm{F}$ - and $\mathrm{H}$-Area separations facilities. The basins were operated in accordance with SCDHEC Interim Status Standards until November 7 , 1988. At that time, the basins were replaced by the ETF.

\subsection{LOW-LEVEL WASTE STORAGE}

The only liquid LLW nonhazardous storage facilities currently in use are those associated with the ETF described in section III.C.3.().

\subsection{LOW-LEVEL WASTE TREATMENT AND DISPOSAL}

\section{Low-Level Wastes}

Flowcharts for F-Area LLW and cooling water are shown in Figures III-12 and III-13 and flowcharts for H-Area liquid waste and cooling water are shown in Figures III-14 and III- 15. 


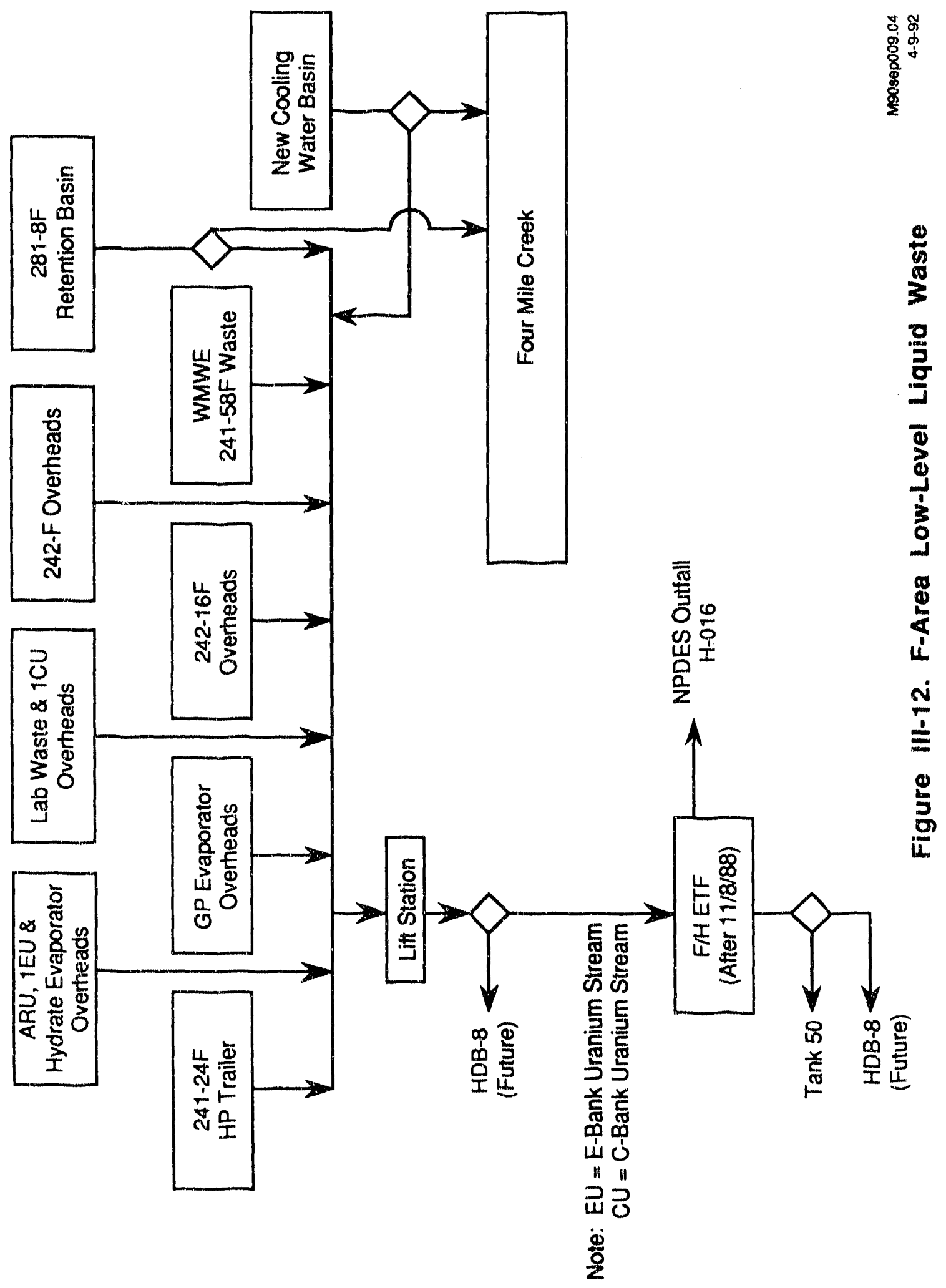




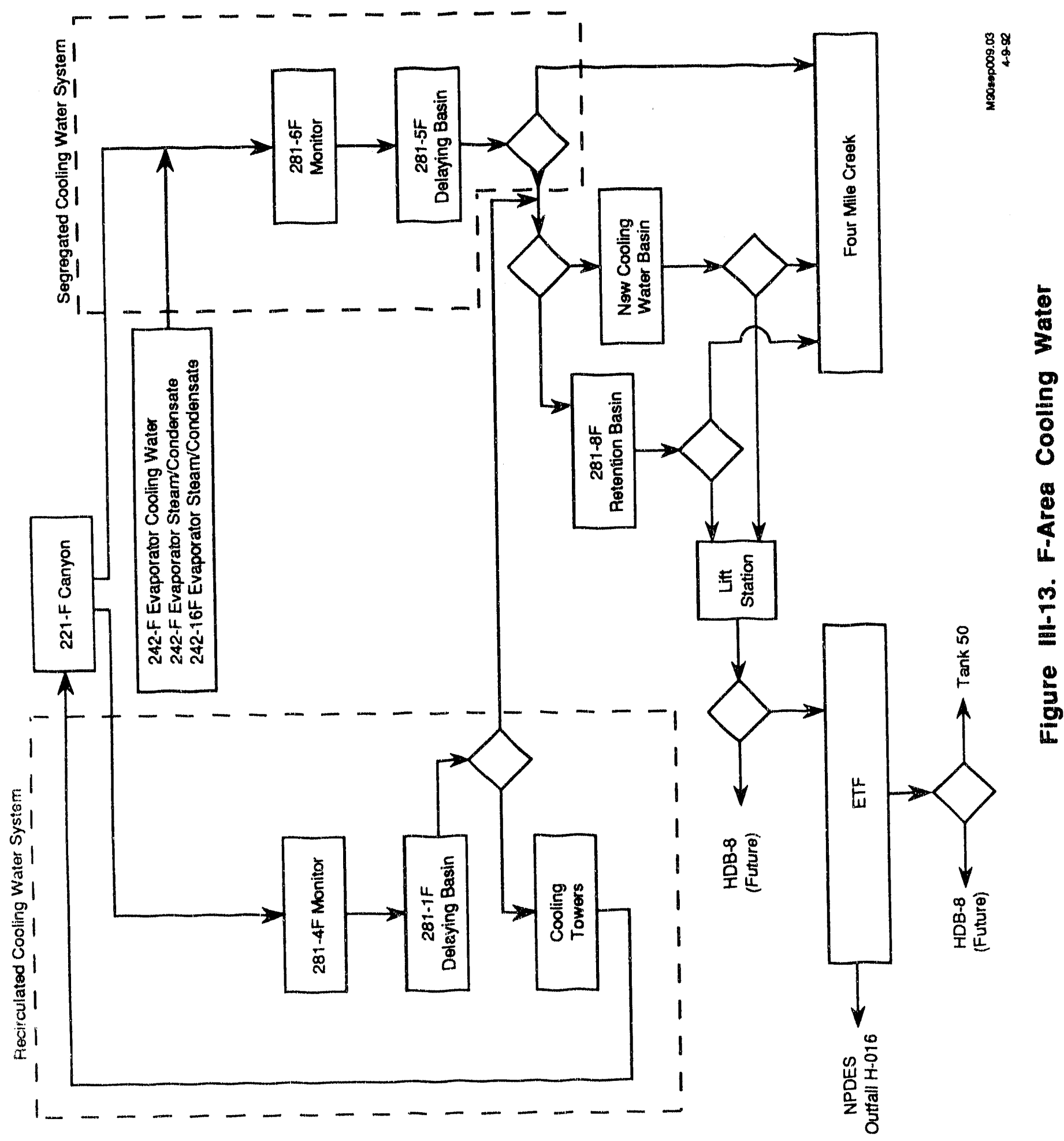


Savannah River Site

Interim Waste Management

Program Plan
III. Radioactive and Mixed Waste Management

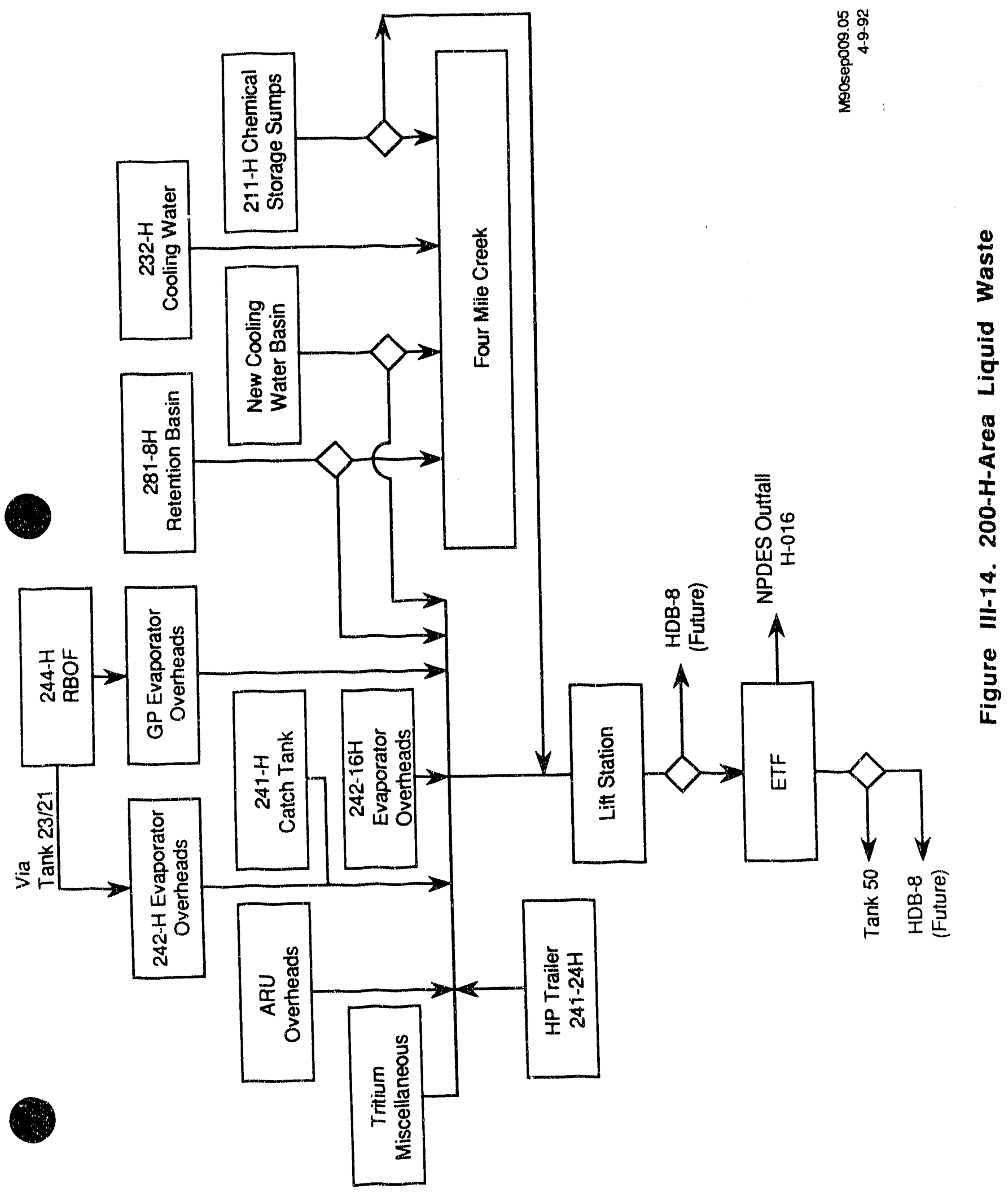




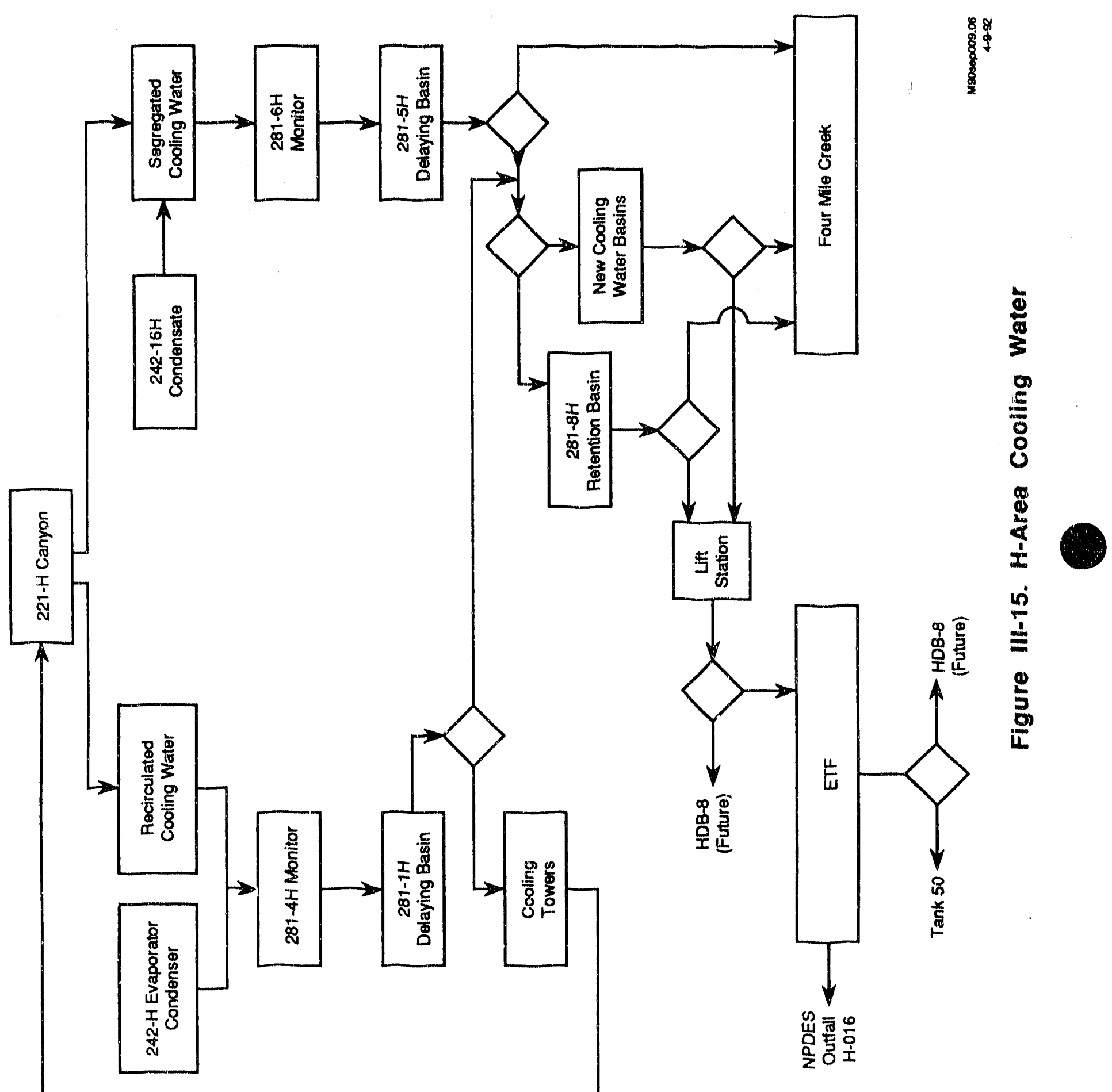




\section{F/H Effluent Treatment Facility}

The F/H ETF treats the wastewater that was previously sent to the seepage basins. The treatment process includes $\mathrm{pH}$ adjustment, filtration, organic removal, reverse osmosis, ion exchange, and evaporation.

The purpose of the $\mathrm{F} / \mathrm{H} \mathrm{ETF}$, located south of $\mathrm{H}$ Area, is to collect and treat routine process wastewater, previously discharged to the F- and H-Area seepage basins. The ETF also treats nonroutine radioactivity contaminated canyon cooling water or tank farm storm water currently discharged to the lined cooling water basins and retention basins in $\mathrm{F}$ and $\mathrm{H}$ Areas. The F/H ETF consists of a contaminated wastewater collection system and a water treatment facility as described in the following paragraphs.

\section{Wastewater Collection System}

Wastewater Collection. The F/H ETF wastewater collection system includes the following systems: 1) two new wastewater lift stations, one in each area; 2) four new diverted cooling water basins, two in each area; 3 ) two existing retention basins, one in each area; 4) two 450,000-gallon wastewater collection tanks located at F/H ETF; and 5) various gravity sewer lines and force mains.

Wastewater Lift Stations. The F- and H-Area lift stations collect wastewater from the chemical separations and interim waste management facilities (200 Areas) and can transfer these streams to F/H ETF or future HDB-8 (H-Area diversion box 8).

The lift stations routinely receive low-level aqueous wastewater from Separations and Interim Waste Management waste evaporation systems. On a nonroutine basis, they may receive diverted cooling water from the new cooling water basins and/or the existing retention basin and diverted storm water from the existing retention basins. Each lift station has a 75,000-gallon lift station tank that is contained in a 181,000-gallon concrete cell. Wastewater collected in these tanks is automatically pumped to F/H ETF 450,000-gallon wastewater collection tanks by one of two 50()gpm pumps.

Diverted Cooling Water Collection Basins. New cooling water basin systems were constructed in $\mathrm{F}$ and $\mathrm{H}$ Areas to provide an additional 2.0-million-gallon capacity to segregate and contain diverted cooling water from the canyon facilities. Each new basin system consists of an ().5()-million-gallon "hot" basin and 1.5-million-gallon "moderate" basin. Routinely, the first 0.5 million gallons of a cooling water diversion will be collected in the "hot" basin, and the next 1.5 million gallons would flow into the "moderate" basin. If the diversion is $>2.0$ million, the remainder would flow into the existing retention basin, which may provide up to an additional 6.0-milliongallon capacity. Historically, approximately $90 \%$ of the activity in a cooling diversion is contained in the first 0.5 million gallons. The new cooling water basin system, in conjunction with the existing relention basin, will provide segregation as well as additional containment.

Diverted water collected in any basin, that is, the "hot" basin, the "moderate" basin, or the existing retention basin can be disposed of by sending it to: 1) F/H ETF for treatment, 2) the tank farm via HDB-8 (future), or 3) NPDES outfalls to Four Mile Creek. The disposal path is determined by established radioactivity guidelines. 


\section{Treatment Facility}

Routine process wastewater effluents and nonroutine discharges of moderately contaminated cooling water or storm water are processed through a treatment facility to reduce contaminants to levels acceptable for discharge to surface streams. Several potential processes were investigated to determine the best available treatment technology; a combination of filtration, organic removal, reverse osmosis, and ion exchange was determined to comprise the treatment system. Laboratory and pilot-scale testing were used to determine this optimurn scheme for treating F- and H-Area effluents.

Treated effluents are discharged to Upper Three Runs Creek if within applicable discharge limits; an NPDES permit has been issued by SCDHEC.

The volume of waste generated by the treatment facility is minimized by concentrating by evaporation and sending the concentrate to the H-Area waste tank farm for eventual disposal by saltstone. Solid waste is placed in the radioactive Solid Waste Disposal Facility onsite or is stored for future treatment and disposal as a mixed waste.

\section{Interim Contaminated Cooling Water Control}

Facilities have been installed to better control contaminated water. These interim contaminated water control (ICWC) facilities include:

- Design for temporary transfer lines to return contaminated water from the F- and H-Area retention basins to the tank farms, allowing time for rapid material purchase and installation in the event of a major radioactivity release. The design for these lines is complete. The F/H ETF project includes physical installation of a jacketed line to HDB-8, which will serve the same functions as these lines.

- Covers for the H-Area canyon cooling water delaying basins. These covers will reduce the potential for airborne contamination and keep wildlife out of the basins.

\section{Storm Water Monitors}

Storm water is monitored for six water shed areas in $\mathrm{H}$ Area and three in F Area. Diversion gates are used to automatically direct water to the area outfall or, if contaminated, to retention basins. Originally, the monitors were set up to initiate diversion if radiation rates exceed twice the normal background. To improve sensitivity, all of the monitors have been modified. The detector location was flooded by construction of a weir so that the detector is totally immersed. The monitor is seven times more sensitive to storm water radioactivity because no shielding is required between the detector and the storm water. These monitors are calibrated to divert to the H-Area retention basin whenever storm water activity exceeds the site's $10 \mathrm{~d} / \mathrm{m} / \mathrm{mL}$ release standard. 


\subsection{Organic Solvent Waste}

The two Separations facilities in $\mathrm{H}$ and $\mathrm{F}$ Areas periodically generate quantities of radioactively contaminated organic solvent waste. This waste primarily contains degraded organic solvents such as tributylphosphate (TBP), ultrasene, and n-paraffin.

\section{Organic Solvent Waste Storage}

There were originally 32 underground storage tanks established at the SWDF with the purpose of storing spent solvent wastes from the Separations areas. Tanks S1 through S22 were the first solvent storage tanks that were used to store spent organic solvent and were eventually used to facilitate the burning pit incineration of much of the received solvent waste. These tanks are currently empty and have been removed from active service since 1982.

Tanks S23 through S28 were installed and turned over to Waste Management in 1976 for operational use, and Tanks S29 through S32 were turned over in 1981. Tank S31 was never used for underground storage and has subsequently been excavated, while Tank S32 was used to store tritiated oil and was decommissioned in 1988.

Solvent storage Tanks $S 23$ through $S 30$ are currently in active service. The tanks are constructed of 3/8-inch carbon steel and coated with three applications of bitumastic paint to prevent external corrosion. Additional protection is provided to Tanks S29 and S30 by means of a 30-mil PVC liner that extends below the tank concrete pad up to the ground surface. Each underground solvent tank is cylindrical with a 25,000 -gallon storage capacity (10-foot 6-inch diameter x 38-foot 10-inch length). All solvent tanks are anchored to a concrete pad about 15 feet below grade that slopes 0.2 inch per foot to a 60 -gallon steel collection sump. limits:

All waste solvents stored in the solvent storage tanks must meet the following normal operating

$$
\text { Limit }
$$

$\mathrm{pH}$

Alpha activity

$>4$ and $<11$

Beta-gamma activity

$<5 \times 10^{4} \mathrm{~d} / \mathrm{m} / \mathrm{mL}(<16 \mathrm{~d} / \mathrm{m} / \mathrm{mL}, \mathrm{U}-235)$

Tritium activity

U-235

$<2 \times 10^{7} \mathrm{~d} / \mathrm{m} / \mathrm{mL}$

$\leq 0.050 \mu \mathrm{Ci} / \mathrm{mL}$ (overall tank concentration)

$16 \mathrm{~d} / \mathrm{m} / \mathrm{mL}$

Before a generator loads any liquid solvent waste into the solvent trailer for transport to the tanks, operating personnel must verify that analyses for radionuclide activities and $\mathrm{pH}$ have been performed, and the solvent analysis is within the limits listed in the above table. Also if the solvent waste originated in a process where U-235 contamination was possible, the laboratory analysis must definitively show the content of this isotope. If the liquids originated in a process where U-235 contamination was possible, the laboratory analysis must also show the content of this isotope. 
All of the sumps for the active solvent tanks are routinely checked to verify tank integrity. Currently, the Waste Management Operations surveillance schedule requires checking the solvent tank sumps on a biweekly basis.

\section{LOW-LEVEL SOLID WASTE}

\subsection{Overview}

Solid waste materials that have become contaminated with beta-gamma and/or low levels of alpha radioactivity are defined as LLW. Waste contaminated with beta-gamma emitters is separated into low level and intermediate level for burial. Solid LLW is defined as waste that radiates $<200$ mrads/hr or $200 \mathrm{mR} / \mathrm{hr}$ at 3 inches from an unshielded container and contains $<10 \mathrm{nCi} / \mathrm{g}$ of TRU contaminants. Waste with low radiation rates and tritium contaminants that have the potential for offgassing is buried as intermediate-activity waste. Intermediate-level waste radiates $>200 \mathrm{mrad} / \mathrm{hr}$ or $200 \mathrm{mR} / \mathrm{hr}$ at 3 inches. LLW is generated by Analytical Laboratories, Reactor Materials, Reactors, Separations, Site Services, SRL, Tritium, and Waste Management. The following materials are examples of solid LLW that are routinely handled:

- Operating and laboratory waste: small equipment, protective clothing, analytical waste, decontamination residue, plastic sheeting, and gloves.

- Contaminated equipment: obsolete or failed tanks, pipe, jumpers, and naval hardware.

- Reactor and reactor fuel hardware: irradiated fuel components and housings not containing fuel.

- Spent lithium-aluminum targets: the irradiated Li-Al alloy from which tritium has been extracted.

- Spent deionizer resin from reactor areas.

A general review flowchart for the radioactive solid waste is shown in Figure III-16.

Estimated volumes and curies of radioactive waste (transuranic, low-level, and intermediatelevel) in the Solid Waste Disposal Facility are listed in Table III-5. The SWDF low-level solid waste volume is shown in Table III-6.

\subsection{Low-Level Solid Waste Treatment}

There is one waste management facility that treats solid radioactive waste: the $\mathrm{H}$-Area compactor (Building 253-H). Another facility, the Landfill Monitoring Facility, is not being operated due to technical considerations and lack of manpower. In addition, a proposed facility for treating low-level solid waste is the Consolidated Incineration Facility. 


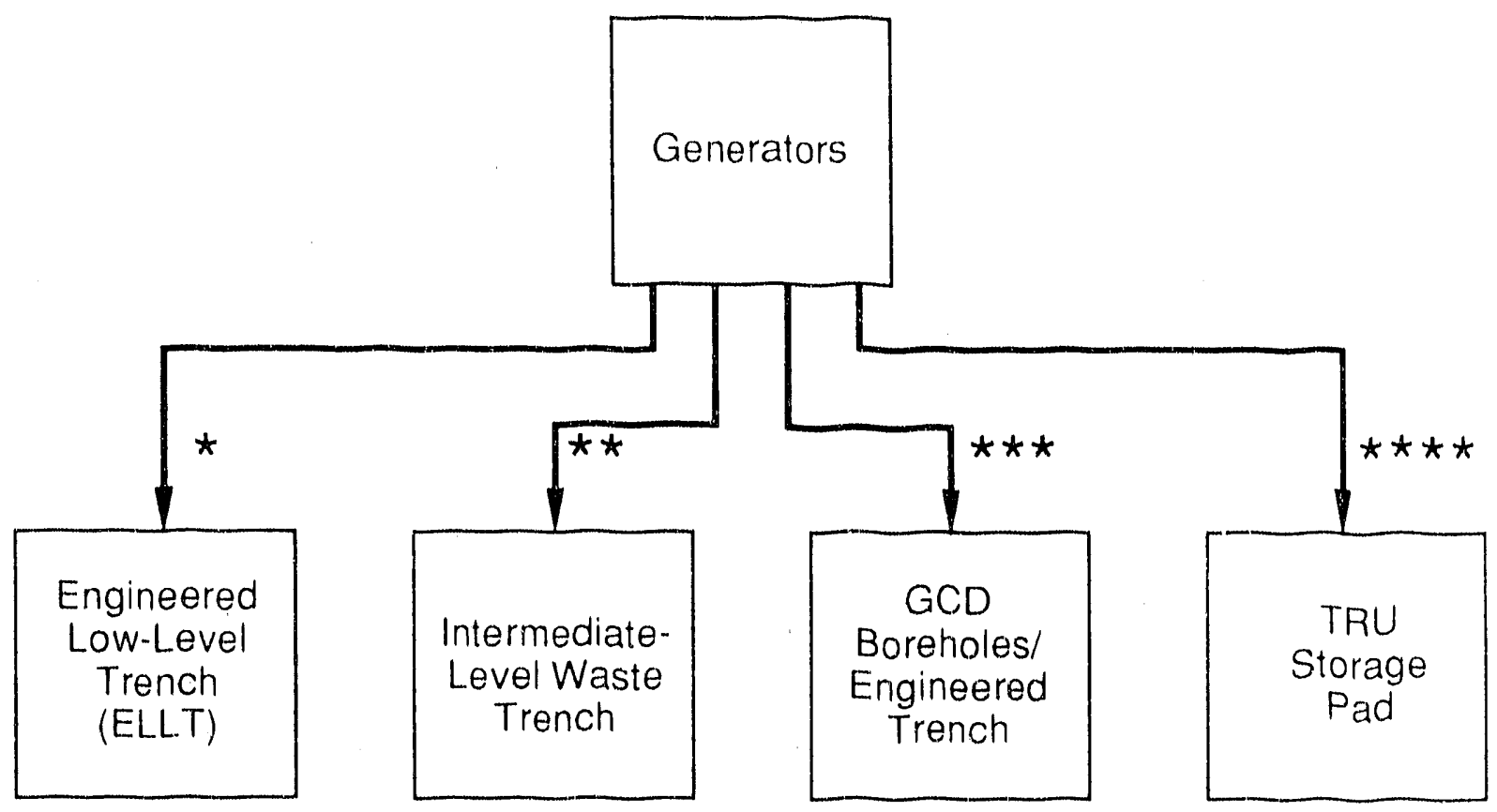

" Low-Level Waste: At 3" = <200 mR/hr, <200 mRad/hr, $<200 \mathrm{mRem} / \mathrm{hr}$ and contains $<100 \mathrm{nCi}$ TRU/g.

** Intermediate-Level Waste: At 3" >200 mR/hr, >200 mRad/hr, or >200 mRem/hr and contains $<100 \mathrm{nCi}$ TRU/g.

*** The higher activity fraction of intermediate-level waste is emplaced in Greater Confinement Disposal (GCD) boreholes or the GCD engineered trench.

**** TRU Waste $=>100 \mathrm{nCi}$ TRU/g.

Figure III-16. Solid Radioactive Waste Flowchart 
Table III-5. Solid Waste Inventory (12/31/91)

Isotope

Co

Cs

Fiss. Prod.

Ind. Act.

Other

$\mathrm{Sr}$

DePu

ENU

$\mathrm{Pu} 241$

$\mathrm{Pu} 242$

Am 241

Am 243

$\mathrm{Cm}$

Cf

$\mathrm{Pu} 239$

U 233

N Uran

Np 237

Pu 238

Deuterium

Tritium

Th
Isotopic Quantity Received

Volume, ft 3

$$
1990
$$

4,232

1,822

606,450

46,014

16,107

1,112

20,511

35,112

3

0

150

0

58

2,548

149,934

90

1,202

94

39,415

48,122

630
1991

$$
\begin{array}{r}
4,353 \\
36
\end{array}
$$

631,063

18,752

12,880

10,289

12,033

0

0

114

0

0

3,258

81,155

0

16,632

33,191

31,948

63
Cumulative

203,021

116,449

$13,721,173$

$1,409,075$

179,338

4,482

667,798

827,070

3,332

1,310

5,694

137

275,002

65,181

$2,293,683$

12,850

948,688

46,277

905,531

4,775

$1,090,706$

46,817

Total

973,606

855,771

$22,828,42.5$

Table III-6. Solid Waste Disposal Facility (643-E, 643-7E, 643-28E)

Low-Level Solid Waste, $\mathrm{m}^{3}$ (inventory as of 12/31/91)

Type of Waste

Low Level

Low activity

Intermediate

Total

Volumetric Generation, $\mathrm{ft}^{3}$

1990

$\begin{array}{rr}862,604 & 751,563 \\ 14,533 & 12,169\end{array}$

$\begin{array}{rr}862,604 & 751,563 \\ 14,533 & 12,169\end{array}$

$\approx 20,000,000$

Transuranic

Retrievable

Nonretrievable
$27,180 \quad 14,147$

160,100

Total
460,412 


\section{Low-Level Waste Compaction}

Low-level radioactive waste volumes are being reduced by compaction processes in $\mathrm{H}$ Area (Building 253-H) and $\mathrm{M}$ Area. The 253-H container compactor is achieving volume reductions of 8 to $10: 1$, while the M-Area compactor is achieving a 5:1 compaction ratio. These compactors compact waste types typically placed in cardboard waste boxes and plastic bags. The Building 253-H compactor processes beta-gamma waste from the 200 Areas (Separations, Waste Management, and Tritium) and from SRL (Building 773-A) with radiation rates of $50 \mathrm{mrad} / \mathrm{hr}$ or less. The M-Area compactor processes primarily uranium-contaminated waste from M-Area facilities.

Current programs to increase compaction efforts include compaction of tritium-contaminated waste at Building 253- $\mathrm{H}$ and increasing utility of compactors by educating generators.

\section{Landfill Monitoring Program}

Waste Management has established the Landfill Monitoring Program to monitor clean waste from regulated areas to verify that it can be sent to the sanitary landfill rather than the radioactive waste Solid Waste Disposal Facility. Boxes containing $<10 \mathrm{nCi}(0.00000001 \mathrm{Ci})$ per box are sent to the landfill. Those boxes containing $>10 \mathrm{nCi}$ per box are sent to the compactor prior to disposal in the Solid Waste Disposal Facility. The program began as a pilot operation in February 1987. The Landfill Monitoring Facility was turned over for operation in November 1987. The program was halted in 1991 due to technical considerations and lack of manpower.

\subsection{Low-Level Solid Waste Disposal}

\section{Solid Waste Disposal Facility (SWDF)}

One centrally located site (Figure III-17) is used to store or dispose of all radioactive solid waste produced at SRS, as well as DOE shipments from offsite. This site occupies 195 acres between the $\mathrm{F}$ and $\mathrm{H}$ separations areas, approximately 6 miles from the nearest plant boundary. The original area of 76 acres (643-E), which began to receive waste in 1953, was filled in 1972, and operations were shifted to a 119-acre site contiguous to the original area (643-7E). In 1986, a portion of the 119-acre site was closed and designated 643-28E when it was determined to contain potentially hazardous waste. A closure plan was submitted to and approved by SCDHEC. Truck access to the disposal or storage facilities is provided by a paved road and many unpaved roads inside the fenced area. Railroad spurs permit shipments of large pieces of contaminated process equipment from the operating areas.

The relatively level land and the specially selected Bahia grass cover effectively control surface erosion at the storage and disposal site. Surface drainage ditches channel the runoff of rainwater (47 inches each year) to provide further erosion control. Soils underlying , he storage site consist of nearly a thousand feet of mostly unconsolidated sands, clayey sands, sandy clays, and clays. The principal surface and near-surface soils are clayey sands averaging about one-third clay. These soils have a high ion exchange or other retention capacity for most elements, including plutonium, cesium, and strontium. Tritium mobility is not affected by the soils. The cross section of the soil underneath the burial ground is given in Figures III-18 and III-19. 

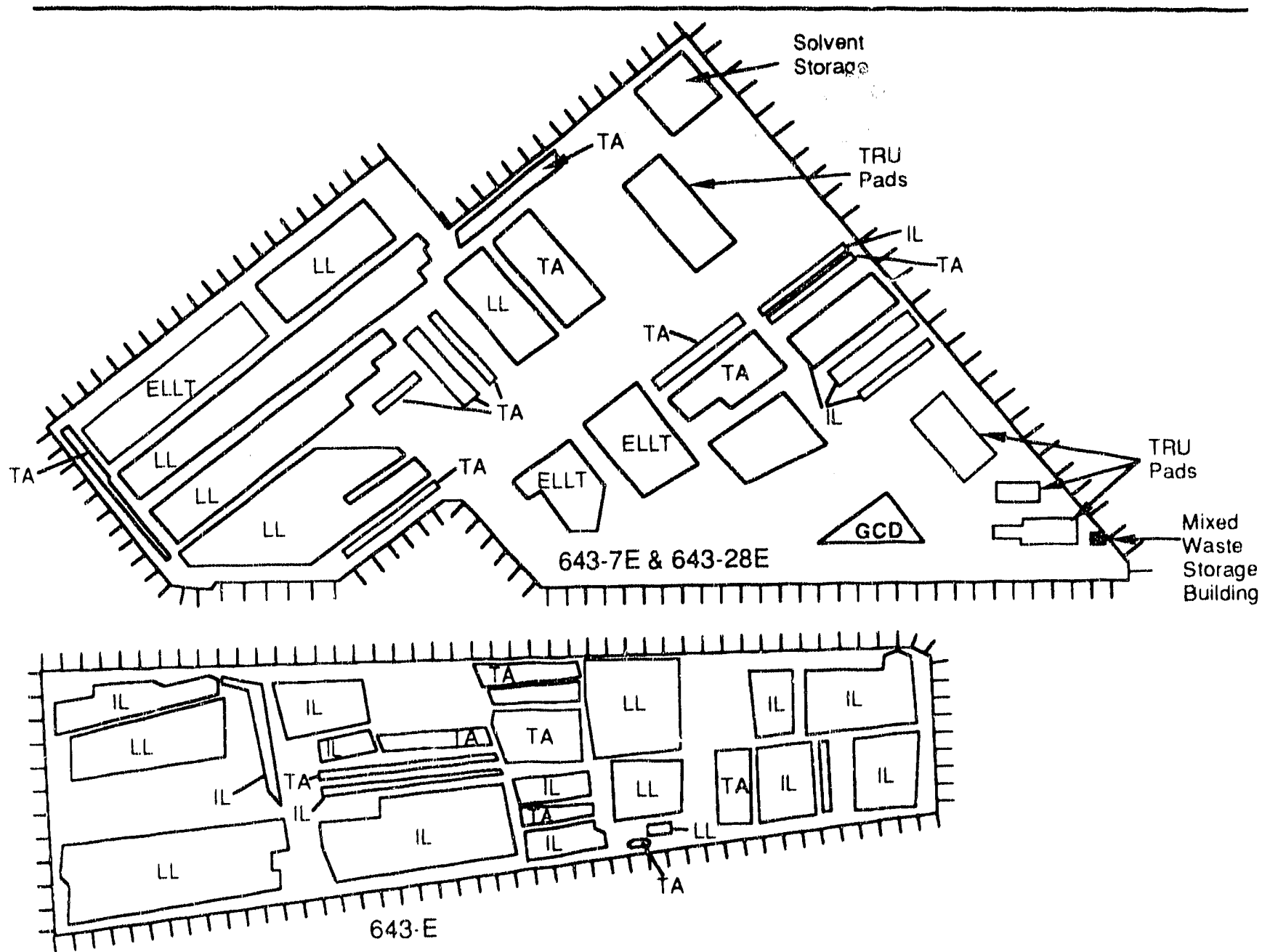

LL - Low-Level Beta-Gammia Waste

IL. - Intermediate-Level Beta-Gamma Waste

TA - Trench Alpha Waste

GCD - Greater Confinement Disposal

ELLT - Engineered Low-Level Trench

Figure III-17. SWDF Showing Zones of Trench Alpha, Intermediate-, and Low- Level Beta-Gamma Waste, and Solvent Storage 


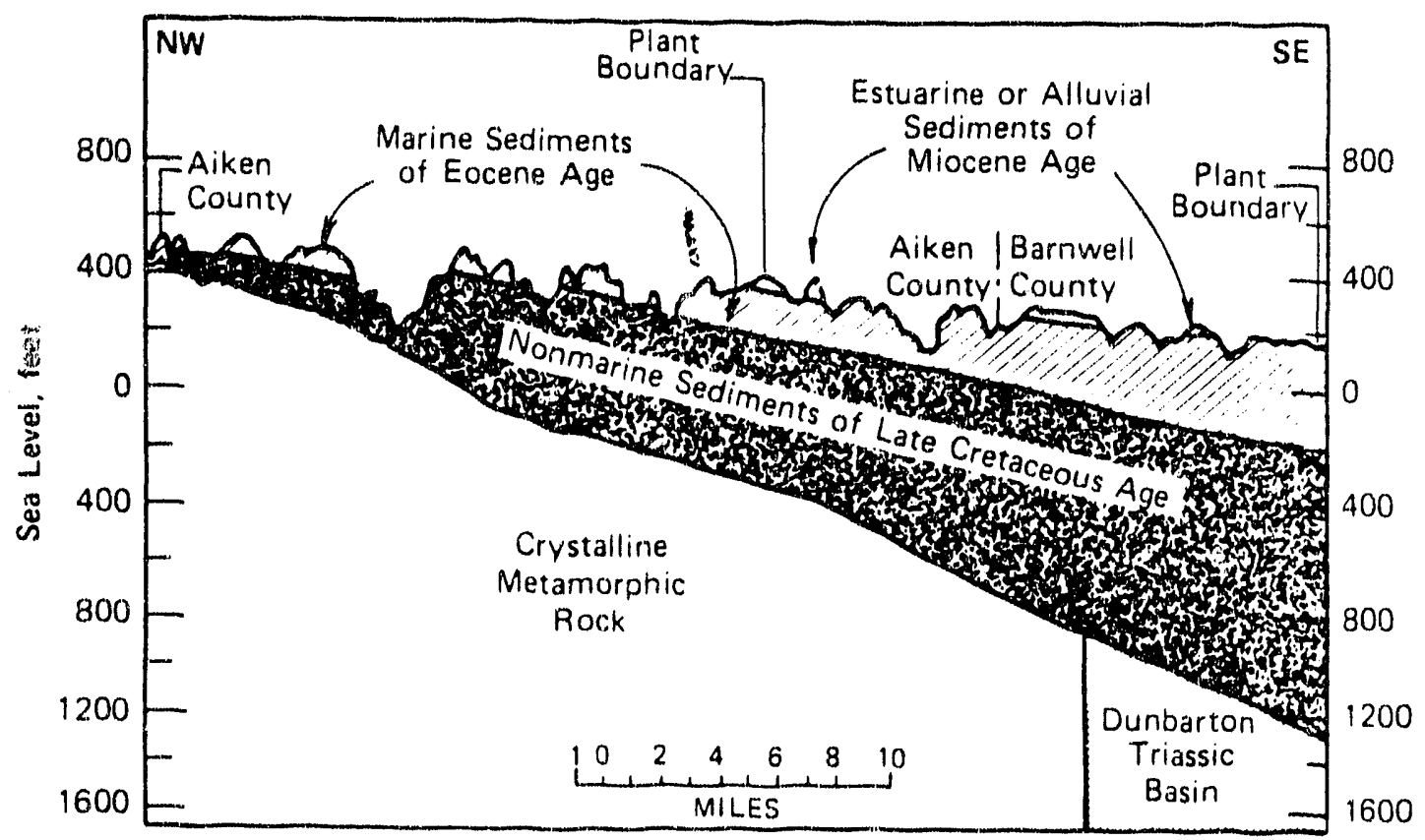

Figure III-18. Profile of Geologic Formation Beneath the Savannah River Plant 


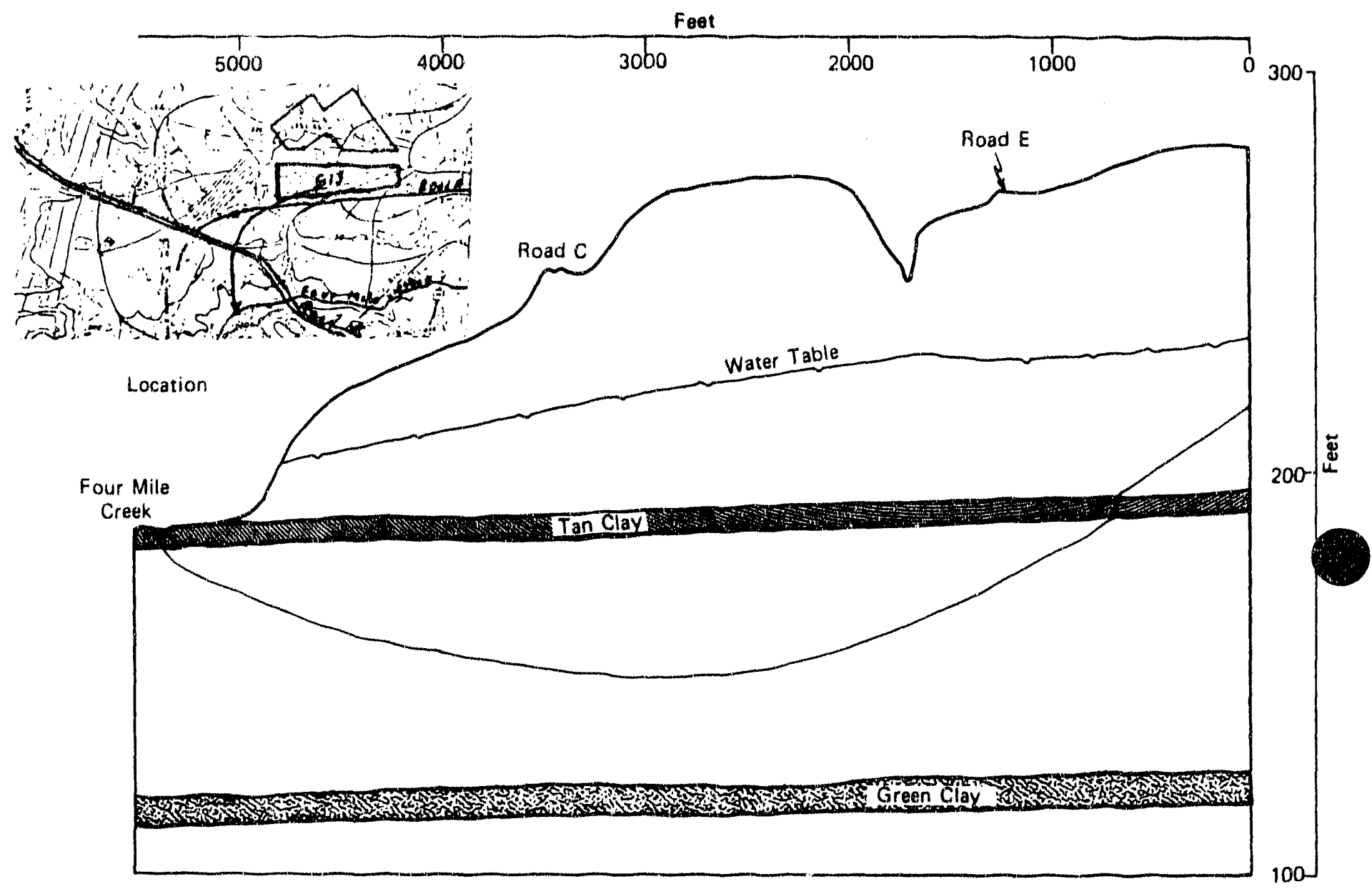

Figure III-19. McBean Flow Path Cross Section 
The mean water table is at a depth of about 45 feet. During a normal year, the fluctuation across the mean level is about 2 feet; the extreme variation noted was in 1960 when the water table rose about 7 feet above the normal mean.

In addition to the solid radioactive wastes deposited there, SWDF 643-7E has provided interim storage for radioactive degraded organic solvents (tributylphosphate in kerosene or n-paraffin) in eight separate 24,600-gallon underground storage tanks (S23-S30). Before these 8 tanks were put into use, 22 tanks in 643-E were used for solvent storage. Tanks S1-S22 are essentially empty except for the sludge and liquid heels in some of them.

Within the SWDF, the primary disposal mode for solid radioactive waste is burial in earthen trenches. Criteria for selection of trench sites include:

- Groundwater table at least 10 feet below the bottom of prospective trenches

- Absence of perched groundwater tables that would cause leaching of buried waste.

- Soil containing enough clay to maintain the integrity of the excavation walls without support.

- Topography conducive to level trenching and controlled surface water runoff.

LLW is disposed of in engineered low-level trenches, and intermediate-level waste is disposed of in slit trenches or the greater confinement disposal vault or boreholes.

\section{Rigid Containers for Solid Radioactive Waste}

Cardboard and fiberboard boxes are no longer used as final disposal containers for packaging solid radioactive waste for shallow land burial. Rigid metal containers (B-25 metal boxes) are now used in most cases to obtain greater trench utilization through container stacking. B-25 metal boxes have been used since mid-1984.

The following containers are used for waste burial:

- 55-gallon drums,

- 90-cubic foot metal boxes (B-25s) and 45-cubic foot metal boxes (B-12s), and

- Engineered steel boxes designed by the Project Department and approved by WMO and WMT.

Waste generators currently use rigid containers for all waste except building debris, soil, and other bulky material that does not fit in standard containers. These wastes are still shipped to the burial ground in a noncontainerized form. 


\section{Engineered Low-Level Trench}

Low-activity beta-gamma and low-activity alpha wastes $(<10 \mathrm{nCi} / \mathrm{g})$ packaged in 90 -cubic foot metal boxes are currently being disposed of in engineered low-level trenches (ELLT), essentially large open witit in which wasteboxes are stacked. The first ELLT was placed in operation in April 1985. To dot tiree ELLTs have been filled, with the fourth ELLT (ELLT-4) currently receiving waste. ELL.T-4/was placed in service in July 1987. (Some space was reserved in ELLT-2 for burial of large equipment.) ELLT-3 contained space for about 26,500 B-25 boxes.

A typical ELLT is about 22 feet deep, with the other dimensions adjusted to maximize the available space. The walls of the trench are sloped to prevent cave-ins, and a ramp allows access by waste shipment trucks. Waste boxes are offloaded and stacked by an extendable-boom forklift.

The trench floor is sloped slightly to one side and end, so that rainwater will run into a sump located at the low corner of the trench. The sump is used to eliminate the potential for standing water while the trench is being filled ( 1 to 2 years). Rainwater is monitored to confirm that no contamination exists before it is released to surface drainage. If contamination is detected, the liquid will be disposed of via the plant liquid waste handling system.

Since the wasteboxes are now stacked instead of dumped as in conventional trenches, the ELLT has much more efficient space utilization. Since there is no need for the 10 feet of soil between conventional trenches, the amount of land available for waste disposal has been increased as well. The space between the sloped walls and the stacked wasteboxes may be used for disposal of 55-gallon drums, bulky containerized waste, and contaminated soil.

\section{Slit Trenches}

Trenches for storing intermediate level and bulky noncontainerized low level (alpha and betagamma) and containerized offsite wastes, are excavated 6 meters wide, 6 meters deep, and up to 300 meters long and are called slit trenches. Wasteforms emplaced in the slit trenches are covered with soil shortly after emplacement to maintain radiation control and to reduce the potential for spread of contamination. Ultimately, all trenches filled with waste are backfilled with a minimum of 1.2 meters of soil to reduce surface radiation rates to less than $5 \mathrm{mrem} / \mathrm{hr}$, to reduce the potential for spread of contamination, and to minimize plant and animal intrusion into the waste.

Most wasteforms generated offsite are buried in slit trenches or stacked in ELLT-4, as required to optimize burial space. Some U.S. Navy submarine reactor components are stored above grade and covered with soil.

A method for improving the disposal method for intermediate-level waste was developed using demonstration projects. The demonstrations, entitled greater confinement disposal (GCD), provide a method for encapsulating the waste in concrete/grout and monitoring the solidified wasteforms for water leaching of any radionuclides. 


\section{Greater Confinement Disposal Vault and Boreholes}

The objective of GCD is to provide a near-zero release facility that will require minimum maintenance after closure for disposal of the higher activity fraction of the low-level solid betagamma waste and low-level alpha waste. The methods used to meet this objective are deeper burial to prevent root and animal intrusion and stabilized wasteforms.

Twenty 9-foot-diameter boreholes have been augered to a depth of about 30 feet. Nineteen boreholes contain a 20 -foot long, 7-foot-diameter fiberglass liner with a fiberglass bottom, while the remaining borehole contains a 20 -foot-long, 7-foot-diameter steel liner. A steel collar lines the top 10 feet of each borehole to prevent soil from sluffing off into the borehole. The fiberglass liners, which can hold up to forty-two 55-gallon drums of waste, are grouted in place. Essentially all of the boreholes have been filled with waste.

All waste emplaced will be stabilized by placing grout around the wasteforms to fill void spaces. A one to two-foot-thick concrete cap will be poured in the top two feet of the liner. As each borehole is filled, the steel collar will be removed and the borehole will be backfilled above the waste monolith. After all of the boreholes are filled, the earth cover will be removed, and a clay cap will be formed over the boreholes. Native clay will be added on top of the cap per a site closure plan that provides a design, which will prevent root and animal intrusion and discourage future human intrusion. Monitoring wells (dry wells) are placed in each borehole and around the perimeter of the GCD site. Monitoring and modeling of the operation will proceed with waste emplacement.

A second method of GCD emplacement is the GCD-engineered trench (GCD-ET). This trench was constructed for the disposal of reactor scrap metal, spent melt crucibles, and the more bulky wasteforms. Success of this trench will depend on how the waste is packaged. Reinforced concrete forms the walls of the four-celled, 100-foot-long, 5()-foot-wide disposal trench. To minimize rainwater intrusion, steel covers are placed over each disposal cell when it is not in use. Also, drainage is provided to channel water away from the trench. A leachate collection system was installed below the floor of the trench to monitor the performance of the disposal cells. The first waste was placed in the GCD-ET in April 1987.

\section{Disposal Limits}

Table III-7 shows the annual disposal limits for beta-gamma emitting radionuclides in the burial ground.

The limits are based on maintaining SWDF inventories at or below those used for documenting the Safety Analysis of Burial Ground Operations (DPSTA-200-10, Supp-8). Present information on migration rates indicates that the maximum inventory will not cause an unacceptable dose to man at boundaries of the SWDF after cessation of plant operations and institutional control. SRL has completed a study which indicates that vegetative uptake represents, by far, the most likely scenario for radionuclide transfer to man and recommends additional backfill and a lowpermeability clay cap be installed over the surface during decommissioning operations. The retrievably stored TRU waste is not covered by a limit because it will be disposed of offsite. 
Table III-7. Annual Disposal Limits for Beta-Gamma Emitting Radionuclides in the Solld Waste Disposal Facility

Radionuclide

${ }^{137} \mathrm{Cs}$

${ }^{90} \mathrm{Sr}$

${ }^{60} \mathrm{Co}$

${ }^{3} \mathrm{H}$

Other nuclides with

$\mathrm{T}_{1 / 2}>10$ years

Other nuclides with

$\mathrm{T}_{1 / 2}<10$ years

Fission products

(Half-lives $>1$ year)

Activation products

(Half-Lives $>1$ year)
50

Limit, $\mathrm{Ci}$

50

60,000

100,000

1,000

500,000

7,500

40,000 


\section{Offsite Waste Criteria}

Waste shipments of LLW from DOE-specified generating sites are received and buried in trenches with SRS LLW. Offsite LLW is still specified to contain $<10 \mathrm{nCi} / \mathrm{g}$ of transuranic isotopes, even through the TRU waste limit has increased from $10 \mathrm{nCi} / \mathrm{g}$ to $100 \mathrm{nCi} / \mathrm{g}$. Waste containing between 10 and $100 \mathrm{nCi} / \mathrm{g}$ of TRU isotopes must be packaged for retrievable storage. Drums containing $>0.2 \mathrm{Ci}$ and boxes with $>0.8 \mathrm{Ci}$ are considered on an individual basis. All acidic solids must be neutralized, and packages conteining free liquids are not accepted. Biologically pathogenic or infectious materials and pressun $z$ ed containers are not acceptable for burial. A special request must be made before pyrophoric and potentially explosive material is shipped, to allow SRS to evaluate and determine if the material is acceptable for receipt. Hazardous wastes defined in 40 CFR 260-261, Identification and Listing of Hazardous Wastes, such as heavy metal compounds (lead, mercury, etc.), characteristic, and listed wastes are not acceptable.

\subsection{CURRENT AND FUTURE PLANS}

\section{New LLW Storage/Disposal Facility}

Due to maintenance activities and cleanup work occurring across the site, the existing SWDF (643-7E) will reach its capacity for intermediate-level waste and LLW by September 1992. In addition, current disposal practices (shallow land burial) are inconsistent with new DOE guidance, revised $5820.2 \mathrm{~A}$ performance requirements, and current disposal concepts being proposed by compact states for commercially generated LLW. The need for engineered barriers, in conjunction with favorable site characteristics, is emphasized to isolate the waste from the environment.

A 100-acre site due north and contiguous with the present SWDF is being developed to meet projected SRS solid low-level radioactive waste storage/disposal requirements for the next 20 years. The site is located within the $\mathrm{F}$ and $\mathrm{H}$ separations areas, which include the radioactive waste disposal facility, the Mixed Waste Management Facility, and the F- and H-Area seepage basins closure sites (Figure III-20). This facility is designed to meet the performance objectives of DOE Order $5820.2 \mathrm{~A}$, including the EPA-proposed $4 \mathrm{mrem} / \mathrm{yr}$ effective dose equivalent for groundwater at the facility's perimeter.

The project includes site work (fencing, lighting, monitoring wells, railroad spur and siding, and access roads) and the initial waste storage/disposal units (intermediate-level, long-lived, support equipment, and design of the low-level nontritium waste disposal unit).

The current SWDF practice of dividing wastes into low- and intermediate-level fractions will be expanded to include new classifications as shown in Figure-III-21. The four waste categories provide for the segregation and storage of tritiated and long-lived wastes, which is necessary to meet the groundwater performan e objectives of DOE Order 5820.2A. Initial disposal units will consist of below-grade, concrete vaults designed to have sufficient strength to withstand stresses of final closure. The storage portion of the facility will consist of concrete vaults and storage buildings. Each waste category will be handled as follows: 


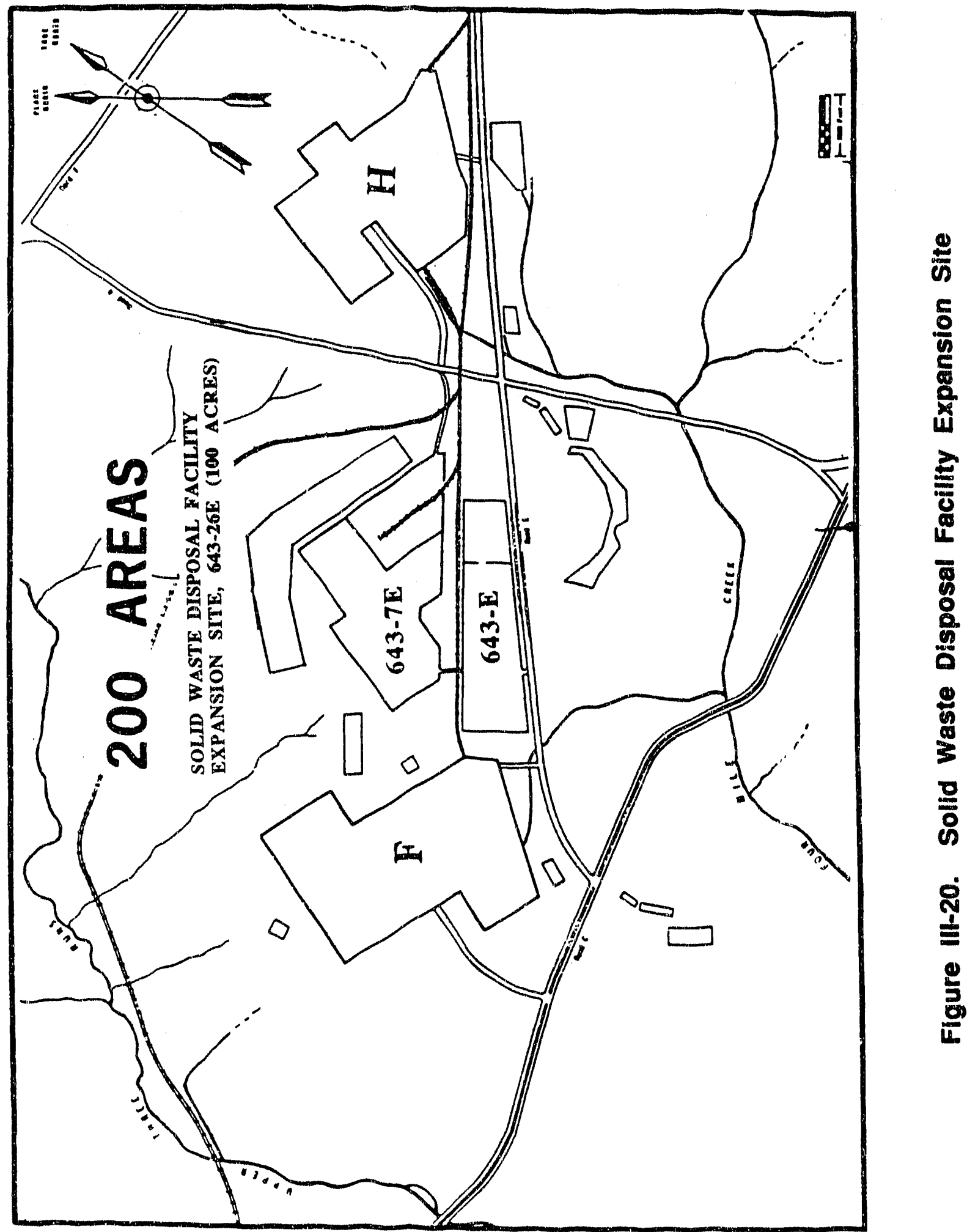


Savannah River Site

Interim Waste Management Program Plan
III. Radioactive and

Mixed Waste Management

May 1992

- Intermediate-Level Nontritium (ILNT) Waste will be disposed of in a total of ten below-grade concrete vaults. The vaults will be further divided into seven cells, each measuring $25 \mathrm{feet}$ long $\times 46$ feet wide $\times 28$ feet high. (The SWDF Expansion project will provide the initial vault with two years' capacity.) The waste will be delivered by trucks and emplaced by a mobile gantry crane designed to straddle the vault cells. Each cell will be protected by a removable metal rain cover. Wastes will be grouted in place to reduce the potential for contamination, minimize sky shine, and provide a working surface for the next layer of wastes. This operation is essentially the same as the current GCD-engineered trench operation.

- Intermediate-Activity Waste will be disposed of in a new onsite radioactive waste storage and disposal facility in September 1992. The new site being developed will include a total of ten concrete vaults over the lifetime of the facility ( 20 years). The initial vault will be 28 feet in diameter $\times 46$ feet wide $\times 50$ feet long and will accommodate a number of different tritium wasteforms. All wastes will be packaged in metal containers prior to receipt at the disposal facility and emplaced using a mobile gantry crane. The primary waste-form will be a cylindrical-shaped stainless steel crucible ( 20 feet long $\times 18$ inches in diameter) used in tritium recovery. These crucibles will be placed inside silos with the vault to provide shielding and contamination control. An open portion of the vault, covered with shielding fees, will be used to store nonstandard size containers and wasteforms.

Maintaining tritium waste in a dry environment is essential to meeting groundwater performance objectives for the long-term storage of this waste (100 years). The initial vault will contain a sump to remove the water accumulations and a sheet metal raincover to maintain wasteforms in dry condition. The vault is to be constructed a minimum of ten feet above the 100-year historical high water table. A french drain or similar concept will provide a capillary break between the vault and surrounding soil to further reduce the potential of perched water in the vault.

- Lew Activity Waste (LAW) will be disposed of in twenty below-grade concrete vaults, each measuring 648 feet long $\times 145$ feet wide $\times 25$ feet high. Each vault will contain twelve 54 -foot wide cells. Vaults will be constructed on poured-in-place concrete pads with sidewalls. Precast concrete girders and roof panels will support an 18-inch thick, poured-in-place concrete roof over each vault. The project will provide the initial vault, which will contain one year of capacity. Most low-activity waste will be delivered in 4-foot x 4-foot x 6-foot steel boxes and will be stacked four high using an extendable boom forklift. All waste will be containerized. This operation is similar to the current ELLT Operation for low-activity waste.

- Long-Lived Waste will be placed by forklift on a concrete pad enclosed by a 50-foot $\times 50$-foot x 21-foot high metal building. The project will provide the first of seven buildings. Wastes will be containerized to prevent the release of contamination and provided with adequate shielding.

Figure III-22 is a layout of the facility. Currently, site preparation is under way. Excavation for the initial intermediate level vaults has been completed. 
Savannah River Site Interim Waste Management

Program Plan
III. Radioactive and

Mixed Waste Management

May 1992

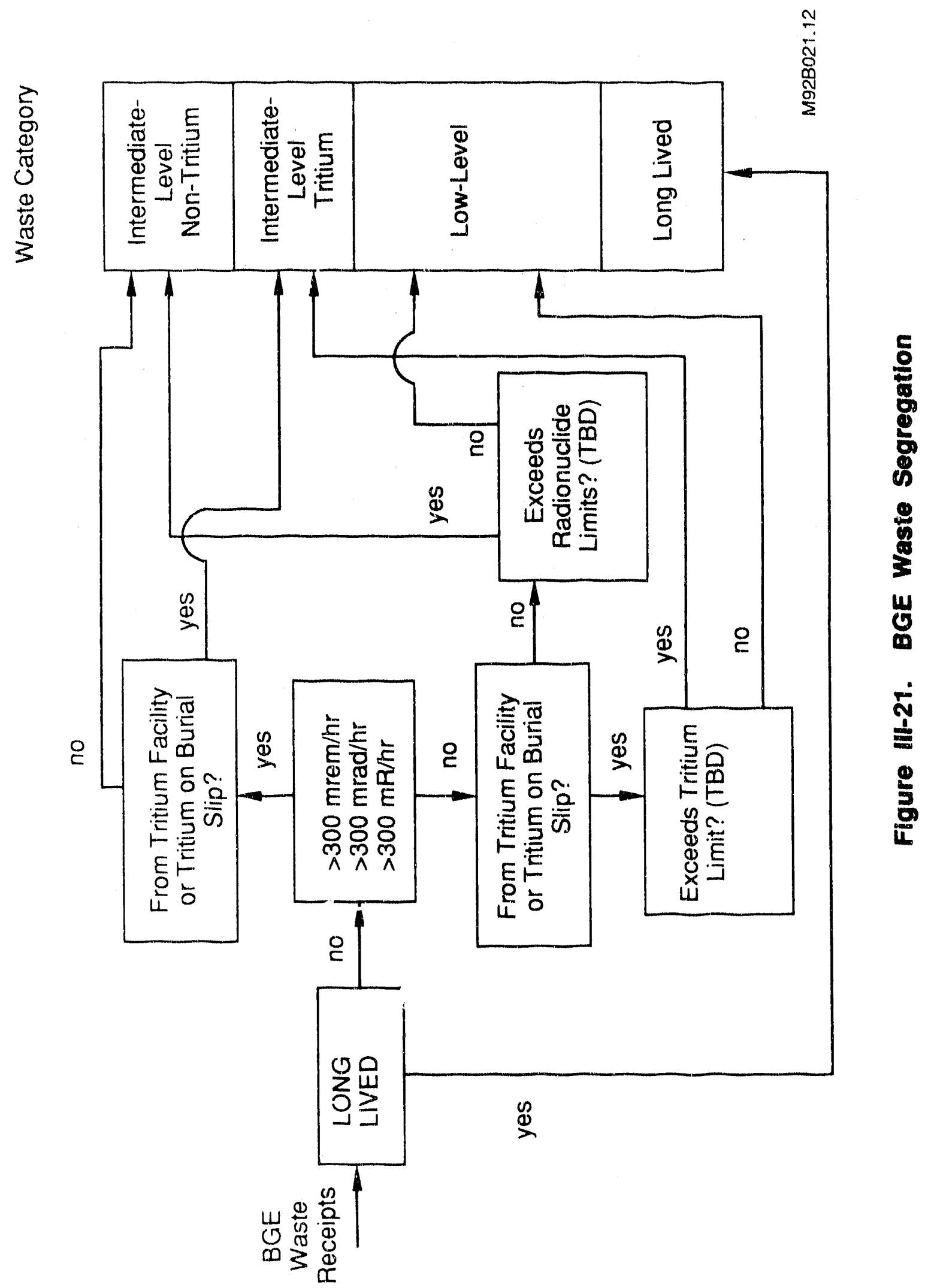

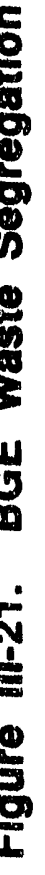


Savannah River Site
interim Waste Management
Program Plan
III. Radioactive and Mixed Waste Management May 1992

\section{Waste Preparation Facility}

The Waste Preparation Facility (WPF), currently scheduled to be an FY 1995 line item, will provide SRS with a facility to volume reduce solid, nonhazardous LLW, excluding LLW containing $>10$ nanocuries of alpha emitting waste/gram of waste. The facility will package the LLW in accordance with the WAC established for the SWDF Expansion vaults.

The WPF will replace the existing compactors at SRS, which are reaching the end of their useful life. The WPF will consist of two waste handling modules which allow for construction of both modules or each module separately. Module I will process contact-handled waste and have limited capability to size reduce equipment. Module II will provide SRS with the capability to volume reduce remote-handled waste.

\section{Consolidated Incineration Facility}

The CIF will be built at SRS to treat various site-generated combustible wastes before final disposal and to reduce the volume of the current inventory of wastes stored at SRS. The wastes to be treated will include wastes defined as hazardous by South Carolina Hazardous Waste Management Regulations and federal Resource Conservation and Recovery Act (RCRA) regulations, wastes contaminated with low levels of beta-gamma radioactivity, and mixed wastes that are both hazardous and low-level radioactive. The facility will not treat wastes containing dioxins or polychlorinated biphenyls (PCB's).

Facilities to be provided for treating the wastes consist of a main process building, which includes an area for boxed waste receipt, boxed waste handling, a rotary kiln incinerating system, including incinerator ash removal and offgas cleaning, and the necessary control room and support facilities. The rotary kiln primary combustion chamber will be used for the incineration of solids and various organic and aqueous liquid wastes. A secondary combustion chamber will also incinerate organic solvent wastes as well as destroy any remaining traces of hazardous constituents in the rotary kiln offgas. Offgas exiting the secondary combustion chamber will be cooled and treated by a wet offgas treatment system. Pollutants in the offgas will be removed to below regulatory limits before the offgas is discharged to the atmosphere. Liquid waste from the offgas system will be solidified by an interim vendor and disposed of in the Hazardous Waste/Mixed Waste Disposal Facility vaults. An area is provided for installation of an existing solidification process for incinerator ash. Facilities included on the project, but remote from the main process building, include a liquid waste storage (tank farm) area (Figures III-23 through III-26).

A low-ash, high-purity radioactive benzene waste stream generated by the DWPF will usually be incinerated in the secondary combustion chamber to use its high heating value and replace auxiliary fuel oil. The liquid waste will not contain significant quantities of hazardous metals except the DWPF benzene stream, which may contain up to $110 \mathrm{ppm}$ by weight mercury. 
Savannah River Site

Interim Waste Management

Program Plan
III. Radioactive and

Mixed Waste Managoment

May 1992

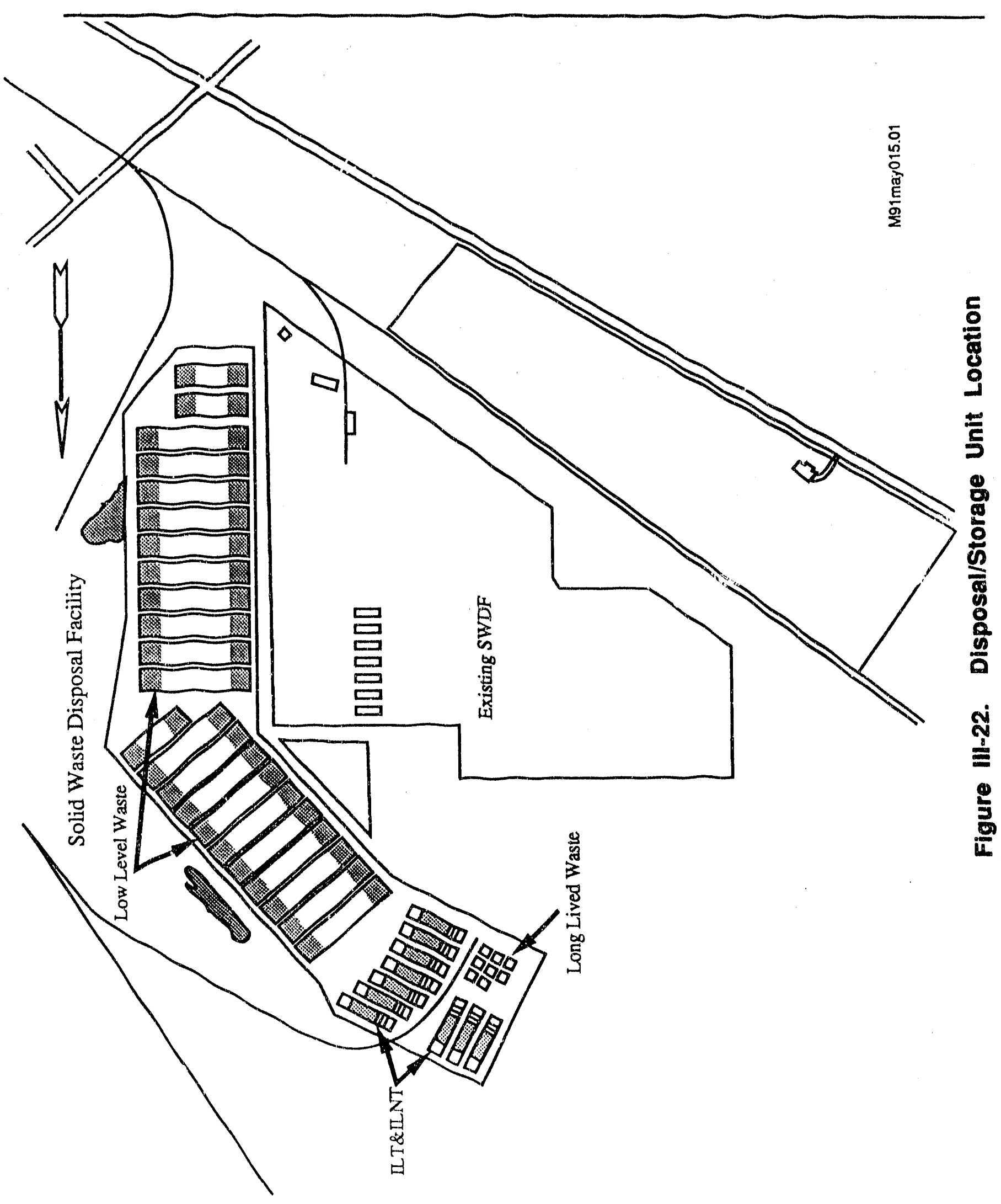


Savannah River Site Interim Waste Management Program Plan
III. Radioactive and Mixed Waste Management May 1992

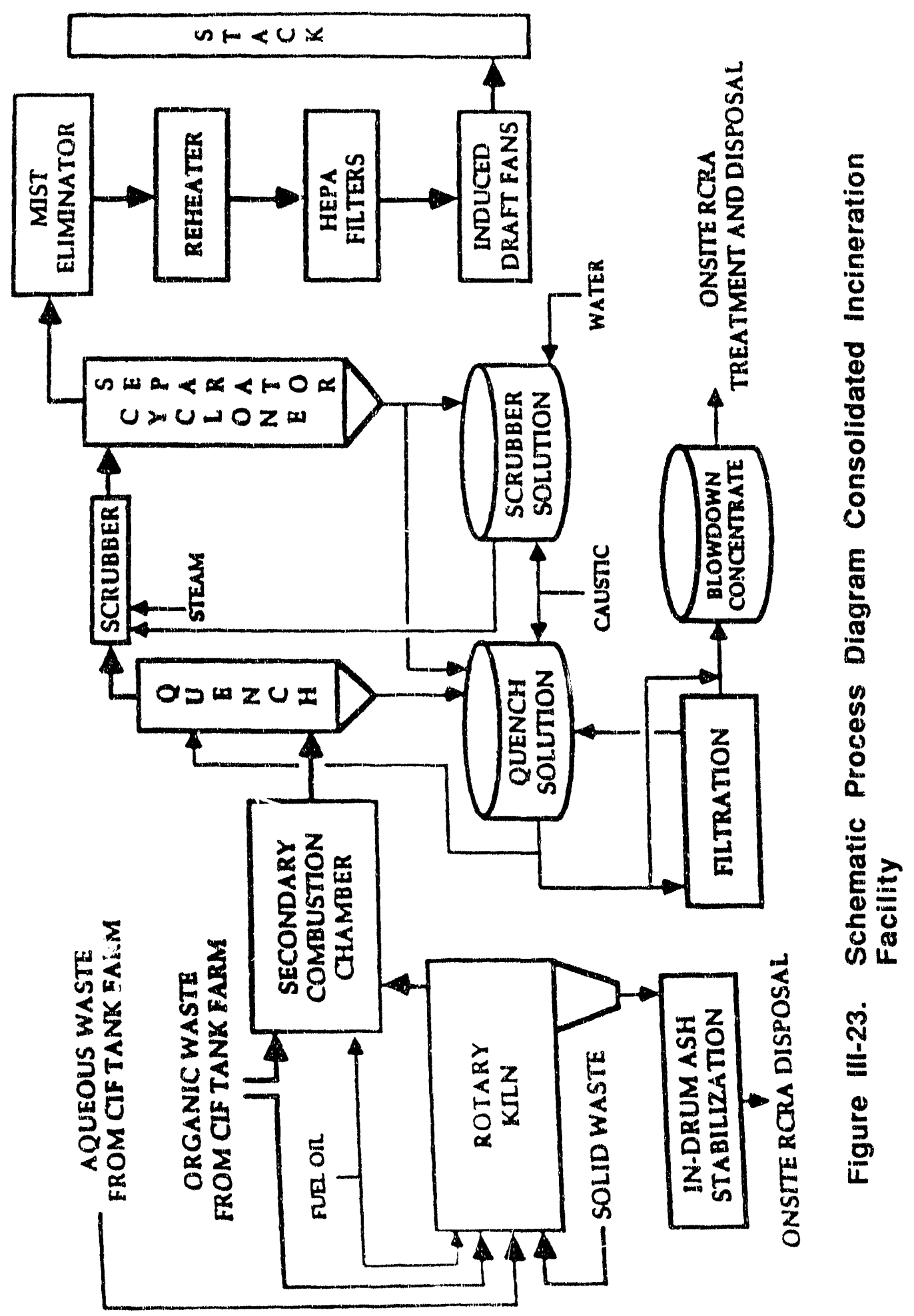


Savannah River Sito

Interim Waste Management

Program Plan
III. Radloactive and

Mixed Waste Management

May 1992

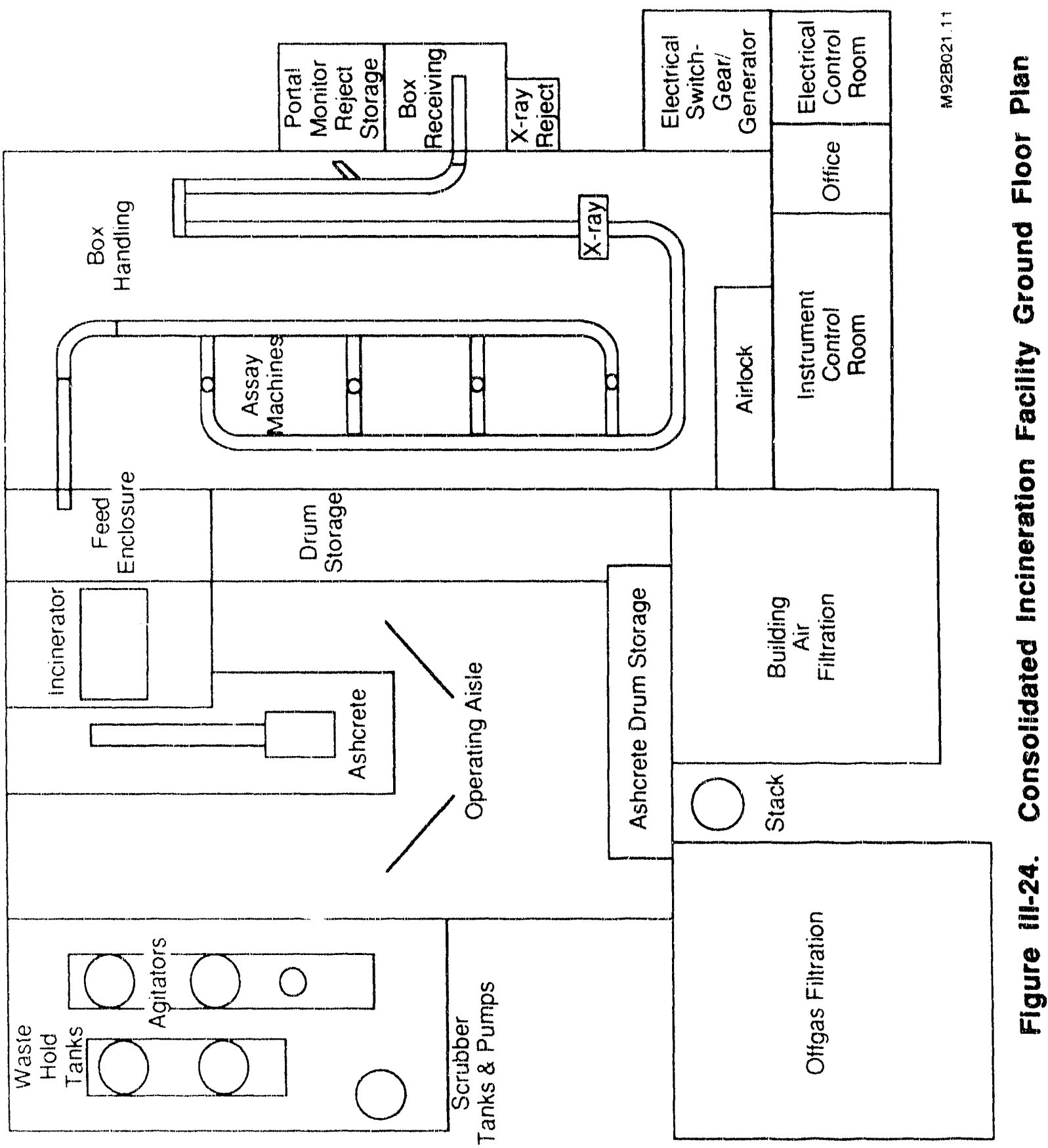


Savannah River Site

Interim Waste Management

Program Plan
III. Radioactive and

Mixed Waste Management

May 1992

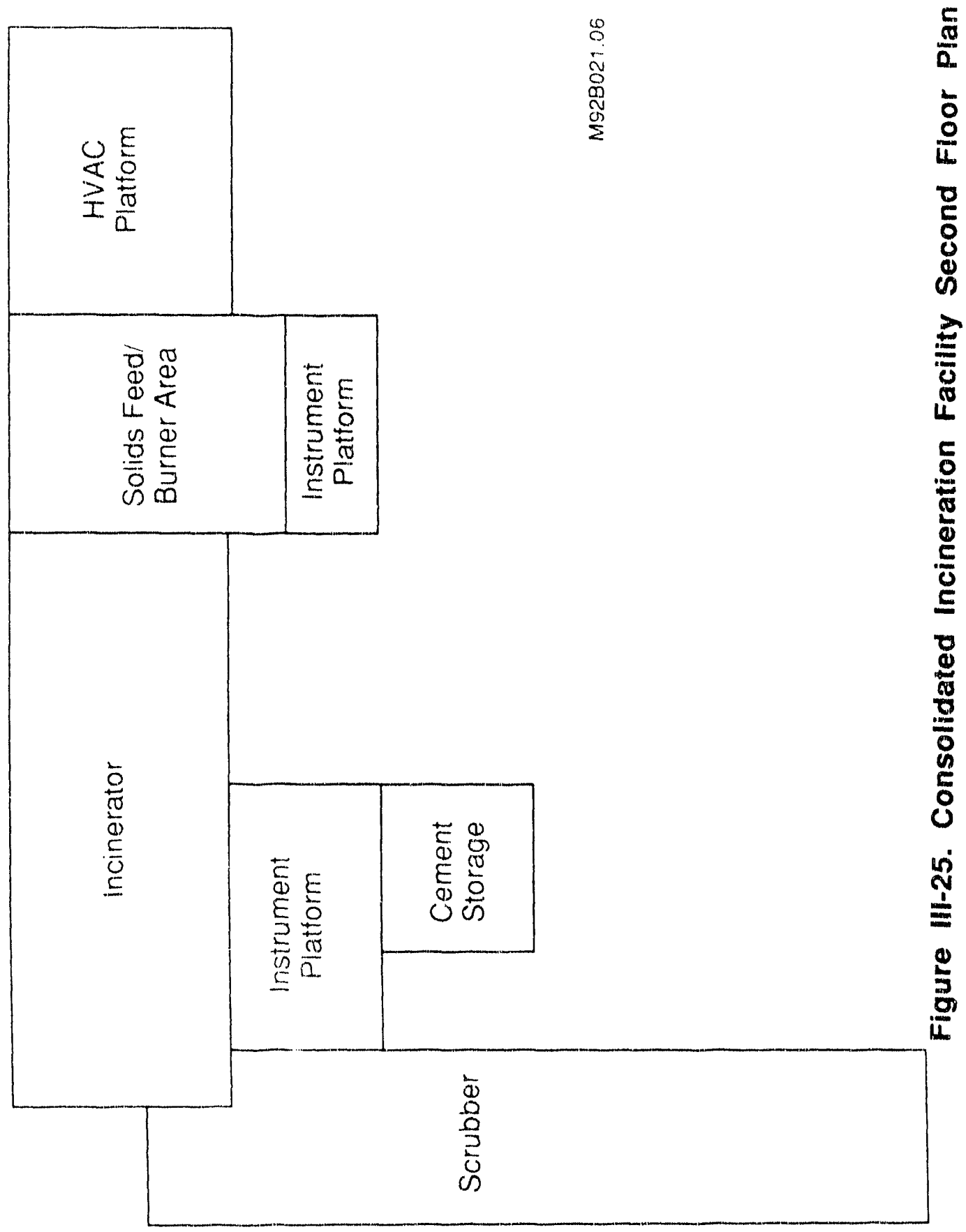




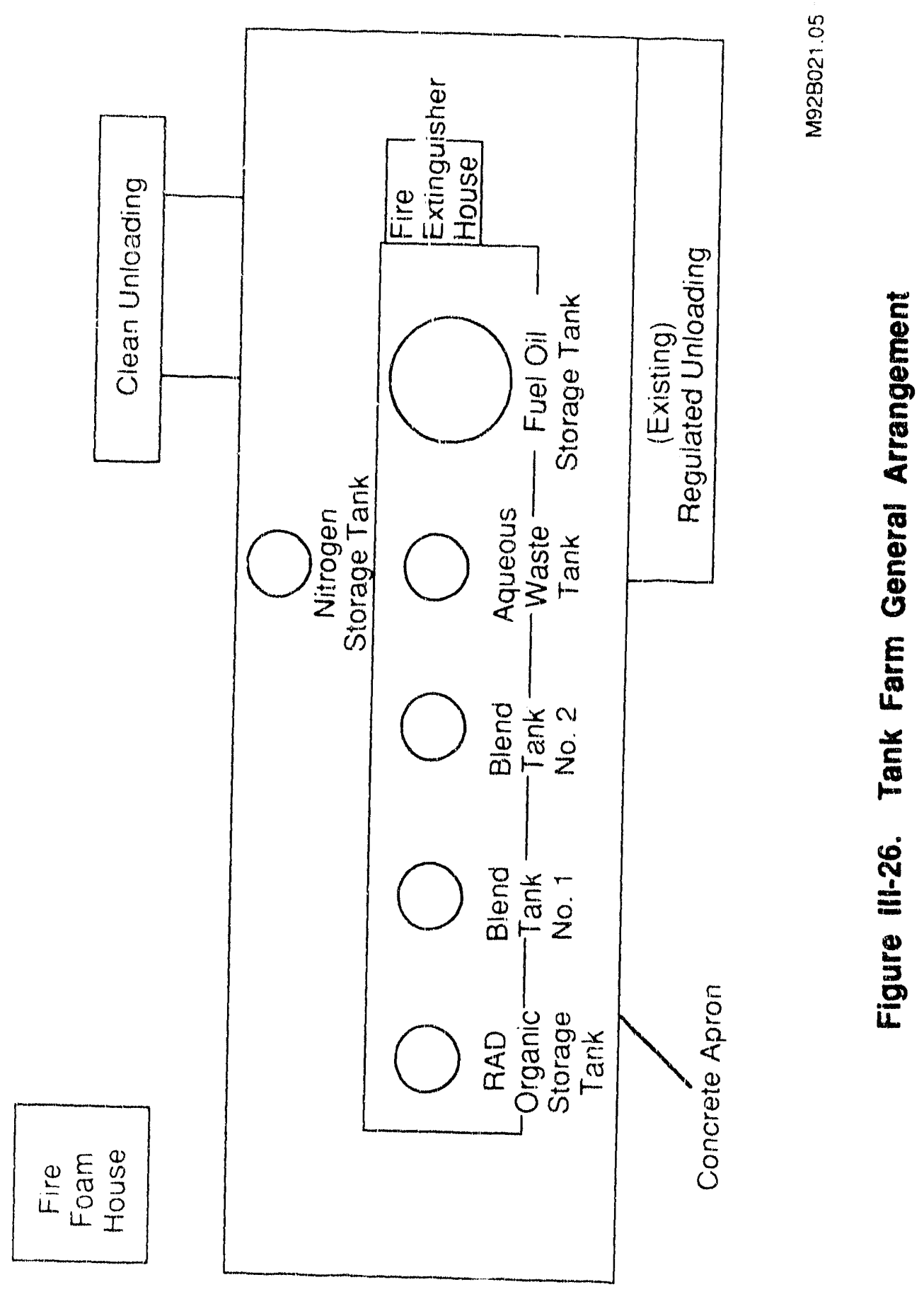




\section{E. MIXED SOLID WASTE}

Hazardous waste as defined by SC Hazardous Waste Management Regulations, i.e., lead, cadrnium, and mercury, that is also radioactively contaminated is designated mixed waste and is segregated for storage in SCDHEC-permitted facilities until a treatment and disposal facility can be constructed. The Hazardous Waste/Mixed Waste Disposal Facility (HW/MWDF) will be designed to eliminate the storage of newly generated and untreated hazardous and mixed wastes. The $\mathrm{H}^{\prime} \mathrm{V} /$ MWDF Phase I-Disposal Vaults are scheduled to begin turnover for operations in FY1Q94, and the HW/MWDF Phase II-Treatment Building is scheduled to be turned over for operation in late 1995-1996. The CIF is scheduled for completion in late 1993; the incinerator will be used to detoxify and volume-reduce radioactive, hazardous, and mixed waste. Buildings $643-29 \mathrm{E}$ and $709-2 \mathrm{E}$ are presently storing intermediate- and low-activity mixed waste, respectively. HLW is also considered a mixed waste, as is some TRU waste.

\subsection{Mixed Solid Waste Storage}

\section{Mixed Waste Storage Buildings 643-29E and 709-2E}

Mixed waste (hazardous waste that is radioactively contaminated) is currently placed in interim storage at Buildings 643-29E in Solid Waste Disposal Facility 643-7E and Building 709-2E in the Central Shops area. Waste is contained in drums, concrete culverts, and large metal boxes. These are SCDHEC permitted facilities and will be in use until the completion of the Hazardous Waste/ Mixed Disposal Facility and the Consolidated Incineration Facility.

\section{Mixed Solid Waste Inventory}

The mixed waste storage inventories for Buildings $643-29 \mathrm{E}$ and $709-2 \mathrm{E}$ as of December 31 , 1991 are shown in Tables III-8 and III-9. Building 643-29E began receiving waste in March 1987 and building 709-2E began receiving waste in June 1987 . 


\section{Table III-8. Mixed Waste Storage Building 643-29E Inventory (12/31/91)}

Yaste Type

Failed PCB capacitor

$I \mathrm{CB}$ equipment

HCB contaminated

Floor sweepings

Tritiated oil

Tritiated oil

Tritiated oil

Tritiated oil

Tritiated oil

Tritiated oil

Tritiated oil

Gold traps

Scintillation soln

Process beds

Proce is beds

Process beds

Process beds

Failed pump(s)

Tritiate I water/silica gel

Soil bo ing

Lead \& equip. w/lead

Lead \& \&uip. w/lead

Lead di ( quip. w/lead

$S$ wipes w/mercury

Methan )

Waste oil

Silver $n$ irate coated

beryl $s$ ddles and lead

Enrichec U w/chromium
Container Size

$85 \mathrm{gal}$

$55 \mathrm{gal}$

$55 \mathrm{gal}$

$26 \mathrm{gal}$

55-gal box

60-gal box

35-gal in

55-gal overpack

60-gal in.

85-gal overpack

35-gal in

6()-gal overpack

28()-gal in

612-gal overpack

54-gal vessel

55-gal drum

464-gal box

390-gal box

330-gal box

185-gal box

330-gal box

155-gal box

112-gal box

60-gal box

52-gal cyl. box

$673 \mathrm{gal}$ metal box

55-gal drum

394-gal metal box

166-gal metal box

55 - gal drum

55-gal drum

55-gal drum

55-gal drum

55-gal drum
Ne. of Containers

1

7

5

27

2

26

15

1

\section{1}

14

14

\section{1}

1

1

1

1

2

1

1

15

11

2

1

1

22

2 
Table III-9. Mixed Waste Storage Building 709-2E Inventory (12/31/91)

Waste Type

Filter paper

Soil cont. w/mercury

Lead \& equip. w/lead

Lead \& equip. w/lead

Lead \& equip. w/lead

Lead \& equip. w/lead

Lead contaminated $w /$ mercury

Spent filter cartridges

Mercury \& equip.

Sampler boxlead

Sampler box/lead

Hydraulic oil/oil dry

Cadmium plated filters

Cadmium plated filter housing

Wipes w/chromate

Wipes w/mercury

Soil borings

Tritiated oil

Tritiated oil

Hydraulic oil

Scintillation soln

Plating line sump matl.

TCE

Waste Freon ${ }^{\mathrm{TM}}$

Waste oil

Waste oil

Waste oil/oil dry

Contaminated soil

Contaminated soil

Ho ivy water w/mercury

Solids contaminated $w /$ mercury

Rags contaminated $w /$ solvents

Mixed solvents

$\mathrm{U}$ in soln. $\mathrm{w} / \mathrm{Cr}$

Calcium metal

Sludge (pending analysis)

TLD badges

Leald batteries

\section{Container Size}

673-gal metal box

55-gal metal box

673-gal metal box

394-gal metal box

156-gal metal box

55-gal drum

55-gal drum

55-gal drum

673-gal metal box

479-gal metal box

718-gal metal box

673-gal metal box

673-gal metal box

673-gal metal box

166-gal metal box

55-gal drum

55-gal drum

55-gal drum

35-gal in

55-gal overpack

55-gal drum

55-gal drum

55-gal drum

55-gal drum

55-gal drum

55-gal drum

55-gal drum

5.5-gal in

8()-gal overpack

55 -gal drum

166-gal metal box

673-gal metal box

55-gal drum

55-gal drum

55-gal drum

55-gal drum

55-gal drum

55-gal drum

55-gal drum

55-gal drum

55-gal drum
No. of Containers

93

1

33

32

17

14

1

4

2

10

15

1

6

4

1

1

1

3

1

73

3

7

1

2

5

61

2

5

22

1

46

18

1

5

8

2 
BLANK

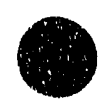


IV. NONRADIOACTIVE HAZARDOUS WASTE 


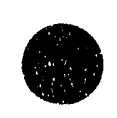

BLANK

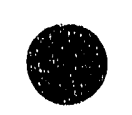

$-98-$ 


\section{NONRADIOACTIVE HAZARDOUS WASTE}

Nonradioactive hazardous wastes are wastes that have been classified (designated) hazardous by the Environmental Protection Agency (EPA) regulations (4) CFR 261) and are not clissified as radioactive. Hazardous waste may pose a substantial threat or potential hazard to human health and the environment when improperly treated, stored, disposed of, or otherwise managed. These wastes are listed or designated hazardous by EPA or the State, or have characteristics which make them toxic, reactive, ignitable, or corrosive.

\section{A. NONRADIOACTIVE HAZARDOUS WASTE STORAGE}

\subsection{Nonradioactive Hazardous Waste Buildings}

Nonradioactive hazardous waste is stored onsite in three SCDHEC-permitted storage buildings (Buildings 710-U, 709-G, and 709-4G, and area adjacent to Buildings 709-G and 4G). The RCRA Part B Permit was received for these buildings on September 30, 1987. The buildings are constructed with sloped floors, dikes, and sumps to provide adequate containment in the event of a spill. Effective separation of incompatible waste is provided. The waste storage containers are primarily 5-gallon and 55-gallon Department of Transportation (DOT) approved containers. Many of these containers are inside 83-gallon overpacks which serve as secondary containers for those containers of questionable integrity.

The site currently has a contract with an offsite vendor to ship some of the hazardous waste offsite for treatment and disposal. This allows the site to maintain its current capabilities of storing hazardous waste without having to add more storage facilities.

A Hazardous Waste/Mixed Waste Facility is currently being designed to treat and dispose of hazardous and mixed waste. The project will provide RCRA-permitted treatment and disposal for solid hazardous and mixed waste that cannot be disposed of in existing or planned facilities. The facility will also eliminate the need to transport hazardous waste offsite. The project is divided into two phases: Phase I is the Disposal Vaults, and Phase II is the Treatment Building..

The Treatment Building will contain equipment and processes that will be able to treat hazardous and mixed waste streams so that the waste will be in a suitable form to be disposed of in the vaults. Not all equipment and processes have as yet been identified. An effort is currently under way to identify current and future hazardous and mixed waste streams so that the proper equipment and processes can be developed.

The waste treated by the CIF and the Treatment Building will be disposed of in disposal vaults that will be built as Phase I of the Hazardous Waste/Mixed Waste Facility. A minimum of two above-grade vaults will be built. Additional vaults may be added as separate projects in the future. 


\subsection{Nonradioactive Hazardous Waste Inventory}

The hazardous waste inventory for Buildings 710-U, 709-G, and 709-4G as of December 31, 1991 , is shown in Table IV-1.

Table-IV-1. Nonradioactive Hazardous Waste Storage Bulldings Inventory (as of 12/31/91)

\begin{tabular}{lccc} 
Building & $\begin{array}{c}\text { Total 55-Gallon } \\
\text { Drum Inventory }\end{array}$ & $\begin{array}{c}\text { Total 5-Gallon } \\
\text { Drum Inventory }\end{array}$ & \% Capacity \\
\hline $710-\mathrm{U}$ & 260 & 11 & 39 \\
$709-\mathrm{G}$ & 533 & 3 & 58 \\
$709-4 \mathrm{G}$ & 1500 & 2 & 97 \\
Total & 2293 & 16 & 194
\end{tabular}


V. SANITARY WASTE 
BLANK

$-102-$ 


\section{SANITARY WASTE}

\section{A. SANITARY WASTE LANDFILL}

The SRS operates its own sanitary waste landfill. The landfill is divided into three sections, the original landfill, the southern expansion and the northern expansion. The original landfill has rached capacity. The southern expansion is currently being used and, at current waste generation rates and disposal methods, is expected to be full by June 1992. At that time, the northern expansion will be utilized. The section is expected to provide capacity until 1997 if current generation ates continue. The northern expansion will cease operation when the New Sanitary Landfill is available.

The existing landfill site has documented groundwater contamination and is currently operating under the permit conditions of SCDHEC permit number DWP-087A which was submitted to SCDHEC in July 1989. Concentrations of at least one of the following constituents, tritium, gross alpha, and trichloroethylene in excess of the primary drinking water standard were observed in at least one well monitoring the landfill in the first half of 1989. All three of these constituents have been detected in elevated levels at the same wells in more than one quarter. The existing monitoring well network is to be evaluated to determine its acceptability to current state and federal regulatory requirements. Should assessment of the existing monitoring well network prove inadequate, the monitoring well network shall be modified to meet applicable federal and state regulatory requirements.

The New Sanitary Landfill will provide a 20-year capacity for sanitary waste disposal in accordance with rigorous Federal and SCDHEC requirements. The landfill will incorporate a synthetic liner and leachate collection system to satisfy the new requirements of RCRA Part D and the SC Solid Waste Management Act of 1991. A performance assessment system will monitor for leaks in the liner. The New Sanitary Landfill will be available in 1996.

\section{B. TECHNOLOGY}

New methods in sanitary waste handling and disposal are being implemented to extend the life of the northern expansion. The technology that will be employed is the pit method. This method has been developed, tested, implemented, and proved at landfills throughout the ccuntry in a variety of topographies and geologic formations. A waigh scale system will be used to determine how much waste is being disposed in the landfill. 


\section{BLANK}

-104 - 


\section{ENVIRONMENTAL AND MONITORING PROGRAMS}




\section{BLANK}

$-106-$ 


\section{ENVIRONMENTAL AND MONITORING PROGRAMS}

\section{A. LIQUID RADIOACTIVE WASTE}

The following section relates to the measures taken to detect releases to the environment or changes in the process that could cause a release.

\subsection{Automatic Controls and Alarms}

Most readings of primary interest are transmitted to the central control room in each of the two tank farms. Quantitative readings and alarms are provided for critical functions; for less critical functions, only alarms are provided. The basic waste tank instruments are descrioed in Appendix III for each type of tank. Some important measurements include liquid level, sladge temperature in waste receipt tanks, supernate temperatures in evaporator feed and concentrate receipt tanks, and hydrogen monitoring. Many additional data are read and recorded regularly. Instrumentation primarily for leak detection is described in more detail later in this section.

\subsection{Temperature}

Waste temperatures at several locations and elevations, and one or more tank steel wall temperatures, in each waste tank are measured by thermocouples and displayed in the control rooms. Dial thermometers are used to indicate inlet and outlet cooling water temperatures for the tank around the vent condensers and for individual cooling coil circuits.

The tank bottom steel temperature of fresh high-heat waste (HHW) receivers is recorded daily to avoid operating with the tank bottom steel temperature above the boiling point of the waste. The corrosion resistance above this temperature is uncertain. Additional bottom steel thermocouples were installed on new waste Tanks 38-51 to supplement monitoring. Twenty-nine special bottom steel and air temperature thermocouples can be recorded by a data logger for Tank $39 \mathrm{H}$, a high-heat waste receiver. Temperature and energy balance data are being obtained during each fill cycle of fresh HHW. These data will be used to better understand the thermal behavior of HHW tanks.

\subsection{Liquid Level Measurement}

For inventory control, and as a backup to the leak detection system, liquid levels inside the tanks are automatically measured and displayed or recorded by tape printout. Each waste tank is equipped with a reel tape for measuring the liquid level in the tank (except tank $16 \mathrm{H}$, which has been emptied). At least once per day, the liquid level in every tank is compared with the readings from the previous day. Additionally, tank levels are manually transcribed to data summary sheets:

- Every two hours on both evaporator feed tank and concentrate receipt tank while an evaporator is operating.

- After each delivery of fresh waste, to compare the quantity received to the quantity sent. 
- Once every hour during transfer of waste from one tank to another to compare the quantity received to the quantity sent.

A Waste Management production supervisor reviews and signs the data sheets used to record all sump and annulus levels, and the tank level measurements just listed and any required corrective actions. These data sheets are reviewed by operating and technical supervision. Daily reports on Waste Management activities are provided to operating and technical management.

An automatic reel tape is the primary method for liquid-level measurement. The device consists of an electrical probe and transmitter. The probe is positioned at different levels inside the tank by the actuation of a reel on which the tape is wound. The liquid level is detected when the probe contacts the liquid surface and completes an electrical circuit. Operation of the device is automatic and continuous. The level-seeking circuitry causes the drive motor to lower the probe until the liquid is contacted. The motor stops, and an electronic timer is activated. Following a measured time lapse, the drive motor is started in reverse, and the probe is raised until contact with the liquid is broken. The automatic level-seeking circuitry again causes the drive motor to reverse, and the probe is lowered until contact is re-established with the liquid. At that time, the cycle is repeated. Currently on tanks $40,41,42,48,49,50$, and 51, a programmable logic controller continuously monitors the tank level and prints it out as requested. For field data sheets, the operator reads the counter when the probe is contacting the liquid, i.e., when the counter is not moving. The automatic level-seeking feature reduces measurement error by removing the operator judgment factor. The repeatability of measurements with the device is about $\pm 0.1 \mathrm{inch}$.

The automatic reel tape has both high- and low-level alarm capability. Whenever the readout on the level counter coincides with one of the alarm settings, an alarm will sound. This feature allows detection of both unexpected tank level increases and decreases. The reel tape assembly is also equipped with an alarm which sounds if the reel tape checking (raising and lowering) device fails to function. The alarm sounds within three minutes on a nonfunctioning reel tape.

Abnormal circumstances are sometimes involved in measuring liquid levels in waste tanks. Salt tanks pose particular problems whenever salt buildup extends above the liquid surface. In such a case, the reel tape probe may contact the salt, giving an erroneous liquid level indication. In tanks with exposed salt formations, it is also possible for the probe to contact a pool of liquid isolated by the exposed salt at a different level from most of the liquid in the tank. Salt accumulation on the end of the probe, increasing its effective length, must be considered as a possibility for error. We now have a program to park the reel tape in tanks with dry salt or sludge (i.e., no free liquid) approximately $1 / 2$ inch above the waste surface. Thus, the reel tape acts as a fixed conductivity probe that will detect liquid inleakage (there is no concern about the immobile solids level decreasing). The tanks are steel-taped monthly.

Because of the possible sources of false level indications with the reel tape system, backup level measuring methods are used (at least monthly) to determine if a false level is being read and to allow for correction of the error. The most frequently used and most reliable backup is the hand tape method. A metal disk attached to a steel measuring tape is lowered into the tank through a tank riser, and the liquid level is deteried by sight and/or touch. Stationary conductivity probes, either resting on insulators or suspended by cables, are widely used to detect liquid in normally dry areas, or as a backup to the reel tape to prevent tank overfilling. 


\subsection{Salt and Sludge Level Measurements}

The primary methods used to determine submerged salt and sludge levels are soundings with the hand-held tape and vertical temperature profiles. The sludge level can also be determined with an ultrasonic interface detector. Silt and sludge soundings are made in the same manner as liquidlevel measurements with the hand-held tape and disk, except that weight is added to the disk to help distinguish between the liquid surface and the salt or sludge surface. Vertical temperature profiles are plots of temperature versus distance above the tank bottom. Temperature change can show the interface between solid and liquid. Temperature profiles are obtained by inserting a length-graduated thermocouple wire into existing tank thermowells and measuring the temperature at several positions.

An ultrasonic interface detector was used in Tank $42 \mathrm{H}$ during the sludge processing demonstration. This method, developed by the Equipment Engineering Department (EED) at SRS, lowers a shielded ultrasonic transducer/receiver into the waste tank on a graduated cable. The attenuation of the ultrasonic pulse is proportional to the quantity of solids in solution. The location of settling sludge supernate interfaces and the depth of thick sludge layers can both be determined by this method. When the attenuation of the ultrasonic pulse (seen on a digital ultrascope) changes, sludge solids have been encountered by the transducer/receiver. The location of the sludge supernate interface is then determined from the length of cable that was lowered into the tank.

\subsection{Hydrogen Monitoring}

Radioactive decomposition of wastes evolves hydrogen gas. The rate of gas evolution is dependent on several factors, the age of the waste being the principal one. The gas generated is easily handled and dissipated by the ventilation systems. Nevertheless, the unlikely event of hydrogen gas buildup (to explosive levels) must be guarded against. $\mathrm{H}_{2}$ detection instrumentation is installed on all Type III tanks and other selected tanks to alert personnel to any dangerous level of gas buildup. In addition, all tanks and waste enclosures are monitored periodically using portable gas samplers.

Limiting concentrations for safe handling of gaseous hydrogen in air are defined by flammability limits. The flammability limit is generally taken as $4.1 \mathrm{vol} \%$ hydrogen in air.

\subsection{Waste Sampling}

To ensure that waste tank chemistry is not deleterious to the waste tank steel, all waste tanks which contain liquid are sampled periodically on a scheduled basis. Fresh waste receipt tanks which receive waste throughout the year from either the canyon building or the Resin Regeneration Facility in H Area are sampled semiannually. All inactive tanks are sampled at least once every two years. Active concentrate receipt tanks, evaporator feed tanks and evaporator vent tanks are sampled at least once per year. 


\subsection{Waste Tank Leak Detection}

Of the two fundamental principles on which detection of leaked or spilled waste can be based (disappearance of material from its proper location and appearance of material in an improper location), the latter principle is more reliable because waste inventories are too large for precise measurement of the very small inventory differences that would constitute an intolerable quantity of leakage. Although rigorous inventory surveillance is practiced as a backup, primary leak detection methods rely on automatic surveillance of those areas into which leaked waste is most likely to migrate, especially the collection sumps provided for this purpose inside the multiple containment barriers of the SRS waste management system.

The annulus of each of the double-walled tanks is equipped with at least two single-point conductivity probes located at the bottom of the annulus on opposite sides of the tank. Older Type III tanks are equipped with one multilevel and three single-point conductivity probes. The newer Type III tank annuli are provided with both pneumatic level instrumentation and two conductivity probes. When a conductivity probe detects liquid, it activates audiovisual alarms in the waste management control room. Each alarm is investigated, including visual inspection of the annulus, and a formal investigation report is issued to operating and technical supervision to describe each incident and the corrective action. Monthly, all annuli are visually inspected and the conductivity probes are tested. Each of the eight single-walled tanks is located on a concrete slab with a network of leak-collection channels which drain to a common sump. The liquid level in each sump, as measured by differential pressure transmitters, is recorded continuously, and an alarm is automatically activated, if the level reaches a preset value. These sumps frequently contain groundwater inleakage and are sampled and pumped out as required.

\subsection{Periscope and Direct Photography}

Most of the leaks in the primary walls of several Types I and II waste tanks were found by visual inspection within the tank annular space. These inspections are aided, in most cases, by periscopic and/or direct photography. With rare exceptions, neither flowing waste nor cracks have been visible. However, a telltale accumulation of dried salt adhering to the wall indicates the location of each crack through which liquid waste seeped from the tank interior at one time. On reaching the unsaturated air in the annulus, evaporation of liquid and deposition of suspended sludge or salt particles sealed the cracks, and further waste leakage was stopped. The air in the annulus is maintained well above the dew point by the annulus dehumidification system. Because of the static condition of the wall-salt accumulations and the multiple-containment features of the tank, the cracked tanks are safe for waste storage until they are emptied under the Waste Removal Program. Periscopic photography was also used to detect an inleakage within a Type IV, single-walled tank. Water had apparently leaked into the tank above the liquid level. This tank is now inactive.

\subsection{Cooling System Leak Detection}

The waste tanks are equipped with cooling coils or bundles of coolers which are supplied with water from a closed-loop cooling system. The closed-loop cooling system is cooled by heat exchangers supplied with well water or (for FY 74 and subsequent tanks) with water in another closed-loop system incorporating cooling towers. 
The closed-loop water circulates at pressures above the hydrostatic pressures of the stored wastes, and leakage of a coil results in the loss of closed-loop water into a waste tank. Leakage causes a low-level alarm to sound for the closed-loop surge tank. Leaking coils are valved off, and blanks are installed to remove them from service. On two different occasions, the closed-loop water was found to be contaminated with about $3 \mathrm{Ci}$ of $\mathrm{Cs}-137$ (by diffusion of liquid waste into the residual water in the coil) when valves on the leaking coils were reopened. Most of the cesium was returned to a waste tank by flushing the closed-loop system; the remainder was either sent to seepage basins or remained in the closed-loop cooling system. A filter was installed in a side stream and has been successful in removing residual contaminants. In 37 years of operation, 85 of 608 nonreplaceable cooling coil circuits in Types I and II tanks leaked and were removed from service.

Well water or spray-tower-cooled recirculated water flows through the heat exchangers at a pressure above the pressure of the closed-loop water, and a heat exchanger leak results in the addition of well water to the closed-loop system. Leakage causes a high-level alarm to sound for the closed-loop surge tank. The heat exchangers are bypassed temporarily while leaking units are replaced.

Cooling water for the older tank farm evaporator condensers and process water for flush tank makeup and miscellaneous uses in the tank farms are supplied from the well water effluents from the heat exchangers of the tank cooling systems just described. This water is normally maintained at a higher pressure than any of the potential sources of contamination with which it comes in contact. The effluent water from the condensers is monitored for radioactivity before disposal. The monitoring arrangements in the two tank farm areas differ. In F Area, the water is used as makeup to the recirculated cooling water system supplying the main separations building, and it is monitored as part of that stream. In $\mathrm{H}$ Area, the water is discharged to a storm sewer and monitored with that stream. If necessary, the stream is diverted automatically from discard (to a surface stream) into the lined retention basin. When the H-Area monitor is out of service, the water is routed into the lined retention basin; this water is analyzed before discard to the creek. Cooling water for the new tank farm evaporator condensers is provided through a closed loop system.

Higher activity water collected in the retention basins is presently sent to the F/H Effluent Treatment Facility for disposal if it meets acceptable limits. This facility is described in section III.C.3, "F/H Effluent Treatment Facility."

\subsection{Offgas Radioactivity Monitors}

All Type III tanks are equippea with monitors to detect airborne radioactivity in the effluent air from both the primary tank and annulus ventilation systems.

\subsection{Collection Sumps on Transfer Lines and Process Cells}

Similarly, other secondary containment facilities are provided with instrumented collection sumps. These facilities include the evaporator and pump tank cells, diversion boxes, and transfer line jackets. Until recently, transfer lines that were built after completion of the original Separations plants were (with a few exceptions) provided with secondary containment, surrounding pipes of steel or concrete-asbestos, but not with readily utilized provisions for 
detection of liquid that might leak into the jackets. Some of these lines were upgraded or replaced to provide steel jackets (where not existing) and leak detection boxes or sumps with conductivity probe liquid detectors. New process lines have carton steel jackets with leak detection boxes. Each box contains a drain, an overflow; and a conductivity probe. Almost all of the jackets can be pressure tested. A program was implemented during 1989 to periodically test the integrity of all newer waste line jackets (using pressurized air).

\subsection{Surveillance and Monitoring for Contamination}

Routine visual observations and monitoring with portable radiation detection instruments, by both operating and Health Protection personnel, turn up almost all of even the very minor mislocations of radioactivity that occur in and around the waste tank farms. Operator alertness and responsible action have proved effective in detecting, minimizing, and rectifying the escape of contaminated materials from their normal confinement if they are not detected by routine monitoring. Where feasible, operating procedures cultivate surveillance by citing specific abnormalities to look for in conjunction with particular operations.

\subsection{Radiation Monitors}

To supplement the manual radiation surveys, area radiation monitors called "vamps" (or GA6 's) are located at strategic points throughout the tank farm. These detectors provide an instantaneous alarm if an increase in radioactivity occurs abovegrade. Each alarm incident is promptly investigated by a detailed survey with portable radiation monitors to locate the source of the increased radiation. A vamp has been installed above each waste tank and at each tank penetration where there is process piping or equipment. Almost all of the diversion boxes also have vamps. Redundant vamps have been placed in many locations.

\subsection{Storm Water Monitors}

Storm sewers in operating areas are subject to contamination with radioactive materials caused by spills of waste due to operating errors. The sewer drainage is segregated and monitored with continuous in-line gamma monitors. If a monitor detects radioactivity, the stream flow is automatically diverted to a sewer leading to a lined retention basin for further handling. At the retention basin, water:

- May be pumped to natural effluent streams, if free of radioactivity.

- May be pumped to the ETF, if the concentration of radioactivity is within ETF limits.

- That is contaminated may be pumped back to the tank farm for storage or processing, if the concentration of radioactivity is above the ETF limits, in the future, when HDB-8 is in service. 


\subsection{Monitoring of Groundwater in Waste Tank Areas}

Groundwater monitoring wells are located within the tank farm areas and regionally toward the existing streams. They are sampled quarterly by the Envirommental Protection Department. They are not thought of as primary leak detection methods because more sensitive and prompt indicators of tank leakage are available. The monitoring wells indicate the quality of the groundwater entering and leaving the vicinity of the waste tanks. In the event leakage to the soil is recognized or thought to have occurred, special monitoring wells are installed. In addition, earth corings are taken and analyzed for absorbed radioactivity. Figures VI-1 and VI-2 show the location of groundwater monitoring wells in $\mathrm{F}$ and $\mathrm{H}$ Areas.

\subsection{Dry Monitoring Wells}

Pipe wells closed at the lower end, through which a radiation probe can be traversed, have been installed in a few locations where waste leakage into the soil was known, suspected, or possible. Locations of the F/H-Area tank farm dry monitor wells are shown in Figure VI-3. These dry-well surveys have been useful in assessing magnitude and dimensional distribution of leaked underground radioactivity in specific cases, particularly adjacent to Tank $8 \mathrm{~F}$, Riser 6 of Tank 3F, and the CTS pump pits in both areas. The dry wells beside CTS pits in both F and $H$ Areas have been capped and are no longer monitored. Dry wells at many other locations of potential waste leakage belowgrade are surveyed periodically and have shown no radioactivity in the surrounding soil. Similar wells were installed on 11-degree intervals around and under Tanks $36 \mathrm{H}$ and $37 \mathrm{H}$, which do not have the facilities for detection of leakage from the secondary containers that are provided on subsequently constructed tanks.

\subsection{Effluent Cooling Water Monitoring}

The installation of a prototype online monitor for detecting tritium in the effluent canal from 100$\mathrm{K}$ Reactor has been completed. The monitor will detect a rapid increase in tritium concentration in the outfall from an unanticipated release of coolant. The consequences of a release would conceivably be reduced by prompt detection and alerting of plant personnel. Future development of the monitor for quantitative measurement of tritium effluent and stream concentrations in in progress.

\subsection{Realtime Detection Monitoring}

Installation of prototype realtime detection monitors in 100 - $\mathrm{K}$ effluents are expected to result in a more rapid detection of unplanned environmental tritium releases to effluent streams in the $1(0)-\mathrm{K}$ Area process sewers.

\subsection{Tritium Stack Monitoring}

New, highly sensitive stack monitors are being installed in all reactor areas. They will provide an earlier indication of system upsets and more accurate total release data. 


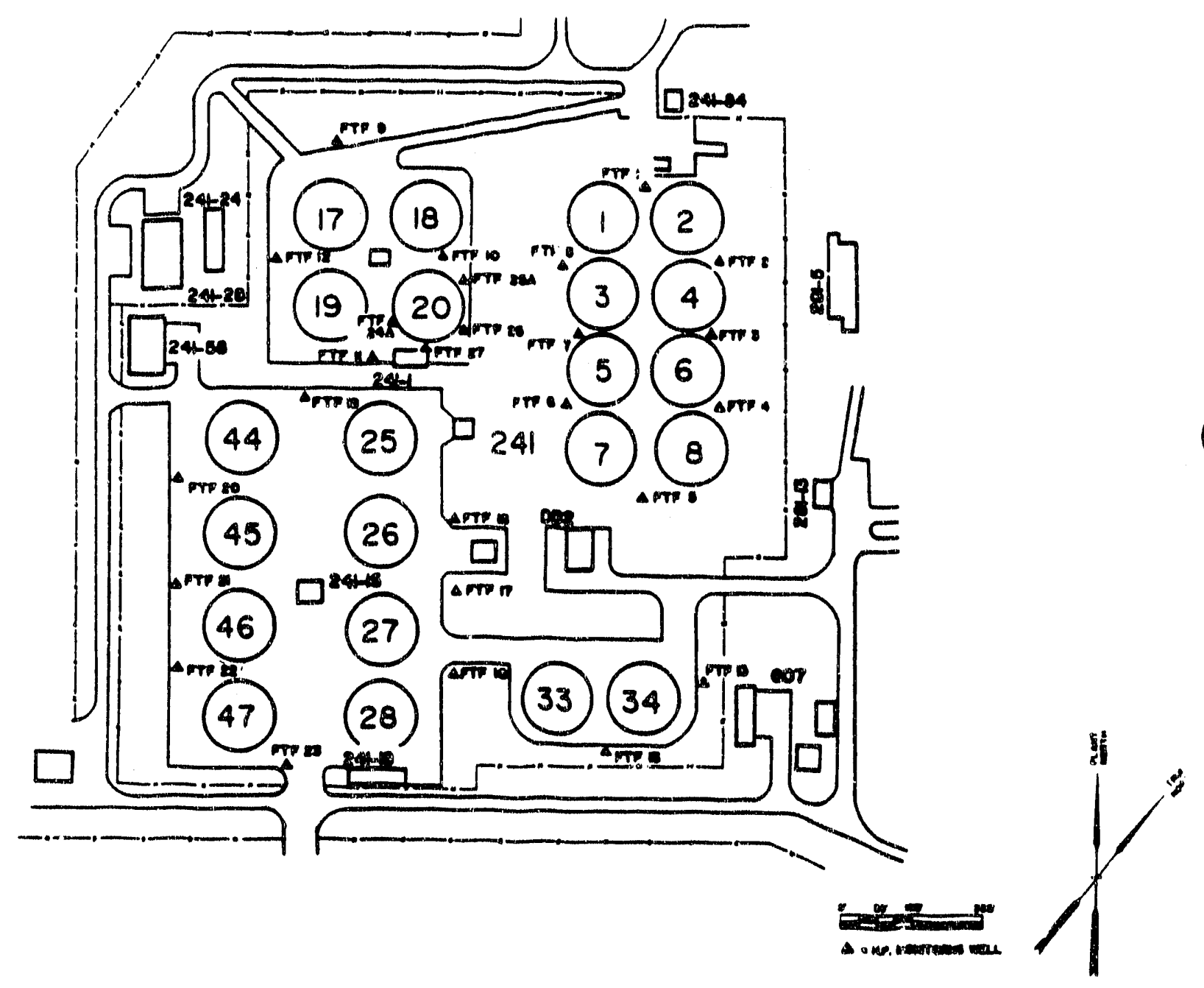

Figure VI-1. F-Area Tank Farm Groundwater Monitoring Wells 
Savannah River Site

Interim Waste Management

Program Plan--FY 1991-1992
VI. Environmental and Monitoring Programs

May 1992

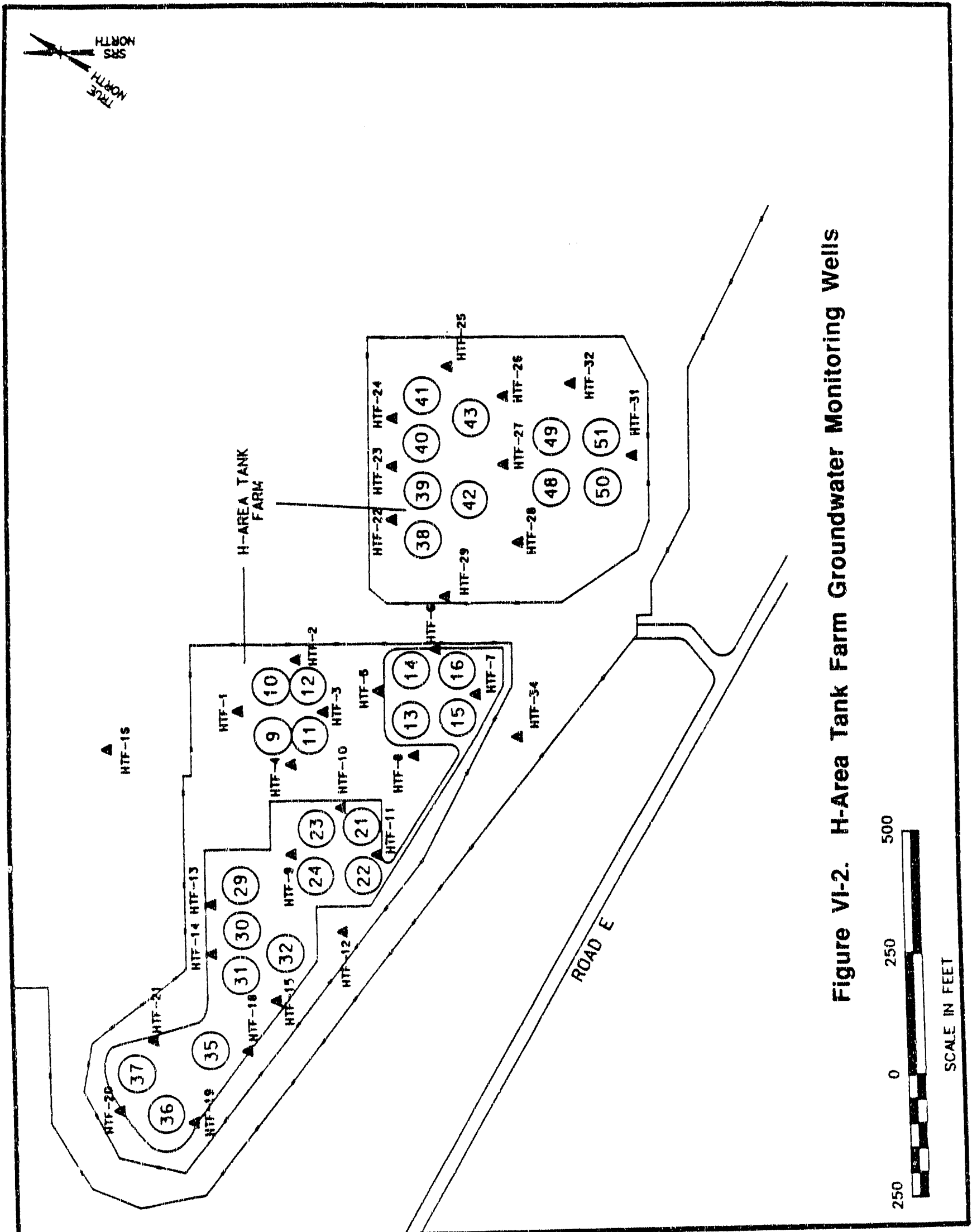




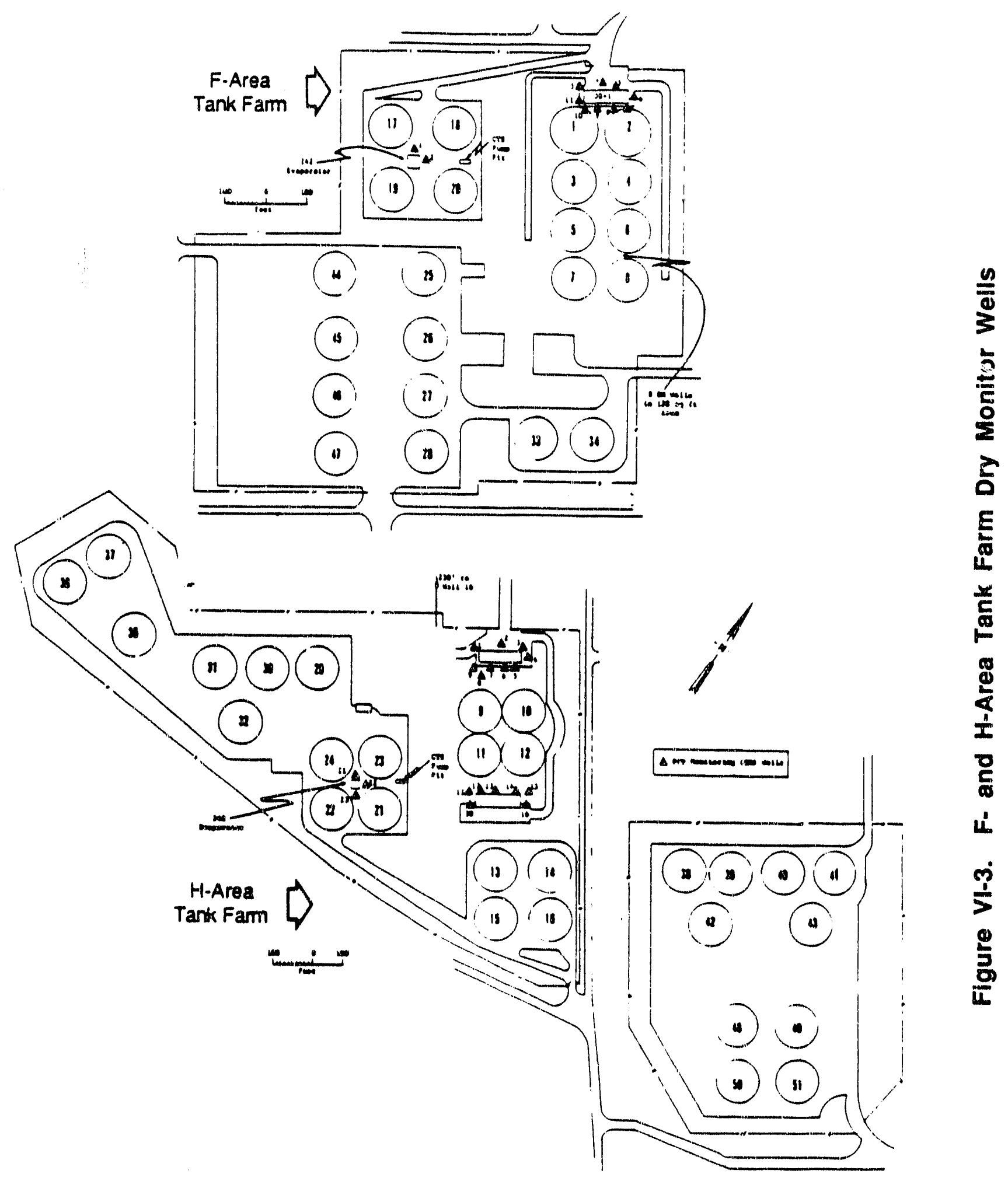




\section{B. SOLID RAIDIOACTIVE WASTE}

\subsection{Solid Waste Disposal Facility (SWDF)}

A monitoring program has been under way since startup of the low-level radioactive waste disposal facility to monitor possible migration of radionuclides from their storage locations. Well locations shown in Figure VI-4 monitor water quality in the water table. These wells are sampled and analyzed by SRL, regularly for alpha, beta, and tritium concentrations in the groundwater, and all records and documents regarding the analyses are managed by SRL.

The designation of 643-28E (an area within the present SWDF) as a Mixed Waste Management Facility (MWMF) and subsequent plans to close it under RCRA regulations have resulted in major changes in the groundwater monitoring program. Thirty-eight wells are constructed with PVC casing and have submersible pumps installed so that samples can be retrieved by pumping rather than bailing. These 38 wells monitor three aquifers: the water table and the McBean and Congaree aquifers; they comprise the Point of Compliance (POC) wells for the Mixed Waste Management Facility Closure as prescribed under RCRA. The POC wells are sampled quarterly for hazardous constituents and for radionuclides. Results will be reported to SCDHEC as part of the MWMF postclosure monitoring. Fourteen POC wells failed to produce "representative samples" of groundwater quality as required by RCRA. A program is in place to rehabilitate and/or replace these wells. Data collected at POC wells for four quarters in 1988, 1989, and two quarters in 1990 indicated elevated levels of tritium, alpha, nonvolatile beta, benzene, and TCE. A Mixed Waste Management Groundwater Assessment Plan is being written to install more ground-water wells to define the extent of contamination from the MWMF and the old Solid Waste Disposal Facility.

SWDF 643-E is currently a RCRA Facility Investigation (RFI) site, and an eventual RCRA closure is anticipated for this facility. As part of the RFI work, RCRA-type monitoring wells have been installed around the perimeter of this facility. Eventually all of the old steel-cased monitoring wells in and around this facility will be abandoned.

The SRS limits on the quantity of beta-gamma radioactivity generated at SRS and the actual quantities emplaced are given in Table III-7. The Technical Standard limits are based on maintaining the Solid Waste Disposal Facility radionuclide inventory at or below quantities used in documentation in support of DPSTSA-200-10, SUPP-8, "Safety Analysis - 200 Area Savannah River Plant Burial Ground Operations." Present information on migration rates indicates that the maximum inventory will not cause an unacceptable dose to man at the boundaries of the Solid Waste Disposal Facility after cessation of plant operations and institutional control. SRL has completed a study which indicates that vegetative uptake represents by far the most likely scenario for radionuclide transfer to man, and recommends additional backfill and a low-rainwater permeability cap be placed over the surface during decommissioning operations. The retrievably stored transuranic waste is not covered by a limit because it will be disposed of of site. 


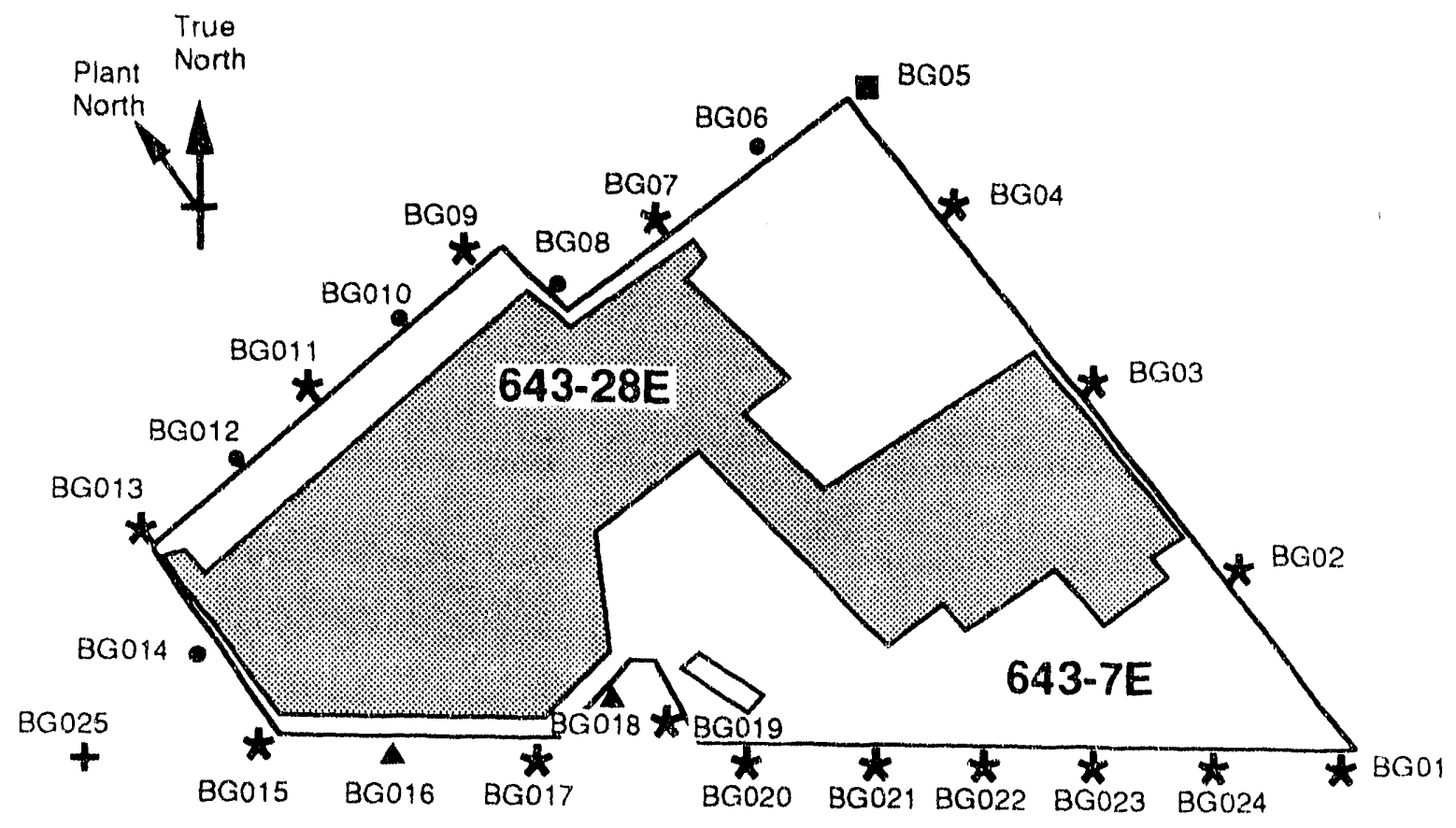

$$
\begin{aligned}
& \text { * Water Table Well } \\
& \text { Water Table Well \& } \\
& \text { McBean Aquifer Well } \\
& \text { - Water Table Well } \\
& \text { McBean Aquifer Well \& } \\
& \text { Congaree Aquifer Well } \\
& + \text { Congaree Aquifer Well }
\end{aligned}
$$

Figure VI-4. RCRA-Type Monitoring Wells 


\subsection{Sumps and Rainwater Runoff Ditches}

Rainwater runoff ditches in the SWDF are monitored before the water is discharged at the outfall. TRU pads have sumps which are checked after rainfall before they are emptied. The sumps in the SWDF are sampled for beta-gamma and alpha activity. The hazardous waste and mixed waste storage buildings contain sumps which are checked and pumped out on a weekly basis.

\section{SITE ADMINISTRATION LIMITS ON EFFLUENTS}

\subsection{Radioactive}

The SRS operating guides for release of radioactivity state values that are achievable with good operating practice. The guides are reviewed annually and increased or decreased as needed to reflect the best current operating practice, experience, and production commitments and to meet appropriate regulations.

Release guides are based on the as low as reasonably achievable (ALARA) principle. ALARA guides are authorized by the Vice President of the Environmental, Safety, Health, and Quality Assurance Division following approvals by the Manager of the Environmental Protection Department and pertinent production and technology departments. The site release practices, ALARA guides, and monitoring committee formulate ALARA goals by November of each year, based on recommendations from area environmental committees. Goals are reviewed annually or upon request by the appropriate area environmental committee and the site release practices, ALARA guides, and monitoring committee.

The ALARA program for radioactive effluent accountability emphasizes the impact radioactive releases have or offsite dose rather than simply maintaining an inventory of quantities released during the calendar year. Area and site goals, based on offsite dose, shall replace release guides that were previously used to control release quantities.

Monthly release quantities are used to calculate effective dose equivalent (EDE) for a maximum exposed off site individual. Annual site ALARA goals (EDE in mrem) are established for liquid and atmospheric releases. Each operating area is assigned a percentage of the site ALARA goal for a calendar year. Each month, year-to-date offsite dose is compared against annual goals for liquid and airborne emissions. This approach provides a month-by-month analysis of the sites impact on offsite dose.

The ALARA guides for $H$-Area liquid and atmospheric radioactive releases may be found in Table VI-1. F-Area liquid and atmospheric radioactive releases may be found in Table VI-2.

The first release standards defining quantities of radioactive materials in curies were formulated in 1959 and adopted in 1960). At this time, they were probably the most comprehensive criteria for waste disposal by a nuclear facility. These 1960 release standards were based on the recommendations of the International Commission on Radiological Protection (ICRP). The ICRP defined values of maximum permissible body burdens and maximum permissible concentrations for various radionuclides for offsite populations. Therefore, these release standards were developed so that concentrations in air, water, and food would not result in an uptake greater than the maximum permissible levels set up by the ICRP. 
Table VI-1. ALARA Guides for H-Area Atmospheric and Liquid Radioactive Releases

Atmospheric

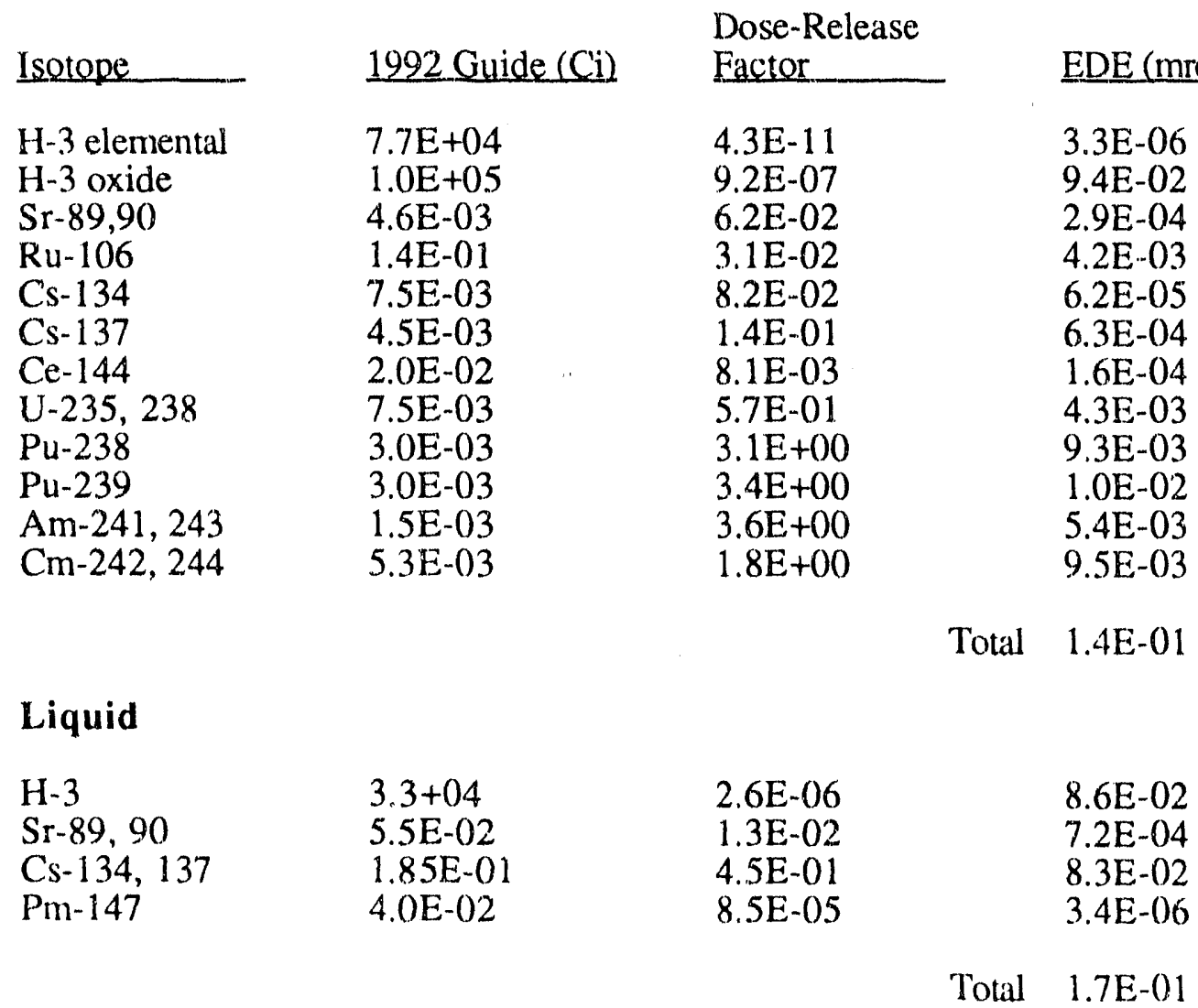


Table VI-2. ALARA Guides for F-Area Atmospheric and Liquid Radioactive Releases

Atmospheric

\begin{tabular}{|c|c|c|c|}
\hline Isotope & 1992 Guide (Ci) & $\begin{array}{l}\text { Dose-Release } \\
\text { Factor }\end{array}$ & EDE (mrem) \\
\hline Sr 89,90 & $1.4 \mathrm{E}-03$ & 6.2E-()2 & $8.7 E-05$ \\
\hline$R u-106$ & $1.5 \mathrm{E}-02$ & $3.1 \mathrm{E}-(02$ & $4.7 \mathrm{E}-04$ \\
\hline Cs- 137 & $1.5 \mathrm{E}-03$ & $1.4 \mathrm{E}-01$ & $2.1 E-(04$ \\
\hline$U-235,238$ & $2.5 \mathrm{E}-03$ & $5.7 \mathrm{E}-01$ & $1.4 \mathrm{E}-() 3$ \\
\hline Pu-238 & $3.0 \mathrm{E}-03$ & $3.1 \mathrm{E}+00$ & $9.3 \mathrm{E}-03$ \\
\hline $\mathrm{Pu}-239$ & $3.0 \mathrm{E}-03$ & $3.4 \mathrm{E}+(0)$ & $1.0 \mathrm{E}-(02$ \\
\hline Am-241, 243 & $4.5 \mathrm{E}-03$ & $3.6 \mathrm{E}+00$ & $1.6 \mathrm{E}-() 2$ \\
\hline $\mathrm{Cm}-242,244$ & 7.0E-(04 & $1.8 \mathrm{E}+00$ & $1.3 \mathrm{E}-03$ \\
\hline & & & $3.9 \mathrm{E}-02$ \\
\hline
\end{tabular}

\section{Liquid}

\section{$\mathrm{H}-3$}

Sr-89, 90

Cs- 134,137

$\mathrm{Pm}-147$

Pu-239
$7.7 \mathrm{E}+01$

2.0E-02

$5.0 \mathrm{E}-02$

$4.5 \mathrm{E}-02$

$1.8 \mathrm{E}-02$
2.6E-06

$1.3 \mathrm{E}-02$

$4.5 \mathrm{E}-01$

8.5E-05

2.0E-01
2.0E-04

$2.6 \mathrm{E}-04$

2.3E-02

$3.8 \mathrm{E}-06$

3. $6 \mathrm{E}-03$

Total $2.7 \mathrm{E}-() 2$ 


\section{Savannah River Site Interim Waste Management \\ Program Plan--FY 1991-1992}

\section{Environmental and Monitoring Programs May 1992}

As new information concerning the fate of specific radionuclides in the environment became available, release standards were revised; and in 1963, there was a new administrative policy at SRS which was to define radiation protection guides in terms of dose for the offsite population. This Standard was based on recommendations by the Federal Radiation Council. The 1963 Technical Standard also included plant relearse guides. With the exception of ${ }^{131} \mathrm{I}$, the release guides pertained only to liquid releases.

In 1971, the concept of reducing public ex posure in the vicinity of SRS as low as practicable was incorporated in the revised Technical Standard. Therefore, the 1972 Standard not only reflected federal guidelines and operating experience but specified an offplant limit more closely reflecting plant capability.

One important difference between 1963 and 1972 Standards was that 1963 limits applied to offplant population groups, and the 1972 annual exposure limits then and now apply to the maximum dose received by an offplant individual. Operating release guides developed for 1972 also included 28 atmospheric release guides along with the liquid release guides.

Tritium releases to streams include direct releases and migration from recently closed seepage basins and the SWDF. While direct releases of tritium to streams have decreased, migration from recently closed seepage basins and the SWDF has resulted in an overall decrease to the river.

\subsection{Tritium Control Processes}

Tritium is the most significant radioisotope emitted from SRS Operations in terms of offsite dose. Tritium is released from several SRS operations to the environment. Liquid releases of tritium to the plant streams and the Savannah River iriclude both direct releases as well as tritiated groundwater migrating from basins.

In 1990, the calculated maximum individual doses from all SRS atmospheric releases of all radionuclides was 0.16; for drinking water, 0.08; and for fish consumption, 0.12. EPA limits for atmospheric doses is 10 mrem; drinking water dose is 4 mrem. Monitoring shows that the dose concentration lessens as distance from the site grows.

In 1990, atmospheric tritium accounted for approximately 87 percent of the site perimeter dose from atmospheric releases. It is the only radionuclide of SRS origin which is detected routinely in offsite air. The average concentration of tritium oxide, calculated and verified by measurements at the plant perimeter monitoring stations for 1990, was $32 \mathrm{pCi}$ per cubic meter of air.

Tritium constitutes the major release of radioactive material to liquid effluents and is the radionuclide having the highest offsite concentration. Although tritium accounts for only 21 percent of SRS liquid releases at the site boundary, it is the greatest contributor to total dose ( 90 percent) for actual downstream consumers of water. Radiocesium and other isotopes which dominate the liquid dose at the site boundary are deposited in sediments of the river or are removed by conventional water treatment practices prior to reaching actual consumers. The maximum 1990 individual dose commitment for maximum water consumption at Beaufort-Jasper SC and Fort Wentworth, GA was 0.08 mrem. When compared with the EPA standard for public water supplies of $4 \mathrm{mrem}$, this dose is 3.0 percent of the EPA standard. Clearly, the actual doses from tritium to downstream consumers of water from the Savannah River are very low. 
In the past, several studies have been done and programs implemented to address tritium releases. DOE-SR and WSRC have recognized that further reduction in tritium releases would be costly and probably not justified on the basis of the very small dose commitments currently in effect and of the small incremental reductions realized. For example, in 1989, management concluded that the large costs of $\$ 10-20 \mathrm{MM}$ for mitigating aqueous tritium discharged through the $\mathrm{F} / \mathrm{l} 1$ ETF were not justified.

To improve detection levels of atmospheric tritium, 12 site perimeter stations were added to the existing monitoring network. These stations will supplement the site's emergency response capability by continuously measuring and periodically reporting gamma radiation levels and tritium concentrations from each 30-degree sector around SRS. The tritium ion chambers can detect tritium concentrations from $1 \times 10^{-6} \mathrm{pCi} / \mathrm{m}^{3}$ to $1 \times 10^{-2} \mathrm{pCi} / \mathrm{m}^{3}$.

\section{Tritium Facilities}

Tritium as a site product for SRS is created in the reactors by neutron capture in Lithium-6 in the lithium/aluminum targets and control rods. This capture produces tritium in a concentrated form which is then extracted and packaged for use in the nation's weapons program. Most releases occur to the atmosphere during extraction and packaging operations in the tritium facilities located in $H$ Area. Many measures have been undertaken in the last few years to mitigate or eliminate both routine and accidental releases.

\section{Replacement Tritium Facility}

The Replacement Tritium Facility (RTF), also known as the Tritium-Loading Facility is designed to replace and upgrade some of the processing and loading functions presently conducted in 234-H. Significant reductions of routine and accidental tritium releases to the atmosphere and groundwater will occur when this new facility is completed and operational. Design improvements in containment, tritium recycle system, maintenance techniques, etc, are expected to result in about a 20-fold decrease in atmospheric releases from the current facility. Liquid effluents from RTF will consist of small quantities of uncontaminated process cooling water and any water from fire fighting collected in a hold tank for analysis prior to release. All transfer lines located within the concrete floor or walls of the facility and material will be pumped to existing tritium facilities headers for disposal or transfer. The facility will be constructed underground; its floor will be sealed to prevent any transfer of fluids out or groundwater into the facility.

\section{Beplacement Purification Facility}

The Replacement Purification Facility is a line item project for FY95. It will replace some of the purification operations currently done in 232-H. There will be no oil- and mercury-containing pumps, resulting in the reduction of mixed wastes from contaminated oil and mercury. The facility will be designed for a 10 - to 20 -fold decrease in atmospheric releases of tritium as compared to the existing facility. 


\section{Sterage of Tritiated Oil in Steel Containers}

Atmospheric tritium releases were reduced when the method for storing tritiated oil was modified from plastic containers to stainless steel containers. Tritium permeated through the plastic and outgassed to the atmosphere. Permeation of tritium through steel containers has not been detected. Losses to the atmosphere were reduced by about $50 \mathrm{kCi} / \mathrm{yr}$.

\section{Improved Line Break Procedures}

Accidental tritium releases occur during process maintenance work involving line breaks. Improved pressure measurement devices to detect the presence of tritium oxide and reduce the incidence of accidental atmospheric releases have been implemented. Procedural improvements in the verification of process lines during line break operations have been implemented. The estimated reduction of tritium releases to the atmosphere using the improved line break procedures is about $50 \mathrm{kCi} / \mathrm{yr}$.

\section{Extraction of Tritium from Furnaces Directly into Tanks}

Tritium containing gases, evolved from the furnace extraction operation of lithium/aluminum targets and control rods, are pumped through a palladium diffuser to separate the hydrogens from helium and other gasses. Flow rate through the diffuser was a limiting factor that caused pressure to build up in the furnaces during extractions. The pressure caused increased permeation of tritium into the furnaces and crucible walls, resulting in higher tritium releases when the furnaces were opened to the atmosphere. Changing this process to one of extraction directly into tanks prior to the diffusion allows the extraction pumps to operate at full capacity and maintain low pressure in the furnaces. Pressure buildup of tritium in the furnaces is eliminated. This process change has been implemented and resulted in the reduction of routine tritium releases to the atmosphere from this source by approximately 70 percent.

\section{Release Controls for Solid Waste}

The primary tritiated solid wastes are the waste crucibles from the tritium extraction process, other process vessels and job control waste containing tritium. The waste crucibles are steel cylinders, containing lithium/aluminum alloy and residual tritium, both of which were disposed of in the low-level Solid Waste Facility where they became one of the main sources of tritium contamination of groundwater at this facility. Control efforts in effect include the sealing of the open end of the crucible with an epoxy type plug to prevent reaction with, and extraction by, soil moisture after trench burial. Further improvements to this disposal have ben made such as "greater confinement disposal" to reduce or eliminate contact with groundwater. The concept of greater confinement has been expanded to include most other sources of confinement of the wide range of tritiated solid wastes, the planned solution is to construct above-grade concrete vaults in which natural decay of tritium may occur without contamination of groundwaters. This concept is based on decoupling the migration pathway for tritium to groundwater. Vault storage provides a barrier and decay time constraints to eliminate this source of release. 


\section{Reactor Facilities}

Tritium is also produced in the SRS reactor moderator by activation of deuterium. This tritium concentration builds up slowly year by year in the moderator. Some of this tritium is lost to the atmosphere and to liquid effluents by evaporation of moderator leaks and carry over of tritium oxide on fuel and target elements during reactor discharge. A tmospheric releases of tritium from each reactor can be as high as $60 \mathrm{kCi} / \mathrm{yr}$, as a function of the tritium concentration in the moderator. All gaseous radioactive releases through the K-Area stacks are monitored continuously. DOE investigates every above-normal activity level to locate the source and correct the condition.

Direct releases to plant streams and the Savannah River from the reactor areas have ranged from 2700 to $7000 \mathrm{Ci} / \mathrm{yr}$ since 1984 . The source of the direct releases is moderator leaks to the cooling water in the reactor heat exchangers and discharges to the process sewers. Target and spent fuel assemblies are rinsed with light water in the discharge machine as soon as irradiated assemblies have been withdrawn fully from the reactor vessel. This rinsing serves two purposes: 1) it allows heavy water to be reclaimed from the discharged (ssemblies, and 2) it minimizes the carry over of tritiated heavy water to the disassembly basin. The rinse water is collected by the discharge machine water pan and sent to a 2,27,0-liter rinse collection tank. Subsequently, the rinse water is placed in drums and reworked to remove the light water from the heavy water moderator. The disassembly basin has water-circulating systems to control radioactivity, chemistry, clarity, and temperature. Sections of the basin can be isolated to aid in controlling the temperature or the spread of radioactive contamination. Periodic purging of the disassembly basin water is necessary to reduce the radiation exposure to operating personnel from the accumulation of radioactive contaminants, particularly tritium. The water from seepage basins enters shallow aquifers where tritium undergoes radioactive decay as it migrates to outcrops at onsite surface streams. Transport and flow modeling results have shown that migration from the K-Area basin to Indian Grave Branch takes as long as six years.

DOE has made the decision that $\mathrm{K}$ Reactor will operate at a 30-percent power level. Operating at this level will decrease the frequency of tritium releases resulting from moderator evaporation during charge and discharge operations. The rate of accumulation of tritium in the disassembly basins and seepage basins would also be lessened.

\section{Moderator Detritiation Plant}

A moderator detritiation plant has been scoped as part of the New Production Reactor (NPR). If SRS is selected for the NPR, the plant will reduce moderator tritium concentration over a period of years and will result in eventual reduction in the tritium dose from reactor releases to atmosphere and water by a factor of 10 , thereby reducing total SRS offsite exposures and onsite exposures in the Reactor Restart Division. Reducing the tritium content of the moderator will reduce the tritium in several waste streams including: 1) the reactor atmospheric and liquid releases, 2) the liquid releases in the 2(0)-F Area associated with the reactor area waste water processed in the General Purpose Evaporators, and 3) the atmospheric and liquid releases from the 400-D Rework Facility. 


\section{0-D Rework Facility}

The 4(K)-D Area Moderator Rework Facility exists to recover tritiated moderator from degraded heavy water. Light water is eliminated from the degraded moderator by vacuum fractional distillation. Releases of tritium to Beaver Dam Creek from the 400-D operation have ranged from about 1400 to $3300 \mathrm{Ci} / \mathrm{yr}$ since 1984 . Atmospheric releases of tritium from routine 400 -D operation were only 329 Curies in 1988 and have the potential of being in the range of only $2500 \mathrm{Ci} / \mathrm{yr}$.

\section{Sealless Pumps}

The need to replace all pumps in the 400-Area Rework Facility with new sealless pumps will be re-evaluated during 1992. This project was proposed and tested to reduce tritium releases to the atmosphere.

\section{Basins and Tritiated Groundwater Outcroppings}

Outcroppings from the 100-K and 100-P Reactor Area seepage basin to Steel Creek and Indian Grave Branch, respectively, have ranged from 3700 to $7500 \mathrm{Ci} / \mathrm{yr}$ from 1984-1987. Furthermore, some unknown fraction of the tritium that outcrops into Four Mile Creek originates in the Solid Waste Facility and is due to the past practices for disposal of tritium-bearing solid wastes. Installation of hydraulic barriers to mitigate these outcroppings would be much more expensive than the estimate for such barriers at the F/H Seepage Basins. This issue will have to be researched further.

SRL has been studying treatment alternatives for disassembly basin purge waters from the SRS Reactor areas. These purges are necessary to maintain the level of tritium in the basins low enough for personnel working at these facilities.

\subsection{Monitoring Programs for ETF Effluent}

SRS self-monitors the treated effluent stream from the F/H Effluent Treatment Facility to NPDES outfall H-()16 for:

- Radionuclides

To ensure compliance with the guides on "F/H releases to streams", WMO operates a flowproportional sampler at the outfall. Environmental Monitoring Section analyzes the sample daily and reports the releases and cumulative totals.

- NPDES Parameters

To comply with the NPDES permit, WMO operates a continuous $\mathrm{pH}$ meter and a flowproportional composite sampler at the outfall. Environmental Monitoring Section takes additional grab measurements and has the composite samples analyzed offsite (weekly or monthly as specified in the permit), "The results are reported to EPD/DOE/DHEC. 
Before each batch of treated effluent is discharged, the Laboratory Department analyzes a grab sample of the batch for indicator compounds.

- Toxicity

To ensure that there is no long-term toxicity, or bioaccumulation of mercury, in Upper Three Runs Creek as a result of the ETF discharge, and to comply with a special condition in the NPDES permit, WMT and SRL (ESD) administer a contract whereby an offsite laboratory conducts water chemistry analyses and both instream population counting and laboratory testing. 
-

BLANK 


\section{RFLATED SUBJECTS}




\section{RELATED SUBJECTS}

\section{A. DEFENSE WASTE PROCESSING FACILITY (DWPF)}

All HLW at SRS will eventually be processed at the DWPF to produce a waste form suitable for permanent disposal.

The product of the DWPF melting operation will be a borosilicate glass containing nominally $28 \mathrm{wt} \%$ oxides. The glass will be contained in stainless steel canisters about $60 \mathrm{~cm}$ in diameter by $3(1) \mathrm{cm}$ in length. In preparation for solidification to glass, insoluble sludges containing most of the Sr-90 and long-lived actinides in the SRS wastes will be treated with sodium hydroxide to reduce the aluminum hydroxide content, washed with water to reduce the quantity of soluble chemicals, then transferred to the DWPF via a jacketed pipeline. In the DWPF, formic acid will be added to improve pumping properties, prevent solids formation in the melter, and reduce melter foaming; mercury will be separated by distillation; and the sludge, mixed with a borosilicate glass frit, will be fed as slurry to the DWPF melter. If SRS reactor operation continues to the year 200), about 15 million liters ( 4 million gallons) of HLW sludge will be processed to glass form within about 20 years of DWPF startup. The proposed hot startup of DWPF is scheduled for 1994. The DWPF will initially produce 300 to 400 glass waste canisters per year.

Soluble salt components of the HLW will be processed via the ITP process. ITP separates the soluble HLW into a decontaminated solution stream and a precipitate stream, which contains the majority of the radionuclides. The precipitated solids will be concentrated by filtration and accumulated in a tank, then transferred as slurry to the DWPF. In the DWPF, they will be treated to decompose the organic salt and fed along with sludge components of the wastes to the glass melter. A formic acid hydrolysis process has been developed to decompose the TPB precipitate and remove aromatic hydrocarbons (benzene) from the radioactive solids before the material is charged to the melter. The decontaminated salt solution from the ITP process will be converted to a solid form (termed "saltstone") by mixing with a blended cement for onsite disposal as LLW. About 105 million gallons of salt solution must the processed to work off SRS waste inventories, which is expected by the year 2000 .

After they are filled with glass, the DWPF canisters will be stored in an onsite vault pending availability of a federal repository for permanent waste disposal. The storage vault constructed as part of the DWPF project will provide sufficient capacity to contain the production of about five years. Additional storage capacity will be provided later to contain projected DWPF output until the repository begins accepting SRS canisters, currently scheduled for 2008 . Following interim storage, the canisters in special casks will be shipped by truck or rail to the repository site. At the repository, the canisters will be packaged in appropriate containers and emplaced for permanent disposal in the underground facilities. In a representative case, the DWPF canisters would be buried in tuff or geologic formations in conjunction with commercial nuclear wastes, using a repository design specially augmented to accommodate the defense waste. 


\section{B. WASTE MANAGEMENT PERSONNEL TRAINING}

Training in Waste Management has been an ongoing activity since the department formed. At first, most training consisted of informal on-the-job training, primarily conducted by experienced peers. During the latter 1980 s, Waste Management realized that a more formal type of facilityspecific training was needed. In 1986, management decided to increase the training effort by appointing a separate training group.

The Waste Management Training Group is currently charged with developing and delivering the training necessary to enable employees to accomplish their job responsibilities in a safe and environmentally sound manner. The program is divided into the following areas:

Operator Training

Mechanic Training

Supervisory Training

Technical Staff Training

Management Training

\section{Operator Training}

In 1989, it was recognized that the average operator experience level had declined from approximately 15 years in the mid-1980s to less than two years. Also, a 50-percent increase in the operator staff was planned for 1990. This increase was necessary to augment shift staffing to provide process relief (for training) and to staff new facilities, as well as restarts of existing facilities. Based on this, on-the-job training, by a fellow operator coupled with a limited amount of classroom training, was no longer a feasible means of imparting the knowledge and skills necessary for operation of waste management facilities.

In addition, several new requirements for training were adopted:

- DOE Order 5480.18 (Accreditation of Training Programs)

- Performance Improvement Plan (INPO Guidelines/DOE Order 5480.19)

- DOE Order 5480.20 (Personnel Selection, Qualification, Training, and Staffing)

As a result, many actions have recently been taken to upgrade the operator training program. First, an Initial Self Evaluation was completed vs. the DOE Accreditation Order, 5480.18. Second, the operator training staff was increased from 4 to 24 full time employees. Seven of the new trainers were designated as on - the-job trainers (OJ'T), the remainder as classroom instructors/ developers. These trainers are primarily personnel with waste management process knowledge who are qualified as trainers through formal instruction by Interim Waste Programs (IWP).

Finally, a WMO Operator Training Policy was developed and published. This formalized the method of using the OJT instructors and describes how training will be conducted until a full performance-based training system required by DOE Order 5480.18 is in place. This training policy is described below:

- Upon assignment to IWP, a trainee will be assigned to temporary days until he/she can complete initial training. Initial training includes: WMO General course (10 courses), Radiation Worker Training, and RCRA indoctrination. The initial WMO classroom instruction is given 
in the WM training facility (705-H). Upon successful completion of this initial training, he/she will be permanently assigned to a WMO facility through a job canvas.

- After reporting to the assigned facility, the trainee must first complete Facility General Training. Existing classroom lesson plans for Facility General Training courses are under review and will be integrated into Facility General as they are completed. Until the revision of these lesson plans is complete, trainees will be provided some additional overview and description of the process. To assist in this and future facility-specific training, an OJT trainer will be assigned to teach the trainee the core procedures as listed in the WMO Operator Training Policy.

- After successful completion of the Facility General Training, the facility manager will specify facility-specific qualification areas on which the trainee is to be qualified. Of 26 required qualification area classroom lesson plans, 14 have been defined, developed, and implemented.

- The next phase of the qualification process is OJT on-the-core procedures listed for the facilityspecific qualification areas assigned by the facility manager. OJT will consist of a discussion of and hands on training of each of the core procedures. Formal OJT Guides have been developed for 37 of the current requirement of 44 . The training must be conducted by a certified OJT trainer. OJT trainer certification may be obtained by completing the IWP-OJ'T Train-The-Trainer Course.

- Upon completion of OJT, an evaluation will be conducted by an independent evaluator to determine if the trainee has acquired the required knowledge and skills. The independent evaluator may not be the OJT trainer who provided the training nor the trainee's first-line supervisor. The independent evaluator and facility management will then sign the Training and Qualification Record, indicating that they are satisfied that the trainee can satisfactorily perform the tasks associated with the qualification area without direct supervision.

- The Training and Qualification Record will then be forwarded to the IWP operator training manager for inclusion in the permanent employee training records. The training manager will ensure that the qualification area summary used for assignment of o vertime is updated. Only qualified operators may be offered overtime to perform unsupervised work in a qualification area. The only exception is that while under direct supervision a nonqualified operator may be permitted to work overtime performing nonskilled work such as housekeeping.

- An operator is initially trained only on qualification of area core procedures (those listed in the training policy). When a noncore procedure must be performed, the supervisor/manager will notify the OJT trainer who, prior to its use, will train the operator on that noncore procedure. The training will be conducted as specified above for core procedures. During emergencies or time sensitive situations, the operator may be trained on that procedure by performing it under direct supervision.

- Training on noncore procedures (whether by OJT trainers or via performing the job under direct supervision) will be documented on a matrix for the facility which lists all procedures for that facility (based on the procedure index). The OJT trainers will provide and maintain a facility-specific matrix for each operator. These records will be maintained in the field files so that they can be referred to as needed.

- This waste nlanagement training is in addition to a production basic training course given by the Personnel Department to all operators before they come to IWP. 


\section{Mechanical Training}

During 1988, it was recognized that the average mechanic experience level was declining drastically. Forty percent of the mechanics had less than one year of experience and only ten percent had more than four years experience. Also, at this same time, the number of maintenance personnel was projected to increase by 150 percent over the next two years to provide service for new facilities and equipment.

New IWP mechanics were receiving 16-20 weeks of basic training (E\&I or Maintenance) and approximately ten weeks of advanced general training. However, no formal training was available on waste management specific equipment and systems. This was a particular concern because of the complexity of the new facilities and equipment due to technological advancements.

Several steps were taken to address this situation. First, a needs assessment was conducted, which resulted in a list of facility-specific courses to be developed. Second, a mechanic training group was formed to develop and deliver these facility-specific courses. These courses have now been developed and consist of both classroom training and hands-on training (where training aids are available) or simulation. A formal evaluation, via written exams and performance evaluations, follows the training.

More recently, an Initial Self Evaluation was completed vs. the DOE Accreditation Order, 5480.18. A formal job and task analysis is currently under way which should provide the data necessary for development of a more comprehensive program.

\section{Supervisory Training}

This training program is currently identical to the operator or mechanic program for operations and works engineering first-line supervisors. This program will be expanded to cover management skills, etc., as development of the overall training program progresses.

\section{Technical Staff Training}

This program currently consists of the following:

Professionalism Training

Waste Management Technical Orientation Program (classroom and tours)

New Waste Management Employee Handbook

A needs assessment has been completed, and development of course ware has begun.

\section{QUALITY ASSURANCE PROGRAM}

The Westinghouse Savannah River Company Quality Assurance Manual (WSRC-1Q) was issued in $4 / 1 / 9()$. This manual provides a description of the requirements, responsibilities, and controls necessary for systematic implementation of the Quality Assurance program requirements 
specified in DOE Order 5700.6B and the WSRC QA Program requirements document, WSRC-1(05, SRS Quality Assurance Plan.

The Interim Waste Management Program Management Team (PMT) developed specific WM PMT Quality Implementing Procedures to implement the Quality Assurance Program requirements contained in DOE Order 570).6B and the WSRC-1Q Manual. The Quality Implementing Procedures are contained in the Waste Management Program Management Team Administrative Manual (SW6).

In October 1991, a review of the Quality Assurance Program implementation was performed. The review used WSRC-RP-723, Implementation Requirements for 1Q, WSRC Quality Assurance Manual Procedures, September 1991 and resulted in the conclusion that the WM-PMT was in compliance with these requirements, except for development of forward fit and back fit schedules. These schedules were developed and issued in January 1992. Therefore, the Waste Management Quality Assurance Program is implemented based on the requirements document WSRC-RP-723, September 1991.

The PMT issues monthly and quarterly Quality Assurance Program Status Reports.

The WM PMT has developed an implementation plan for the new DOE Order 57(00.6C. The implementation of DOE Order $570(0.6 \mathrm{C}$ will take several years to complete.

\section{RADIOACTIVE WASTE DOCUMENTATION SYSTEM}

WSRC has prepared, and is circulating for approval, a document entitled WSRC Administrative and Procedural Controls System for SRS Reactor and Non-Reactor Nuclear Facilities, Procedural Manual 110. Administrative and procedural controls for Savannah River Site (SRS) safety control documents not addressed by other company level manuals are prescribed in this manual. These documents ensure that basic and important decisions are made after review throughout appropriate elements of the organization and that decisions which could significantly affect nuclear and chemical process safety are reviewed by a technical and safety oversight organization other than the one charged with direct responsibility for the operation.

\section{E. DISCUSSION OF BYPRODUCT RULING}

In 1987. DOE Headquarters published an interpretation of the "Byproduct Rule" in the Federal Register that subjected all DOE radioactive waste which also contains chemically hazardous components (also called "mixed waste") to the EPA and the state regulations under the RCRA. Under the interpretation, DOE continues to regulate the radioactive portion of the waste under the Atomic Energy Act, but EPA (or SCDHEC) regulates any hazardous components under RCRA. The high-level radioactive waste tanks, TRU waste storage facilities, DWPF, and mixed waste streams such as discarded lead shielding were impacted by this ruling. This interpretation went into effect June 1, 1987. 


\section{F. SRS INCLUSION ON THE NATIONAL PRIORITIES LIST (NPL)}

On December 21, 1989, SRS was included on the National Priorities List (NPL). A site included on the NPL falls under the jurisdiction of the Comprehensive Environmental Response, Compensation, and Liability Act (CERCLA). In accordance with Section 120 of CERCLA, DOE is negotiating a Federal Facilities Agreement (FFA) with the U.S. Environmental Protection Agency (EPA) and the South Carolina Department of Health and Environmental Control (SCDHEC) to coordinate cleanup activities at the SRS into one comprehensive strategy. Public participation requirements will include the establishment of an Administrative Record file that documents the selection of cleanup altematives and provides for review and comment by the public of those alternatives. An SRS Public Involvement Plan (PIP) is being designed to facilitate public involvement in the decision-making process for the permitting, the selection of remedial alternatives, and the closure of waste units. The PIP will address the requirements of CERCLA, RCRA, and the National Environmental Policy Act (NEPA).

\section{G. FACILITY PERMITTING}

The Hazardous Waste Storage Buildings (709-G, 709.4G, and 710-U) and Mixed Waste Storage Building $709.2 \mathrm{G}$ are the only WM facilities to date with an approved RCRA Part B permit. The Part $B$ permits for Building 64.3-29E, 643-4.5E, and waste storage pads 20-22 will be submitted to SCDHEC in 1992.

A closure plan has been submitted to SCDHEC for the TRU pads, and a Part B permit application is being prepared. TRU pads No. 1-5 will be permitted under RCRA Subpart X, Miscellaneous Units, TRU pads No. 6.17 and the Experimental Transuranic Waste Assay Facility/Waste Certification Facility LETWAF/ WCF will be permitted as RCRA treatment, storage, disposal (TSD) facilities. Currently TRU Pads 6-17 and the ETWAF/WCF are RCRA interim status facilities.

The F/H ETF, Tank 5(), Interarea Transfer Line, and Low Point Drain Tank are all operating as wastewater-perminted facilities requiring certified operators.

The F- and H-Area Tank Farms and associated new projects will also be permitted as wastewater facilities. This decision was made after two years of permitting discussions with SCDHEC and EPA. On June 30, 1989, a letter was received from SCDHEC stating that the tank farms should be permitted as wastewater facilities. Interim Waste Management has prepared the "Permit Application for an Industrial Wastewater Treatment Facility for the F-and H-Area HLW Tank Farms and submitted it 10 SCDHED on Ju!y 8, 1991. The permit application and tank assessment reports are currently being reviewed by $S C D H E C$.

Also, the FFA, being negotiated by EPA, SCDHEC, and DOE, will specify requirements for secondary containutent and ieak detection for the tank farms. These requirements will be similar to the RCRA tank stindards specified in 40 CFR 264.

With a few excepriens, lacilities which emit chemicals other than air, steam, carbon dioxide, nitrogen, oxygen (or any physical combination of these substances) require a SCDHEC Air Quality Control Permil. National Emissions Standards for Hazardous Air Pollutants (NESHAP) permits are required for ficilities that emit radionuclides above a prescribed level. The following Waste Management facilities are included in these that require air quality control permits and/or NESHAP 
permits: emergency diesel generators, F/H ETF, In-Tank Precipitation, Consolidated Incineration Facility, Transuranic Waste Facility, and the Replacement High Level Waste Evaporator.

Operation of the SRS Sanitary Landfill is permitted by SCDHEC. The landfill is permitted to receive wastes such as paper, plastic, construction debris, empty cans, and carcasses. It may not receive hazardous waste.

\section{RCRA Facilities}

Part B Permit Approved

Hazardous Waste Storage Building 710-U, 709-G, 709-4G, and Mixed Waste Storage

Building 7(09-2G

Interim Status

Mixed Waste Storage Building 643-29G

F and $\mathrm{H}$ Tank Farms

TRU Pads

Mixed Waste Management Facility 643-28G

EIWAF/WCF

Part B Permit Denied

$\mathrm{F}$ - and $\mathrm{H}$-Area Seepage Basins

\section{Future RCRA Facilities}

Consolidated Incineration Facility

Hazardous Waste/Mixed Waste Disposal Facility

Transuranic Waste Facility

RCRA Vault (Y Area)

Wastewater Facilities (approved permits)

F/H Effluent Treatment Facility and Auxiliary Facilities

Tank 50)

H to Z Interarea Transfer Line and Low-Point Drain Tank

Future Wastewater Facilities

F- and H-Area Tank Farms and associated projects/facilities

\section{Air Quality Control Permits*}

Emergency diesel generators

In-Tank Precipitation

Consolidated Incineration Facility

* Additional future facilities may also require Air Quality and NESHAP permits. 


\section{NESHAP Permits*}

F/HETH

In-Tank Precipitation

Consolidated Incineration Facility

Transuranic Waste Facility

Replacement HLLW Evaporator

\section{H. WASTE MANACEMENT MAINTENANCE FACILITY (299-H)}

The Waste Managenem Mantenance Facility is a facility in $\mathrm{H}$ Area for the decontamination, repair, and modilication of contaminated equipment associated with the Savannah River Site radioactive waste management program. This facility was constructed to:

- Eliminate out-of-door repairs, repuiring temporary windbreaks around waste management equipment. Repairs under these conditions are very time-consuming because of the need to meet rigid envirommental control standards and to minimize radiation exposure to personnel.

- Repair waste management equipment that is too large to fit in other existing repair facilities.

- Provide adecuate facilities for decombminating and repairing the increased amount of recoverable equipment that was forescen to be used in the future. The cost of recovering failed equipment is only about 60 percent of the capitil outlay for new equipment.

The maintenance facility is about 156 feet long by 75 feet wide and is divided into several functional sections (truckwell, shielded cell areas, shop and office area, and cold feed preparation area) as shown in Figure VII-1.

The truckwell continins a $15.10 n$ traveling crane which also traverses the shielded cell area. The shielded cell area is sublivided into separate cells for decontamination, repair, and testing of repaired equipment. The cell also contaims a $15 \mathrm{kon}$ traveling crane. The cold feed preparation area, located at the southeast comer of the building is provided for the preparation of cleaning reagents and other reguired solutions. Compressons, air reservoits, enc, are housed in an adjacen building al the northwest comer of the lintility.

The structure is located east of the 21111 chemical storage area and north of the 294-H sand filter. The sand filter pulls exhatust ali al a vacuum from the maintenance facility. Liguid wastes from decontamination operations ane contaned in a 120)-gallon waste collection tank and transferred to the 241.11 waste lank fam. Comaminated solid waste is collected and transferred to the burial groumel.

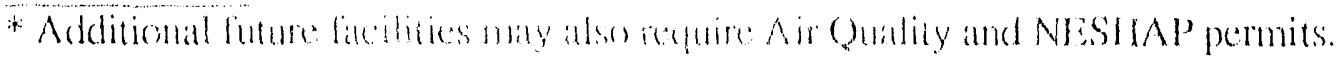




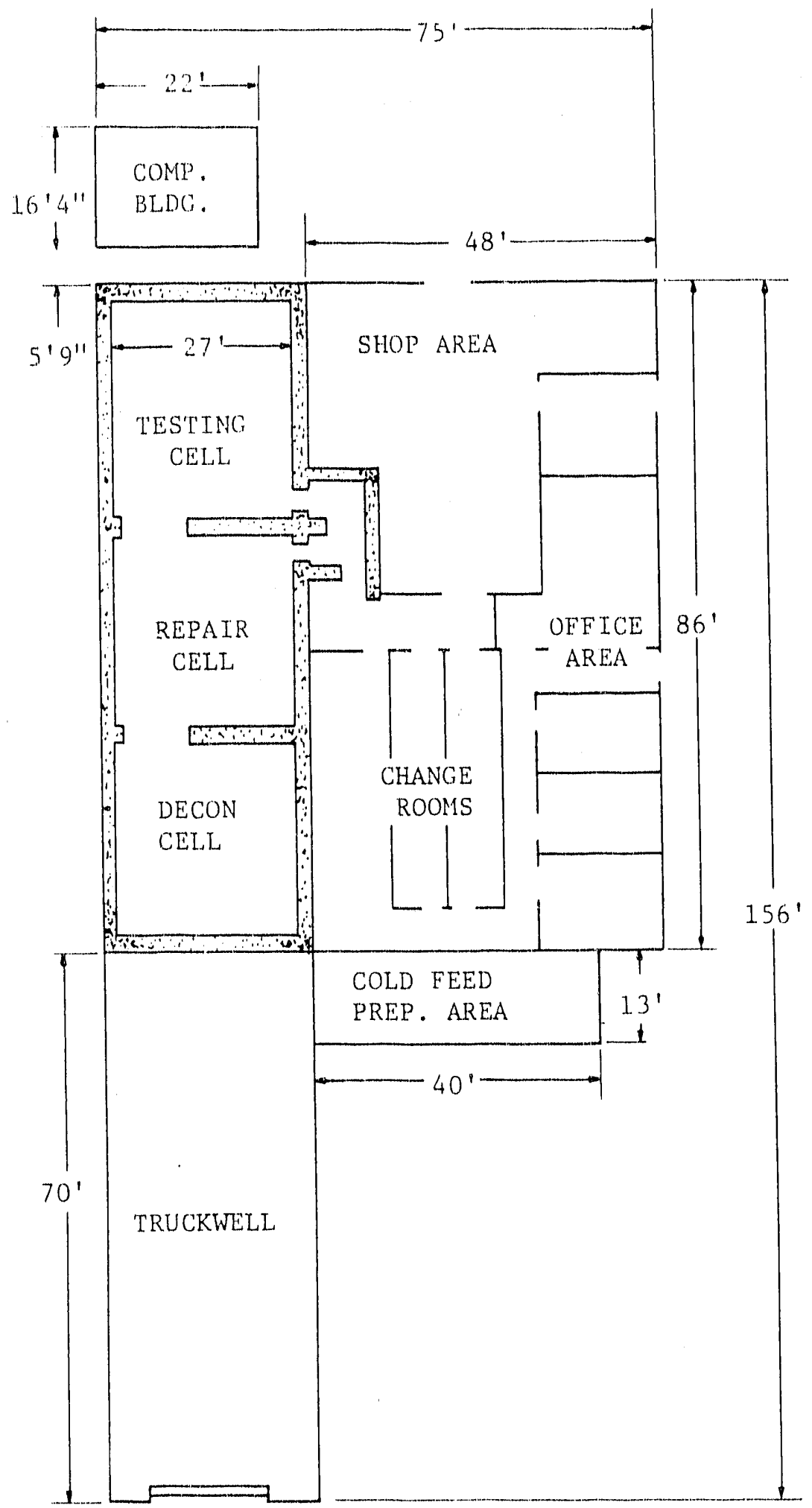

Figure VII-1. Waste Management Maintenance Facility 
BLANK 
VIII. APPENDIXES

APPENDIX I Tank Farm Evaporator

APPENDIX II Cesium Removal Columns

APPENDIX III Tank Construction and Operating History

APPENDIX IV Department of Energy, Savannah River Site 1991 Waste Reduction Report 
-

BLANK 


\section{APPENDIX I}

\section{TANK FARM EVAPORATORS}

The single-stage, bent-tube evaporators were designed for simple maircenance-free operation. The principal features of an evaporator are shown in Figures A.1 and A.r. Wastes containing up to $100 \mathrm{Ci}$ per gallon can be evaporated depending on the shielding av ilable for the particular evalporator. Both gravity and pumped flow are used to transfer hot concentrate between the evaporator and the storage tanks in doubly contained lines up to several hundred feet long.

The evaporators are constructed entirely of stainless steel and operate at atmospheric pressure under alkaline conditions. Each one is steam-heated by a bent-tube bundle designed to facilitate remote descaling. The bowed tubes terminate at both ends in heavy tube sheets maintained at fixed spacing by tie-rods. By periodically surrounding the tubes with relatively cool and dilute waste or water and by heating them intermittently with bursts of steam, alternate thermal expansion and contraction flexes the bowed tubes and aids in spalling and dissolving accumulated scale. An integrally mounted, three-tray, dry bubble-cap column provides de-entrainment of suspended concentrate droplets from the effluent vapor stream. The vapor is condensed in a water-cooled condenser that is vented through a filter to the aimosphere. The $242-\mathrm{F}, 242-16 \mathrm{~F}$, and $242-16 \mathrm{H}$ evaporators have wire mesh separator pads in addition to the bubble caps to improve deentrainment.

Overheads condensate from the evaporator is surveyed continuously for radioactive carryover by a gamma monitor. If the radioactivity level exceeds a preset reading, the condensate is manually diverted to a waste storage tank. Currently, the condensate is pumped through a cesium removal column to reduce the Cs-137 content. This column is a stainless steel vessel containing an ionexchange resin (synthetic zeolite) that gives a decontamination factor for Cs-137 of up to 200 . Effluent from the cesium removal column is alternately passed to one of two stainless steel hold tanks. When the hold tank is full, a sample is analyzed for Cs-137. If the cesium concentration is acceptable, the processed condensate is pumped or drained to the ETF. F-Area cesium concentration is allowed to be higher due to the addition of dilute streams before reaching the ETF. If above the limits, the condensate is returned to a waste tank for reprocessing.

Concentrated bottoms are steam-lifted from the evaporator pot, continuously or intermittently, and they flow by gravity in underground lines directly to nearby waste storage tanks or to a belowgrade concentrate transfer system pump pit for transfer to more remote storage tanks. From the pump pit, the hot concentrate is continuously circulated by the main pump through double-walled pipes, through the upper interior of several wasie tanks in series, and back into the concentrate trinsfer system pump tank. Air-operated drawoff valves, especially designed to minimize stagnant holdup space, are operated intermittently under automatic control to draw a fraction of the circulating stream into a given receiving tank. This recirculation system is used to accommodate relatively low net drawoff rates (original design, $3 \mathrm{gpm}$ ) and still maintain, in practical-size piping $(1-1 / 2$ to 2 inches), sufficient fluid velocity ( $>2 \mathrm{feet} / \mathrm{second})$ to keep the fluid hot and prevent settling of suspended salt narticles. A second pump is provided in the pump tank to permit prompt emplying of the pump tank if the main pump fails. This provision is necessary because salt crystallization would plug the system if the concentrate were allowed to remain stagnant and to cool off. Experience has shown that this spare pump must be run continuously to maintain its operability. During nomal operat: on, its discharge flow goes directly back into the pump tank. 


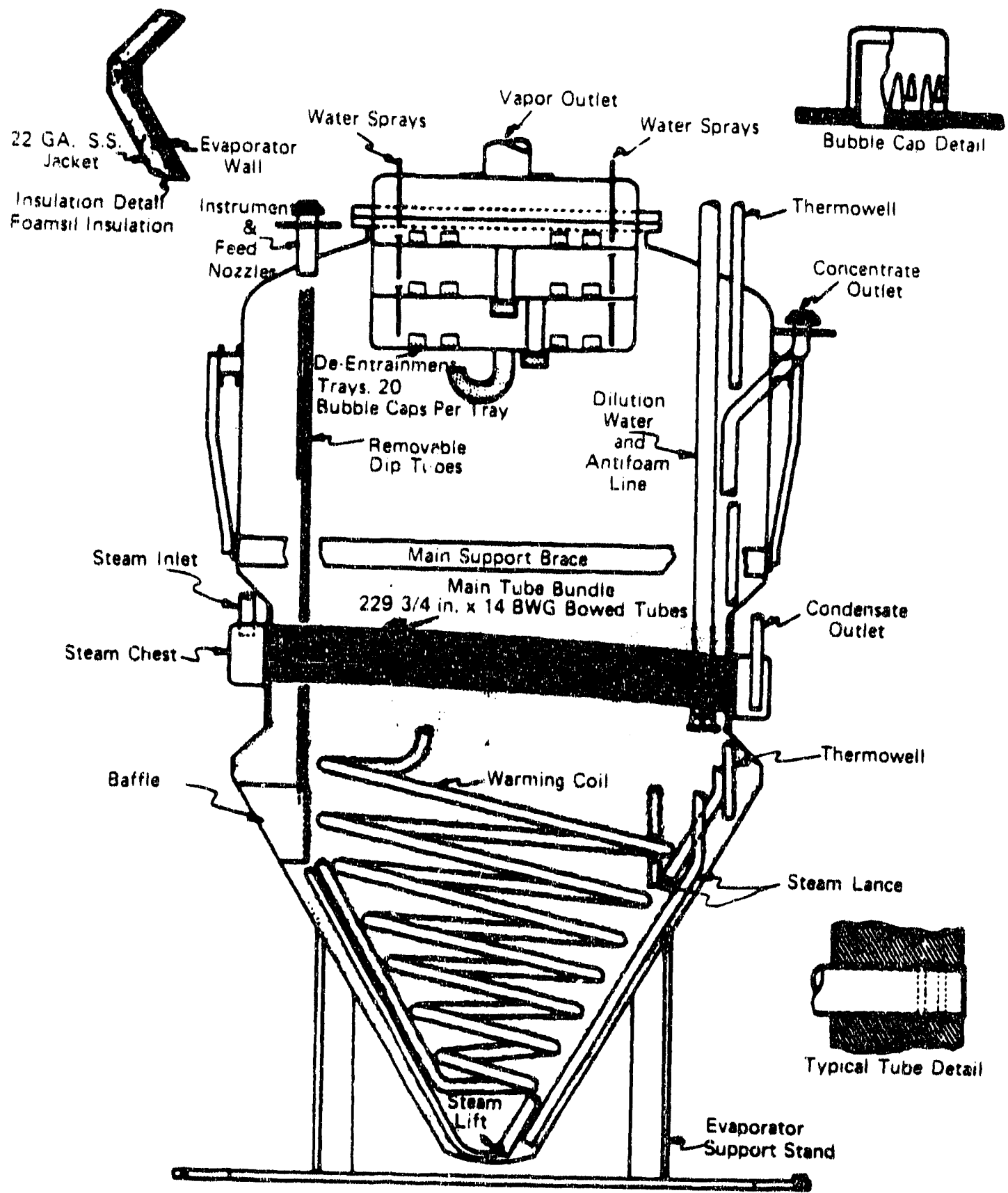

Figure A.1. 242-H Waste Evaporator 


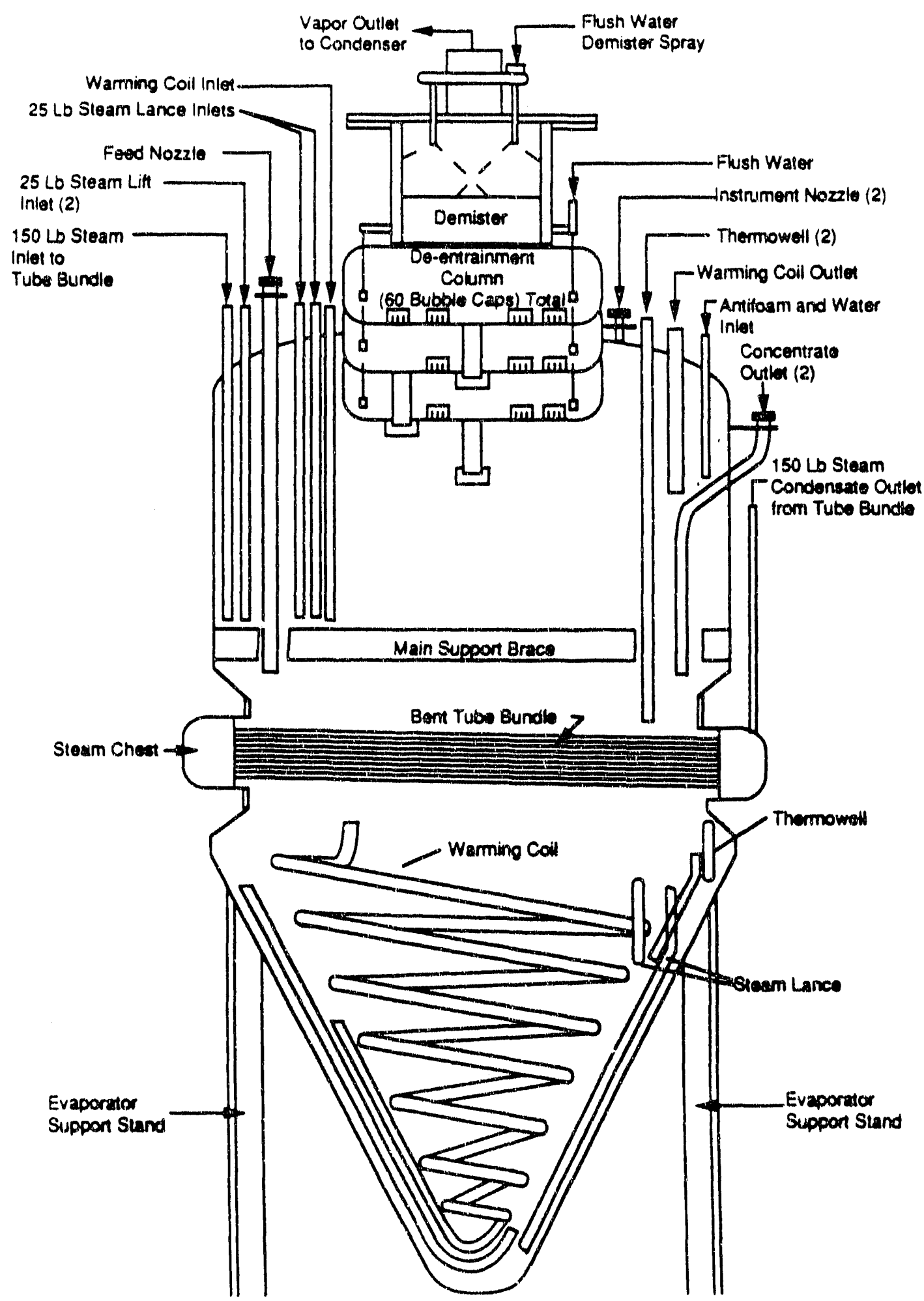

Figure A.2. 242-F, 242-16F, and 242-16H Waste Evaporator 
Concentrated bottoms from the existing pot-type tank farm evaporators must retain enough water to maintain fluidity during transfer through pipes by gravity and/or by the concentrate transfer system to receiving tanks hundreds of feet away.

Projects have been initiated for $242-16 \mathrm{~F}$ and $242-16 \mathrm{H}$ evaporators to upgrade instrumentation and control room functions by providing Distributed Control Systems (DCS's). This project work should be finished by 1992 .

A separate project has also been initiated to provide a new evaporator for reducing the volume of waste generated by the Defense Waste Processing Facility, high-heat waste (HHW), and internal tank farm sources. This will allow retirement of the two original evaporators 1-F and 242$\mathrm{H}$, around 1994. The new evaporator will be similar to the old design, but will have numerous improvements based on new technology or cumulative waste management evaporator experience. These improvements include:

- Doubling the overheads production rate.

- A closed-loop cooling system (instead of once-through well water).

- Gravity draining for concentrate.

- Higher efficiency overheads activity de-entrainment.

- Better containment shielding and ventilation.

- Easier access for work in the cells.

- DCS control.

- Total building enclosure around the evaporator cell to minimize chances of contamination releases during maintenance. 


\section{APPENDIX \|}

\section{CESIUM REMOVAL COLUMNS}

Each cesium removal column is fabricated of stainless steel and holds 10 cubic feet (20) cubic feet for 242-H) of 20-to-50-mesh or 14-to-30-mesh synthetic zeolite (Linde ${ }^{\circledR}$ Molecular Sieve IONDIV IE-95R, Union Carbide Co.). The zeolite (alumina silicate) is supported by a conical, perforated metal screen. Flow is normally downward through the zeolite bed with overall decontamination factors for radiocesium of 10 to 200 .

In F Area and for the $242-16 \mathrm{H}$, where column feed consists only of evaporator overheads, approximately $40(0)$ - to $70(0)$-bed volumes may be processed until unacceptable radiocesium levels are detected in the column effluent. (NOTE: The column effluent is collected in one of two hold tanks and sampled for radiocesium. After an acceptable analysis, the contents of the hold tank are discharged to the ETF. If unacceptable radiocesium concentrations are detected, the contents are recycled.) More often, however, pressure drop across the column becomes excessive before radiocesium breakthrough; either necessitates zeolite replacement. Spent zeolite is discharged directly into the waste tank beneath the column.

In $\mathrm{H}$ Area, aqueous waste from Tank $23 \mathrm{H}$ is blended with the $242-\mathrm{H}$ evaporator condensate as feed to the cesium removal column. Tank $23 \mathrm{H}$ contains waste discharged by the Receiving Basin for Offsite Fuels/Resin Regeneration Facility (RBOF). Experience has shown only 500- to 100() -bed volumes of this feed can be processed before zeolite replacement is necessary. This lower capacity is attributed to the deleterious effect of competing nonradioactive cations and colloidal solids present in the Tank $23 \mathrm{H}$ waste.

Because the biological hazard of radiocesium is much greater than that for most other radioactive elements likely to occur in decontaminated water discharged to the ETF, much tighter limits are placed on Cs-134 and Cs-137 in tank farm evaporator overheads and decontaminated RBOF-RRF wastes. Cs-137 is normally, but not always, the primary radioisotope in these wastes before they are processed through the cesium removal columns (CRC). The CRC removes cesium much more efficiently than it does the other radioisotopes. Because the radiocesium release limit is quite low, the CRC effluent must be analyzed specifically for radiocesium. To expedite analysis of each batch of CRC effluent before release to the ETF, pulse height analyzers (PHAs) are provided in the evaporator control rooms in each area, and they are operated and calibrated by process operators. Composite samples are also accumulated for analysis by the control laboratory.

New PHAs have been installed in the $241-28 \mathrm{H}$ and $241-\mathrm{F}$ Control Rooms. The remaining control room, 241-28F, currently has a new PHA on order, and it will be installed as soon as it is received. The previous PHA's, Tracor-Northern Model TN-170, required frequent recalibration and maintenance, and the printed results gave no information on the sample, operator, or system. The new pulse height analyzers are Canberra Series 20 or S-100 Multichannel analyzers, controlled by an IBM PC. A special order Am-241 doped $2 \times 2$ NaI detector, enclosed in a lead sample holder/shield at the rear of the control room, is connected to a high voltage detector stabilizer system to minimize analysis error. Canberra Gamma-AT analysis software is used to semiautomate the process of collecting sample gamma activity spectrums, subtracting background radiation, comparing the results to a radionuclide library, and printing a detailed report. 
-

BLANK

II-2 


\section{APPENDIX III}

\section{TANK CONSTRUCTION AND OPERATING HISTORY}

\section{Tank Substructures}

Installation of each group of tanks was preceded by drilling exploration to determine the type of earth, load-bearing capacity, presence of cavities, and profile of the water table. Holes were drilled to a depth of at least 150 feet, one at the center of each proposed tank position. In 1951 and 1952, during soil explorations of the sites chosen for Type I tanks, some cavities and soft spots were found and grouted. Soil explorations for subsequent tank installations revealed some deep cavities extensive enough to require grouting.

A 4-inch to 6-inch concrete working slab is first laid completely over the bottom of the multipletank excavation. On that foundation, individual base slabs are constructed for the support of each tank.

The cooled waste tanks (Types I, II, and III) have heavy concrete structures with large columns to support their radiation-shield roofs. When in use, the tanks have sizable thermal stresses in the base slab. Consequently, the tanks are set on reinforced concrete bases with thicknesses varying from 30 inches for Type I to 42 inches for Types II and III. Footings under center columns are as thick as 64 inches.

Because of the domed construction of the roof, the uncooled tanks, Type IV, are of lighter construction and have no roof support columns. They have a 4-inch-thick reinforced concrete base slab with a 3 -inch-thick cement topping and a 13 -inch-thick reinforced concrete perimeter footing to carry the weight of the tank wall, roof, and earth cover.

\section{Type I Tanks}

Type I tanks are the original 12 storage tanks constructed during 1951 to 1953 . Tanks $1 \mathrm{~F}$ through $8 \mathrm{~F}$ are placed in $\mathrm{F}$ Area and Tanks $9 \mathrm{H}$ through $12 \mathrm{H}$ in $\mathrm{H}$ Area. Each primary tank holds 720,000 gallons (nominally 750,000), is 75 feet in diameter and is 24-1/2 feet high. Figure A.3 shows the essential features of Type I tanks, including the primary tank, the secondary pan, and the concrete support structure.

The primary container is a closed cylinder with flat top and bottom constructed from $1 / 2$-inchthick steel plate. The top and bottom are joined to the cylindrical side wall by curved knuckle plates. The primary tank is set in a circular pan of $1 / 2$-inch steel plate, 5 feet deep, and 5 feet larger in diameter than the tank. The secondary vessel, the pan, thus provides an intervening annulus 2.5 feet wide. The assembly of tank and pan is surrounded by a cylindrical reinforced-concrete enclosure with a flat concrete roof and foundation slab. Twelve concrete columns, each 2 feet in diameter with flared capitals and encased in 1/2-inch steel plate, are installed within the primary tank to support the flat concrete roof. The concrete wall and roof are 22 inches thick. 


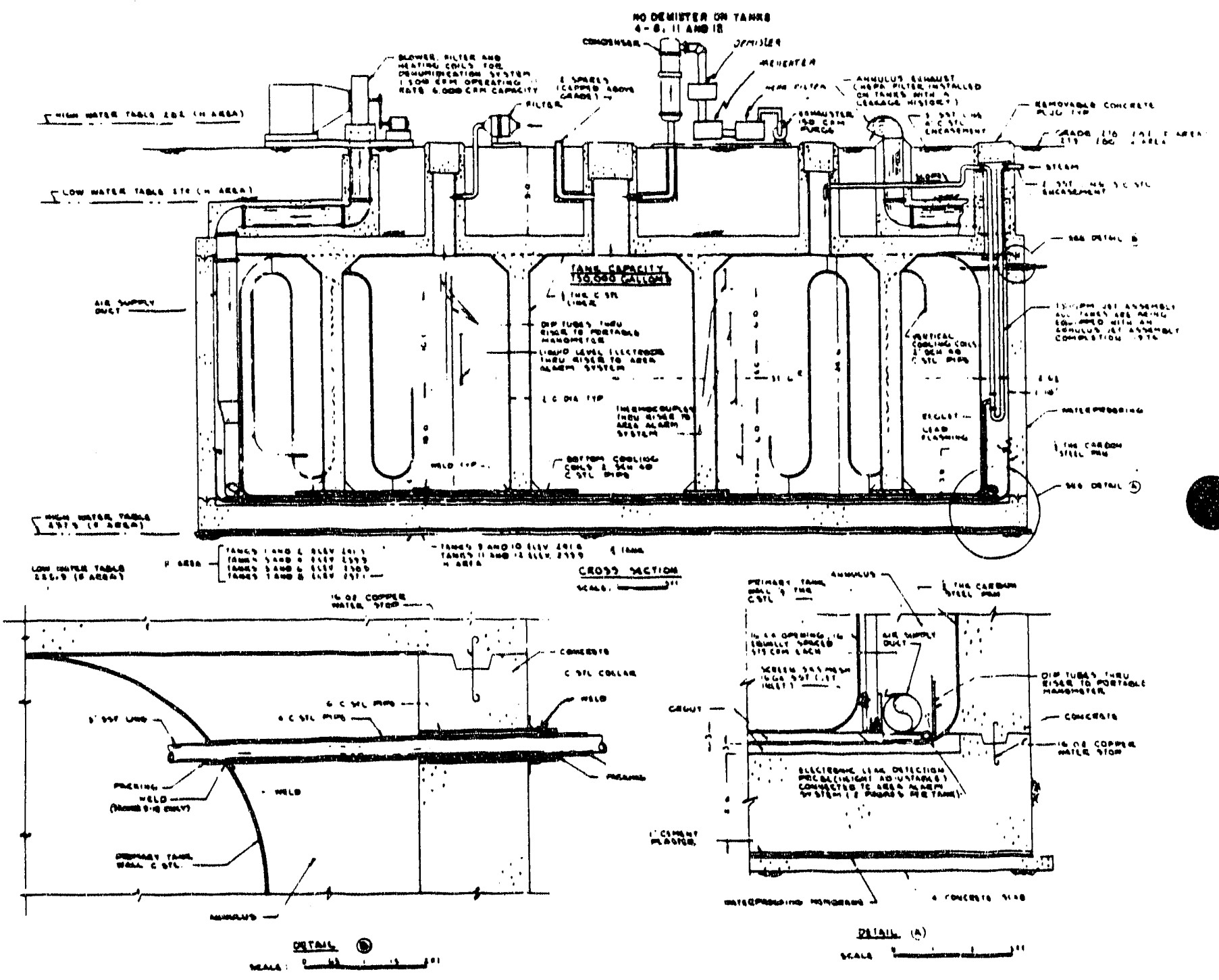

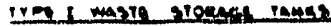

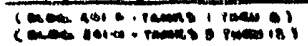

Figure A.3. Type I Waste Tanks 
In F Area, where the water table is relatively low, standard waterproofing was applied to the exterior of the concrete encasement. An additional brick encasement with a poured asphaltic interlayer was used in H Area where the water table sometimes rises above the tank bottoms. A 9. foot layer of earth was placed over the tanks for radiation shielding. Tank cooling is provided by 36 parallel cooling water coils.

All welds in the pal ind primary tank were radiographically inspected, defects were corrected, and the welds were rechecked radiographically. The welds in the flat bottoms of both the pan and the tank were vacuum-tested for leaks. Additionally, both vessels were hydrostatically tested. The water was maintained at full height in the tank for 24 hours before being inspected for leaks. Conling water piping was hydrostatically tested at 300 psig and then leak-tested with 100-psig air pres-sure in the piping.

Several top openings provide access to the tank and annulus; they are fitted with steel-lined reinforced concrete risers through the earth cover to grade level. The risers are stoppered with stepped concrete plugs. Many of the openings are used for instruments installed in the primary tank or in the annulus. A few of the openings are used for tank venting and annulus dehumidification connections. The principal instruments installed in each tank are:

- Liquid Level. Liquid level in the primary tank is measured by a conductivity probe on the end of a graduated tape reeled in or out by a motor drive. A fixed-height probe is used as backup high-level detection. At least two conductivity probes are installed in each annulus to detect the presence of any liquid in the secondary pan. Evidence of leakage into annulus, as well as high liquid level in any of these waste tanks, is signaled to the tank farm control room.

- Temperature. Originally, at least four thermowells, each with multiple thermocouples, were installed in every tank. However, because of the waste removal program some tanks now only have one thermowell with one or more thermocouples. In addition, the primary tank steel wall temperature is measured, and a thermocouple measures tank vent temperature. Temperatures are displayed in the control room. All cooling coils are equipped with thermowells at the outlet end. Active coil thermowells and condenser cooling water outlets are supplied with indicating thermometers.

- Pressure. All cooling coil units are equipped with pressure relief valves at the outlet. The inlet side of both active and spare coil circuits is equipped with a connector for attachment of a pressure gage, if needed. Sensitive pressure gages are installed at several points in the tank ventilation system to detect cessation of flow, filter plugging, etc.

Tank vertilation equipment is installed to provide negative-pressure ventilation of the tank interior. The system consists of a reflux condenser, demister reheater, and HEPA filter, and is connected to a tank top riser opening (designed to accommodate two additional condenser-filter systems, if needed). The reflux condenser is designed to remove one third of the maximum anticipated tank-heat load. If all cooling coils become inoperative, the one installed condenser plus two additional condensers installed in parallel could handle the total heat load; however, operation in this manner would maintain the supernatant liquid waste at the boiling point and is not planned. HEPA filters have been substituted for the fiberglass filters on all Type I tanks. 
Initially, the ventilation load was considered to be tank breathing plus fill displacement. Radiolytic decomposition of water and organic materials in the tanks generates hydrogen, and continuous ventilation in tanks containing HLW must be provided to control the hydrogen concentration below the lower flammability limit (LFL). Changes were made to each tank ventilation system to provide a tank vapor-space purge of about $150 \mathrm{cfm}$ of air.

Dehumidification equipment consisting of a fan, a heater, and ductwork is installed at each tank to keep the annular space dry. Design intent is to maintain annular space atmosphere temperature above the dew point. Filters have been installed on annulus effluent air on all Type I tanks.

Five Type I tanks have leaked detectable amounts of waste into the secondary pans under the primary tanks. None of this waste has escaped from the pans through the concrete vaults into the surrounding ground. Details of their leakage history are presented later in this appendix.

Four Type I tanks, Tanks 9 through 12, are located at low elevations and are susceptible to flooding during severe rains. Three-foot-high concrete dikes have been erected around these tanks to provide additional protection against water inleakage. Each dike has steps which provide access to the tank top. Any water that accumulates inside the dike collects in a sump, is sampled and pumped over the dike, and flows to the storm sewer system.

\section{Type II Tanks}

Tanks $13 \mathrm{H}-16 \mathrm{H}$, constructed in $\mathrm{H}$ Area, 1955 to 1956, are designated Type II tanks (Figure A.4). Each primary tank holds 1,030,(000 gallons, is 85 feet in diameter, and is 27 feet high.

Type II tanks have a single central roof-support column instead of multiple columns. The top and bottom of the steel primary container are jointed to the outer cylinder by curved knuckle plates. The inner cylinder is flared at the top to accommodate the roof-support column. This cylinder is joined to the flat-steel top with a continuous butt weld and to a baseplate fastened to the bottom with a continuous "T" weld. Steel plates used in the construction of the tank are of various thicknesses as follows:

$\begin{array}{ll}\text { Top and bottom } & 1 / 2 \text { inch } \\ \text { Upper knuckle } & 9 / 16 \text { inch } \\ \text { Wall } & 4 / 8 \text { inch } \\ \text { Lower knuckle } & 7 / 8 \text { inch }\end{array}$

The primary tank is set on a l-inch sand bed within a circular pan of half-inch steel plate that is 5 feet deep and 5 feet larger in diameter than the tank. The tank and pan assembly and the surrounding wall are set on a foundation slab 42 inches thick. The roof is supported by the wall and by a central concrete column that fits within the inner cylinder of the vessel. The tanks were placed above the highest expected elevation of the water table, so only standard waterproofing was applied.* Cooling is provided for each Type II tank by 44 parallel cooling water coils. A condenser, filter, and blower are installed in the tank ventilation system.

*The actual water table has been as high as 8 feet above the bottom of the tanks. 
Savannah River Site

Interim Waste Management

Program Plan--FY 1991-1992
Appendix III

Tank Construction and Operating History

May 1992

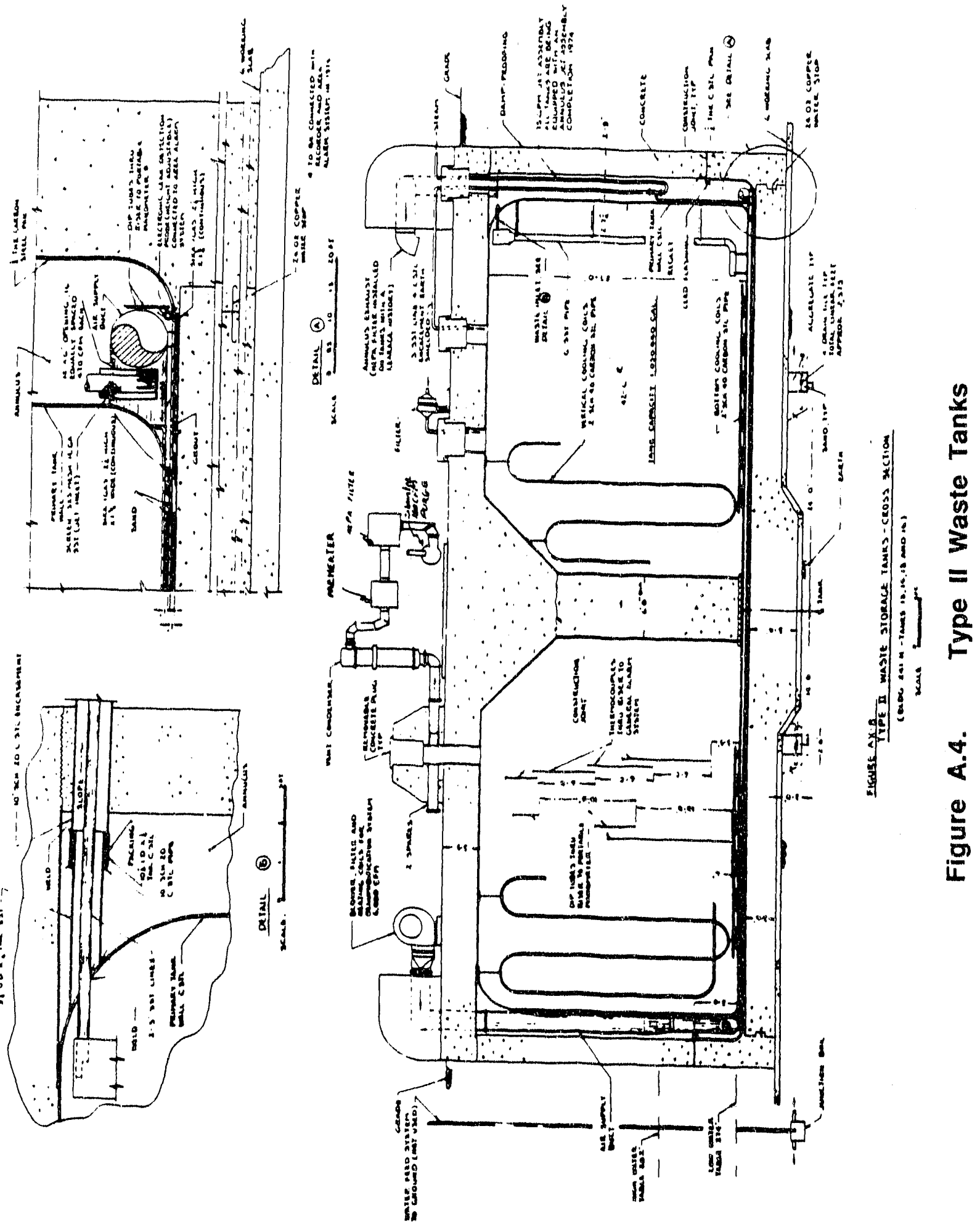


All welds in the primary tanks were radiographically inspected, defects were corrected, and welds were rechecked radiographically. The pans were not inspected radiographically. The welds in the flat bottoms of the pans and the primary tank were vacuum-tested for leaks, and the primary and secondary vessels were hydrostatically tested. Cooling water piping was hydrostatically tested at 300 psi and then leaktested, using soap solution, with 100-psi air pressure in the piping.

The top openings into the tanks and annular spaces are similar to those in the Type I tanks and are used for either instrumentation or for ventilation system connections. Additional annulus access ports (8-inch diameter) have been drilled through the roof of each Type II tank to permit surveillance of most of the primary tank wall. Both the instrumentation and ventilation systems are similar to those of Type I tanks.

All four Type II tanks have developed stress corrosion cracks in the primary vessels, allowing some waste to seep into the secondary pans under the primary tanks. Tank leakage is discussed in detail later in this appendix.

\section{Type III Tanks}

The tanks constructed most recently are designated as Type III (Figure A.5). Twenty-seven Type III tanks have been completed and are in use. Tanks $29 \mathrm{H}$ through $32 \mathrm{H}$ were built in $\mathrm{H}$ Area from 1967 to 1970 . Tanks 33F and 34F were built in F Area from 1969 to 1972 . Tanks $35 \mathrm{H}$ to $37 \mathrm{H}$ were completed and placed in service in $\mathrm{H}$ Area in 1977 . Tanks $25 \mathrm{~F}$ to $28 \mathrm{~F}$ were completed and placed in service in January 1980. Tanks 38 to 51 were completed between 1980-1982.

The Type III tank design was developed after an investigation of leaks from Types I and II primary tanks. At that time (1965) four primary tanks had leaked. Five more have developed leaks since then, so leaks ranging widely in magnitude have now affected five Type I and four Type II tanks. The conclusions of the study were that the primary leak-producing mechanism was stress corrosion cracking at sites in or near the weld seams, and that stress-relieving after fabrication should eliminate the cracking. For the Type III tanks, means were provided for heating each finished steel primary tank to relieve the stresses generated during fabrication. In addition, some stress patterns were avoided or minimized by mounting the roof-supporting column on the foundation pad rather than on the bottom of the primary tank (as in Types I and II) and by providing an annulus clearance around the roof-supporting column. Each primary tank holds 1,300,000 gallons, is 85 feet in diameter, and is 33 feet high. None of the Type III tanks have leaked any waste into the annular spaces nor shown any other evidence of stress corrosion cracking. 
Savannah River Site

Interim Waste Management

Program Plan--FY 1991-1992

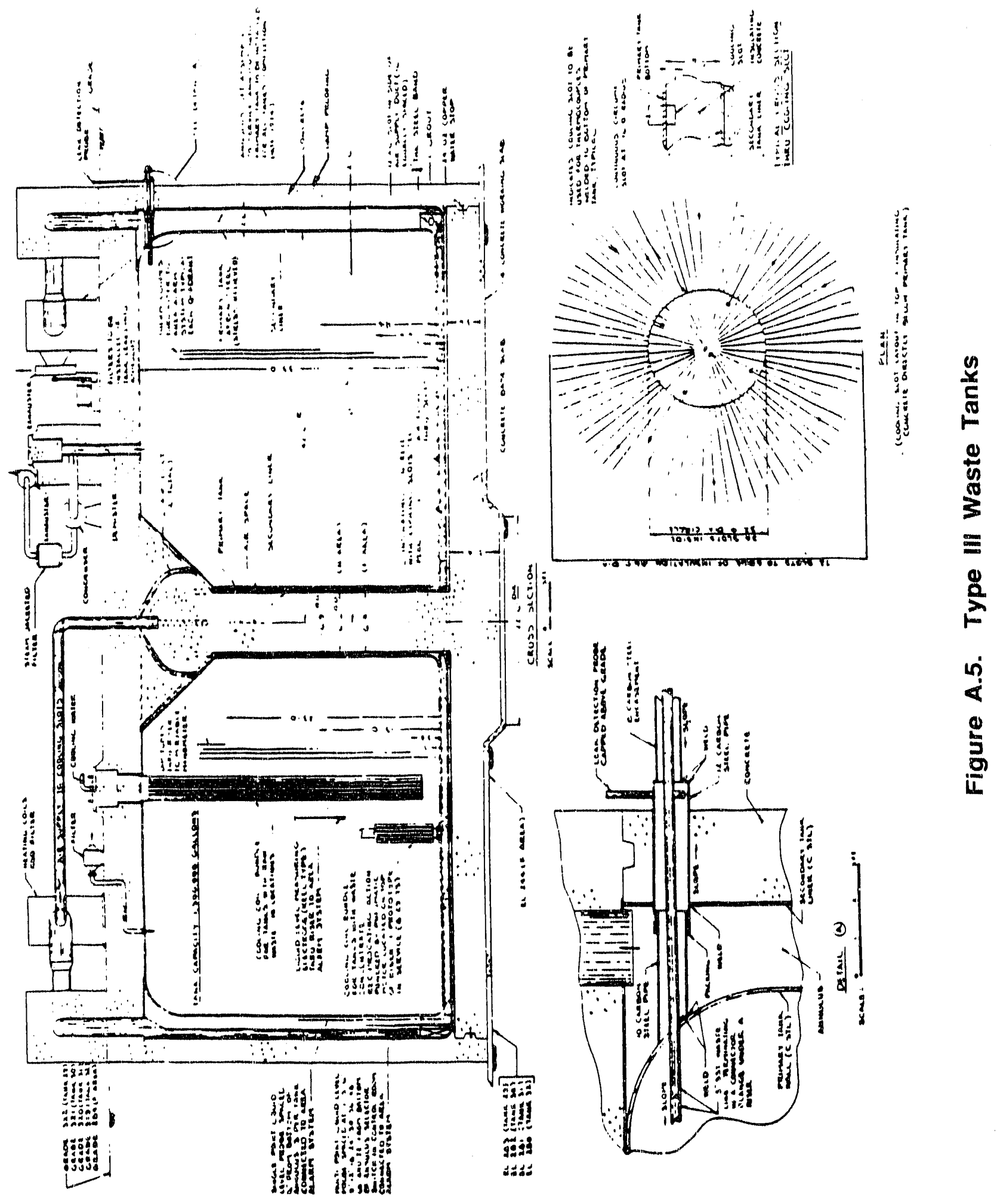


Each primary vessel of a Type III is made of two concentric cylinders joined to washer-shaped top and bottom plates by curved knuckle plates. Plate thicknesses are the following:

Top and bottom - $1 / 2$ inch

Upper knuckle $-1 / 2$ inch

Inner wall

Upper band $-1 / 2$ inch

Middle band - $5 / 8$ inch

Lower band $-3 / 4$ inch

\author{
Inner wall \\ Upper band $-1 / 2$ inch \\ Lower band $-5 / 8$ inch
}

The plates used were open hearth steels made to fine grain practice. Tanks $29 \mathrm{H}-32 \mathrm{H}$ and $33 \mathrm{~F}$ $34 \mathrm{~F}$ built before FY 74 were from ASTM A516-Grade 70, hot-rolled steel. Tanks 25F-28F, 35H$37 \mathrm{H}$, and $44 \mathrm{~F}-47 \mathrm{~F}$ were from ASTM A516-Grade 70, normalized steel. Tanks $38 \mathrm{H}-43 \mathrm{H}$ and $48 \mathrm{H}-51 \mathrm{H}$ were from ASTM A537-Class I steel. All three steels are essentially the same composition. The normalizing heat treatment (analogous to annealing) optimizes notch toughness and hence increases resistance to brittle fracture. ASTM A537-Class I is normalized steel also and has lower maximum concentration for several common impurities.

The primary tank sits on a 6 -inch bed of insulating concrete within the secondary containment vessel. The concrete bed is grooved radially so that ventilating air can flow from the inner annulus to the outer annulus. Any liquid leaking from the tank bottom or center annulus wall would move through the slots and would be detected at the outer annulus.

The secondary vessel is 5 feet larger in diameter than the primary vessel, with an outer annulus $2-1 / 2$ feet wide. The secondary vessel is made of $3 / 8$-inch steel throughout. Its sidewalls rise to the full height of the primary tank. The nested two-vessel assembly is surrounded by a cylindrical reinforced concrete enclosure with a 30 -inch wall. The enclosure has a 48 -inch-flat-reinforced concrete roof which is supported by the concrete wall and a central column that fits within the inner cylinder of the secondary vessel.

Because of a high water table, the tanks in H Area are elevated above natural grade and surrounded with mounded earth. A lower water table in F Area permitted installation of Tanks $25 \mathrm{~F}$ to $28 \mathrm{~F}, 33 \mathrm{~F}, 34 \mathrm{~F}$, and 44 to $47 \mathrm{~F}$ with their tops flush with natural grade. Because the tanks are above predicted water tables, only standard water-proofing was applied to the concrete enclosure.* The 48-inch concrete covers for these tanks reduce the radiation field above any of them with HHW in the tank to less than the amount permissible for continuous occupancy by operating personnel $(6 \mathrm{mR} / \mathrm{hr}$, ERDAM $0524 ; 0.5 \mathrm{mR} / \mathrm{hr}$, DOE Order 5480.11); hence, no earth overburden is required.

* Highest measured water table is at least 3 feet below the Type III tank bottoms. 
Savannah River Site Interim Wastc Management

Program Plan--FY 1991-1992
Appendix III

Tank Construction and Operating History

May 1992

All butt welds on the primary tanks, except welds on the horizontal roof surface, and all butt welds on the secondary tank, joining bottom plates, knuckle plates, and the lowest courses of center-column and outer-wall plates were radiographically inspected. Defects were corrected, and then they were rechecked radiographically. Beginning with the 1974 tanks, all plate welds in the secondary tanks were radiographically inspected. All spots on the inside or outside of the primary tanks or the inside of the secondary tanks, where clips or lugs were removed or where other excisions were made, were examined by magnetic particle or liquid penetrant techniques. Any defects 'vere repaired. All butt welds on the secondary tanks were vacuum leak-tested. All welds in the bottom assemblies of the primary tanks, including knuckle rings and lowest course welds, were vacuum leak-tested before each bottom assembly was lowered into final position and then tested a second time after the stress-relieving operation. A full hydrostatic test, consisting of filling each primary tank to a depth of 32 feet and allowing it to stand 48 hours, was conducted after stress relieving. No leaks were found by the hydrostatic tests. All circumferential welds in the pipe loops of the removable coil bundles below the $1 / 2$-inch-thick plate at the base of the riser plug were radiographed. The assembled cooler piping was tested hydrostatically to 500 psi and halide leak-tested at $30 \mathrm{psi}$.

Each primary tank was stress-relieved in place after all burning, cutting, welding, and other high-temperature work below the liquid fill line liad been completed. Full stress relief at $1100^{\circ} \mathrm{F}$ was accomplished in accordance with the general requirements of the ASME Boiler and Pressure Vessel code.

The top openings into the Type III tanks and annular spaces are much like those in Types I and II tanks. They are closed with stepped concrete plugs (lead plugs in a few cases), and the openings are used for instrumentation, cooling units, or ventilation system connections.

Cooling of liquid waste in the first seven Type 111 tanks (Tanks $29 \mathrm{H}$ through $35 \mathrm{H}$ ) built is accomplished by means of removable cooling coil bundles (Figure A.6) that are suspended in the tank through the concrete roof. A maximum of 10 cooling units can be suspended in each tank through risers. Each cooling unit has a heat removal capacity of $600,000 \mathrm{Btu} / \mathrm{hr}$ from treely convective liquid waste. All other Type III tanks except for the first seven have permanently installed cooling coils similar to those in Types I and II tanks. In fresh waste service (liquid plus about 8 percent sludge), total heat removal capability, $6,000,000 \mathrm{Btu} / \mathrm{hr}$, is the same for either cooling coil design.

Bundles of closely spaced coils are satisfactory for cooling liquid wastes, including fresh waste with maximum heat output, because convection circulates the liquid and thereby carries the heat from remote regions of the tank to the widely spaced bundles. However, in tanks receiving evaporator concentrate, cooling surfaces soon become encrusted with crystallized waste salts and all heat must flow through the deposited salt by conduction, which is a relatively inefficient process. Hence, the coils must be distributed as widely as practical throughout the tank so that a maximum volume of solid salt can be accumulated before the salt thickness of any one coil becomes ton great to pass its share of the heat to be dissipated. For this reason, all Type III tanks built after Tank 35 were provided with bottom-supported vertical coils on 3-foo-triangular centers. (Types I and II tanks have duplicate coils on 4 -foot-triangular centers.) Unlike the Types I and II tanks, Type III tanks are not provided with horizontal coils near the tank bottom; the Type III bottoms are cooled by forced air flow underneath the bottom. 
Savannah River Site Interim Waste Management Program Plan--FY 1991-1992
Appendix III

Tank Construction and Operating History May 1992

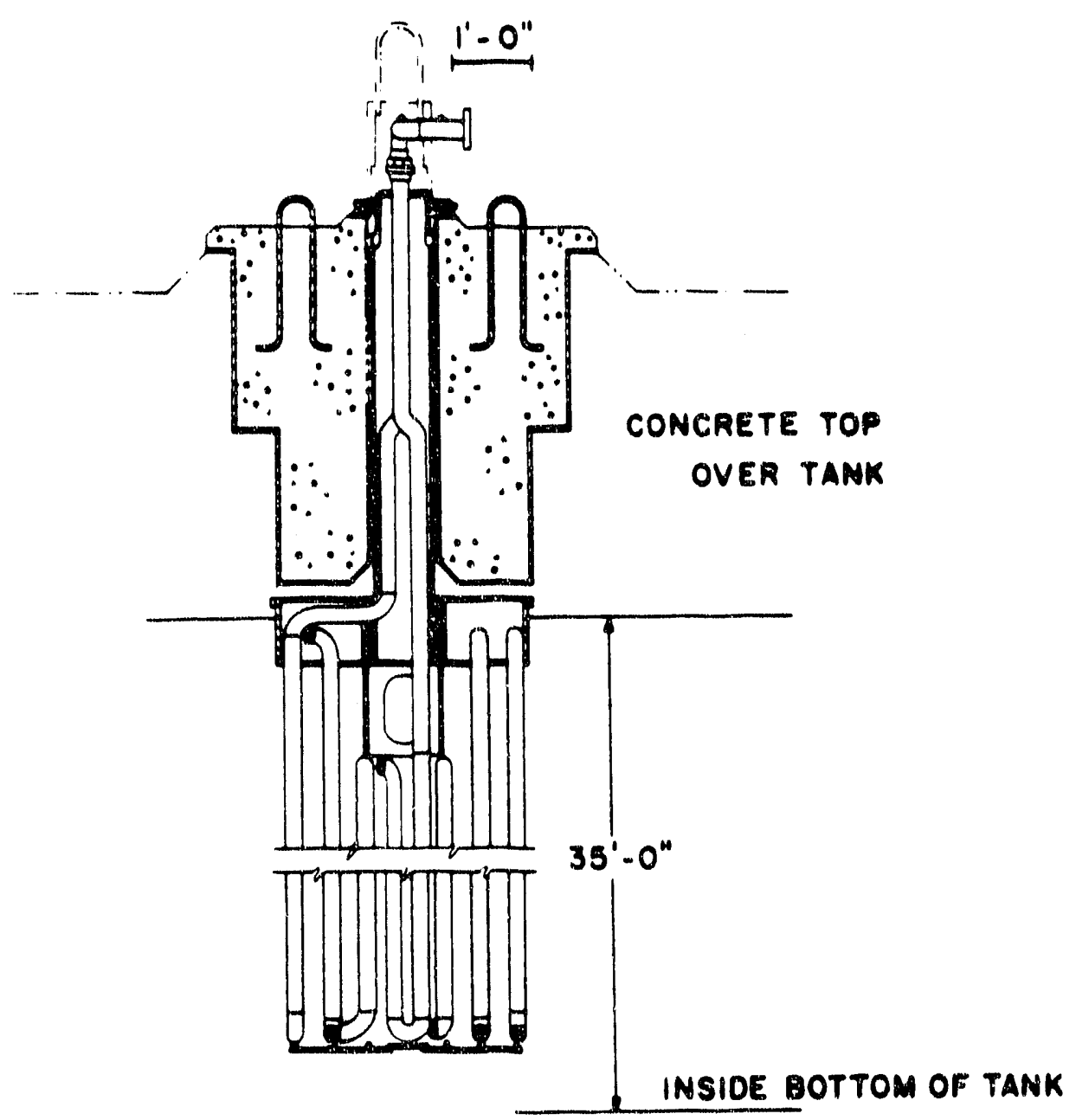

Figure A.6. Removable Cooling Coll, Type III Tanks 
Savannah River Site

Interim Waste Management

Program Plan--FY 1991-1992
Appendix III

Tank Construction and Operating History

May 1992

Because installation of uniformly distributed cooling coils in the old Type III tanks already in service is not practical, those in concentrate or high heat service (Tanks $29 \mathrm{H}, 30 \mathrm{H}, 31 \mathrm{H}, 33 \mathrm{~F}$, and $34 \mathrm{~F}$ ) have been provided with deployable coolers. The coolers are inserted through the available roof ports and then expanded horizontally to distribute their cooling surfaces more widely than in the case with the consolidated bundles of Figure A.6. Two models of deployable coolers are in use. The early model, of which four units are installed in Tank 33F and seven in Tank 34F, has 11 double-pipe (hairpin) elements in a conical configuration with a base diameter of 24 feet. Eighteen cylindrical units are in service (four in Tank $29 \mathrm{H}$, five in Tank $30 \mathrm{H}$, two in Tank $31 \mathrm{H}$, four in Tank 33F, and three in Tank 34F). One of three deployable coolers installed in Tank 31H failed during installation and is not serviceable. This model deploys at both top and bottom into a cylindrical configuration 16 feet in diameter, with 20 single-pipe elements. Both deployable models are nominally 30 feet high, although most units have somewhat shortened elements to clear the salt layers already on the bottoms of the tanks at the time of installation. Tanks $29 \mathrm{H}$ and $31 \mathrm{H}$ also have five consolidated bundles in place. Tanks $32 \mathrm{H}$ and $35 \mathrm{H}$, which store liquid waste, have five consolidated bundles each. Figure A.7 shows the basic configuration of the three types of insertable-coolers.

The ventilation systems for Type III primary tanks are negative pressure systems designed for purging the interior volume at a rate in excess of $100 \mathrm{cfm}$. In a typical installation, air enters through a HEPA filter and is conducted by a 4-inch pipe through the roof into the waste storage space. Air leaves the storage space by way of a 12 -inch riser pipe positioned across the tank from the inlet. The exhaust air first passes through a demister in the riser, which intercepts droplets and returns them to the tank. Then the air passes through a condenser to extract potentially radioactive moisture, to a heater to raise the air temperature above its dew point (to prevent water vapor from condensing in the HEPA filters), and through a HEPA filter to remove solid particles. The air is finally discharged to the atmosphere through an exhaust blower. Hydrogen and radioactivity detectors to monitor the effluent air have been installed on Tanks $29-32 \mathrm{H}$ and $33-34 \mathrm{~F}$ and are original equipment on FY 1974-78 Type III tanks.

The ventilation and dehumidification systems for Type III annuli differ from those installed at Types I and II tanks. Warmed air flows directly into the outer annulus of all three types. In addition, air is drawn through the inner annulus around the center column of the Type III tanks, passes beneath the primary tank through the radial grooves in the concrete base slab, and exhausts into the outer annulus. Dampers are installed in the inlet ducts to both the outer and inner annuli. In Tanks $29-32 \mathrm{H}$ and $33-34 \mathrm{~F}$, the radial grooves have a capacity of $2000 \mathrm{cfm}$ when all flow is directed to the inner annulus. Normally, both dampers will be open, increasing the total flow to $4000 \mathrm{cfm}$, which is divided between the inner annulus $(1200 \mathrm{cfm})$ and the outer annulus $(2800$ efm). The Type III tanks built in FY74 or after have larger radial grooves which give the ventilation systern a capacity of about $8000 \mathrm{cfm}$ to the inner annulus. All the FY74-78 anks are equipped with 3-hp fans except Tank $39 \mathrm{H}$, an HHW receiver, which is equipped with a 10-hp fan to give the $8(0)(0 \mathrm{~cm}$ flow. The incriased flow is to aid in cooling the tank bottom. All of the Type III annuli are ventilated under negative pressure by means of exhausters. Radioactivity monitors have been provided on the annulus effluent air of all Type III tanks. Enclosures for installing HEPA filters are provided. 
Savannah River Site Interim Waste Management

Program Plan--FY 1991-1992
Appendix III

Tank Construction and Operating History May 1992

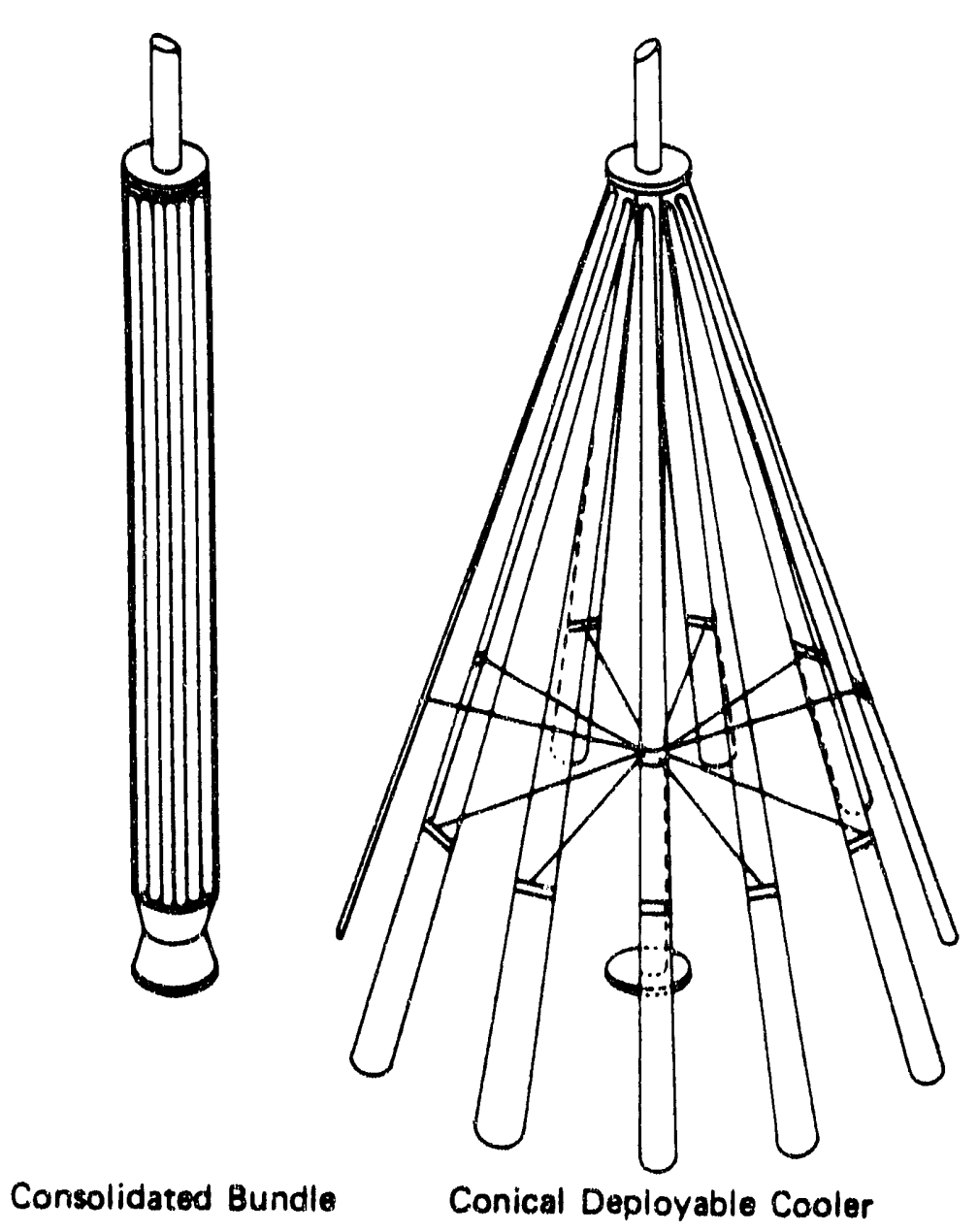

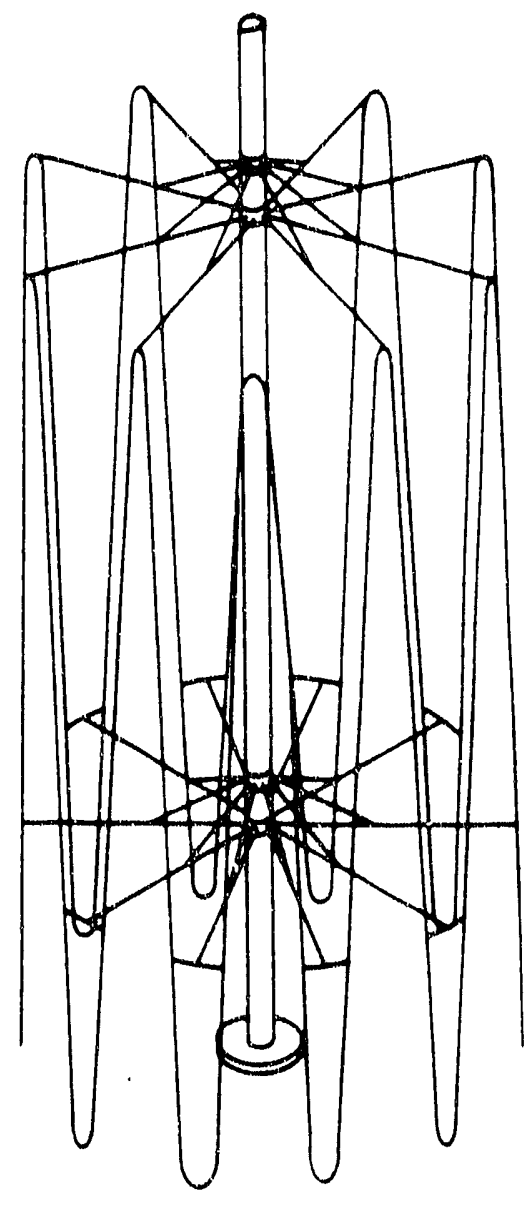

Cylindrical Deployable Cooler

Figure A.7. Insertable Coolers for Type III Tanks 29-35 
The principal instrumentation provided for each Type III tank consists of:

- Liquid Level. The amount of liquid waste is determined by a conductivity probe on the end of a calibrated tape which is reeled in or out by a motor drive. A stationary conductivity probe is used to detect high level as a backup to the reel tape.

For each tank, four stationary conductivity probes are provided, one in each quadrant, for determining the presence of liquid in the annulus. Three of the probes are single-point devices, and the fourth is a multipoint probe that can obtain an approximate determination of the liquid leval in the annulus as well as the indication of leakage. Evidence of leakage into the annulus, as well as high liquid level in any of these waste tanks, is signaled to the tank farm control room.

- Temperature. A stainless steel thermowell is installed in each of four tank-top plugs, spaced $90^{\circ}$ apart, on each Type III waste tank. From three to seven thermocouples are installed in each thermowell, one at one inch from the tank bottom and the others at higher elevations. Temperatures are recorded in the control room. In addition, the primary vessel steel wall, bottom temperatures, the cooling water temperatures, and the tank vent temperature are measured.

Pressure and Flow. The water supply line to the cooling units for each tank is equipped with a pressure gage, and connections for a portable flowmeter are provided (flow gages are installed on several tanks). Each cooler is equipped with a pressure relief valve on the inlet piping and a pressure gage on the outlet. In the lank primary ventilation system, tank static vacuum, vacuum downstream of the filters, and differential pressures across the HEPA filter and across the demister can be measured for each tank. Differential pressure switches are installed to signal vent exhauster failures and plugged filters. In the annulus ventilation system, filter differential pressure, exhauster inlet vacuum, and annulus vacuum are also measured.

\section{Type IIIA Tanks}

The primary means for detection of leakage from the primary vessels is the same for all three types of cooled tanks; instrumented and visual surveillance for liquid in the secondary pan or liner under the annular space between the free-standing primary tank and the secondary vessel. Conductivity probes, supplemented by pneumatic bubbler tubes (dip tubes), are installed in each tank annulus to provide automatic early warning if a liquid accumulates in the annulus. Evidence of leakage into an annulus, as well as high-liquid level in any of these waste tanks, is signaled to one of the tank farm control rooms. Access risers in each tank annulus permit direct visual inspection of the annulus pan. Beginning with the FY-1974 tanks (Tanks 35H through 37H), new Type III tanks were provided with 14 annulus inspection ports (plus the four large risers); these permit inspection by periscope and direct photography of all the primary tank wall outer surface. In 1982, Tanks 29 through 34 that were built with only four large annulus risers were each retrofitted with 14 to 15 additional small risers to permit inspection of essentially all of the tank annulus.

Beginning with the waste tanks constructed under Project $75-1-\mathrm{A}$ ( $25 \mathrm{~F}$ through $28 \mathrm{~F}$ ), an additional improvement in leak detection capability was added (Figure A.8). This latest design feature permits verification of the integrity of the secondary tank should the primary tank leak or if 
Savannah River Site

Interim Waste Management

Program Plan--FY 1991-1992

Appendix III

Tank Construction and

Operating History

May 1992

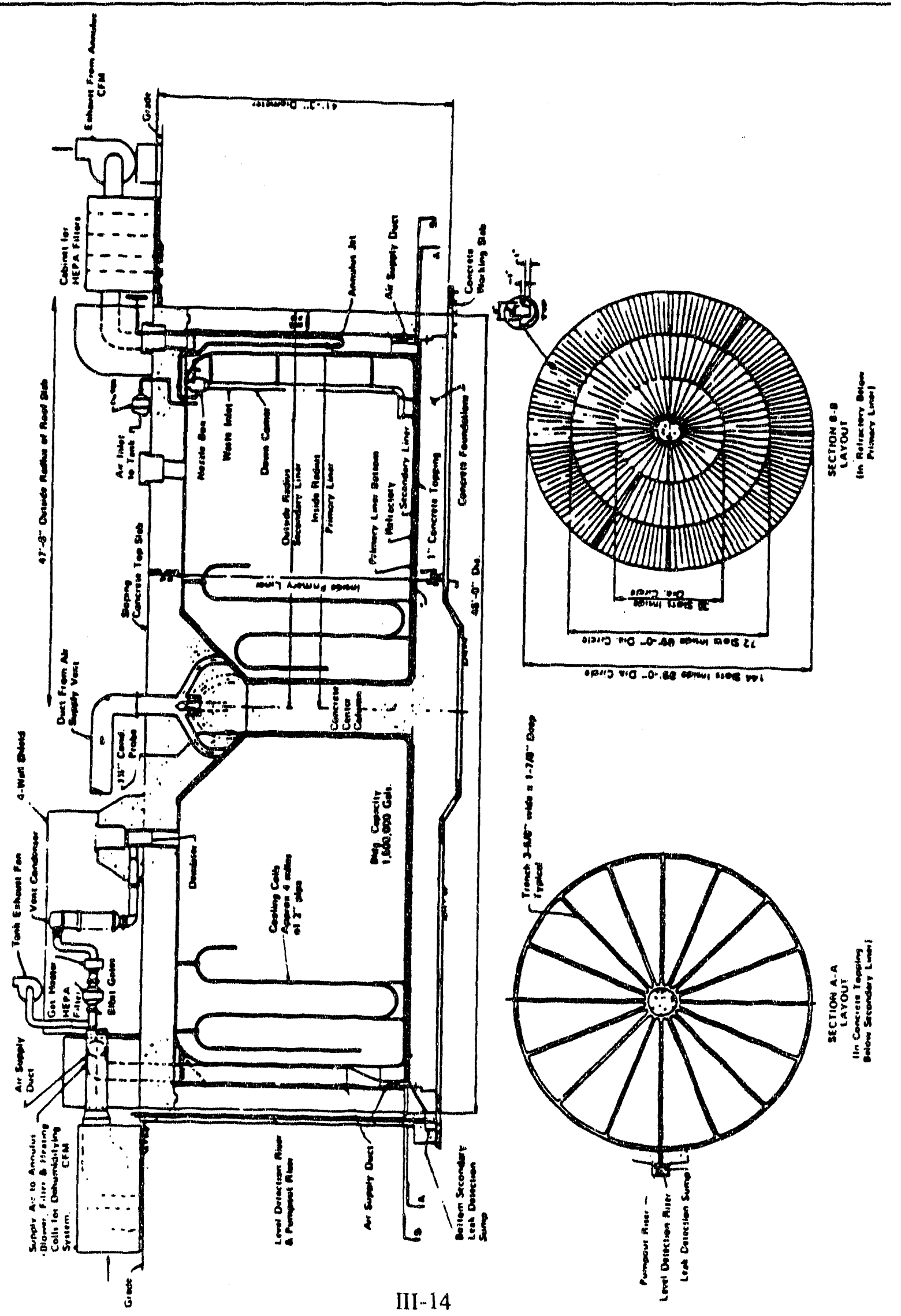

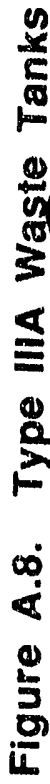


any other liquid collects in the annular space between the primary and secondary tank. Leak detection for the secondary tank has been provided by a grid of interconnected radial channels inside the concrete base slab on which the secondary tank rests for all tanks constructed since Tanks $35 \mathrm{H}$ through $37 \mathrm{H}$. The channels are sloped to drain through a collection pipe to a sump inside the concrete enclosure around the tanks. An access pipe rises to grade from the sump to allow for liquid measurement, sampling, and pumpout of collected liquid. Leak detection procedures and equipment are discussed in more detail in Section VI of the main body of this document.

\section{Type IV Tanks}

Tanks $17-20 \mathrm{~F}$ and $21-24 \mathrm{H}$ are of a different design than those previously described and are called single-wall, uncooled, or Type IV tanks.* They are designed for storage of waste that does not require auxiliary cooling. Tanks $17 \mathrm{~F}$ through $20 \mathrm{~F}$ were built in F Area in 1958, and Tanks $21 \mathrm{H}$ through $24 \mathrm{H}$ were built in $\mathrm{H}$ Area from 1959 to 1961 . Each tank holds $1,300,000$ gallons, is 85 feet in diameter, and is 34 feet high (Figure A.9).

Each Type IV tank is basically a steel-lined prestressed concrete tank in the form of a vertical cylinder with a domed roof. Carbon steel plates, $3 / 8$ inch thick, were used to form the cylindrical sides and flat bottom portions of the steel liners. The knuckle plates at the juncture of the bottom and the side wall are 7/16-inch thick. Concrete was built up around the steel vessel by the "shotcrete" technique, a pneumatic method of application in which a thick semifluid mixture is blown through a nozzle to form a builtup structure. A dense, high-strength concrete is formed which enhances the load-carrying capability of the wall. No secondary steel pan was provided for these tanks. The wall was prestressed by embedding girths of steel under tension in the outer layers of the wall, thereby applying a compressive force to the inner layers and to the steel liner. When a tank built in this manner is filled, the outward pressure of the contained fluid offsets, approximately, the compressive prestresses in the inner layers of the concrete. In effect, the concrete wall becomes a structure with negligible internal circumferential stresses, and the burden of the tank's contents is transferred to the steel bands near the outer surface of the concrete.

All welds in the steel liners were x-rayed. All of the welded tank-bottom seams and the upper seams of the knuckle rings were vacuum leak tested. Each tank was hydrostatically tested by filling with water to the normal fill line before the backfilling operation and then was allowed to remain filled until the time to be placed in use for waste storage.

Leak detection for the bottoms of these tanks is provided by a grid of channels in the concrete foundation under the tank that drain to a sump outside the periphery of the tank wall. A 4-inch pipe rises to grade from the sump to allow for liquid-level measurement, sampling, and pumpout of collected fluid. To detect gross leakage through the sidewalls, an additional leak detection feature was provided for the H-Area tanks in the form of a circumferential open-topped drainage channel, filled with crushed stone, outside the concrete tank wall adjacent to the wall foundation.

* Tank Types I, II, and III all have water cooling. The Type IV designation was applied to the uncooled tanks many years after their construction and is not intended to denote chronological sequence of design and/or construction. 


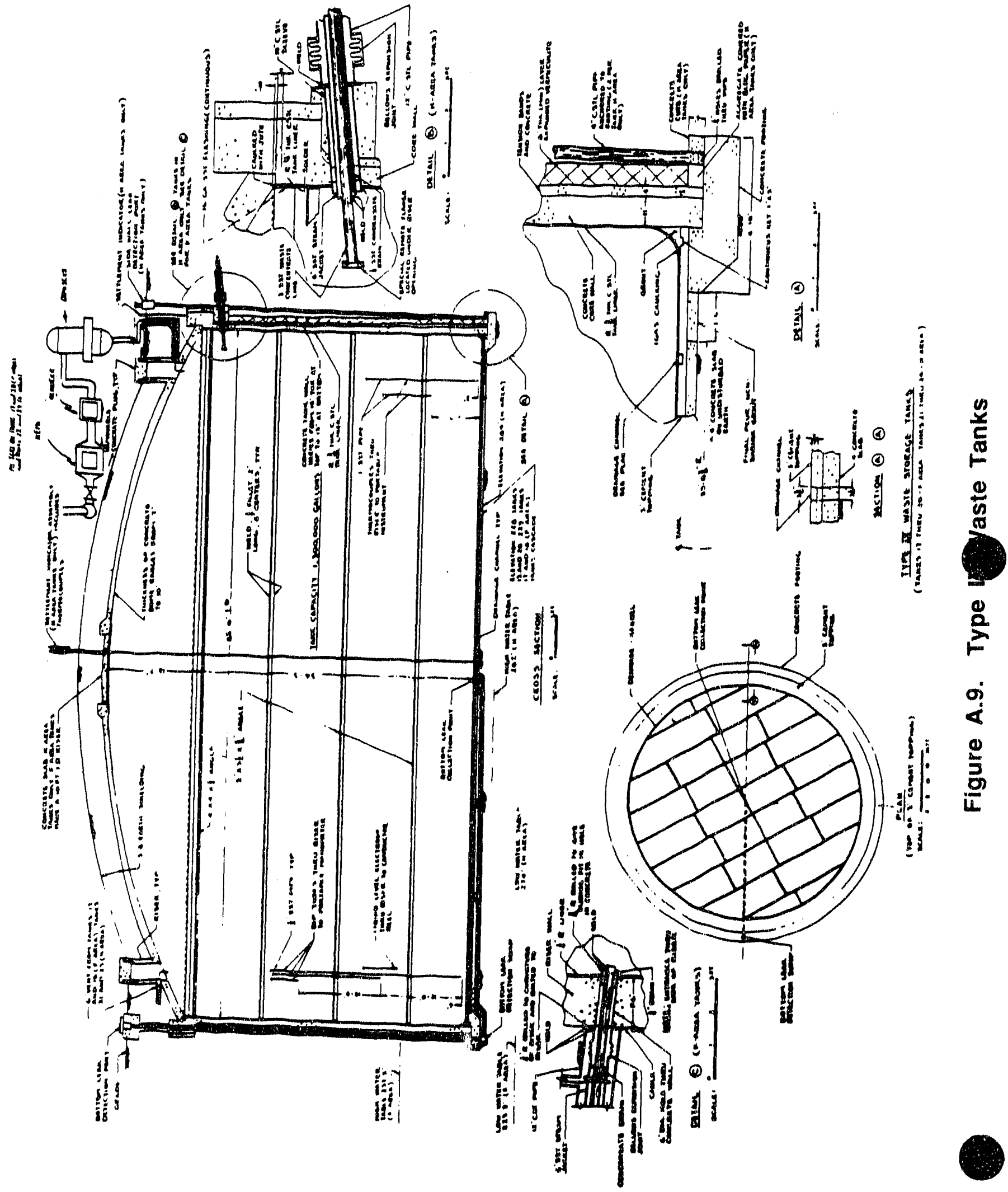


Two vertical pipes, $180^{\circ}$ apart, were installed down to the channel to provide a means for detecting leakage, should any come through the tank wall and drain into the gutter. Unfortunately the gutters are submerged in groundwater "perched" above the concrete working pad around the tank bases; this groundwater hinders the sensitivity of the system.

Radiation shielding of the Type IV tanks in F Area was accomplished by applying at least 32 inches of earth over each of the 7-inch-thick concrete domes. H-Area tanks were shielded similarly, except that the earth cover was at least 44-inches thick to accommodate a somewhat higher radiation level from the waste.

The Type IV tanks are connected so that a single exhaust system provides interior purge through pairs of tanks ( $17 \mathrm{~F}$ to $19 \mathrm{~F}, 18 \mathrm{~F}$ to $20 \mathrm{~F}, 21 \mathrm{H}$ to $22 \mathrm{H}$, and $23 \mathrm{H}$ to $24 \mathrm{H}$ ). However, there is a valve between the two tanks so that the systems can be operated independently by connecting a portable H\&V system to one of the tanks (a second permanent system has been installed on Tank $23 \mathrm{H}$ ). The original exhaust filter housings were packed with fiberglass mattering in layers of various densities. HEPA filters have been substituted in the exhaust at Tanks $19 \mathrm{~F}, 20 \mathrm{~F}, 22 \mathrm{H}$, and $24 \mathrm{H}$. All tanks have forced negative exhaust ventilation.

Instruments for in-tank measurements are installed through the risers in tank dome openings. The principal instrumentation systems provided for each tank are as follows:

Liquid Level. The amount of liquid in a tank is determined by means of a conductivity probe on the end of a graduated tape that is reeled in or out by a motor drive. A stationary probe is used for backup high-level detection. The level in each leak detection sump is continuously monitored, while the level in the sidewalls is determined by the operators on a periodic basis.

- Temperature. Originally, at least two thermowells were provided in each tank. Each thermowell held two thermocouples, one for bottom temperature and one for measurement at an intermediate elevation. However, because of the waste removal program, each tank now only has one thermowell.

Tank 20 is the only Type IV tank known to have leak sites in the steel liner. While no waste has been detected outside of the tank, three leak sites have been identified in the steel liner above the waste level. It is suspected that groundwater initiated the leaksite from outside of the wall. Since the penetration was detected in 1984, waste removal from this tank has been accomplished.

\section{Stress Cracking and Leakage of Primary Waste Tanks}

In 1961-1962, following leakage from Tanks $9 \mathrm{H}, 10 \mathrm{H}, 14 \mathrm{H}$, and $16 \mathrm{H}$, about 134 (Tank $16 \mathrm{H}$ ) and 25 (Tank $14 \mathrm{H}$ ) leak sites were observed by periscope on the primary tank walls, as defined by accumulations of dried salt. No leak sites were visible during limited inspections of Tanks $9 \mathrm{H}$ and $10 \mathrm{H}$, even though these two tanks, like Tanks $14 \mathrm{H}$ and $16 \mathrm{H}$, contained appreciable amounts of dried waste in the annular spaces. Up to the present time, five of the Type I tanks (1F, $9 \mathrm{H}, 10 \mathrm{H}, 11 \mathrm{H}, 12 \mathrm{H})$ and all four of the Type II tanks $(13 \mathrm{H}, 14 \mathrm{H}, 15 \mathrm{H}, 16 \mathrm{H})$ have experienced some leakage from the primary tank to the annular space inside the secoridary container (one tank in F A rea and eight tanks in $\mathrm{H}$ Area). The observed leaks have occurred through small hairline cracks that are usually adjacent to welds. The rate of this leakage has been very small except for the leakage from Tank $16 \mathrm{H}$. All tank annuli are purged with air to dehumidify the space and 
evaporate any leakage to dry, immobile salt. Waste removal from these tanks is currently forecasted to be completed in 2002 .

Tank $9 \mathrm{H}$ was the first H-Area tank in HHW service [from natural uranium (Purex) processing], beginning in July 1955. Leakage of waste into the annulus pan was first confirmed in October 1957, but may have occurred as early as February 1957. Estimates of the volume of leakage from the primary tank in 1957 range from 3000 to 16,000 gallons. The initial waste leakage was flushed back into the primary tank in 1958-59 with a series of water flushes totaling 15,000 to 20,000 gallons. Slow leakage of waste into the annulus and evaporation therein 15,000 to 20,000 gallons. Slow leakage of waste ing between 2 and 12 inches. Subsequently,
continued until 1964 , with the salt or liquid level ranging bed about the
8 to 10 inches of damp salt cake has remained in the annulus pan. It will be removed at aboustement/Waste same time the waste salt is removed from the primary tank, as part of the Tank Replacement/Waste Transfer program. The exact site(s) of the leak(s) in the Tank 9 primary has (have) not been located; only about one-fourth of the primary wall is visible from the four inspection entry ports (risers) provided in the Type I tanks.

The storm sewers at Tanks 9-12 in H Area are sometimes slow to drain, and storm water has pooled around the tank risers. As a result, water has occasionally leaked into primary and annulus risers of Tanks 11 and 12 which are the lower pair of the four tanks. Concrete dikes three feet high were erected around each of the four tanks in mid-1984.

Leakage rates from the other cracked Type I primary tanks have been less than those from Tank $9 \mathrm{H}$. Yellow crystalline solid material was first discovered in the Tank $10 \mathrm{H}$ annulus pan in July 1959, 3-1/2 years after the tank began receiving high-heat Purex waste. (The tank was 93 percent full by September 1956.) Unlike Tank $9 \mathrm{H}$, free liquid was observed in the Tank $10 \mathrm{H}$ annulus only a few times, and in some of these cases, inleakage of rainwater was suspected. Measured salt height in the pan has ranged up to about $2-1 / 2$ inches. As in Tank $10 \mathrm{H}$, no leak sites have been found in the visible sections of the primary tank wall.

Leakage from the other three cracked Type I primary tanks has been much less, with dried salt deposits covering relatively small areas of the walls of Tanks $11 \mathrm{H}$ and $12 \mathrm{H}$ and the pan floor of Tank 1F. The Tank IF leak apparently is in the primary bottom. Many years elapsed between initial filling of these three tanks and the appearance of the telltale sait deposits.

Tank $16 \mathrm{H}$ is the only SRS waste tank from which waste leakage through cracks in the primary tank has actually reached the ground surrounding the tank. The tank began receiving fresh HHW from enriched uranium (HM) processing in late May 1959. Minor leakage was detected in November 1959 from the primary tank to the annular space inside the secondary container and November 1959 from the primary tank to the annular space 1960 , a large number of very small
concrete vault of Tank $16 \mathrm{H}$. Subsequently, during September 1 .
leaks resulted in a leak rate of about 4 gallons/minute, and the level of waste in the annular space exceeded the 5-feet height of the steel pan for an estimated period of six hours while a transfer jet was being installed in the annulus to remove the leaked waste. The waste rose above the top of the steel pan liner, and some overflowed into the clearance space between the concrete tank and the steel pan. Leakage from the primary tank was stopped by reducing the liquid level inside the tank below the major leak sites. To prevent possible future overfilling of the tank pans in the event of major primary tank leaks, jets of 75 gallons/minute capacity have been installed in the annular spaces of the tanks so that leaked liquid waste may be rapidly returned to primary storage. 
A maximum of 700 gallons of alkaline waste rose above the top of the 5-foot-high steel pan liner of Tank $16 \mathrm{H}$. Intensive inspection and monitoring over the intervening years confirm that almost all of these 700 gallons were contained in the concrete vault, and the quantity of waste leakage into the soil was limited to a few tens of gallons of waste containing about $7 \mathrm{Ci}$ of radioactivity per gallon (primarily Cs-137). Because the tank bottom is below the surface of the water table, the radioactivity that reached the soil also immediately reached the groundwater. The soil in this area contains clay with a significant ion exchange capacity, and consequently, during the ensuing 19-year period, the radioactivity has moved only a few additional feet. The limited migration has been confirmed by extensive sampling and testing with encased wells. The radioactivity level in the groundwater 15 feet from the edge of the concrete pad under Tank $16 \mathrm{H}$ is about 10 times normal background, 5 to $15 \mathrm{pCi} / \mathrm{L}$, and between $2 \times 10^{-4}$ and $4 \times 10^{-4} \mathrm{Ci}$ of radioactivity is estimated to have moved beyond this point. Continued use of Tank $16 \mathrm{H}$ was restricted to a reduced volume (below the worst cracks) until it was removed from liquid storage service in early 1972. Almost all of the salt was removed from the annulus in 1977, and the sludge was removed from the primary tank in 1978-1979. Decontamination of the tank interior with water and oxalic acid sprays was completed in 1980. Further details on leakage from Tank $16 \mathrm{H}$ may be found in DP-1358.

Investigation of the cracking in Tank $16 \mathrm{H}$ showed: (1) that stress-corrosion cracking in welded areas of the tank was a likely cause, and (2) that full stress relief of the tanks after fabrication would eliminate this type of stress cracking. All observed tank leaks have occurred at hairline cracks that are usually adjacent to welds. Corrosion samples exposed to waste in the waste tanks and in simulated waste prepared in the laboratories indicate the stress-corrosion cracking is the most likely explanation of the leaks. The design for the Type III tanks, previously described, evolved as a result of these investigations.

Tank $14 \mathrm{H}$ began receiving fresh high-heat Purex waste in September 1957; the first leakage into the secondary pan was discovered in May 1959, and flow into the tank was discontinued for 10 months. The liquid level at the time was just above the middle horizontal weld, and there was strong evidence that this was the site of the major leak (small additions of fluorescent-tagged liquid to the primary tank promptly showed up in the annulus pan); however, eventual inspection of almost 100 percent of the tank wall (through additional access holes drilled through the tank roof) has not revealed a leak site at this elevation. All except one of the approximately 50 leak sites found in Tank 14H are near the bottom of the tank; but in February 1974, a single site was found 31 inches above the top horizontal weld. Liquid in the tank did not reach this level until October 1970, and this liquid was high in aged waste concentrate supernate, normally considered to inhibit stress corrosion cracking. Leaked liquid waste was jetted intermittently from the Tank $14 \mathrm{H}$ annulus back into the primary tank, maintaining a maximum salt and liquid level in the annulus pan of about 15 inches. It will be removed as part of the tank replacement/waste transfer program.

The first two of some 13 leak sites found in Tank 15H in April 1972 were at wall locations free from leaks when inspected ten years earlier. Tank $15 \mathrm{H}$ entered active service in October 1960 , when it received 369,000 gallons of HM HHW supernate removed from leaking Tank $16 \mathrm{H}$. The remaining Tank $15 \mathrm{H}$ leaks were found in previously uninspected areas in March-June 1973 through new access ports. Generally, the salt deposits extended down the wall to the annulus pan but did not appear to have spread very far horizontally around the pan.

Tank $13 \mathrm{H}$ was placed in service in December 1956, receiving fresh low-heat waste (LHW) from the Purex (natural uranium) process. It has been the $242-\mathrm{H}$ evaporator feed tank since 
January 1976 . Before 1976 , it was the only route from most of the other H-Area tanks to Tank $21 \mathrm{H}$ (then the evaporator feed tank), so Tank $13 \mathrm{H}$ has been exposed to every type of waste experienced in $\mathrm{H}$ Area except fresh HHW. No evidence of stress cracking or primary tank leakage was found until April 1977, despite inspection of about 95 percent of the tank wall. At that time, a sizeable salt deposit extending most of the way down the tank wall from the 279-inch level was found. Surveys of the same wall area showed no salt deposit in December 1974 and March 1976. A second leak site was found at the 269 -inch level in 1980. Leakage was limited to formation of nodules of dried salt approximately one-inch in diameter. The tank is continuing in service as the evaporator feed tank, but will be emptied and decontaminated as part of the Tank Replacement/ Waste Transfer Program (as all Types I, II, and IV tanks will be). The current operating limit is below the leak sites.

Periscopic inspection in December 1983 showed three wet spots on the interior of the steel liner of Tank 20. In April 1984, one of the three wet spots was cleaned, and dye penetrant was tested. While the failure mechanism was not determined, a failure in the liner was found at the site when water leaked through the liner at the site during the test. Since the other two wet spots appeared essentially the same as the one tested, these were also deemed to be failure sites. These sites are well above the level of waste stored in the tank. While inleakage has occurred at these three failure sites in the steel liner of Tank 20, no waste has been detected outside the tank. Tank 20 was placed in service in March 1960 receiving and storing a mixture of low-heat and HHW concentrate from the 242-F evaporator. Beginning in June 1980 until December 1981, Tank 20 underwent density gradient salt removal. About 714,000 gallons, 66 percent of the original salt, was removed. From January 1982 until 1986, Tank 20 remained inactive. In 1986 efforts began to remove the remaining 378,000 gallons of salt by mechanical agitation. Salt removal from the Type IV tanks was completed in September 1986.

\section{Review of Corrosion and Stress Cracking Mechanisms}

Four distinct forms of corrosion attack may be observed in systems such as the waste tanks.

- General corrosion: the surface is attacked uniformly, resulting in a gradual thinning of the structure.

- Pitting: the surface is attacked at very localized sites, forming relatively deep pits or crevices. Pitting may cause very rapid penetration of the structure.

- Beachline attack: the metal is attacked more rapidly at the liquid-air (vapor) interface.

- Stress corrosion cracking (SCC): under the influence of an internally or externally imposed stress and a slightly corrosive environment, the metai cracks at an externally imposed load much lower than its normal tensile strength.

Significant general corrosion has not been observed in the waste tanks as evidenced by the inspection program (both wall thickness measurements and direct observation), as well as by the performance of in-tank corrosion coupons. 


\section{Stress Corrosion Cracking}

Nitrate-induced stress corrosion cracking (SCC) has occurred in the primary of nine of the original 16 waste storage tanks, which were placed in service between 1955 and 1959 . These consist of five Type I tanks $(1 \mathrm{~F}, 9 \mathrm{H}, 10 \mathrm{H}, 11 \mathrm{H}, 12 \mathrm{H})$ and four Type II tanks $(13 \mathrm{H}, 14 \mathrm{H}, 15 \mathrm{H}$, $16 \mathrm{H})$. No cracking has been observed in seven of the original sixteen tanks $(2 \mathrm{~F}, 3 \mathrm{~F}, 4 \mathrm{~F}, 5 \mathrm{~F}, 6 \mathrm{~F}$, $7 F, 8 F)$, nor in the 35 waste tanks of Types III and IV design, built and put in service after 1960.

The design and fabrication procedures for the Type III waste storage tanks were developed in the early 1960s after: (1) investigation showed the primary cause for leaks in the Types I and II tanks was stress-corrosion cracks near the weld seams where residual stresses were high, and (2) large-scale tests on weld plates showed stress-relieving after welded fabrication should eliminate the stress-corrosion cracking. The specifications for the Type III design called for the following measures to minimize occurrence of stress cracking: (1) selection of ASTM A516-Grade 70 steel plate with a higher carbon content and higher yield strength, (2) minimization of stress risers and temporary weld attachments on the inner tank surfaces, and (3) finally a full stress-relief heat treatment at $1100^{\circ} \mathrm{F}$ of the as-fabricated tank in place.

Nitrate-induced SCC in mild carbon steel is caused by a combination of high stresses in the steel and the exposure of the steel to an aggressive nitrate environment, which is enhanced as the temperature increases. Given the right combination of steel stress, corrosive environment, and temperature, the result would be the initiation and propagation of a crack in the steel. Eliminate any one of these factors (stress, corrosive environment, or temperature) and the other two could not cause SCC.

\section{Waste Composition and Temperature Control}

Two of three necessary conditions for stress corrosion cracking, concentration of certain ions and temperature, are controlled in the waste tanks. Waste supernates are primarily alkaline nitrate solutions. Although either nitrate or caustic ions alone can cause stress cracking in mild steel, the presence of one inhibits cracking by the other. Also, nitrite, $\mathrm{NO}_{2}^{-}$, acts as an inhibitor to nitrate crack growth. The concentration of nitrite increases as waste ages since radiolytic decay promotes the production of nitrite from nitrate. Therefore, the waste solution contains ions that both cause and inhibit stress corrosion cracking of the mild steel tanks.

Laboratory studies, in which specimens were forced to crack by applied tensile loads, have led to an understanding of the conditions required for stress corrosion cracks to develop in the waste tanks, and provide a basis for controlling the waste compositions to avoid SCC. During most waste storage operations, technical standards require that the composition of the wastes is controlled as shown in Table A.1. SRL has recently performed additional corrosion tests to apply to processes involving in-tank precipitation and sludge washing; and new Technical Standards have been written. Some have been approved; others are routing for approval. Nitrates in the solid are in the stable salt form $\mathrm{NaNO}_{3}$ and are not ionized while nitrates in the sludge are exposed to high radiation and form nitrites. Therefore, the potentially most aggressive ion is nitrate in the

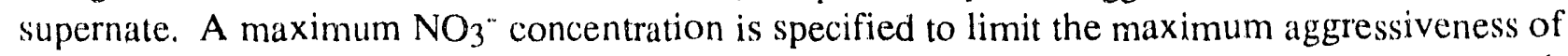
the supernate. The concentrations of inhibitors, $\mathrm{OH}$ - and $\mathrm{NO}_{2}$ - have been shown to prevent crack 
initiation even in highly stressed specimens. Experimental work was also completed by SRL to evaluate the effectiveness of present inhibitor concentrations on other aggressive anions in dilute solutions. This work was for improving the Technical Standards for dilute waste solutions, such as those stored in Type IV tanks.

\section{Table A.1. Required Minimum $\mathrm{OH}^{-}$and $\mathrm{NO}_{2}^{-}$Concentrations in SRS Wastes}

Concentration. $M$

$\mathrm{NO}_{3}^{-} \quad \mathrm{OH}_{-}^{-} \quad{\underline{\mathrm{OH}^{-}}+\mathrm{NO}_{2}^{-}-}^{-}$
$5.5-8.5$
0.6
$2.75-5.5$
0.3
1.1
$1-2.75$
$<1$
$0.1 \times\left[\mathrm{NO}_{3}\right]$
1.1
0.01
$0.4 \times\left[\mathrm{NO}_{3}\right]$

Transfers from the canyons must be made alkaline to be compatible with the mild steel waste tanks. Controls have been established in the canyons to provide the assurance that this is so.

The temperature of fresh supernate, containing the highest concentration of nitrates, is maintained at less than $70^{\circ} \mathrm{C}$. Stress corrosion cracking is a thermally susceptible process. Lower temperature inhibits the initiation and growth of cracks. The supernate temperature limit applies only to fresh waste because aged and concentrated (evaporated) wastes contain sufficient $\mathrm{OH}^{-}$and $\mathrm{NO}_{2}$ - to inhibit SCC at high temperatures. The greatest amount of decay heat is produced in fresh HHW sludge. To keep the supernate/sludge mixture at the tank wall from reaching the boiling point, heat is removed by circulating air through the tank annulus. The tank steel temperature is maintained at 10 degrees Centigrade less than the supernate boiling point, which is estimated from waste composition, specific gravity, and the hydrostatic pressure at the tank bottom. To confirm the accuracy of the estimated boiling point, experiments were conducted at the Du Pont Engineering Test Center (ETC) to deter- mine the boiling point of synthetic waste solutions at various pressures. An atmospheric boiling point, for waste supernate samples taken from fresh HHW receipt tanks in F/H Areas, was determined by SRL. The results from both SRL and ETC support the estimated boiling point.

Steel temperature control is affected by regulating the annulus airflows and by limiting the radioactive decay heat in any one tank.

Data from other laboratory studies conducted by SRL confirmed that A516-70 steel used in Type III waste Tanks 25-37 is less susceptible to cracking than the A285-B steel used in Types I and II tanks and that the supernates from salt receiver tanks are of the least aggressive compositions, while fresh wastes (high nitrate) are of the most aggressive ones. A537-I steel used in Tanks 38-51 has essentially the same composition and corrosion behavior as A516-70 steel. 


\section{Residual Stresses and Heat Treatment}

Besides an aggressive environment, the other necessary condition for SCC is the presence of tensile stresses in the metal. In large engineering structures, there are generally three types of stresses: (1) working stresses due to the external load the structure was designed to carry, (2) reaction stresses (long-range stresses due to fabrication), and (3) residual stresses (short-range stresses due to fabrication procedures such as welding and deformation to make parts fit together).

Working stresses in such structures have traditionally been designed to be low, about one-half or less of the yieid stress of the maturial in accordance with the ASME Boiler and Pressure Vessel Code; this is the case for the waste tanks.

Reaction stresses are difficult to estimate quantitatively. However, even though the waste tanks are large, they are simple structures, basically free-standing, right-circular vessels built on stable, reinforced concrete pads. Therefore, the reaction stresses in the tanks from such phenomena as settling should be low.

The tanks are made by welding individual preformed plates together. Since welding involves heating the metal to its melting point with subsequent cooling and solidification, contraction of the metal occurs in a localized, relatively small region. This thermal contraction is nonuniform and leads to built-in stresses that can exceed the yield stress of the material.

Cracks in the waste tanks have been predominantly associated with welds. Cracks form at right angles to the weld bead. They grow a short distance from the weld, then stop. The largest observed crack in a waste tank is eight inches long in Tank $16 \mathrm{H}$ which has been removed from service. Cracks stop growing as a result of the rapid decrease of the tensile stress with distance from the weld. These residual stresses can be relieved by uniformly heating a structure to a sufficiently high temperature $\left(\sim 11000^{\circ} \mathrm{F}\right.$ in mild steels) to allow the metal to relax because its strength decreases at elevated temperatures. Such treatment minimizes SCC by reducing the stress to low levels $\left(\sim 7000 \mathrm{lb} / \mathrm{in}^{2}\right)$.

\section{Waste Tank Usage}

Table A.2 shows current waste tank usage for $\mathrm{F} / \mathrm{H}$ Areas. Tanks with one or more known cracks in the primary vessel are indicated by *. Table A.3 shows total waste in'entory in the tanks annually since 1958 . 


\section{Table A.2. Waste Tank Usage}

$241-F$

Tank

$1-F^{*}$

?-F

3-F

4. F

$5-\mathrm{F}$

6-F

7-F

8-F

$17-\mathrm{F}$

$18-\mathrm{F}$

2()- $\mathrm{F}^{*}$

$25-\mathrm{F}$

26- F

$27-\mathrm{F}$

$28 \cdot \mathrm{F}$

$33-\mathrm{F}$

34-F

$44-\mathrm{F}$

45- $\mathrm{F}$

46. F

47. F
Usage

Inactive

Inactive

Inactive

Inactive

Inactive

Inactive

Inactive

Inactive

Inactive, waste removed

Inactive, waste essentially

removed, residual sludge remains

Inactive, waste removed

Concentrate receiver

Evaporator feed and LHW roceiver

Concentrate roceiver

Salt storage

HHW storage/receiver

HHW storage/recciver

Concentrate receiver

Concentrate receiver

Spare tank (emply)

Concentrate receiver
$241 \cdot \mathrm{H}$

Tank Usage

9- $\mathrm{H}^{*} \quad$ Salt storage

$10-\mathrm{H}^{*} \quad$ Salt storage

$11-\mathrm{H}^{*} \quad$ High-heat sludge storage

$12-\mathrm{H}^{*} \quad$ High-heat sludge storage

13- $\mathrm{H}^{*} \quad$ Evaporator feed, sludge storage

14- $\mathrm{H}^{*} \quad$ Sludge storage and salt storage

15- $\mathrm{H}^{*} \quad$ Sludge storage

16- $\mathrm{H}^{*} \quad$ HLW removed, tank interior cleaned, initial arnulus cleaning complete

21-H Waste removed, residual sludge remains, receives dilute radioaclive waste containing only $1-2 \%$ solids from $\mathrm{KBOF} / \mathrm{RRF}$ and wash water

22- $\mathrm{H} \quad$ Waste removed, residual sludge remains, receives dilute radioactive waste containing only $1-2 \%$ solids from RBOF/RRF and wash water

23-H Waste removed, residual sludge remains, receives dilute radioactive waste containing only $1-2 \%$ sclids from RBOF/RRF. Receives diverted and rocycled overheads from 242-H evaporator.

24-H Waste removed, residual sludge remains

29-H HHW concentrate receiver (inactive)

30-H HHW concentrate receiver

$31-\mathrm{H}$

32- $\mathrm{H}$

$35-\mathrm{H}$

$36-\mathrm{H}$

37- $\mathrm{H}$

38- $\mathrm{H}$

39. $\mathrm{H}$

$40-\mathrm{H}$

41-H

42. $\mathrm{H}$

$43-\mathrm{H}$

48-H

49-H

50-H HHW concentrate receiver (inactive)

HHW receiver/sludge storage HHW receiver/sludge storage HHW concentrale receiver (inactive) HHW concentrate receiver (inaclive) LHW concentrate recciver HHW receiver/sludge storage Sludge processing/DWPF sludge feed LLW concentrate receiver Sludge processing Evaporator feed and LHW receiver Salt processing tank for in-tank precipitation (salt decontamination) Salt processing tank for in-tank precipitation (precipitate recciver/ DWPF fecd tank)

Salt processing tank for in-lank precipitation (filterate recciver/saltstonc feed tarik)

51-H Sludge processing/DWPF sludge feed

* Has one or more known cracks in the prininary taink. 
Savannah River Site

Interim Waste Management

Program Plan--FY 1991-1992
Appendix III

Tank Construction and

Operating History

May 1992

Table A.3. High-Level Aqueous Waste Inventory (combined tank farms)

At End of Total

Fiscal Volume,*

Year $\quad 106 \mathrm{gal}$

1958

1959

1960

1961

1962

1963

1964

1965

1966

1967

1968

1969
6.9

8.0

9.9

13.6

14.3

15.7

16.2

14.2

17.5

16.9

17.0

17.4
At End of

Fiscal

Year

1970

1971

1972

1973

1974

1975

1976

1977

1978

1979

1980

1981

1982

1983

1984

1985

1986

1987

1988

1989

1990

1991
Volume, $10^{6} \mathrm{gal}$

Liquid Sludge Salt Total Reference

$\begin{array}{llll}10.6 & 2.1 & 5.1 & 17.8\end{array}$

$\begin{array}{llll}11.0 & 2.1 & 5.1 & 18.2\end{array}$

$\begin{array}{llll}10.6 & 2.1 & 5.6 & 18.3\end{array}$

$\begin{array}{llll}11.7 & 2.2 & 5.9 & 19.8\end{array}$

$\begin{array}{llll}11.8 & 2.0 & 6.5 & 20.3\end{array}$

$\begin{array}{llll}11.6 & 2.0 & 6.7 & 20.3\end{array}$

$\begin{array}{llll}12.0 & 2.1 & 7.0 & 21.0\end{array}$

$\begin{array}{llll}12.7 & 2.5 & 6.5 & 21.7\end{array}$

$\begin{array}{llll}12.3 & 2.6 & 7.2 & 22.1\end{array}$

$\begin{array}{llll}12.9 & 2.8 & 7.4 & 23.1\end{array}$

$\begin{array}{llll}16.8 & 2.8 & 6.8 & 26.6\end{array}$

$\begin{array}{llll}17.5 & 2.9 & 7.1 & 27.5\end{array}$

$\begin{array}{llll}19.7 & 3.2 & 7.7 & 30.6\end{array}$

$\begin{array}{llll}17.3 & 3.4 & 8.7 & 29.4\end{array}$

$\begin{array}{llll}20.1 & 3.6 & 8.6 & 32.3\end{array}$

$\begin{array}{llll}18.9 & 3.6 & 9.9 & 32.4\end{array}$

$\begin{array}{llll}19.2 & 3.6 & 10.9 & 33.7\end{array}$

$\begin{array}{llll}16.8 & 3.6 & 13.3 & 33.7\end{array}$

$\begin{array}{llll}15.9 & 3.8 & 14.1 & 33.8\end{array}$

$\begin{array}{llll}17.5 & 3.8 & 14.3 & 35.5\end{array}$

$\begin{array}{llll}16.3 & 3.8 & 14.7 & 34.8\end{array}$

$\begin{array}{llll}15.7 & 3.8 & 14.7 & 34.2\end{array}$
SR-TWM-76-1

SR-TWM-76-1

SR-TWM-76-1

SR-TWM-76-1

SRO-TWM-78-1, Vol. II

\footnotetext{
* Estimated volumes of sludge and salt were not routinely tabulated before 1970 .
} 


\section{Waste Transfer Systems}

The original concept of the Separations facilities relied primarily on steam-jet cductors and gravity for the transfer of radioactive liquids. The same concept was applied to the waste system, and all flow from the separations building to the tanks was by gravity. Valves were not used, so waste flow was directed to the appropriate tanks by a change of pipe jumpers in diversion boxes located near the tanks. All piping was fabricated of stainless steel. Secondary containment was provided by waterproofed concrete trenches which drained to leak collection and detection facilities.

The design of waste transfer lines has evolved from the original pipe-within-encasement system to a pipe-within-pipe system. Pipes within pipes were installed in 1969 for the transfer of unconcentrated waste between $\mathrm{F}$ and $\mathrm{H}$ Areas, a distance of two miles. This interarea line permits optimum use of the tanks and evaporators in both areas. Secondary containment pipes drain to a sump where any drainage can be sampled.

With construction of the Type II and subsequent H-Area tanks, which are at higher elevation than the original tanks to avoid a high water table, gravity flow of waste from the Separations building $(221-\mathrm{H})$ to the new tanks became impractical. Pump tanks with automatic, cantilevershaft, submerged centrifugal pumps were installed in concrete pits at a low point in the H-Area tank farm to boost the incoming waste up to the new tanks. Operating performance and service life of these pumps have been excellent.

Valve boxes are used to provide transfer routes for the waste transfer program. New valve boxes are being installed in several transfer lines in the F- and $\mathrm{H}$-Area tank farms.

The valve boxes on Tanks 40, 42, 49, and 51 tie together new above-grade transfer lines from these tanks with existing below-grade transfic lines and new flush water lines. The tanks 40, 49, and 51 valve boxes also tie in new transfer lines to the DWPF intermediate pump pits.

An underground interarea transfer pipeline is being provided for transfer of salt solution (about 9,150 feet long, 4-inches in diameter) to the saltstone facility in Z Area. The stainless steel line is jacketed for pipeline containment and leak detection purposes. The transfer line and jacket are continuously sloped from both ends toward a low-point drain tank which is in a concrete pit below grade.

Radioactive sludge will be sent to the sludge receipt and adjustment tank in the vitrification building in S Area and the precipitate feed will be sent to the precipitate reactor feed tank that is also in the vitrification building. Both will be batch transfers from the H-Area tank farm, via new interarea transfer lines which include an auxiliary pump tank and a low-point pump tank along the route. These facilities are being provided by the DWPF project. 
Savannah Hiver Site

Interim Waste Management

Appendix IV

Program Plan--FY 1991-1992

1991 Waste Reduction Report

May 1992

\section{APPENDIX IV}

\section{WASTE REDUCTION REPORT}


BLANK

IV -2

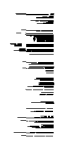


WER-SWM-92-0036

\section{DEPARTMENT OF ENERGY \\ SAVANNAH RIVER SITE \\ 1991 WASTE REDUCTION REPORT}

Westinghouse Savannah River Company

Savannah River Site

Aiken, SC 29808

PREPARED FOR THE U.S. DEPARTMENT OF ENERGY UNDER CONTRACT NO. DE-AC09-88SR18035 


\section{SAVANNAH RIVER SITE 1991 WASTE REDUCTION REPORT}

Approved:
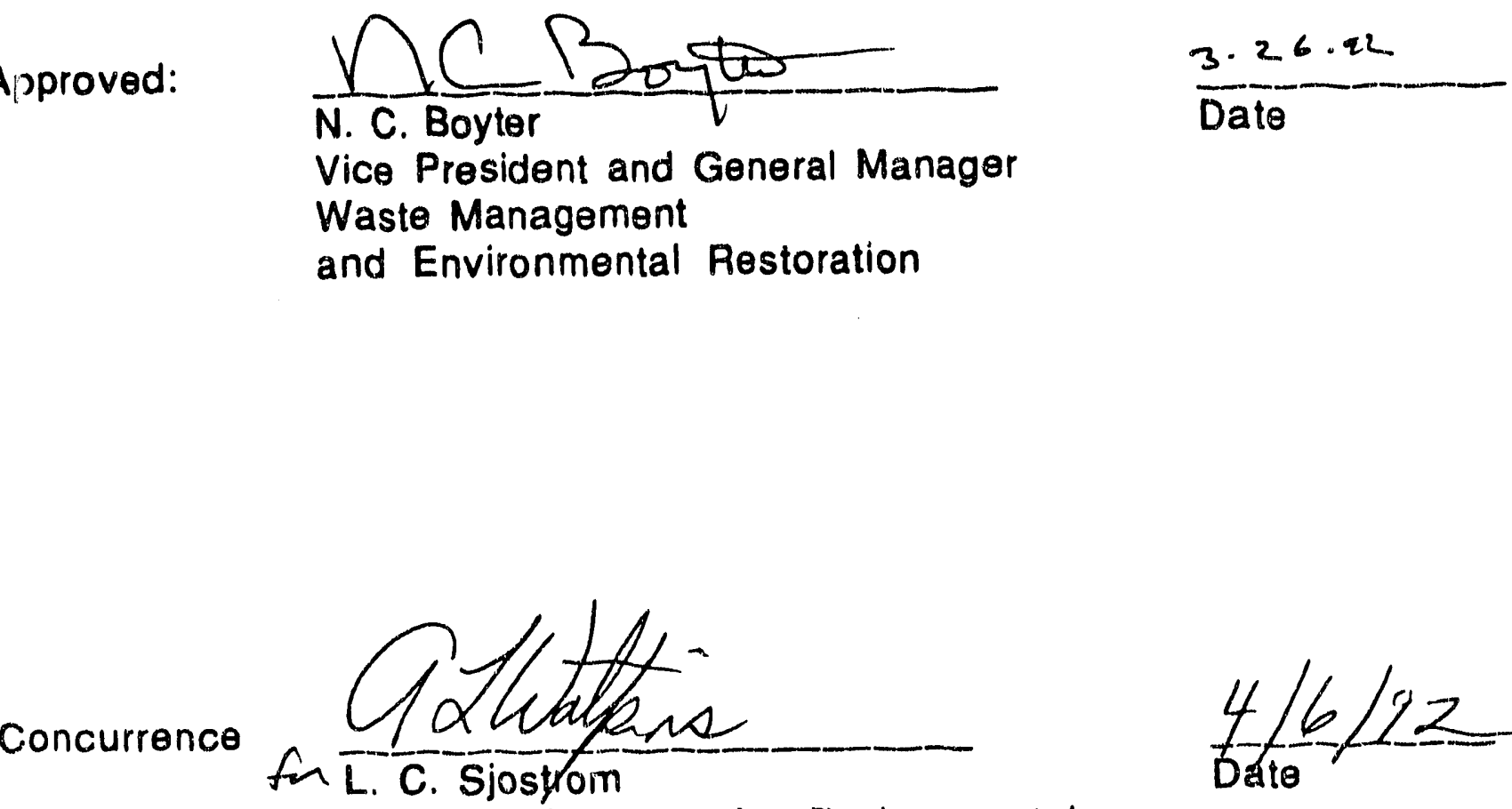

Assistant Manager for Environmental

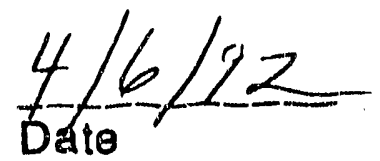
Restoration and Waste Management

Department of Energy

Savannah River Field Office 


\section{IABLE OF CONTENTS}

1. Program Administration

A. Structure of Waste Reduction Program

B. Organization and Responsibilities

1. DOE-SR

2. Site Contractor Management

3. Site Waste Minimization Group

4. Environmental Protection Department

5. Savannah River Laboratory

6. Waste Generating Organization

7. Waste Action Team

8. Waste Coordinators

C. Program Documeritation

D. Modifications to Program Administration

Page 1

Page 1

Page 2

Page 2

Page 2

Page 2

Page 3

Page 5

Page 3

Page 4

Page 5

Page 6

Page 7

Page 7

Page 7

Page 7

Page 7

Page 8

Page 8

Page 8

Page 9

Page 10

Page 11

Page 11

Page 11

Page 13

Page 13

Page 15

Page 16

Page 16

Page 16

Page 17

Page 17

Page 18

Page 18

Page 19

Page 19

Page 20

Page 20

Page 21

Page 21 
E Training, Awareness and Incentives

Page 22

1. Training

2. Awareness

Page 22

Page 22

3. Incentives

III. Program Performance

Page 25

A. Measure of Performance

Page 25

B. Reporting Performance Results

Page 25

1. Volume of Waste Generated

Page 25

2. Cost of Waste Generation

Page 26

3. Non-routine Waste

Page 27

4. Radionuclide Concentration

5. Environmental Restoration Waste

Appendix A Waste Reduction Hierarchy

Appendix B Waste Reduction Organization

Appendix C Programmatic Milestones

Appendix D Award Fee Criteria

Appendix E CY1992 Waste Assessment Schedule

Appendix $F$ Waste Generation Data

Appendix G SRS Solid Waste Forecast

Appendix $\mathrm{H}$ Cost Tables

Appendix 1

CY1991 Recycle Summary

Appendix $\mathrm{J}$ SRS Process Waste Assessment Schedule 


\section{ACRONYM LIST}

BSRI - Bechtel Savannah River Incorporated

CSRA - Central Savannah River Area

DETF - Dilute Effluent Treatment Facility

DOE - Department of Energy

EPA - Environmental Protection Agency

EPD - Environmental Protection Department

ERWM - Environmental Restoration and Waste Management

ESH\&QA - Environmental, Safety, Health, and Quality Assurance Division

FSWMP - Facility Specific Waste Minimization Plan

GOCO - Government Owned - Contractor Operated

HAZWRAP - Hazardous Waste Remedial Actions Program

HEPA - High Efficiency Particulate Air (filters)

LMF - Landfill Monitoring Facility

PWA - Process Waste Assessment

QISS - Quality Improvement Suggestion System

RCA - Radiologically Controlled Area

RCRA - Resource Conservation and Recovery Act

SCDHEC - South Carolina Department of Health and Environmental Control

SREL - Savannah River Ecology Laboratory

SRL - Savannah River Laboratory

SRS - Savannah River Site

SWMG - Site Waste Minimization Group

SWMP - Sita Waste Minimization Plan

USFS - United States Forest Service

WAC - Waste Acceptance Criteria

WAT - Waste Action Team

WM \& ER - Waste Management and Environmental Restoration Division

WSI - Wackenhut Services Incorporated

WSRC - Westinghouse Savannah River Company 
WER-SWM-92-0036

PAGE 1 of 27

\section{Program Administration}

\section{A. Structure of Waste Reduction Program}

The Savannah River Site Waste Reduction Program is an organized, comprehensive, and continual effort to systematically reduce waste generation. The Waste Reduction Program is designed to eliminate or minimize pollutant releases to all environmental media from all aspects of the Site's operations. The Site has set a high priority on solid waste as defined by the RCRA, but also addresses all other waste types. The program is carried out in an economical, practical and environmentally responsible manner. These efforts yield the following benefits:

- reduced waste management and regulatory compliance costs

- improved product yields

- reduced inventories and releases of hazardous chemicals

- energy conservation and reduced raw material costs

- natural resource conservation

- reduced civil and criminal liabilities under environmental laws

- reduced health and safety risks to employees and the public.

The program reflects the goals and policies for waste reduction at the SRS and represents an ongoing effort to incorporate waste reduction into the SRS operating philosophy. A hierarchical approach to waste reduction has been adopted and is applied to all types of waste (see Appendix A).

\section{B. Organization and Responsibilities}

The Site has established a st ucture to effectively support and implement the waste reduction programs as shown in Appendix B. WSRC has appointed the Vice President of WM\&ER as the senior management sponsor of the program to ensure that waste reduction receives proper management attention. The Site Waste Minimization group consists of a full-time manager and staff. This group has responsibility for coordinating the development, promotion, implementation, and reporting of the Waste Minimization Program and activities. A central WAT with representatives from the major operations, service, and staff groups has been established to develop strategy for and coordinate implementation of waste minimization program activities. Each of the major facilities has assigned one or more waste coordinators 
to lead the implementation of waste reduction activities in their specific areas.

\section{DOE-SB}

DOE:

- provides oversight and technical direction for the Waste Reduction Program

- transmits DOE orders, guidances, and direction relating to the Waste Reduction Program to WSRC

- provides authoritative judgements on the acceptability of procedures and facility documentation requirements relating to waste reduction

- prepares SR directives to clarify and supplement DOE orders where needed

- concurs with SRS Waste Minimization Plan and milestones

- transmits SRS Waste Minimization Plan to DOE-HQ

- provides funding for program activities

- supports implementation of the SRS Waste Minimization Plan by the assignment of priority to program initiatives.

\section{Site Contracter Management}

All WSRC division managers, and WSI, BSRI, SREL, USFS managers are responsible for supporting waste reduction by attempting to secure needed funds and appropriate levels of staffing and assigning representatives from their organization to the WAT.

3. Site Waste Minimization Group

The WSRC Site Waste Minimization Group (SWMG) is responsible for the development of the overall waste reduction program. This includes coordinating the development, promotion, implementing and reporting of the Waste Reduction Program and activities. Suecific esponsibilities are to:

- establish SRS waste minimization policy through the appropriate site managers

- develop, issue, and update as necessary (annualiy as a minimum), the SRS Site Waste Minimization Plan (SWMP) 
- perform waste reduction assessments of site waste generating departments on a rotating basis

- coordinate the development of SRS waste reduction goals

- issue monthly report on waste reduction status and activitios

- provide management feedback and guidance to the WAT

- solicit management support for waste reduction activities

- remain current on DOE and regulatory agency requirements and communicate these to the WAT

- issue internal site-wide waste minimization reports for DOE-SR and WSRC (WSRC EPD is responsible for all site reports to outside agencies)

- participate on the WAT

- provide assistance in resolving program conflicts

- coordinate waste minimization/waste reduction/pollution prevention with DOE, including audits and award-fee activities.

\section{Environmental Protection Department}

EPD:

- provides regulatory review and program oversight

- coordinates, prepare and submit official reports to regulatory agencies such as EPA and SCDHEC

- interprets regulatory requirements and communicates necessary actions to SRS personnel.

\section{Savannah River Laboratery}

SRL will provide the necessary research and development support to departments on such topics as process modifications, product/material substitutions, recycling technologies, decontamination technologies, treatment technologies, and appropriate technology transfer information.

\section{Waste Generating Organization}

Each person is responsible for minimizing the generation of waste in the performance of their work. Managers of a facility will strive to reduce waste generated, investigate and implement techniques/techrologies to reduce waste generation and track the waste that is generated. Typical managerial responsibilities are to: 
- develop, publish, implement, and maintain a current FSWMP (this plan will be reviewed annually and revised as necessary)

- assign personnel for waste reduction activities including WAT members and Waste Coordinators

- perform periodic (annua!ly as a minimum) waste reduction program self-assessments

- identify and characterize all waste streams with sufficient accuracy to ensure regulatory compliance and to allow proper minimization, segregation, treatment, storage, and disposal

- document activities as appropriate

- revise uperating procedures to reflect waste reduction techniques/methods and awareness, as appropriate

- develop and implement an effective process waste assessment program

- develop and maintain a method for evaluating waste generation performance and for forecasting waste generation for the facili'y

- establish and maintain waste generation as a facility performance incicator

- develop waste reduction goals and milestones and track progress

- develop budgets and obtain funding for waste reduction activities

- incorporate research and development initatives for waste reduction in facility programs as appropriate

- indoctrinate facility personnel in waste reduction awareness and techniques/methods

- assure waste reduction concepts are incorporated in process modifications and new installations

- recommend personnel for achievement and incentive awards

- assure waste reduction is considered in maintenance and decommissioning activities.

\section{Waste Action Team}

Each site organization, including supnort and staff groups, which has a significant impact on the generation, handling, storage, or treatment of any waste type is represented on the WAT. Typically, responsibilities of this team are to:

- review and concur with SWMP and program objectives

- develop SRS implementation strategies 
- coordinate and promote SRS waste reduction programs

- develop SRS procedures and systems applicable to waste reduction for management approval

- promote employee awareness programs

- promote employee training

- identify opportunities for waste reduction including research program opportunities

- facilitate technology and program information transfer

- promote employee involvement

- support Waste Coordinators.

Specific responsibilities of each team member are to:

- represent interests of their respective organization/area

- coordinate the waste reduction program within their respective organization/area

- solicit management support at the organization/department level

- submit activity information to the SWMG for monthly reports.

Many of the activities of the WAT are accomplished through subcommittees. These subcommittees are task oriented and are dissolved when their assigned task is completed. Current subcommittees include:

- Recycle Subcommittee

- Training Development Subcommittee

- Waste Minimization Media Subcommittee

- Resource and Material Review Subcommittee.

\section{Waste Coordinators}

Each facility that generates, handles, stores, or treats waste should have one or more individuals designated as waste coordinators to support each facility manager in developing and maintaining the waste minimization program. Responsibilities typically are to:

- serve as contact point for all facility waste issues

- maintain and evaluate waste generaiıon records

- identify opportunities for waste reduction

- coordinate and maintain waste stream identification and characterization data 
- coordinate the develepment of facility training/awareness program

- coordinate the establishment of waste reduction goals and monitor progress

- act as liaison for information exchange to facility

- promote employee awareness and involvement in waste reduction activities

- submit activity information to the SWMG for monthly reports

- coordinate facility waste reduction activities including: coordination with WAT and EPD.

\section{Program Documentation}

The Policy Manual is the highest tier of the SRS document hierarchy. The "Environmental Assurance Policy" (Section MP4.1, Rov. 2) establishes the waste reduction responsibilities of SRS organizations.

The SRS Waste Minimization Plan, Revision 4, is the primary documentation for the Site's Waste Reduction Program. This plan contains the SRS Waste Reduction policy, strategy, objectives, milestone goals, budget, organization, etc. It is reviewed and updated annually and approved by the staff of the managing contractor and the DOE field office. Appendix C contains the 1991 milestone goals, their status, and the 1992 milestone goals.

Thirty-two FSWMPS were written in 1991 (Twenty-eight have been revised as of 3/92). Each facility or group of facilities (as defined by each organization) which generates hazardous, radioactive, mixed or industrial waste with a total life cycle cost in excess of $\$ 100,000 / y r$. and service organizations significantly impacting the Site Waste Reduction Program prepares a FSWMP. These plans focus on the facility specific waste minimization program and goals. These plans are reviewed annually and revised as necessary by facility management.

The SWMG publishes a monthly report which documents the waste generated (Low Level Waste, Intermediate I evel Waste, High Level, TRU, Mixed, Non-Radioactive Hazardous and Industrial wastes) during the month along with a description of the waste reduction activities that have occurred in each department or facility. Performance indicators are also published in the monthly report. 
The waste reduction program is evaluated and the performance documented every six months for the award fee criteria. During each award fee period a list of performance criteria and performance indicators are given to WSRC. WSRC responds with an Action Plan and deliverables for each performance indicator. Appendix $D$ is the Award Fee criteria for Periods 4, 5, and 6 covering the period 10/90-3/92. The Award Fee items are reviewed for progress bimonthly by the Performance Evaluation Committee (PEC).

\section{Modifications To Program Administration}

During 1991, the WSRC Waste Reduction Program underwent significant improvements. The SWMG expanded from five to eight people. The organizational structure of the SWMG now centers around waste types with managers assigned responsibility for reduction programs for individual waste types.

Position descriptions were developed and approved for the SWMG. The group's organizational structure and position titles are shown in Appendix B.

\section{Program Description}

\section{A. Waste Minimization Assessments}

\section{Appraisal Program}

Evaluation of the SRS Waste Reduction Program is conducted using a hierarchical system of appraisals/audits. The system is based on self-appraisals by each waste generation facility, organization, department, or division. These self-assessments are followed by increasingly higher level and broader appraisals by independent parties. Responsibility for, and scopes of, appraisals follow:

\section{a. Internal Appraisals}

The FSWMPs include a formal, documented internal appraisal system, preferably implemented through their Quality Assurance organization. These appraisals assure that:

- appropriate facilities or groups have current, authorized FSWMPs 
- each FSWMP satisfies current regulations, DOE directives, and Site and DOE guidance

- implementation of the FSWMP is effective and on schedule

- each FSWMP is reviewed at least annually and updated as appropriate.

b. WSRC Appraisals

The ESH\&QA Division coordinates independent oversight of the SRS waste reduction program and implementation of the program at the organization/division level. These appraisals are held at least every three years. These appraisals assure that:

- the SRS program (including the FSWMP, WAT activities, and the SWMG initiatives) satisfies current regulations and DOE directives

- implementation of the SRS plan is effective and on schedule

- facility specific waste minimization appraisal programs are effective and being implemented.

c. DQE-SB Audits

The DOE provides program oversight and direction for the overall waste reduction program at SRS. Audits, coordinated through WSRC ESH\&QA, assure that the:

- Site program, including the WSRC oversight program, satisfies current regulations and DOE directives

- Site waste reduction program is being implemented and is effectively meeting DOE expectations.

d. Qther Oversight Functions

Foilowing are other oversight functions to be carried out in addition to the formal appraisal programs described above.

- ESH\&QA coordinates a surveillance program that enlists WSRC environmental professionals to monitor and observe environmental activities and evaluate their adequacy and effectiveness, including waste reduction activities. 
- The Site Waste Minimization Group condusts monthly assessments of a waste generator to help identify opportunities for improvement and to assist in program implementation.

- DOE-SR Waste Operations and Technical Division conducts surveillances of specific activities and/or facilities to assure effective program implementation.

- Each facility conducts waste reduction walk-throughs as appropriate to assure effective program awareness and implementation.

\section{Aporaisal Results}

In CY1991, DOE-SR conducted two environmental appraisals and transmitted the results of another appraisal conducteo in CY1990. These audits and their results are listed below:

DOE-SR Audit of WSRC's Low Level Radioactive Waste Audit Dates: October 15 to October 26, 1990 Results: 3 Findings

DOE-SR Environmental Appraisal Report Hazardous/Nonhazardous Waste Minimization Program Appraisal

Appraisal Dates: June 12 - June 26, 1991

Final Report Date: September 24, 1991

Appraisals Results: 7 findings

3 observations

DOE-SR Environmental Appraisal Report - SRS Recycle Program Environmental Appraisal

Appraisal Dates: August 14 - October 1, 1991

Final Report: November, 1991

Appraisals Results: $\quad 4$ Noteworthy Practices

2 Recommendations

2 Category III Deficiencies

5 Category IV Deficiencies

The Site Waste Minimization Group performs monthly programmatic and walk-through assessments of waste generators across the site on a rotating basis. The recommendations from the assessments are transmitted to the 
generators in a written report. The following areas were assessed in 1991:

\section{Month}

January

February

March

April

May

June

July

August

September

October

November

December

\section{Eaclility}

F-Canyon/OF (Separations)

P-Reactor (Reactor)

$\mathrm{H}$-Tank Farm (WM)

H-Canyon/HBL (Separations)

Tritium

Reactor Materials

ETF (Waste Management)

235-F (Separations)

ITP (Waste Management)

FBL. (Separations)

772-F Laboratory

SRL

The evaluations focused on compliance with FSWMPs, waste minimization techniques and good practices. Following are some of the major items that were reviewed: controlling access to B-25 boxes, segregating waste at the point of generation, procedure modification, usage of 12 mil bags in place of cardboard boxes, the internal audit program, unpackaging supplies before entering an RCA, schedule for process waste assessments, reducing the RCA size as much as possibie, personnel training, and the completion and utilization of the FSWMP.

Appendix $E$ gives the schedule for assessments to be completed in 1992. The assessments have served an important role in the information exchange across the site, providing guidance to the generators, as well as documenting the status of the waste reduction program.

3. Process Waste Assessments

The Site developed a formal Process Waste Assessment (PWA) program during CY1991. This program defines requirements, schedules, PWA team composition, reports, review, oversight and follow-up. This prograrn was communicated to all waste generating organizations.

Key elements of the PWA program are: 
WER-SWM-92-0036

PAGE 11 of 27

- PWAs to begin in CY1992

- PWAs for processes generating life cycle waste costs in excess of $\$ 500,000 / y r$. will be completed by December 31 , 1994

- PWAs for processes generating life cycle waste costs greater than $\$ 100,000 / y$. will be completed by December 31 , 1998

- PWAs will be reviewed every 5 years for processes with life cycle waste costs greater than $\$ 100,000 / y$ r.

During CY 1991, one PWA was conducted on the low level radioactive waste stream (solid waste) from the $H$ Canyon, Building 221-H. The PWA team consisted of operations, technical, works engineering, and other facility employees. Lessons learned from this pilot PWA are being incorporated into the Site's PWA program and training. This PWA took 6 man-months of effort at an estimated labor cost of $\$ 50,000$. Twenty-three recommendations were produced and are currently being implemented and tracked by facility management.

Appendix $\mathrm{J}$ contains the current schedule for PWAs at the SRS.

\section{B. Waste Reduction Operating Experiences and Successes}

1. Source Reduction

a. Radioactive Waste (LLW)

- Most of the site uses 12 mil plastic bags to discard radioactive waste into a $\mathrm{B}-25$ box. Using plastic bags instead of cardboard boxes allows 50 to $70 \%$ more waste to be placed into the B-25 box. Along with the utilization of the plastic bags, several of the facilities are utilizing lexan boxes to hold the plastic bags instead of cardboard boxes. This eliminates the eventual disposal of the cardboard box as radioactive waste.

- The Site instituted administrative controls of low level waste containers in all areas to prevent the mixing of waste types. This control prevents or minimizes nonradioactive waste from entering a radioactive waste stream. 
- Depackaging of equipment and materials before entering RCAs was instituted by most facilities on the site. This technique prevents the packing material from being introduced into the low level waste stream.

- The SRS reduced the size of RCAs by 173,500 square feet. A reduction in the RCA size reduces the area in which radioactive and mixed wastes are produced, thus minimizing waste generation.

- Plastic and metal pallets that can be decontaminated are being evaluated as a substitute for wooden pailets in selected RCA areas. Not only are these pallets reusable, but they also make any wooden pallets brought into the facilities very noticeable. These pallets eliminated the use and contamination of over 400 wooden pallets in the canyon facilities.

- FB-Line instituted a comprehensive waste minimization program including: the use of waste tags on all waste, 12 mil plastic bags instead of cardboard boxes, the assignment of waste operators on each shift, and greatly increased use of the low level waste compactor. The facility also provided waste minimization iraining to all employees and included waste minimization in their job procedures. Through this combination of efforts, FB-Line was able to decrease its low level waste generation from an average of over 150 B-25 boxes ( 3 cubic meters each) per month to an average of 16 B-25 boxes per month.

- Equipment has been procured for evaluating carbon dioxide pellet decontamination blasting and decontaminating foam. Both of these methods will significantly reduce waste in decontarnination operati...

- F-Tank Farm and H-Tank Farm (Waste Management Facilities) continued use of lexan step off pads instead of paper in the RCA reducing the amount of radioactive waste generated.

- Several facilities began using a polyester wiping cloth for decontamination. This polyester wipe generates about $50 \%$ less waste than the conventional atomic wipe. 
- The process piping and software of the Saltstone Mixing and Transfer System was modified to permit flushing with salt solution, which is the low-level radioactive waste that is processed in the Saltstone Facility. The flush solution removes any grout remaining on the surfaces of the process equipment at the end of each day's operation and is stored in the Flush Water Receipt Tank for recycle into the process during the next operation of the system. Process water was previously used for this purpose and generated additional waste volume to be processed. A smaller volume of process water is still used to make a final flush of the pumps used to transfer the grout from the process room to the disposal vaults. This waste minimization technique results in a reduction of 1.5 million liters of grout annually and has a projected economic savings of $\$ 1$ million in Z-Area operating funds per year including the cost of vault construction.

\section{b. Radioactive Waste (TRU)}

SRL is investigating an electropolishing technology using nitric acid based electrolyte. The method will be used to decontaminate the Separations canyon vessels. This method will generate $1 / 10$ the volume of radioactive waste compared to the present methods. The process was reviewed and verified by consultants in February, 1991, and is awaiting funding to be implemented.

c. Radioactive Waste (Mixed)

- Reactor Materials Department reduced the amount of filter cake produced in the DETF supernate processing operation by $50 \%$ ( 182,000 liters). This was accomplished by optimizing the filter aid particulate size and then reducing the amount of filter aid by $42 \%$ while still maintaining filtrate quality. This also resulted in an $8 \%(500 \mathrm{kgs}$.) reduction in filter media. This filter cake and filter media are currently classified as a mixed waste since they contain an F006 hazardous waste. Another factor in the success of the above-mentioned process is the implementation of the Pollutech Preston K144L polymer system, which increases fitter cake 
thickness. Filtration times have also been increased, which also increased the volume of water through the filter. The polymer has decreased the usage of filter media by a factor of 4.5 , resulting in a $\$ 370,000$ savings in final disposal cost for the filter paper.

- Most facilities at the SRS made extensive use of nonhazardous substitutes for F-listed solvents utilized for decontamination. By removing the hazardous constituent, the rags used for decontamination are handled as low level versus mixed waste. This material substitution contributed to the significant reduction in radioactive mixed waste shown in Appendix $F$.

- SRL is running pilot studies on utilizing electropolished stainless steel bricks as a substitute for lead bricks in radioactive shielding.

- The Separations facilities have replaced the lead counterweights used on jumper pipes with stainless steel. The new counterweights will be disposed of as radioactive waste. This will eliminate 42 cubic meters of mixed waste per year.

- The Reactor areas have replaced the cadmium plated frames of high efficiency particulate air (HEPA) filters with stainless steel. The old cadmium filters were dismantled, separating the cadmium plated frames from the filter media. The cadmium frames were handled as mixed waste and the filter media was compacted and disposed of as radioactive waste. Using stainless steel instead of cadmium, coupled with compaction, 64 filters can be placed in 2 B-25 boxes ( 3 cubic meters each). The old disposal method would require $10 \mathrm{~B}-25$ boxes for 64 filters and would be classified as mixed waste. The new filters fabricated with stainless steel will be disposed of as low level waste instead of mixed waste.

- The Laboratories Department implemented and completed a program to evaluate the need for lead lined gloves in glove boxes throughout the laboratories. The study revealed that $75 \%$ of the lead lined gloves can and will be replaced with non-leaded gloves. This will eliminate the generation of a mixed waste. 


\section{d. Hazardous (Nonradioactive)}

- The SRS started a "blue dot" program where hazardous chemicals are labeled with a blue dot upon receipt. This program is designed to minimize the use of hazardous chemicals through awareness. It is also designed to encourage the proper handling and disposal of these chemicals.

- Several facilities have substituted non-hazardous solvents for F-listed solvents in degreasing operations. The Construction department eliminated 5 cubic meters of hazardous solvent rags/wipes through such substitutions.

- A heating process is being evaluated that would eliminate solvent degreasing in the Reactor Materials production area. This has the potential to eliminate the use of 13,000 kgs. of Trichloroethylene per year.

- Health Protection (HP) began using Ecolite, a nonhazardous substitute for Atomlight, in processing samples. This new solvent eliminated $4,2.00$ liters of hazardous waste generated per year.

- The non-radioactive lead melter filtration system has been modified to reduce the quantity of particulates that reaches the filter media. This modification minimizes the amount of air drawn through the filters and included the installation of Baffle Plates and pre-filters to trap larger particles. This increases the operating life of the filter media and reduced the number of lead filters which have to be disposed of as hazardous waste.

- The DWPF laboratory instituted procedural changes that allowed the acetonitrile addition rate to samples be reduced from $1.5 \mathrm{ml} / \mathrm{min}$ to $0.3 \mathrm{ml} / \mathrm{min}$. This resulted in an $80 \%$ reduction in acetonitrile waste totaling a 400 liter/year reduction in.nonradioactive, hazardous waste. 


\section{Recycling}

a. Hazardous Waste (Nonradioactive)

- Currently excess and scrap lead, including pre-molded shapes, counter-weights, and washers is collected from various areas throughout the site, me!ted down and shaped into shielding for use in radiological areas in lieu of disposal. Construction recycled 10,000 kilograms: of lead in 1991.

- Solvent rags used for degreasing in Construction shops are collected and reused as long as practical. This has reduced hazarcous waste generation from 16.4 cubic meters to 3.8 cubic meters.

- The SRS purchased five small portable distillation units to recycle spent paint solvents. Two units have installed and permitted to date. These units reduced the volume of waste and time required to handle and transport the waste. The Site recycled 770 liters of paint solvent in CY1991. SCDHEC permits are required for the other 3 units.

- Freon generated on site is recycled by utilizing it as a decontamination solution for decontaminating the cranes located in the Separations canyon buildings.

b. Clean Waste

- The SRS purchased a system to recycle used antifreeze by mechanical filtration and chemical treatment. This process does not generate any hazardous wastes. SRS recycled 14,000 liters of antifreeze in 1991.

- A lathe coolant recycle unit has been procured to extend the life of metal working fluid. The unit will provide an efficient process for removing oil and other contaminants from the water based fluid. Through the process of pasteurization and coalescence, the module will control bacteria and remove tramp oil to a storage drum. The collected oil will be mixed with other used oils and burned at the site's power house for energy recovery. SRS 
collected 14,000 liters of lathe coolant in 1991. The unit is expected to be installed and operable in 1992.

- Used oil is generated on site and burned for energy recovery in two on site powerhouse boilers. The used oil generated includes lubricating, transformer, gearbox, diese and fuel oils. Burning used oil provides a clean fuel source for steam generation. An estimated total of 212,000 liters of used oil was processed in CY1991.:

- The SRS operates an extensive recycle and salvage operation. Appendix 1 details the items and quantities that were recycled/sold in CY1991.

\section{Ireatmens}

\section{a. Radioactive Waste}

- SRL decontaminated lab gloves to enable the generator to dispose of the gloves as low level radioactive waste instead of TRU waste.

- SRL is investigating a technique to wash soil to remove contaminants. If the technology is proven, soil can be segregated into a radioactive portion and a clean portion, then disposed of as required.

- The Effluent Treatment Facility treated 75,000,000 liters of water resulting in 74,200,000 liters being released as clean water. This process treats large quantities of low level liquid waste to remove contaminants then discharges the effluent as "clean" water to a permitted outfall. Release limits are presented in Section II.D.

- The Landfill Monitor Facility is a facility utilized as a final check to ensure that the contents of a container are not radioactive. The containers are twenty-one inch cardboard boxes. These boxes originate in an ACA; and, therefore, must be assayed to ensure the contents are "clean". A total of 5,700 boxes were assayed at the facility. Of the 5,700 assayed, 3,900 boxes were released to the on-site sanitary landfill and the remaining boxes were shipped to the on-site low level 
radioactive waste compactor. The boxes released to the sanitary landfill saved approximately 100 cubic meters of radioactive Solid Waste Disposal Facility space.

- The SRS has two low level radioactive waste compactors. These compactors processed approximately 6,400 cubic meters of low level radioactive waste in CY1991. This activity saved approximately 5,500 cubic meters of Burial Ground space. Compaction of containerized law lavel waste increased from $25 \%$ in CY 1990 to $40 \%$ in CY1991.

- The site has two evaporators which reduce the volume of waste in the high level radioactive waste tanks. During 1991, a total of $6,815,000$ liters of space was saved in the Tank Farms by operation of these evaporators.

b. Mixed Waste

- The M-Area Dilute Effluent Treatment Facility (DETF) reprocesses supernate from the Interim Treatment and Storage Facility reducing the volume of mixed waste by $68 \%$. This will res'slt in a savings of over $\$ 20$ million in final disposal costs.

- Separations Department and Construction have developed and fabricated a device for puncturing empty spray cans which contained a hazardous material. This permits the cans to be disposed as LLW, thereby, reducing the amount of mixad waste generated in the Separations Department by 3 cubic meters per year.

c. Clean Waste

- WSRC has submitted a proposal to SCDHEC to enable the SRS to bioremediate soil contaminated with petroleum products. This material cannot be placed in a sanitary landfill if the total petroleum hydrocarbons (TPH) in the soil is over $100 \mathrm{ppm}$. A presentation was made to SCDHEC late in the year to educate SCDHEC on the Site's intention and to obtain guidance on approvals needed to develop a pilot facility on site. WSRC has not received any formal response from SCDHEC. 


\section{Problems Encountered}

Some of the problems that have been encountered while reducing waste generation are listed below:

- Obtaining direction from SCDHEC on what is required to construct and operate a facility to bioremediate soil contaminated with petroleum products and what will be required to operate a compost facility.

- Obtaining direction from SCDHEC on what is required to construct and operate a compost facility.

- Obtaining permits from SCDHEC to operate the two small solvent reprocessing stills. The units were on site over six months before receiving permit approval. SCDHEC permits are outstanding for 3 additional units.

\section{Waste Reduction Budget and Accomplishments}

The waste reduction budget at the SRS supports the SWMG and the WAT in developing and promoting pollution prevention programs throughout the site. Activities specific to each operating area/facility are funded within that area/facility. This is consistent with the SRS philosophy to make the generators responsible for the costs of their waste. The SRS budget for FY1991 was developed before the formation of the SWMG and waste minimization activities were not itemized. The budget for FY1992 is summarized as follows:

FY1992

( $\$$ in thousands)

CLS Labor

Subcontracts

Engineering Service Requests

Direct Materials

Other

Total
773.2

90.0

36.0

$\$ 1,138.0$

The actual implementation of waste minimization concepts and practices is accomplished within the waste generating organizations where waste minimization is currently not tracked as a separate budget activity. 
If waste reduction efforts had been fully funded and staffed at Savannah River in CY1991, the following would have been possible:

- Full staffing of the Site Waste Minimization Group. This would have provided an individual manager for each major waste category (hazardous, high level radioactive, low level radioactive, transuranic, radioactive mixed and sanitary) to promote awareness, training, technical assistance, plans, : procedures, assessments, source reduction, recycling, and treatment.

- The initiation and acceleration of the PWA program. The results of these assessments will provide a basis for waste reduction program arlalysis. The assessments will also provide a more comprehensive, prioritized list of waste reduction opportunities for each facility.

- The assignment of personnel in all waste generating facilities to promote, monitor, train, write and review procedures, conduct PWAs and other activities to improve waste reduction.

- Recycling programs could have been expanded to include glass, plastic, paper, cardboard, and photographic silver.

- Electronic mail capabilities could have been expanded to allow more paper'ess communicationis.

\section{Background Radiation Segregation Limits}

The following criteria are used by SRS to segregate the various types of waste:

1. Radioactive Wiste

- Low-level waste is segregated based on radiation rates to facilitate safe handling. Intermediate-level waste is the SRS designation for the higher activity fraction of low-level waste. Waste radiating $>200 \mathrm{mrems} / \mathrm{hr}$ at $5 \mathrm{~cm}$ is categorized as intermediate-level. Savannah River Laboratory studies indicate that this is typically equivalent to higher activity Class " $A$ " waste and Class " $B$ " waste if the NRC waste classification system is applied to SRS generated waste. 
WER-SWM-92-0036

PAGE 21 of 27

- Transuranic contaminated waste is segregated from the standard low-level waste stream. Transuranic waste (TRU) is waste contaminated with $>100$ nanocuries of transuranic radionuclides per gram of waste. This material is being stored until processed for shipment to the Waste Isolation Pilot Plant (WIPP). Waste contarninated with $10-100$ nanocuries transuranic radionuclides per gram of waste is being packaged and stored in a similar manner as TRU waste until site specific radiological performance assessments are compieted and disposal options are evaluated.

\section{Cloan Solid}

"Clean" waste is non-contaminated waste with a potential for contamination from Site activities due to its origination in a Radiologically Controlled Area (RCA). Release of this waste to non-radiologically controlled areas is based on one of the following criteria: a) all potentially contaminated surfaces are $<10 \mathrm{dpm} / 100 \mathrm{~cm}^{2}$ alpha, $<80 \mathrm{dpm} / 100 \mathrm{~cm}^{2}$ beta-gamma, and $<450 \mathrm{dpm} / 100 \mathrm{~cm}^{2}$ tritium, or b) the generator participates in the "Clean" waste program. This program allows generators of waste potentially contaminated with gamma emitting radionuclides to implement administrative controls and segregate noncontaminated waste from within a RCA. This bulk waste is packaged in 21-inch cubed cardboard box, surveyed by Health Protection, and sent to the Landfill Monitoring Facility (LMF), 9 box assay facility, to verify the waste contains no SRS induced radionuclides. "Clean" waste reading $<10$ nanocuries per 21 inch box at the LMF is disposed of onsite in a designated area of the sanitary landfill.

3. Clean Liquid

Water is monitoring and released if the total gross beta and gamma reading is less than 10 disintegrations per minute per milliliter $(\mathrm{dpm} / \mathrm{mll})$ and the alpha level is less than $3 \mathrm{dpm} / \mathrm{ml}$. 
WER-SWM-92-0036

PAGE 22 of 27

\section{E. Training, Awareness, and incentives}

\section{Iraining}

One of the important elements of the Waste Reduction Program is training. The training/orientation program includes all SRS personnel as appropriate. The goal of this program is to build cominitment in each employee to incorporate waste reduction into all of his/her work activities. This is done by making:each employee aware of waste generation, its impact on the SRS and the environment, and ways waste can be reduced.

Waste reduction principles have bren incorporated into the new employee orientation programs. Waste reduction techniques have also been included in the Radiation Worker Core Training, given to all employees who work in a RCA. Site level training, where appropriate, continues to incorporate waste reduction concepts. Additional training courses to be developed and delivered in CY 1992 include PWA training, WAT Training, Waste Coordinators Training and a Waste Minimization Design Course.

It is the responsibility of each organization to provide adequate training and/or orientation on waste reduction policies, procedures and techniques to its personnel.

\section{Awareness}

Awareness is a key element of the Site Waste Reduction Program. The program includes the following elements:

- communication of the need for, and benefits to be derived from, waste reduction

- contributions each employee can make to an improved working and living environment through waste reduction

- management commitment to waste reduction

- overview of policy and regulations

- improved operating practices for reducing waste generation

- solicitation of waste reduction ideas and the discussion of waste reduction opportunities

- overview of waste reduction programs and identification of contact personnel.

CY1991 activities to increase employee awareness were: 
- 5 articles in local public newspapers

- 21 articles in the site newspaper and departmental publications

- 10 items in Electronic Mail on waste reduction concepts

- Poster and sign displays in facilities/areas

- Monthly reports - waste minimization monthly reports

- Training (e.g. 3 Waste Minimization Workshops with approximately 100 managers attending)

- 8 segments of the monthly SRS Video Magazine

- Weekly and monthly newsletters

- Bechtel Savannah River, Inc. Update (weekly)

- Environmental Protection Division Environmental Exchange (monthly)

- Environmental awareness activities include participation in:

- Energy Awareness Day

- Technical Day

- Environmental Awareness Day

- CSRA Earth Day

- Monthly WAT and Waste Coordinators Meetings

These activities and others will be continued in the future.

The Pollution Prevention Awareness Program required by DOE Order 5400.1 has been incorporated into the Waste Reduction Program.

The purpose of the Pollution Prevention Awareness Program is to foster the philosophy that prevention is superior to remediation. The goal of the program is to incorporate pollution prevention into the decision-making process at every level throughout the organization.

The Pollution Prevention Awareness Program has the following objectives:

- make employees aware of general environmental activities and hazards at SRS

- make employees aware of waste minimization program requirements, goals, and accomplishments

- inform employees of specific environmental issues

- indoctrinate employees on their responsibilities in pollution prevention 
- recognize employees for efforts to improve environmental conditions through pollution prevention

- encourage employees to participate in pollution prevention

- publicize success stories.

Three sessions of the Pollution Prevention Workshop for managers, developed by HAZWRAP, were conducted at the SRS during 1991 and more are planned for 1992.

\section{Incentives}

Award programs are used to recognize individuals and teams who display outstanding efforts in waste reduction and pollution prevention.

The Quality Improvernent Suggestion System (QISS) program is being utilized to promote waste reduction. The QISS program encourages employees to submit ideas that will improve quality in safety, security, waste reduction, environmental protection, health protection, energy conservation, and/or other work related product or process. Employees receive a $\$ 50.00 \mathrm{U}$. S. Savings Bond and $\$ 10.00$ cash, or $\$ 35.00$ cash, for each suggestion approved. Any employee of WSRC or BSRI may submit a QISS. During CY1991, 597 QISS suggestions were approved for waste reduction with a documented savings of $\$ 2.7$ million.

Other award programs utilized include Total Quality Achievement Award, George Westinghouse Signature Award, as well as the Westinghouse Service Awards.

Another incentive program for WSRC/BSRI is the award fee program. Waste minimization has been included as part of the award fee criteria. WSRC has received a rating of "Good" for the waste minimization portion of the award fee during periods 4 and 5 (covering CY1991).

Site waste reduction goals have been incorporated into performance indicators and are reported monthly in the Site Waste Minimization monthly report. Each facility that has a Site Waste Minimization Plan includes waste generation as part of their facility performance indicators. 
WEE-SWM-92-0036

PAGE 25 of 27

\section{Program Performance}

\section{A. Measure of Performance}

The Waste Reduction Program performance for 1991 was measured by the reduction in the total amount of waste generated during the year as compared to CY1990. Appendices F and G present the SRS goals and the performance for CY1991 by each waste category.

No goal was set in sanitary and high level radioactive waste. There was not enough historical information on sanitary waste to set a goal. Due to the uncertainty of reactor start-up and processing of off-site material in the canyon buildings, no goal was set for high level radioactive waste. The other goals were set by the solid waste forecast and are shown in Appendix $G$.

The CY1992 goals are to generate less waste, in all categories, than was generated in CY1991. This is an aggressive goal since the waste forecast for CY1992 is significantly higher than the actual waste volumes generated in CY1991.

The Site Waste Minimization monthly report provides the data in table form broken down by areas. The data for the current calendar year is compared to the previous calendar year. Appendix $F$ contains the summary graphs for the SRS performance in 1991.

\section{B. Reporting Performance Results}

\section{Volume of Waste Generated}

A significant reduction in the total amount of solid waste generated by the site was achieved in 1991 compared to 1990 while overall production, maintenance, and project activity remained relatively constant. This resulted in cost avoidance of over $\$ 40$ million based on waste life cycle cost for handling, storage, processing, and ultimate disposal. The difference in CY 1991 and CY 1990 waste generation is:

$31 \%$ increase in High Level Radioactive Waste (non-hazardous) $48 \%$ reduction in TRU Waste (non-hazardous) $96 \%$ reduction in Mixed Waste $58 \%$ reduction in Hazardous Waste (non-radioactive) $13 \%$ reduction in Low level Radioactive Waste (non-hazardous) 
Amounts measured are as received at Site storage/disposal facilities. Waste has historically been measured in volumetric units at the SRS. Investigation of methods to provide mass units is in the preliminary stages. The increase in high-level radioactive waste was due to an increase in production. A change in the regulatory interpretation of the mixed waste definition at the SRS resulted in a higher than normal mixed waste generation in CY1990. Therefore, the very large reduction in mixed waste should not be attributed only to: waste minimization efforts.

The reductions in the different waste categories are the result of the activities reported in Section 11 of this report. Training and awareness, among all the waste reduction activities, probably contributes more to waste reduction than any other activity. The direct correlation between training and awareness activities and waste reduction is impossible to establish. Also, since almost all waste at the SRS is the result of non-production line activities, correlating waste reduction results to any specific waste reduction method is very difficult, if not impossible, to establish. The waste reduction program at SRS is still developing and it is not possible at this time to baseline waste generation and waste reduction to any specific parameter or group of parameters.

The SRS has initiated a PWA program and a Waste Acceptance Criteria (WAC) Waste Certification program. Once the PWAS are performed and WAC program is fully implemented, the SRS should be able to develop a meaningful move basis for waste generation and waste reduction. Until a quantitative basis is available, knowledgeable individuals in waste generating racilities comment monthly on significant changes in waste generation. These comments are recorded in the SWMG monthly report.

\section{Cost of Waste Generation}

The SRS developed a life cycle cost for each waste type during CY1991. The total life cycle cost consists of the variable and fixed cosis associated with handling each waste type from generation through final disposal and monitoring. Fixed costs are associated with keeping facilities operating and are independent of the amount of waste handled. Variable costs are those costs associated with the packaging, handling, shipment, 
storage, treatment, disposal and monitoring of each unit of waste (See Appendix H). The life cycle cost numbers are being reviewed and updated for CY1992. This effort is being coordinated with other Westinghouse GOCOs to bring uniformity to the approach.

3. Nen-Routine Waste

The SRS does not segregate its waste into routine and nonroutine categories. Therefore, specific information on the split of routine and non-routine waste is not available. As noted above, any significant variations in waste generation are noted on the monthly report. The largest single non-routine waste generation activity during CY1991 was contaminated and suspect contaminated soil generated as a result of the $1 \mathrm{H}$ evaporator project. This project generated 6,500 cubic meters of contaminated soils (low level radioactive waste) in 1991.

\section{Badienuclide Cencentration}

The radionuclide content of waste generated and disposed at the SRS will be contained in DCE/RW-006, Rev. 7, "Integrated Data Base for 1991: U. S. Spent Fuel and Radioactive Waste Inventories, Projecticns, and Characteristics" to be prepared by Oak Ridge National Laboratory under contract No. DE-AC05-84 OR21400 for the U. S. Department of Energy.

\section{Environmental Restoration Waste}

Environmental restoration work in CY1991 produced approximately 290 cubic meters of low level waste. Most of this work was due to Tank $105 \mathrm{C}$ closure. The Environmental Restoration Department has developed a facility specific waste minimization plan. Preliminary analysis and investigation indicates that incorporating waste minimization into environmental restoration projects will be limited by regulatory and legal restrictions. Efforts will continue to increase waste minimization on these projects within the limits allowed by law. 


\section{APPENDIX A}

\section{WASTE REDUCTION HIERARCHY}


Appendix A

Page 1 of 1

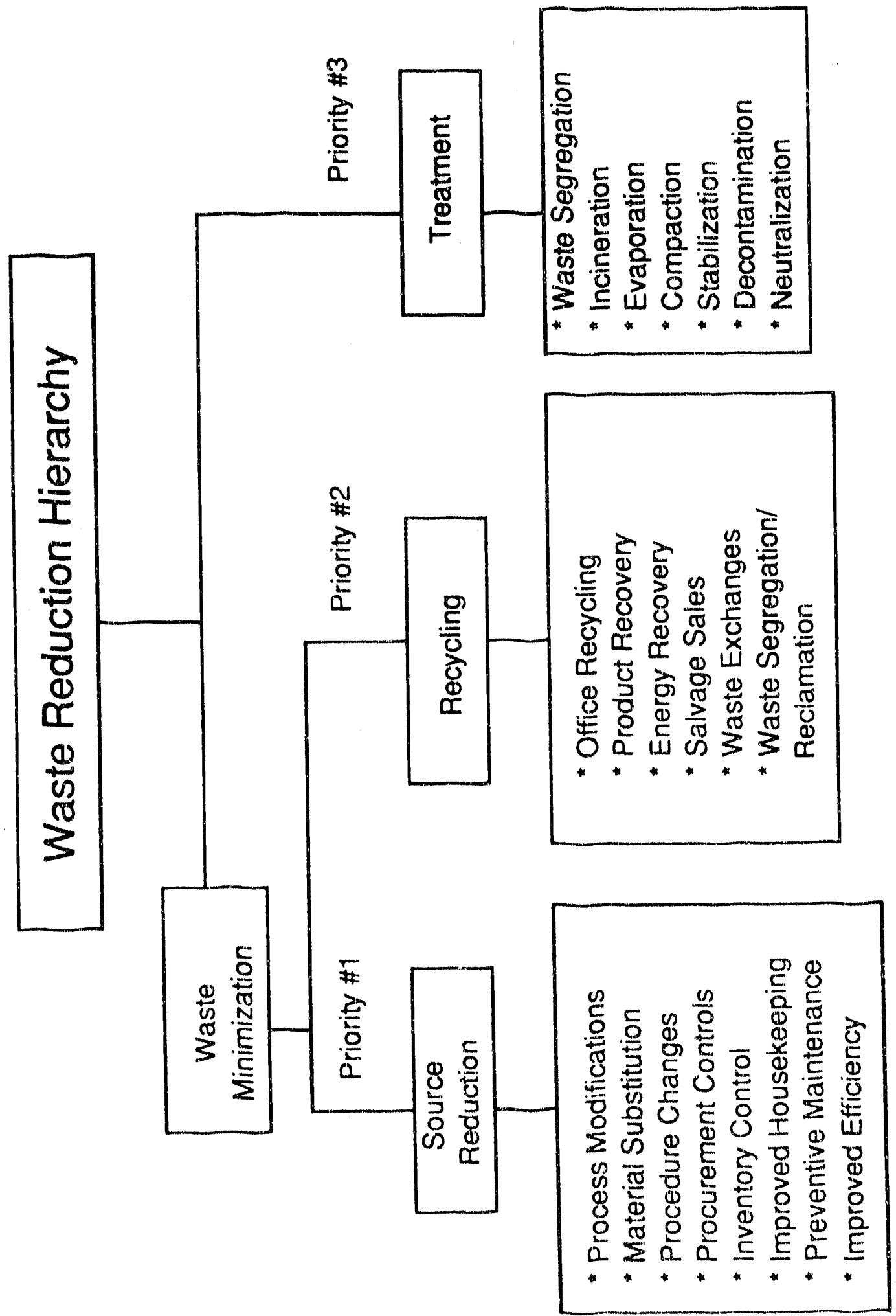




\section{APPENDIX B}

SRS WASTE REDUCTION ORGANIZATION 
Appendix B

Page 1 of 2

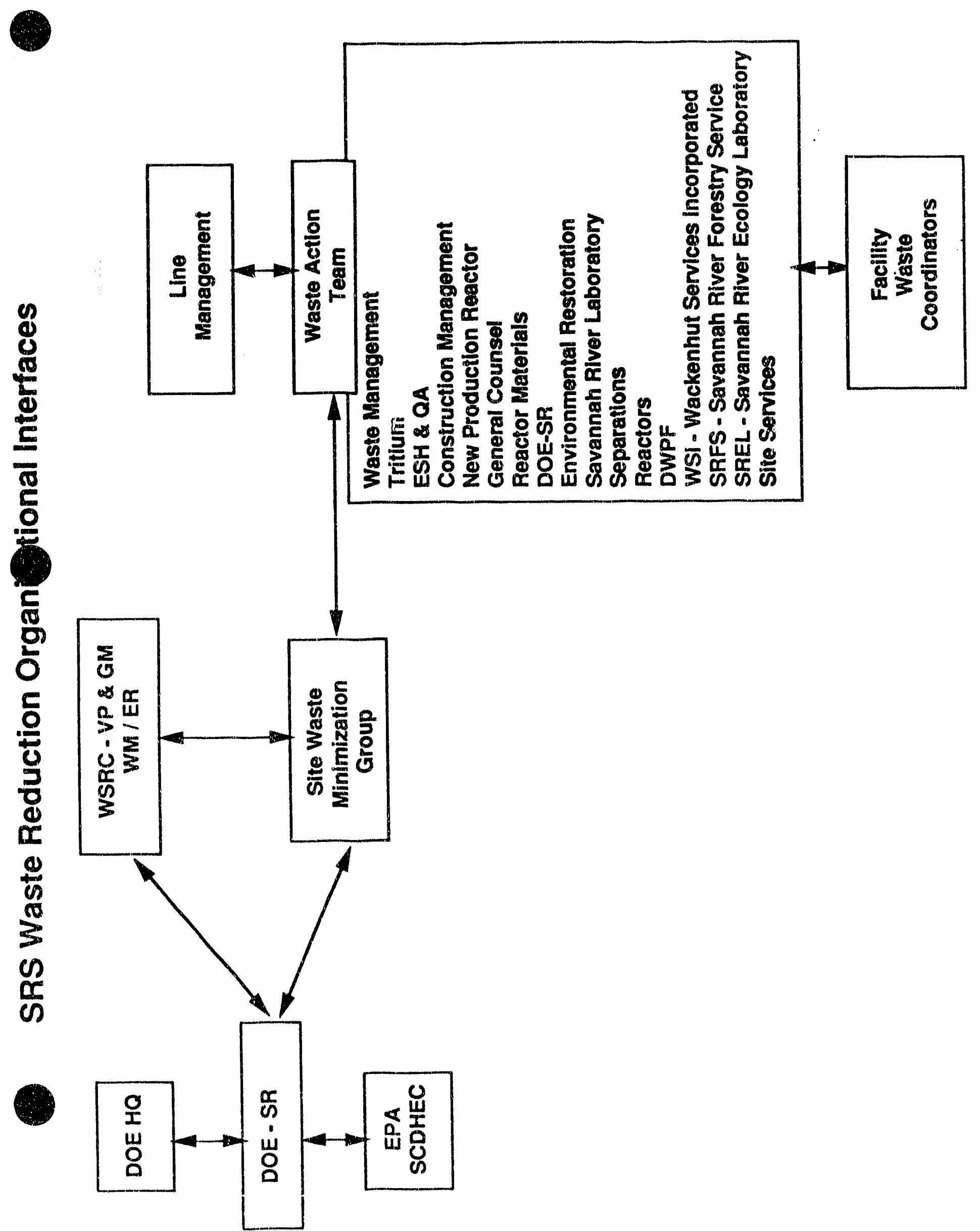


Appendix B

Page 2 of 2

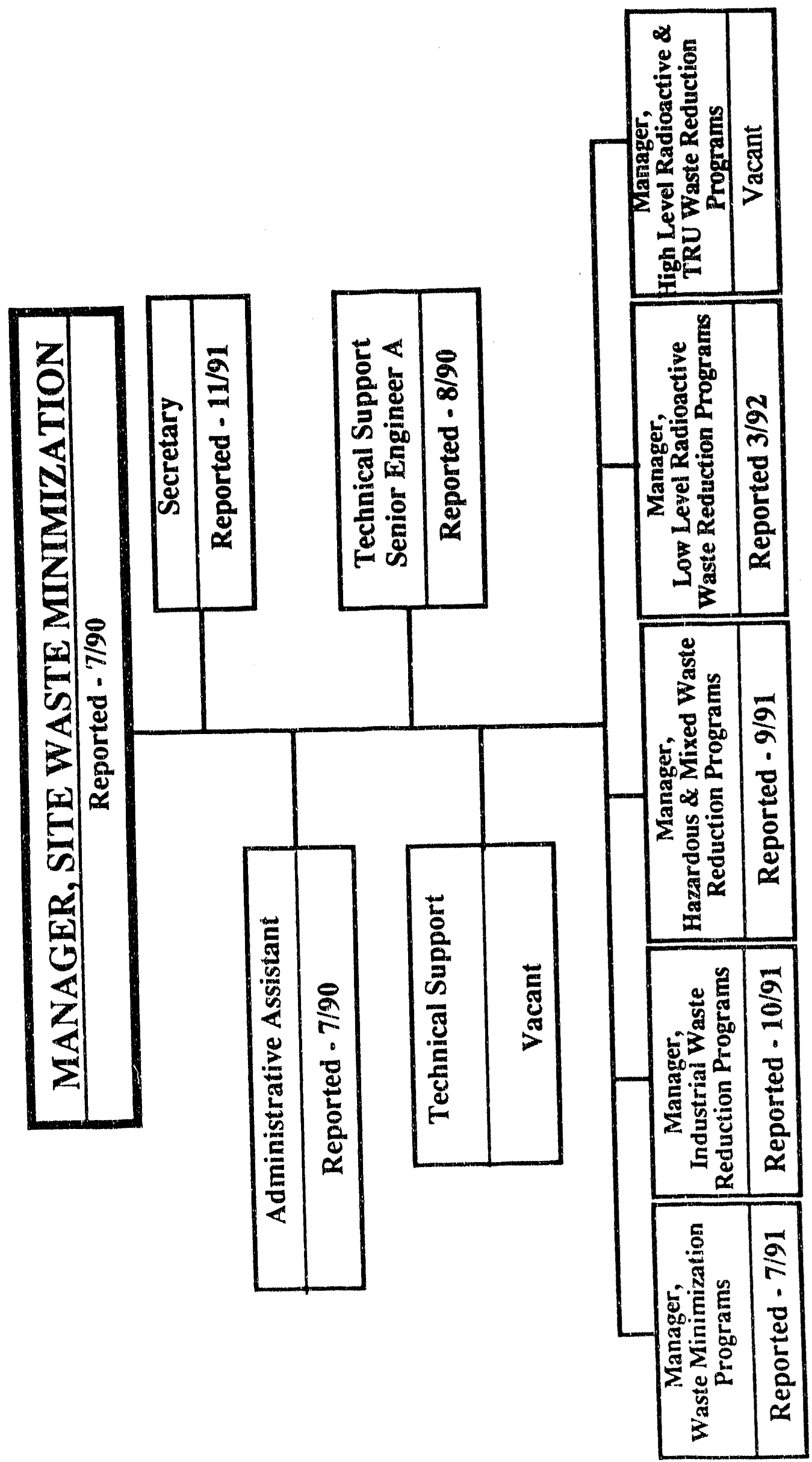




\section{APPENDIX C}

\section{PROGRAMMATIC MILESTONES}




\section{Programmatic Milestones}

\section{Activity}

Publish status of major waste minimization program milestones in the Site Waste Minimization Monthly Report

Issue WSRC Waste Minimization Policy

Issue revised Site Waste

Minimization Plan

Expand aluminum can recycle program sitewide

Issue Facility Specific Waste Minimization Plans for each facility that generates hazardous, radioactive, or mixed waste

Establish waste generation baselines for major waste generators
Completion Responsibility/Comments Goal Date

On-going

$3 / 91$

$3 / 91$

$3 / 91$

$3 / 91-9 / 91$

$3 / 91-9 / 91$ waste generation in each facility

$6 / 91$

(to be revised)
All waste generating departments - Milestone to be revised; status of basis for issued by letter, R.A. Lee to J.A. Wright $9 / 30 / 91$

Site Waste Minimization Monthly Report issued each month

Site Waste Minimization -

Complete; WSRC-1-01, MP4.1 authorized $3 / 28 / 91$

Site Waste Minimization Revision 3 issued 3/91

Recycle Task Team Complete $3 / 91$

All waste generating departments -

31 plans issued by $9 / 91$

26 revised by $1 / 92$

All waste generating departments - Basic program is defined in Rev. 4 of Site Waste Minimization Plan. Details for each area are being included in revisions to Facility Specific Waste Minimization Plans.
Formalize internal program for evaluating Waste Minimization Program performance as part of facility specific plans in each area generating radioactive and/or hazardous waste 


\section{Activity}

Develop guidance and strategy for process waste assessments

Establish pilot program for recycling of paper/cardboard

Waste Acceptance Criteria and Waste Certification Program for all solid waste handled by Waste Management to be issued for approval

Issue detailed schedule for generator implementation of Waste Certification Program

Modify site-level procedures to include the handling and minimization of waste as a part of each job plan

Establish waste generation as a 11/91 Performance Indicator to be reviewed each month by site management

Issue revised Site Waste

Minimization \& Pollution

Prevention Plan

Compile and issue schedule for $1 / 92$ process waste assessments from schedules developed by waste generators.

$6 / 91$

$6 / 91$

$7 / 91$

$9 / 91$
Completion Responsibility/Comments Goal Date

(to be revised)

2 months following program approval

Site Waste Minimization Modification to site level procedures complete; Division/Department procedures to be revised by $4 / 92$

All waste generating departments - Complete

Site Waste Minimization Group complete: Revision 4 issued $1 / 92$

Waste generators/SWMGcomplete; issued $2 / 92$ 


\section{Activity}

Issue life cycle cost of waste generated in 1992

Issue detailed schedule for generator implementation of Waste Certification Program.

Issue plan \& path forward that assures implementation of a procurement contro! and excess material program by $9 / 92$

Implement comprehensive audit program as outlined in this plan for assessing waste minimization performance.

Develop training programs for: Waste Action Team Members Waste Coordinators Design Engineers Process Waste Assessments

Modify department-level procedures to include the handling and minimization of waste as a part of each job plan.

Establish pilot program for recycling of cardboard

Implement aluminum can recycle program site wide.

WITS implemented to support Solid Waste Disposal Facility Exparsison.
Completion Responsibility/Comments Goal Date

$3 / 92$

Long Range Planning/SWMG

2 months

after

approval

$3 / 92$

Site Waste Minimization Group
$4 / 92$
$4 / 92$
$5 / 92$
$6 / 92$
$6 / 92$

$4 / 92$

$6 / 92$

$6 / 92$

9/92(prior to E-Area vault start-up)

Site Waste Minimization Group

\begin{abstract}
All waste generating departments, ESH\&QA, and DOE-SR
\end{abstract}

Waste Management Technology

All waste generating departments

Site Waste Minimization Group

Recycie Task Team

Implement a procurement control $9 / 92$ and excess materials program

To be defined by plan issued in $3 / 92$ 
Activity

Evaluate/Revise SWMP

Forecast annual waste volume generation for each operating area.

Establish annual waste reduction Annually by goals

Issue revised FSWMPS

Establish pilot program for recycle of paper

\section{Completion Responsibility/Comments} Goal Date

Annually by Site Waste Minimization Group Oct. 31

Annually by All waste generating

Oct. 31 departments working with Waste Management Technology Dept.

All waste generating departments working with Waste Management Technology Dept.

Annually by All waste generating

Dec. 31 departments

$12 / 92$ 
APPENDIX D

AWARD FEE CRITERIA 


\section{Award Fee Criteria}

\section{Period 4,5,\& 6}

\section{Peried 4 Award Fee $(10 / 1 / 90-3 / 31 / 91$}

\section{Performance Objective:}

C.3 Establish and maintain a comprehensive and effective waste minimization program

\section{Performance criterion:}

C.3.1 Effectiveness in implementation of the comprehensive waste minimization plan

\section{Performance Indicators:}

C.3.1.1 Waste Minimization activities are focused, directed and criteria established and the management systems are in place to control volume reductions.

C.3.1.2 WSRC will develop a baseline for future waste minimization activities and establish and achieve goals for waste volume reduction.

C.3.1.3 All generators have active programs for waste minimization and senior management is providing appropriate direction and leadership.

C.3.1.4 Incentives and penalties are in place for performance by generators on waste minimization at the facility level.

C.3.1.5 An active audit program is in place to enforce waste minimization practices.

C.3.1.6 Develop and impleinent a plan to make waste minimization a part of each job plan that involves waste generation similar to safety and health protection.

C.3.1.7 Meet objectives and milestones contained in the Waste Minimization Plan. ". 


\section{Peried 5 Award Fee (4/1/91-9/30/91)}

\section{Performance Objective}

C.3 Continue and enhance implementation per DOE program requirements a comprehensive waste minimization program.

\section{Performance Criteria}

C.3.1 Continually improve implementation of the latest revision of the comprehensive waste minimization plan.

\section{Performance Assessment Facior}

C.3.1.1 Meet objectives and milestones contained in the Waste Minimization Plan.

C.3.1.2 Increase use of compactors as a waste minimization tool based on defined studies, analyses, and requested funding.

C.3.1.3 Develop and implement facility specific waste minimization plans per agreed upon schedules.

\section{Peried 6 Aware Fee (10/1/91-3/31/92)}

\section{Performance Objectives}

C.4 Achieve and demonstrate full compliance with environmental, safety, health, quality assurance, and waste minimization requirements in Environmental Restoration and Waste Management (ERWM) facilities, consistent with agreed upon schedules and approved funding.

\section{Performance Criteria}

C.4.1 Demonstrate, through implementation and documentation, compliance with DOE environmental, safety, health, and quality assurance requirements in ERWM facilities.

\section{Performance Assessment Facters}

C.4.1.7 Meet objectives and milestones contained in the Waste Minimization Plan. 


\section{APPENDIX E}

1992 WASTE ASSESSMENT SCHEDULE 
Appendix $E$

Page 1 of 1

\section{WASTE MINIMIZATION ASSESSMENTS}

BY SITE WASTE MINIMIZATION GROUP

$\begin{array}{ll}\text { MONTH } & \text { FACILITY/ORGANIZATION } \\ \text { January } & \text { TNX(semi-works facility) } \\ \text { February } & 299-\mathrm{H} \\ \text { March } & \text { Tritium Facilities } \\ \text { April } & \text { F-Tank Farm } \\ \text { May } & \text { Construction } \\ \text { June } & \text { DWPF/Z Area } \\ \text { July } & \text { H Tank Farm } \\ \text { August } & \text { Site Services Department } \\ \text { September } & \text { K-Area } \\ \text { October } & \text { Reactor Materials Department } \\ \text { November } & \text { HB-Line } \\ \text { December } & \text { F-Canyon }\end{array}$




\section{APPENDIX F}

WASTE GENERATION DATA 
Appendix F

Page 1 of 7

孷

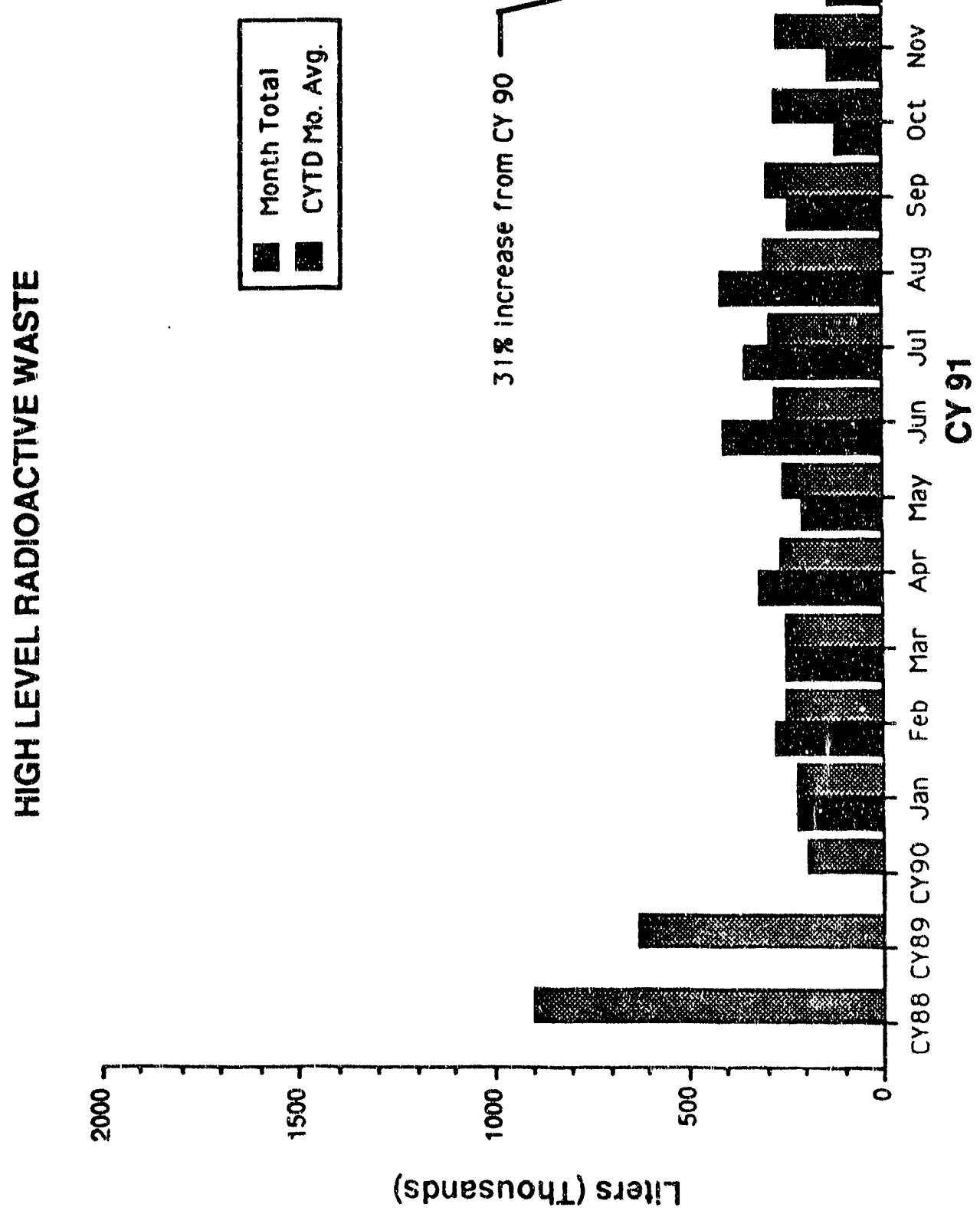



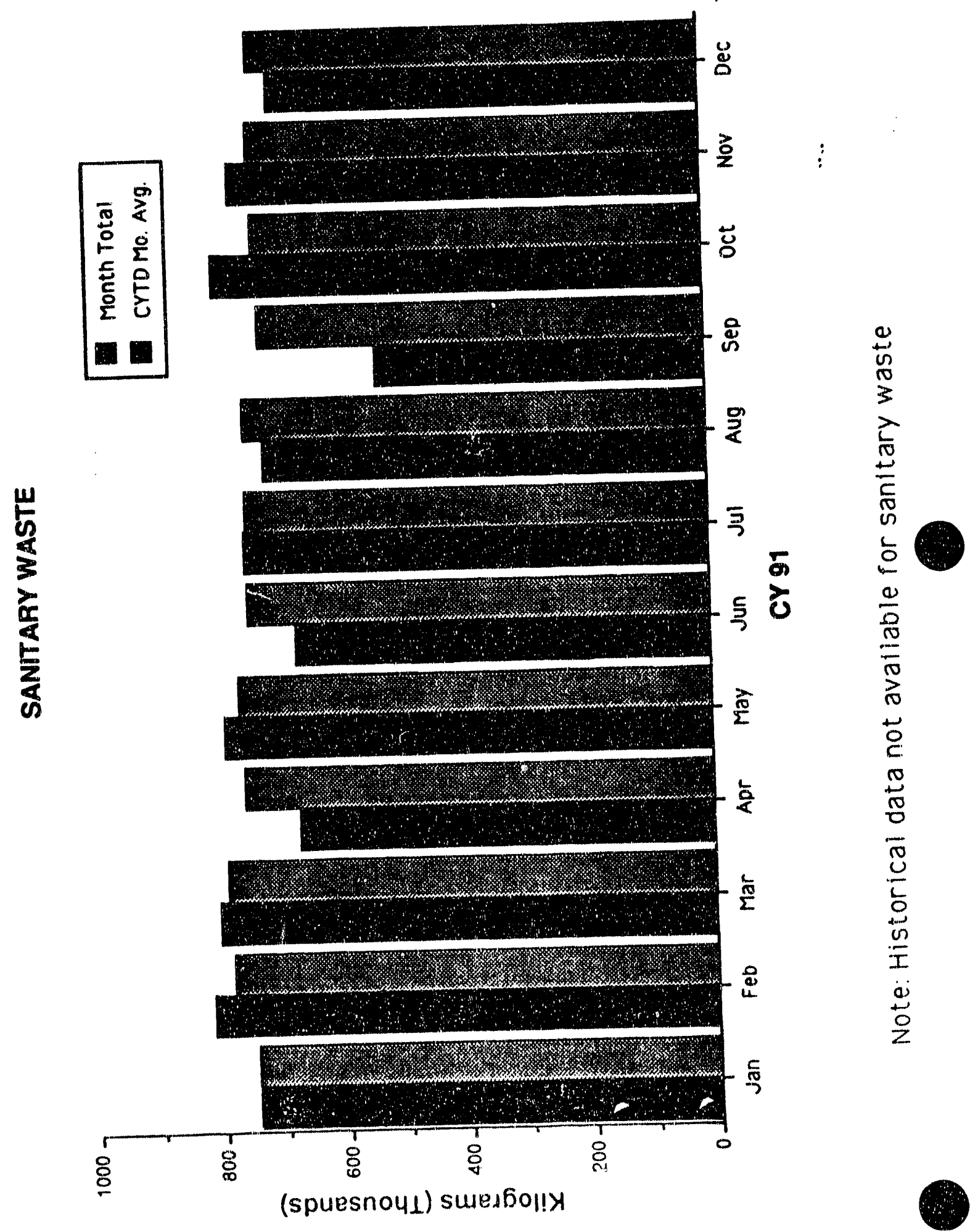
Appendix $F$

Page 3 of 7

$\frac{1}{3}$

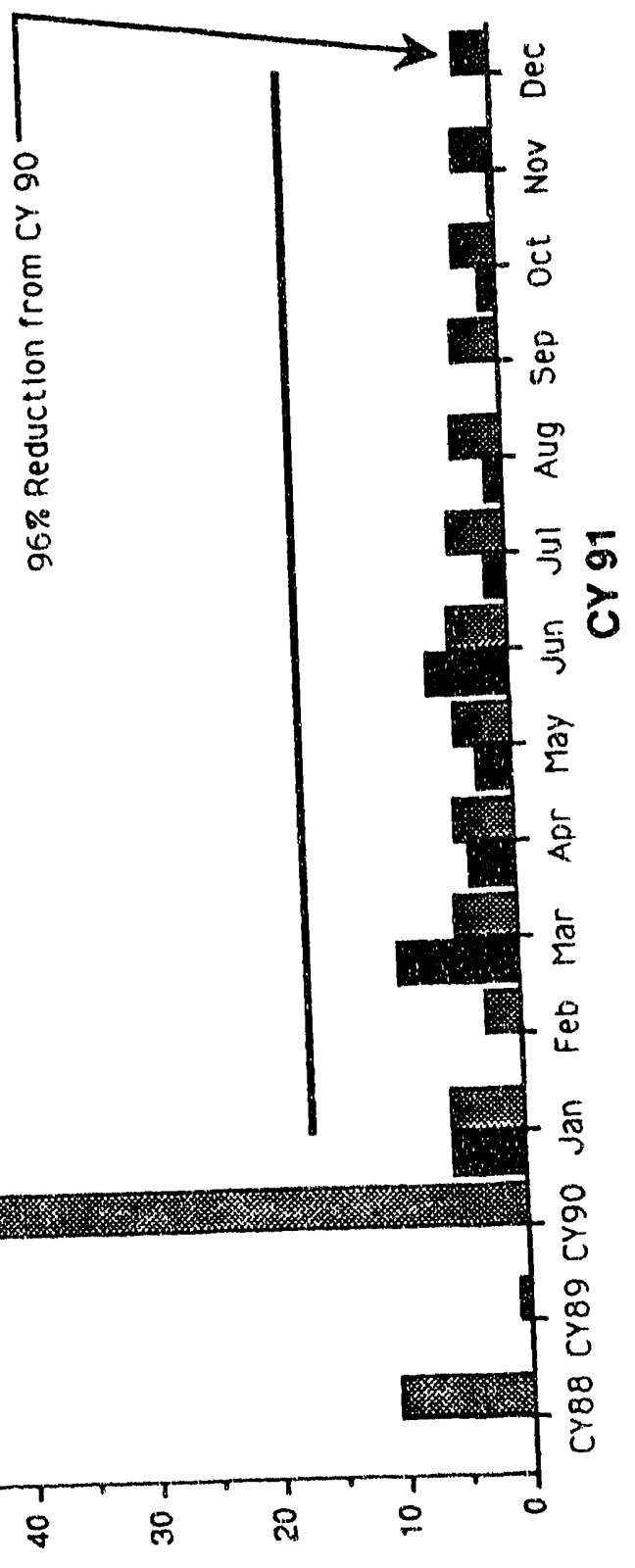

ssəıəW ग!qno 
Appendix $F$

Page 4 of 7

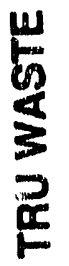

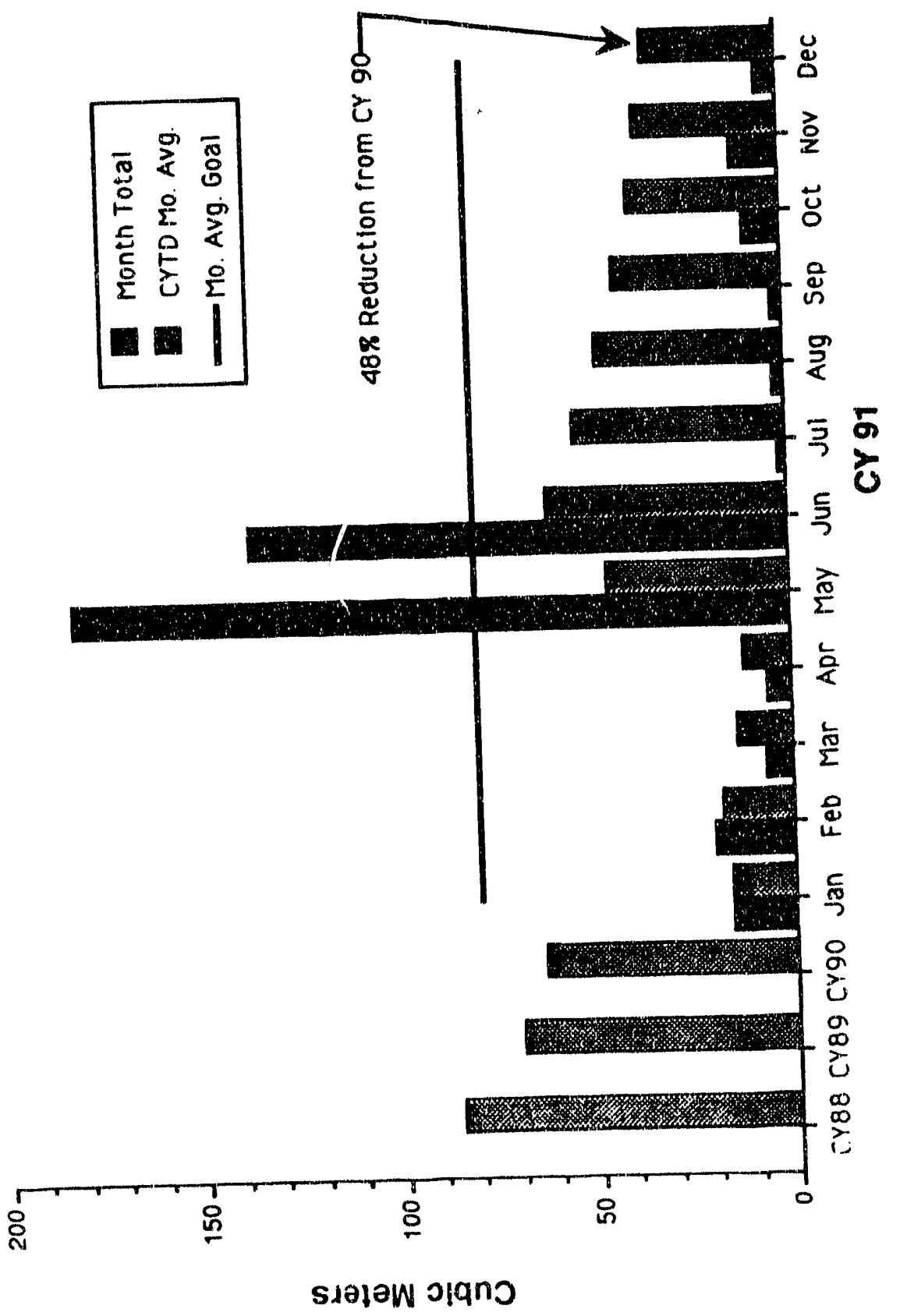


Appendix $F$

Page 5 of 7

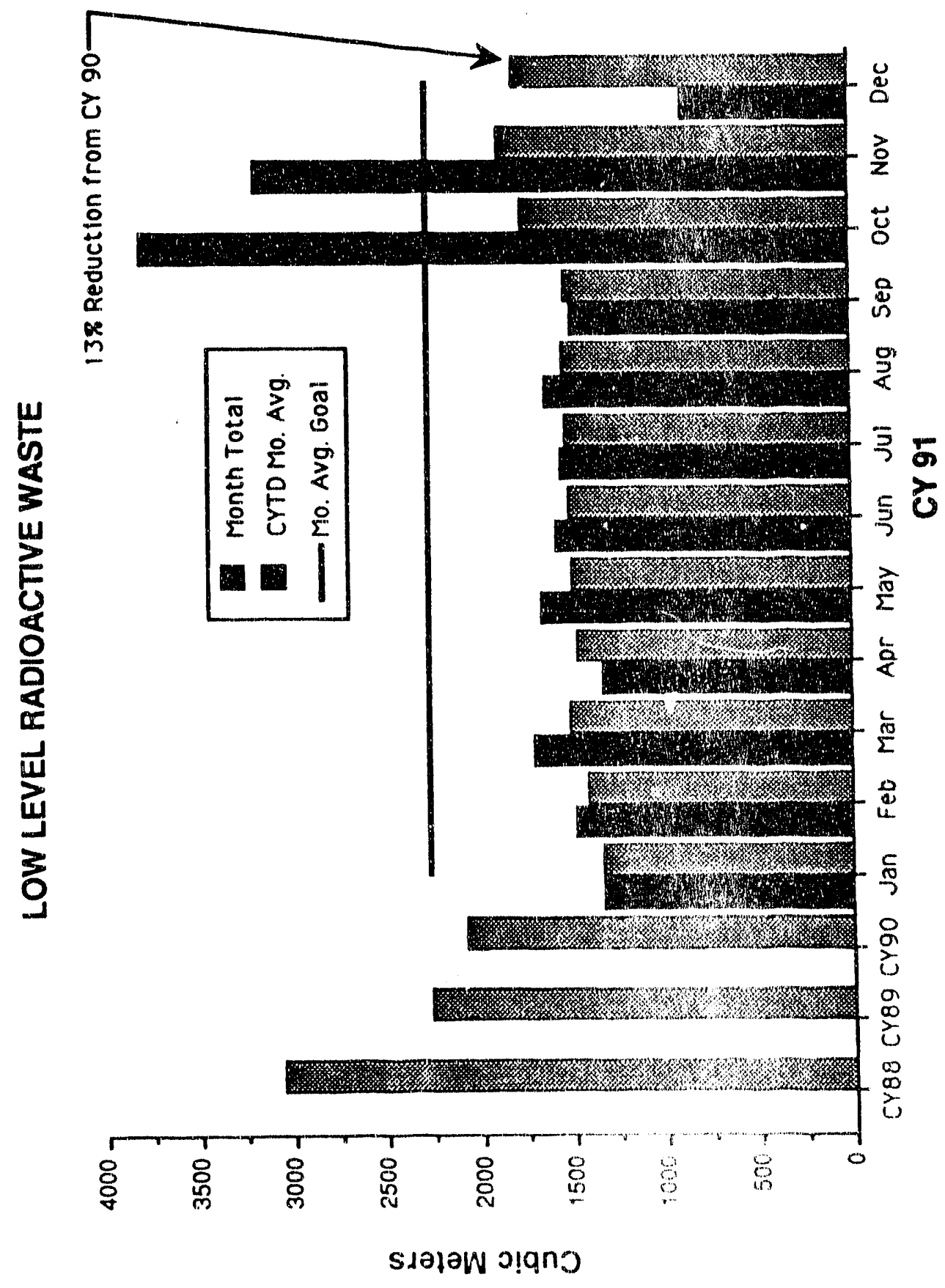


Appendix F

Page 6 of 7

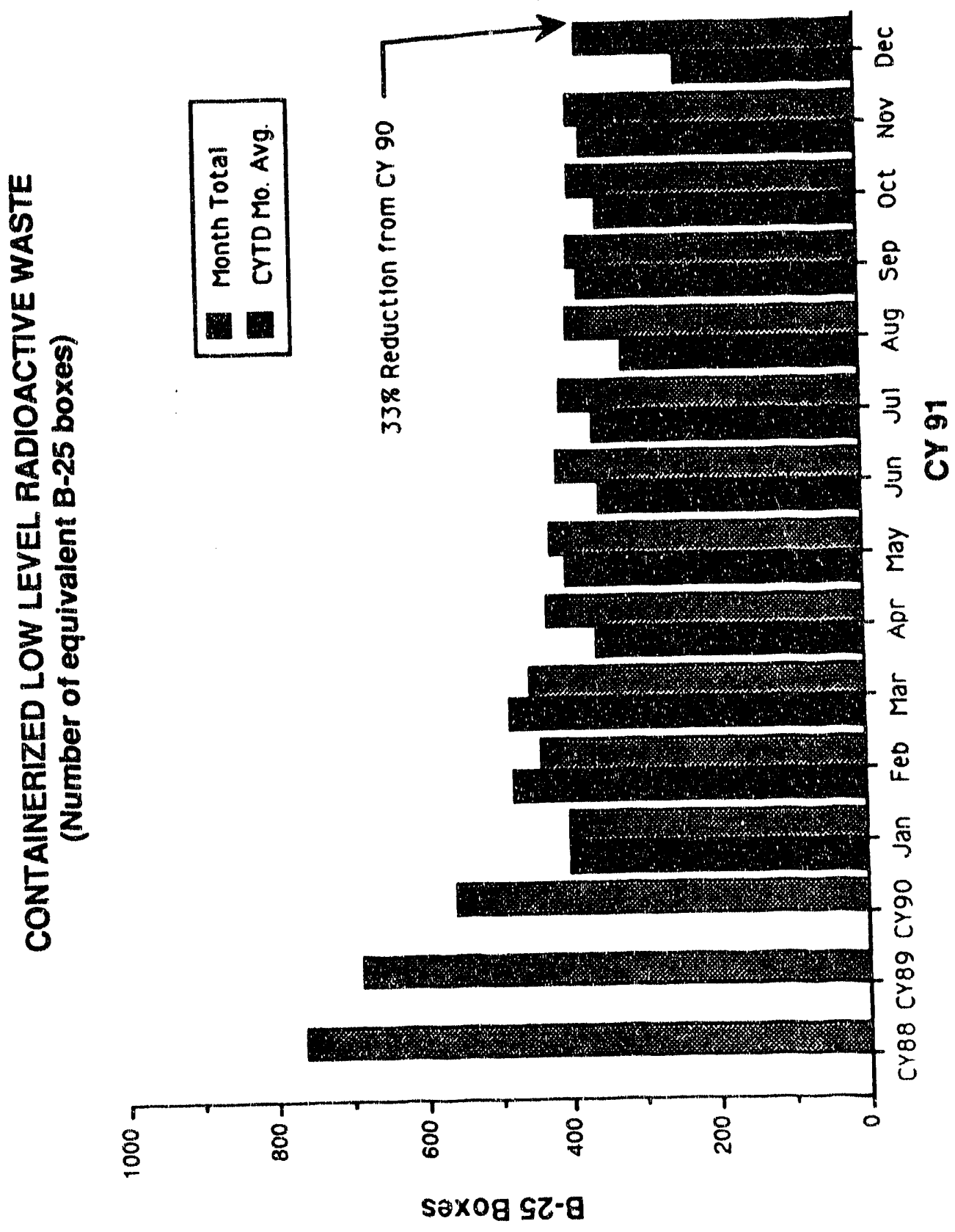


Appendix $\mathrm{F}$

Page 7 of 7

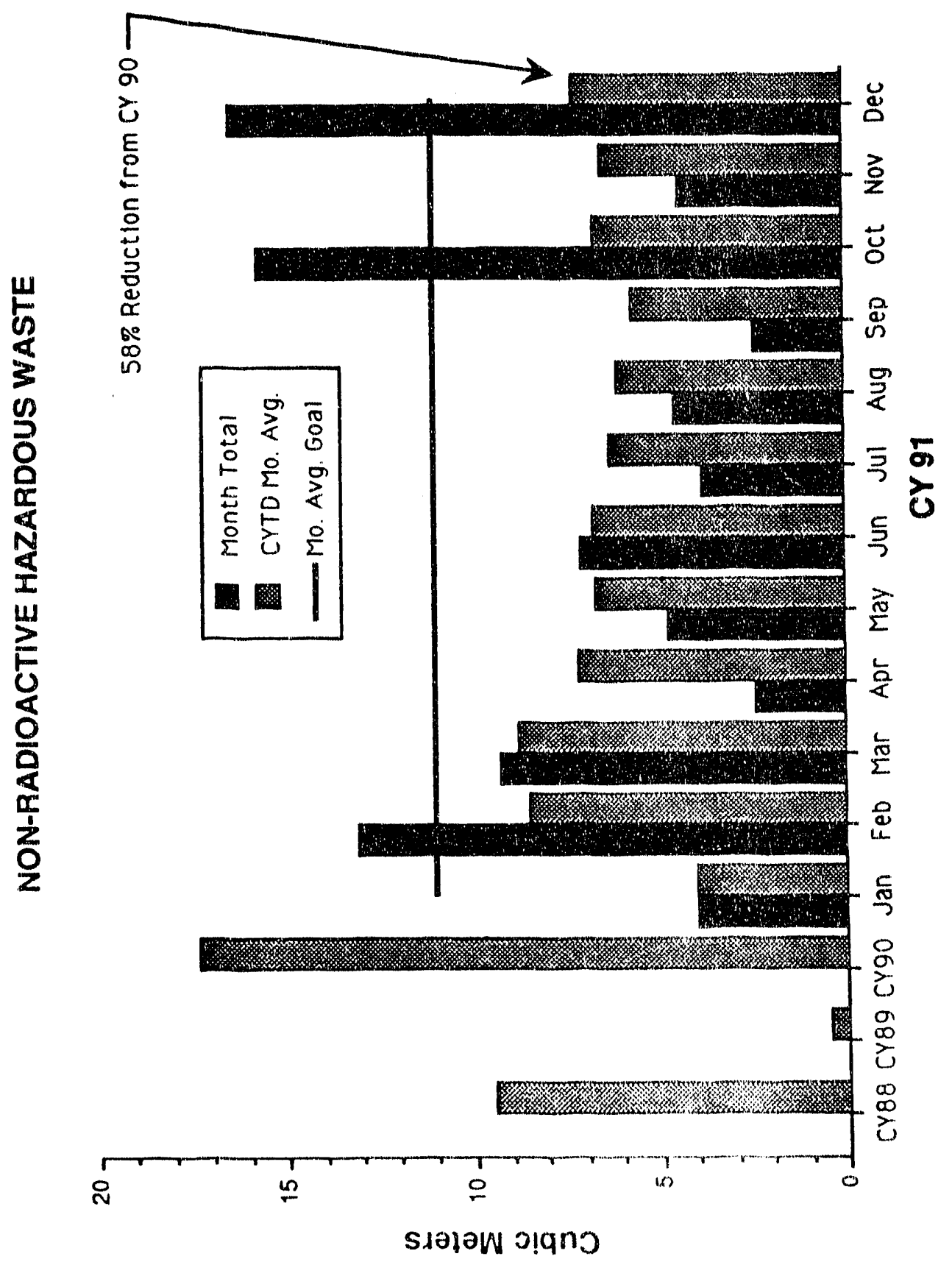




\section{APPENDIX G}

SRS SOLID WASTE FORECAST 


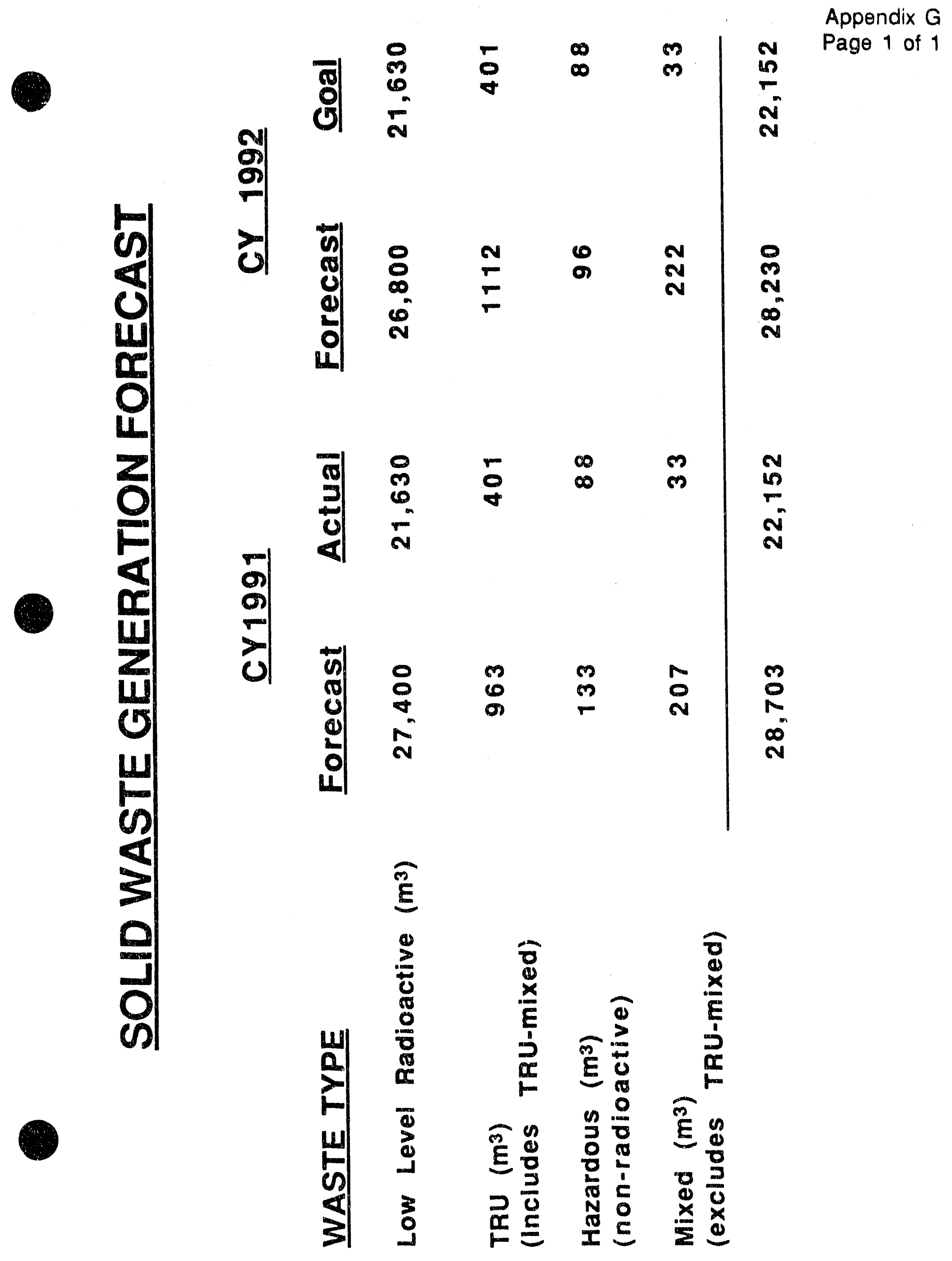




\section{APPENDIX H}

\section{COST TABLES}


Appendix $\mathrm{H}$

Page 1 of 3

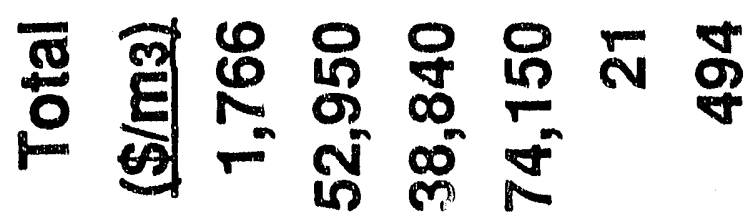

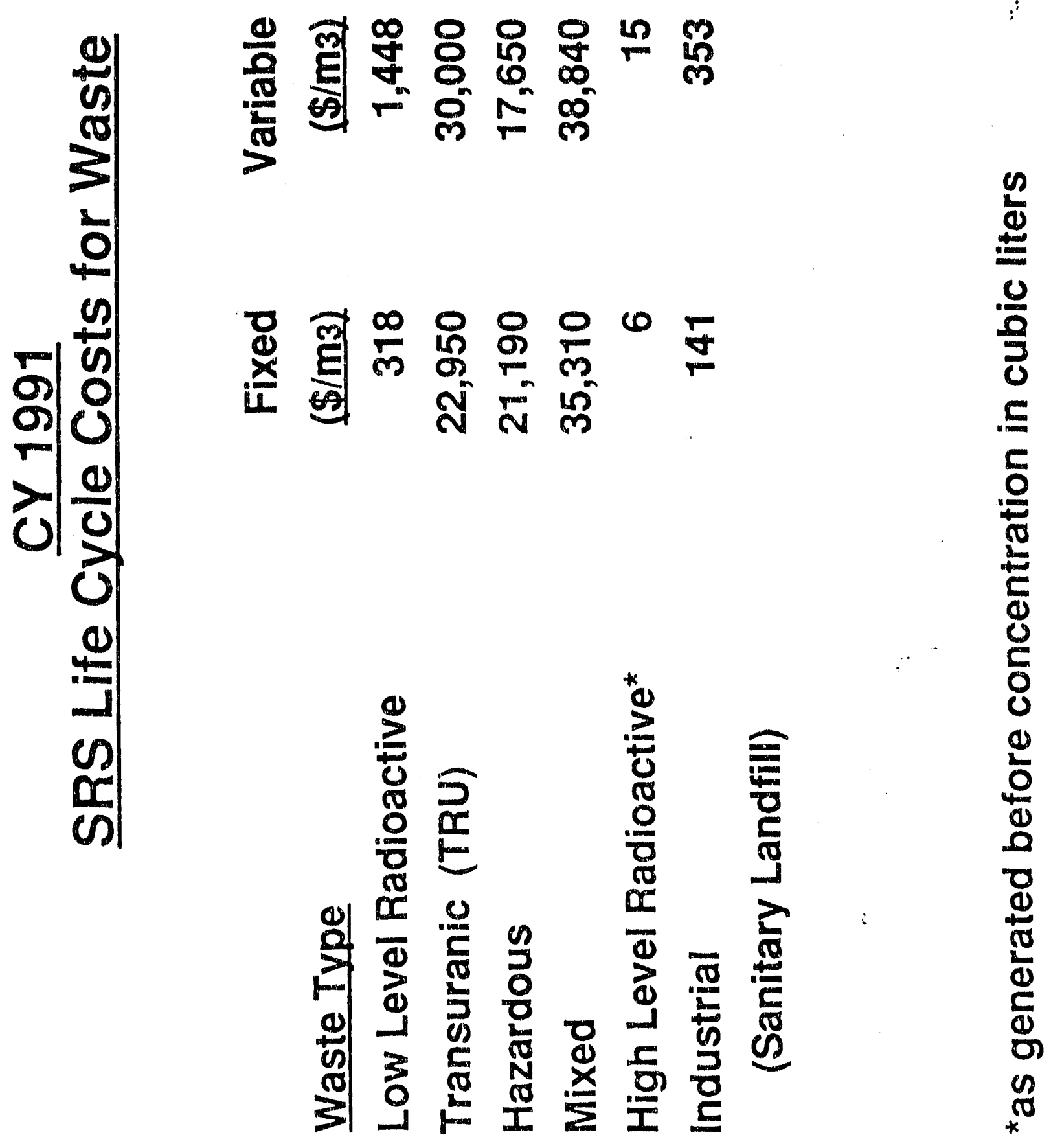


Appendix $\mathrm{H}$

Page 2 of 3

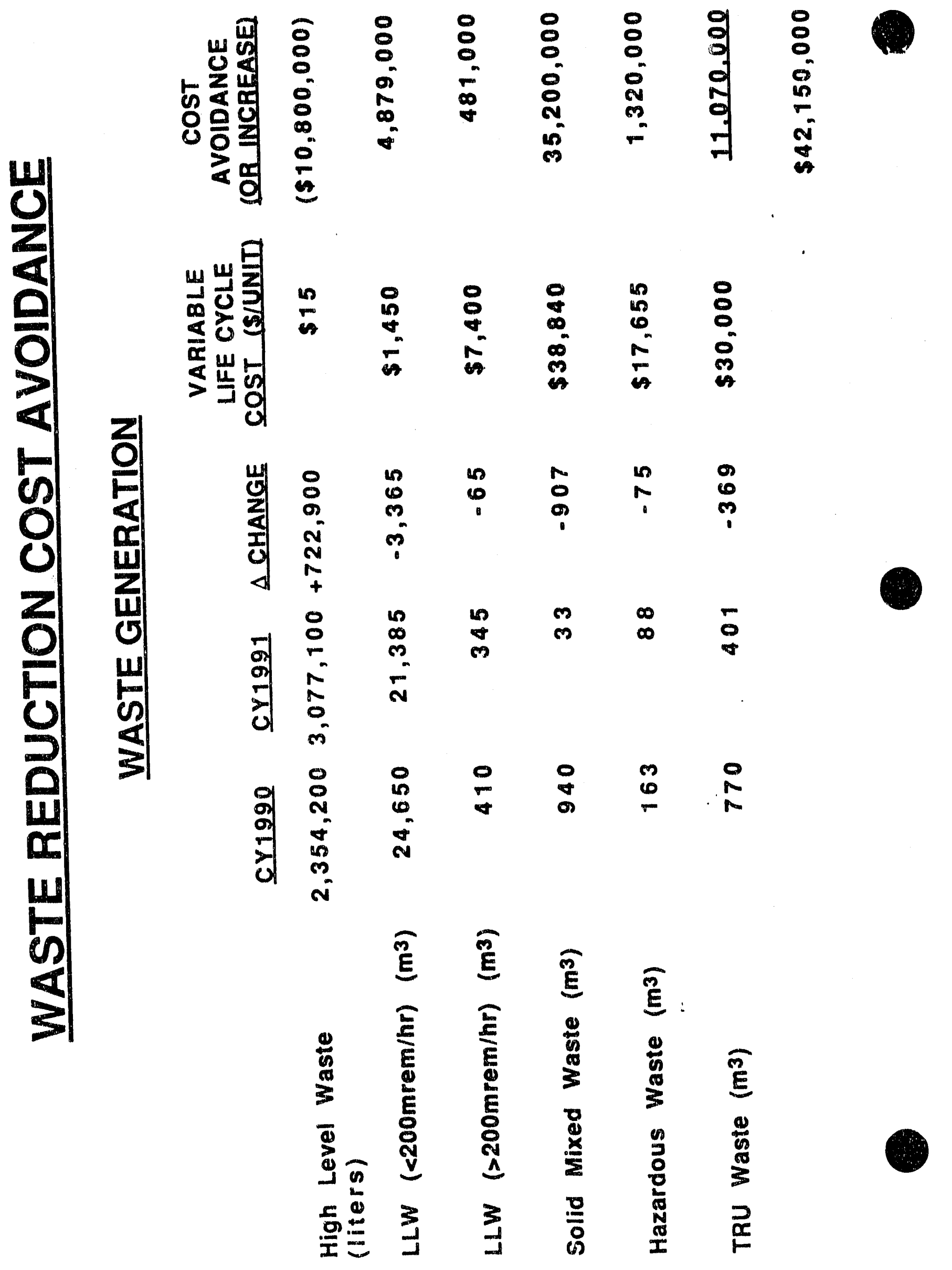




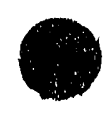

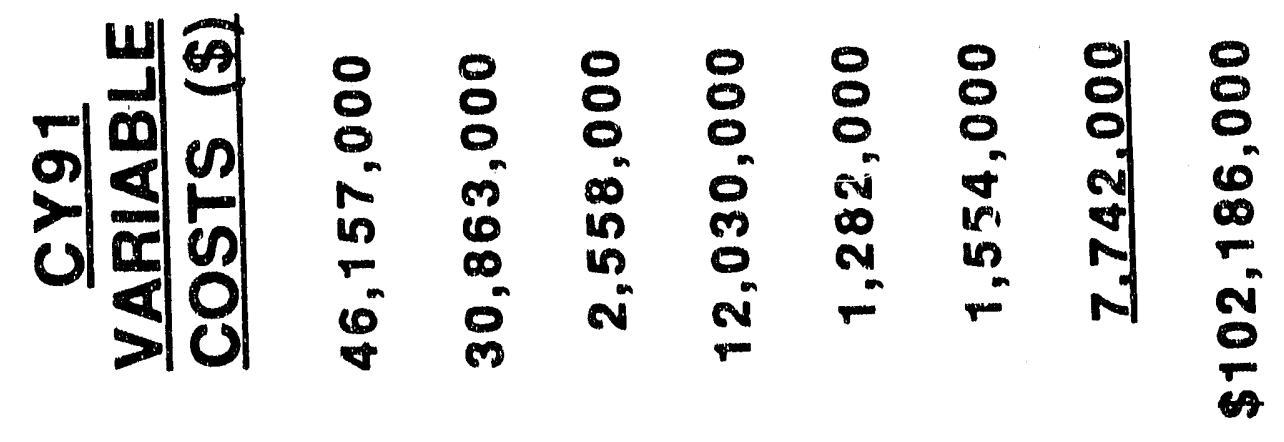

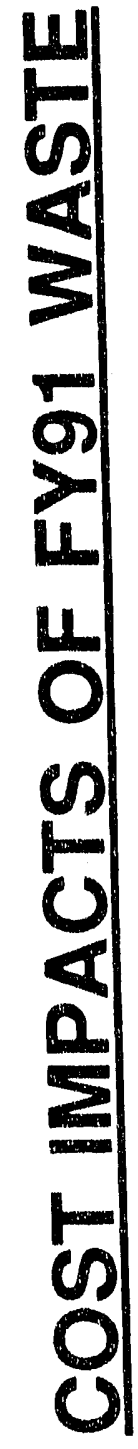

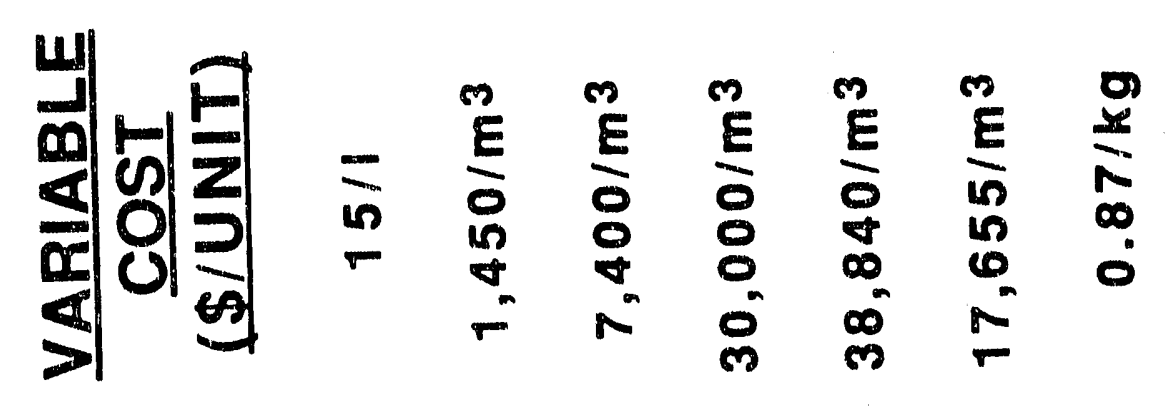

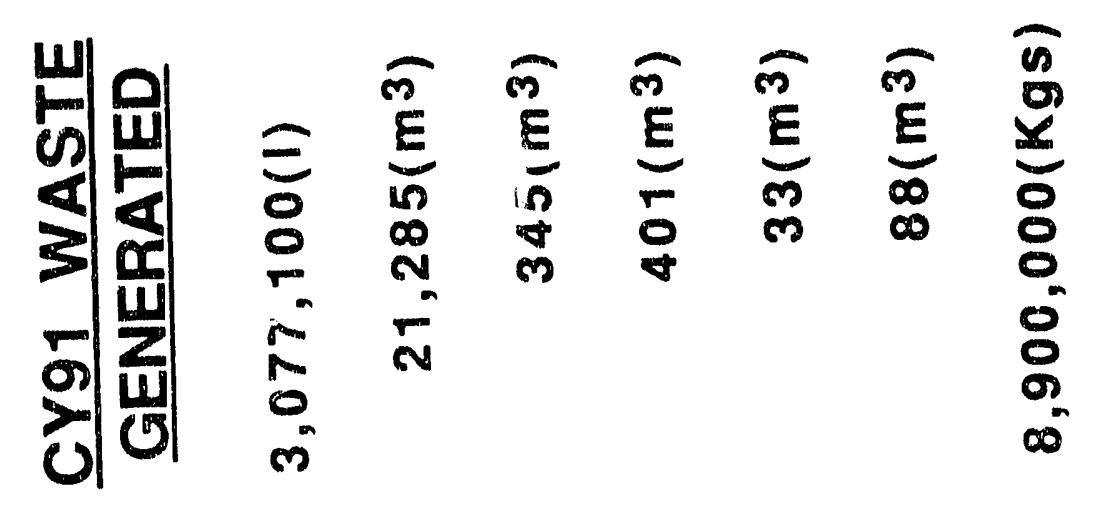

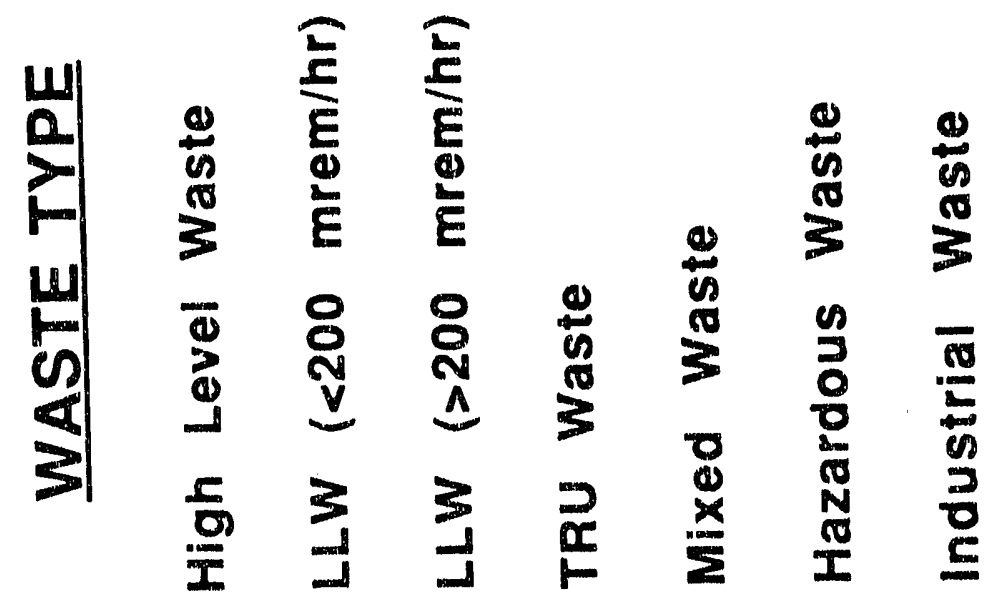




\section{APPENDIX I}

1991 SRS RECYCLE SUMMARY 


\section{CY1921_RECYCLING SUMMARY}

$\begin{array}{llc}\text { Material } & \begin{array}{l}\text { Responsible } \\ \text { Qrganization }\end{array} & \text { CY J29 } \\ \text { Anti-freeze } & \text { Construction } & 14,000 \text { liters } \\ \text { Construction Chemicals } & \text { Construction } & 7,260 \mathrm{~kg} \\ \text { Construction Compounds } & \text { Construction } & 12,000 \mathrm{~kg} \\ \text { Latex Paint Rinse Water } & \text { Construction } & 22,000 \mathrm{liters} \\ \text { Lead } & \text { Construction } & 9,900 \mathrm{~kg} \\ \text { Paint Solvent } & \text { Construction } & 760 \mathrm{liters} \\ \text { Pressure Treated Lumber } & \text { Construction } & 297,560 \mathrm{~kg} \\ \text { Used Oil } & \text { Power } & 212,740 \mathrm{liters} \\ \text { Aluminum Cans } & \text { Salvage } & 6,350 \mathrm{~kg} \\ \text { Batteries } & \text { Salvage } & 2542 \\ \text { Copper } & \text { Salvage } & 51,000 \mathrm{~kg} \\ \text { Drums (30 and 55 gal) } & \text { Salvage } & 4,988 \\ \text { Scrap Aluminum } & \text { Salvage } & 60,870 \mathrm{~kg} \\ \text { Scrap Metal } & \text { Salvage } & 1,968,600 \mathrm{~kg} \\ \text { Stainless Steel } & \text { Salvage } & 187,800 \mathrm{~kg} \\ \text { Tires } & \text { Salvage } & 5,066 \\ \text { Toner Cartridges } & \text { Salvage } & 2,852 \\ \text { Weld Rod Stubs } & \text { Salvage } & 14,000 \mathrm{~kg} \\ & & \end{array}$




\section{APPENDIX J}

SRS PROCESS WASTE ASSESSMENT SCHEDULE 


\section{SRS Process Waste Assessment Schedule}

\section{Encillty}

244-H, 245-H

$244-H, 245-H$

244-H, 245-H

Administrative

Servicos

\section{Central Laboratory}

Facilitios

Construction

Consiruction

Construction

Construction

CSWE

CSWE

CSWE

DC \&S

Environmental

Restoration

ETF

F-Canyon \& OF-F

F-Canyon \& OF-F

F. Canyon \& OF-F

F.Canyon \& OF-F

F-Canyon \& OF-F

Facility \& Services

FB-Line/NSR/PSF

Financial Management \& Information Systems

\section{H-Canyon}

H-Canyon

H-Canyon

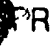

Power start completion

Dete Date

1/1/92

1/1/95

$9 / 1 / 96$

$1 / 31 / 92$

9/30/92

12/31/91

4/30/92

$5 / 31 / 92$

6/30/92

$10 / 31 / 91$

$8 / 30 / 92$

$1 / 31 / 93$

$5 / 31 / 92$

PWA for 480-2D Waste Paint Paint Solvent

PWA for 716-A,717-A,622-G,717-D Waste Solvent Rags

PWA for 710-G Waste Paint/Paint Solvent

PWA for DC\&S not required.

PWA for Environmental Restoration activities as part of closure.

PWA for ETF not scheduled

1/31/92

7/1/92

$1 / 1 / 93$

$7 / 1 / 93$

$1 / 1 / 94$

1/1/92

$7 / 1 / 92$

$1 / 1 / 93$

\section{Erocens}

PWA for High Lovel Liquid Waste

PWA for Low Lovel Wasto

PWA for Intormodiato Lovol Waste

PWA for division not required

PWA for Central Laboratory Facility

PWA for Paint Solvents

PWA for Lead Melter HEPA filters

PWA for Spent Silver Fixative

PWA for Solvent Rags \& Wipes

PWA for LLW in F-Canyon

$6 / 30 / 92$

PWA for LLW in OF-F

6130103

PWA for High Level Liquid Wasto in F-Canyon

12/31/93 PWA tor HLLW in OF-F

6/30/94 PWA for Intermediate Level Waste in F-Canyon

12/31/94 PWA tor 723-F laundry

12/31/92 PWA for LLW

PWA for FM\&IS not required.

6/30/92 PWA for Solid Low Level Waste, 221 +H

12/30/92 iWA for Intermediate Low Level Waste, 221-H

12/30/93 PWA for Liquid Waste, 221-H

PWA for New Production Fieactor conducted as part of on-going

PWA for Power Operation not required. 


\section{SRS Process Waste Assessment Schedule}

\begin{tabular}{|c|c|c|c|}
\hline Enallix & $\frac{\text { Sthrt }}{\text { Dete }}$ & $\begin{array}{c}\text { Complotion } \\
\text { Dete }\end{array}$ & Procens \\
\hline Reactor Aroas & $1 / 1 / 91$ & 1/31/93 & PWA for L-Roactor Low Lovel Waste Stream \\
\hline Reactor Areas & $1 / 1 / 93$ & 1/31/94 & PWA for K-Reactor Low Lovel Wasto Stroam \\
\hline Reactor Areas & $1 / 1 / 83$ & $1 / 31 / 94$ & PWA for RRD mixed westo \\
\hline Reactor Areas & $1 / 1 / 84$ & $1 / 1 / 95$ & PWA for rernainder of Low Level Waste streams $(>\$ 500,000)$ in \\
\hline Reactor Areas & $1 / 1 / 94$ & $1 / 1 / 95$ & PWA for remainder of mixed waste streams $(>\$ 500,000)$ in Reactor: \\
\hline Reactor Areas & $1 / 1 / 94$ & $1 / 1 / 95$ & PWA for remainder of hazardous waste streams $(>\$ 500,000)$ in \\
\hline Reactor Aroas & $1 / 1 / 94$ & $1 / 1 / 95$ & PWA for hazardous waste $(>500,000)$ in Reactor \\
\hline Reactor Areas & $1 / 1 / 95$ & $1 / 1 / 99$ & PWA for remainder of all waste streams $(<\$ 500,000)$ in Reactor \\
\hline Reactor Materials & $3 / 1 / 92$ & $9 / 30 / 92$ & PWA for 321-M Tube Cloaning Component Cleaning \\
\hline Reactor Materials & $6 / 1 / 92$ & $12 / 31 / 92$ & PWA for 320-M Tube Cleaning Room \\
\hline Reactor Materials & $6 / 1 / 92$ & $12 / 31 / 92$ & PWA for LETF (Liquid Effluent Treatment Facility) \\
\hline Reactor Materials & $9 / 30 / 92$ & $3 / 31 / 93$ & PWA for 313-M Supportservices \\
\hline Reactor Materials & $3 / 31 / 93$ & $9 / 30 / 93$ & PWA for 321-M Uranium Processing \\
\hline Roactor Materials & $3 / 31 / 93$ & $9 / 30 / 93$ & PWA for 320-M Makoup, Casting, Extrusion, Finishing \\
\hline Reactor Materials & $9 / 30 / 93$ & $3 / 31 / 94$ & PWA for 315-M Essential Materials Warehouse \\
\hline Reactor Materials & $1 / 31 / 94$ & $6 / 30 / 94$ & PWA for $322-M$ (four process to be completed-9/92, 6/93, 12/93, \\
\hline Reactor Matorials & $3 / 31 / 94$ & $9 / 30 / 94$ & PWA for $321-M$ Tube Assembly Area/toneycombs \\
\hline S-Area \& Z-Area & & & PWA for S and Z-Area not required (not operational) \\
\hline $\begin{array}{l}\text { Savannah River } \\
\text { Ecology Lab }\end{array}$ & & & PWA for SREL not required. \\
\hline $\begin{array}{l}\text { Savannah River } \\
\text { Laboratory }\end{array}$ & & & PWA for TRU waste will be scheduled in annual Waste Minimization \\
\hline $\begin{array}{l}\text { Savannah River } \\
\text { Laboratory }\end{array}$ & $1 / 31 / 92$ & $12 / 31 / 92$ & PWA for ULW \\
\hline SR Forest Service & & & PWA for SR Forostry Sorvice not requirod. \\
\hline Tritium & & $12 / 31 / 92$ & PWA for Low Level Waste \\
\hline Tritium & & $12 / 31 / 93$ & PWA for Intermediate Level Waste \\
\hline $\begin{array}{l}\text { Wackenhut Services } \\
\text { International }\end{array}$ & & & PWA for WSI-SRS not requirod. \\
\hline $\begin{array}{l}\text { Water Quality Lab. } \\
772 . D\end{array}$ & & & PWA for Water Quality Laboratory Facility is not required. \\
\hline
\end{tabular}



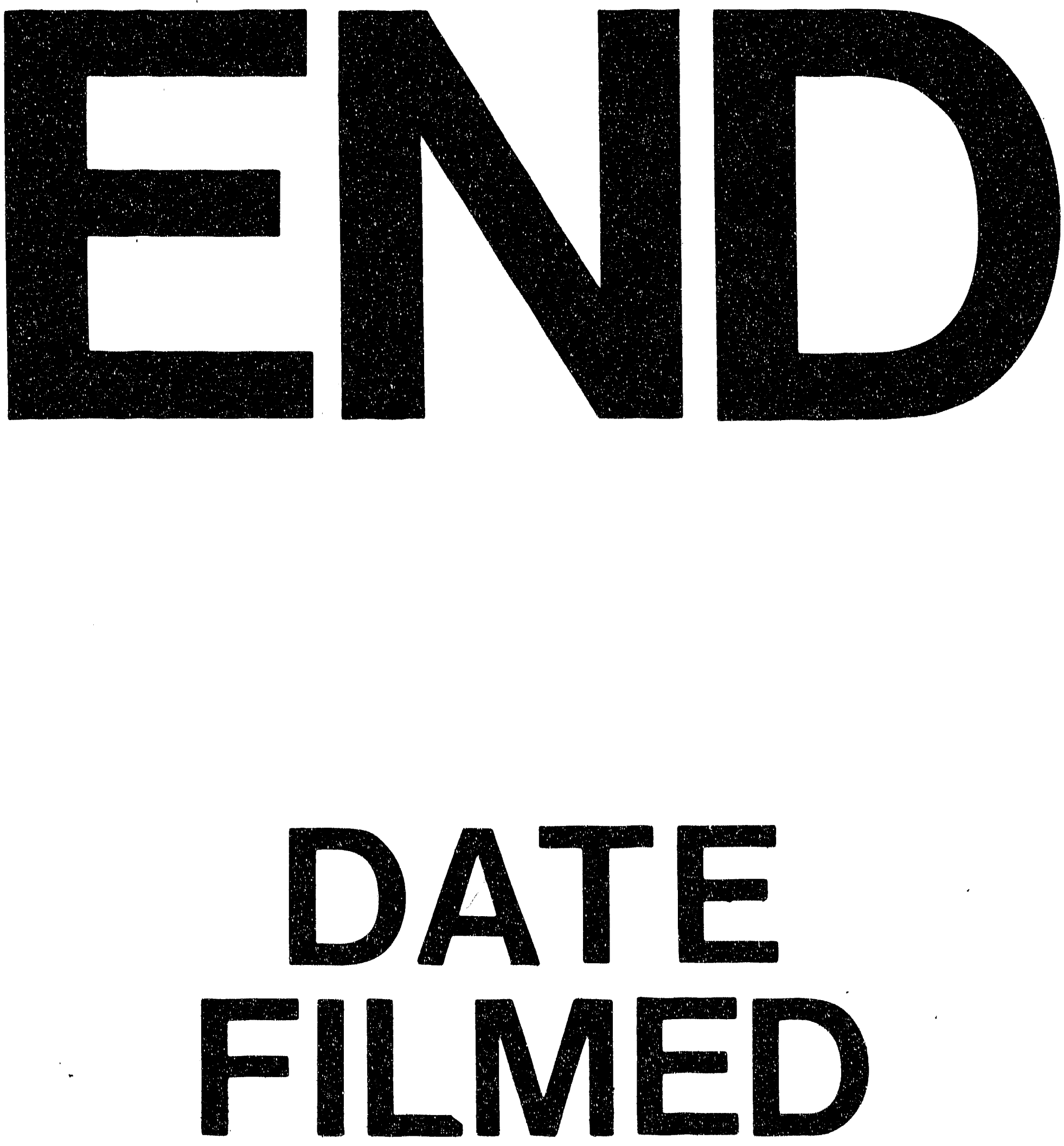

承

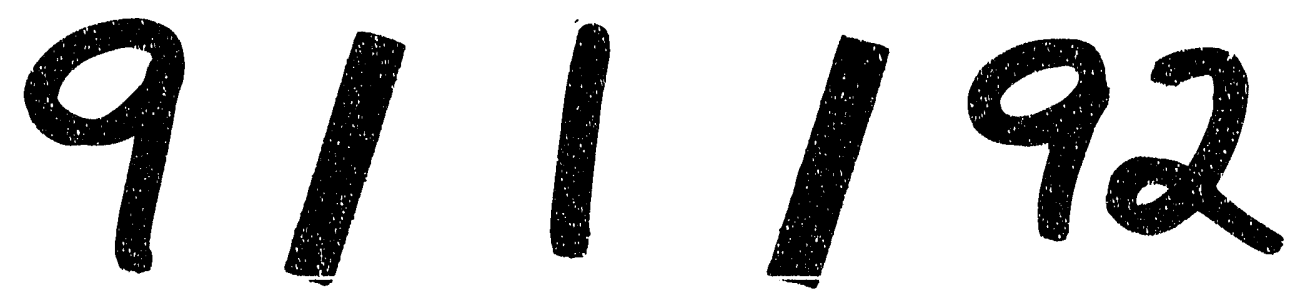


